$$
\text { UNIVERSIDADE DE SÃO PAULO }
$$

INSTITUTO DE FÍSICA, INSTITUTO DE QUÍMICA, INSTITUTO DE BIOCIÊNCIAS, FACULDADE DE EDUCAÇÃO

SAMUEL DA SILVA NUNES PAIVA

\title{
Competências:
}

\section{significados para o ensino de Física}




\title{
Competências:
}

\section{significados para o ensino de Física}

\author{
Versão corrigida
}

Dissertação apresentada ao Instituto de Física, ao Instituto de Química, ao Instituto de Biociências e à Faculdade de Educação da Universidade de São Paulo para obtenção do título de Mestre em Ensino de Ciências pelo Programa de Pós-graduação Interunidades.

Área de Concentração:

Ensino de Física

Orientadora:

Prof. Dra. Maria Regina Dubeux Kawamura

\section{São Paulo}

2018

Autorizo a reprodução e divulgação total ou parcial deste trabalho, por qualquer meio convencional ou eletrônico, para fins de estudo e pesquisa, desde que citada a fonte. 


\section{FICHA CATALOGRÁFICA}

\section{Preparada pelo Serviço de Biblioteca e Informação} do Instituto de Física da Universidade de São Paulo

\footnotetext{
Paiva, Samuel da Silva Nunes 2018.

Competências: significados para o ensino da física. São Paulo,

Dissertação (Mestrado) - Universidade de São Paulo. Faculdade de Educação, Instituto de Física, Instituto de Química e Instituto de Biociências.

Orientador: Profa. Dra. Maria Regina Dubeux Kawamura.

Área de Concentração: Ensino de Física.

Unitermos: 1. Física - Estudo e ensino; 2. Competência em ensino; 3. Ensino médio; 4. Currículo de ensino médio. 
Dedico este trabalho a minha amada Juliana, que em tudo me apoiou. 


\section{AGRADECIMENTOS}

Este trabalho não poderia ser concluído sem a colaboração de diversas pessoas.

Primeiramente, gostaria de agradecer a minha orientadora, Maria Regina Dubeux Kawamura, pelos ensinamentos preciosos e pela paciência aparentemente infinita para me ajudar a superar os desafios. Agradeço também a todos os professores e professoras que fizeram parte de minha formação, inspirando e ensinando.

Agradeço a minha família e amigos de maneira geral, por promover momentos de alivio com boa conversa e bom vinho.

Agradeço a população do estado de São Paulo que por meio do Instituto de Física da Universidade de São Paulo tornaram possível o desenvolvimento desse trabalho.

Agradeço a minha mãe que apesar das lutas e da dureza da vida, me criou em um ambiente seguro e de amor. Me apoio e suportou ao longo da caminhada para que qualquer conquista pudesse ter sido possível. E a meu pai, que com seu jeito quieto e todas as suas limitações, me proporcionou uma boa infância com muito mais do que ele próprio pode ter.

Agradeço de forma especial a minha esposa, Juliana, pelo apoio e encorajamento para seguir em frente. E ao meu filho, João, pelos sorrisos sinceros com que me recebe.

Por fim, agradeço a Deus e ao Senhor Jesus pela minha existência, pelo meu sustento e pela trajetória que até aqui me trouxe. 


\section{RESUMO}

PAIVA, Samuel S. N. Competências: significados para o ensino de Física. 2018. 197 f. Dissertação (Mestrado em Ensino de Ciências) - Instituto de Física, Instituto de Química, Instituto de Biociências e Faculdade de Educação, Universidade de São Paulo, São Paulo, 2018. Versão original.

As competências têm ocupado papel central em documentos que organizam o sistema de ensino brasileiro. Sua presença pode ser identificada em documentos oficiais, a partir de 1998, com a publicação dos Parâmetros Curriculares Nacionais e o início do Exame Nacional do Ensino Médio. Nas últimas décadas, muitos materiais, sequências didáticas e cursos de formação têm procurado incluir, referências às competências, ainda que em âmbitos e formas diferenciados. Nesse quadro, o objetivo desse trabalho é identificar os sentidos que vêm sendo atribuídos a esse termo, tanto de forma geral, como com especial atenção ao Ensino de Física. Para isso, e tomando como hipótese que a diversidade de compreensões incluem diferentes âmbitos de ações, investigamos a questão em três espaços de análise: (i) as construções teóricas de quatro autores reconhecidos por darem atenção ao tema, a saber Philippe Perrenoud, Philippe Jonnaert, Antoni Zabala e Laia Arnau; (ii) a presença do termo em documentos oficiais e em desdobramentos das políticas educacionais a eles relacionados, como por exemplo livros didáticos e no sistema de avaliação; (iii) a compreensão de professores em relação ao trabalho por competências. Em cada âmbito, foram utilizadas diferentes estratégias, incluindo análise de discursos teóricos, análise documental e análise de questionários respondidos por professores, fazendo uso, em diversos momentos, da Análise de Conteúdo. Buscando sistematizar, os diferentes sentidos que emergiram a partir da investigação, foi possível perceber como evoluem as compreensões das competências, respeitando diferentes propósitos e valores educacionais. Entendemos que o quadro resultante dessas análises pode, eventualmente, contribuir para uma maior apropriação, por parte dos professores no desenvolvimento de suas práticas, e uma conscientização dos elementos envolvidos em discussões críticas sobre o tema.

Palavras-chave: Competência em Ensino; Ensino Médio; Física; Currículo de Ensino Médio. 


\begin{abstract}
PAIVA, Samuel S. N. Competences: meanings for physics teaching. 2018. 197 f. Dissertation (Master in Science Education - Physics Education) Physics Institute, University of São Paulo, 2018. Original Version
\end{abstract}

The competences have played a central role in documents that organize the Brazilian education system. Their presence can be identified in official documents from 1998, with the publication of the National Curricular Parameters and the beginning of the National High School Examination. In the last decades, many materials, didactic sequences and training courses have tried to include references to the competences, in different ways and scopes though. In this context, the objective of this work is to identify the meanings that have been attributed to this term, both in general and with special attention to Physics Teaching. To this end, and assuming that the diversity of understandings include different scopes of action, we investigate the question in three spaces of analysis: (i) the theoretical constructions of three authors who are recognized experts: Philippe Perrenoud, Philippe Jonnaert and Antoni Zabala; (ii) the presence of the term in official documents and in the unfolding of educational policies related to them, such as textbooks and in the evaluation system; (iii) teachers' understanding of competency work. In each scope, different strategies were used, including analysis of theoretical discourses, documentary analysis and analysis of questionnaires answered by teachers, making use, at various times, of Content Analysis. In order to systematize the different senses that emerged from the investigation, it was possible to perceive how the understanding of competences evolves, respecting different purposes and educational values. We believe that the framework resulting from these analyzes may eventually contribute to a greater appropriation by teachers in the development of their practices and an awareness of the elements involved in critical discussions on the subject.

Keywords: Competence in Teaching; High school; Physical; High School Curriculum. 


\section{SUMÁRIO}

APRESENTAÇÃO

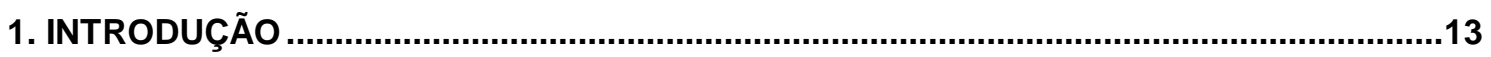

2. UMA APROXIMAÇÃO INICIAL AOS SENTIDOS DE COMPETÊNCIAS ….......................25

2.1. Competências em diferentes áreas do conhecimento ...............................................26

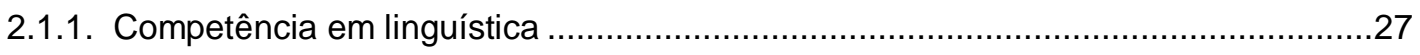

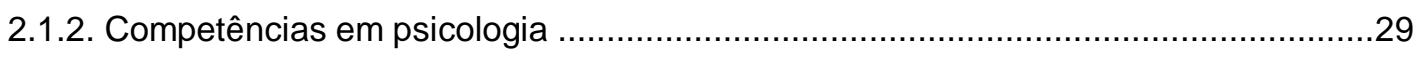

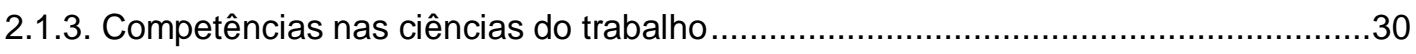

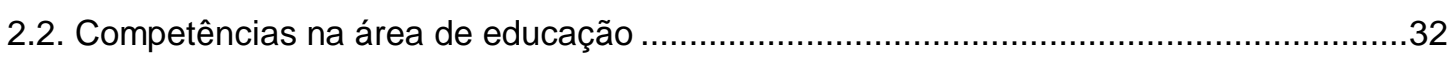

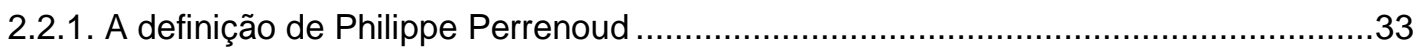

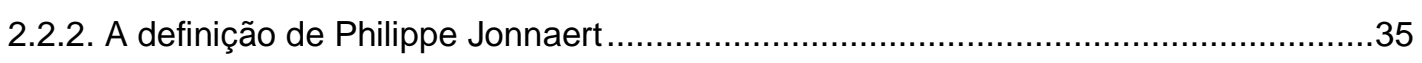

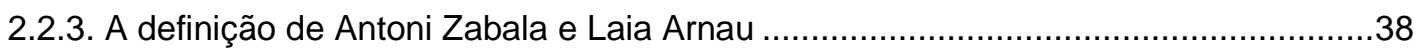

2.2.4. Comparando definições ............................................................................. 40

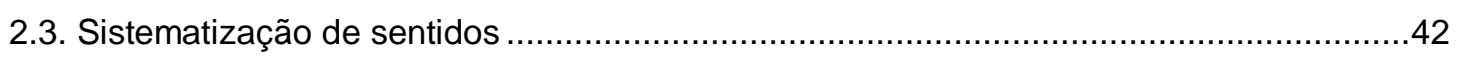

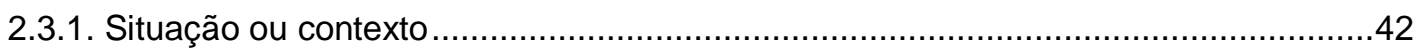

2.3.2. Transferência e Mobilização de recursos .............................................................46

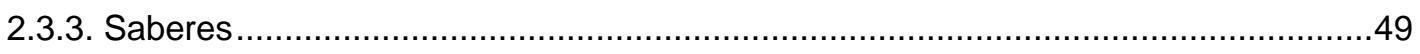

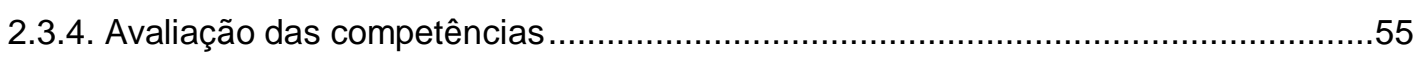

3. UMA VISÃO GERAL DE CURRÍCULO .......................................................................65

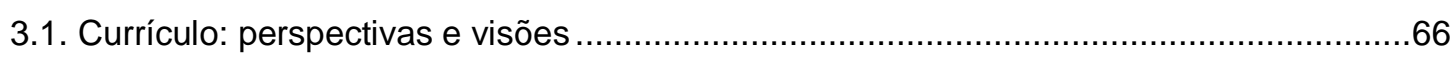

3.2. O currículo pode ser por competências? ..................................................................

4. AS COMPETÊNCIAS NOS DOCUMENTOS OFICIAIS ..................................................74

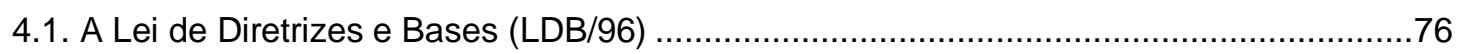

4.1.1. LDB/96: histórico e estrutura do documento ............................................................. 76

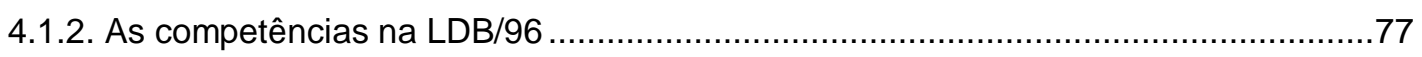

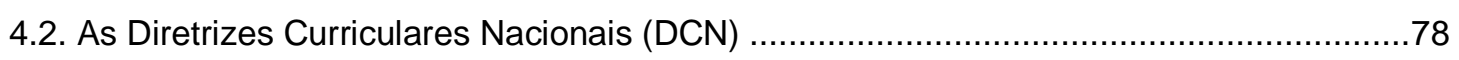

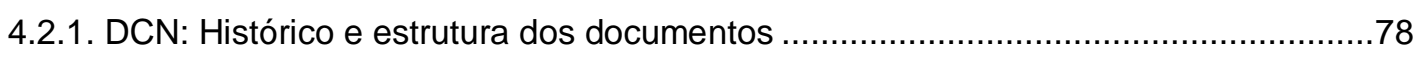

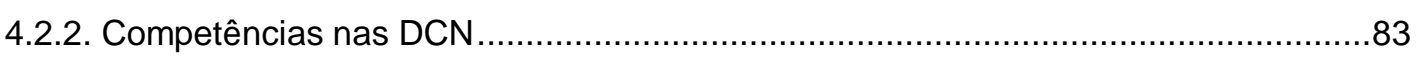

4.3. Os Parâmetros Curriculares Nacionais (PCN) e a Base Nacional Comum Curricular

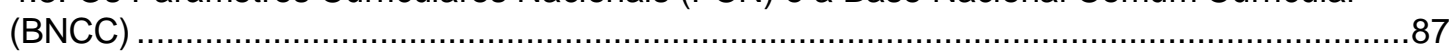

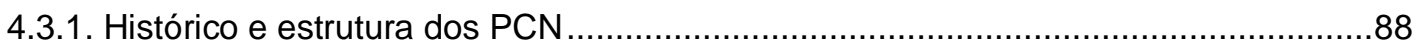

4.3.2. As competências na área de Ciências da Natureza e em Física ...............................89

4.3.3. A presença do conceito de competência nos PCN ...............................................94

4.3.4. Histórico, estrutura e competências na BNCC ...................................................96

5. Competências NO NÍVEL DE ORIENTAÇÃO DIDÁTICA …............................................101

5.1. O Programa Nacional do Livro Didático (PNLD) ................................................... 102

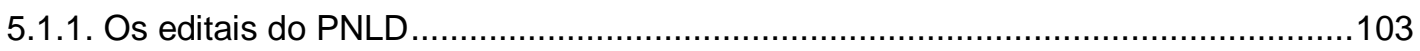

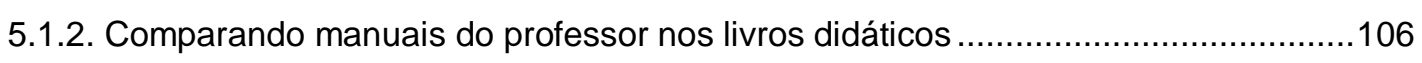

5.2. O Exame Nacional do Ensino Médio ..........................................................................111

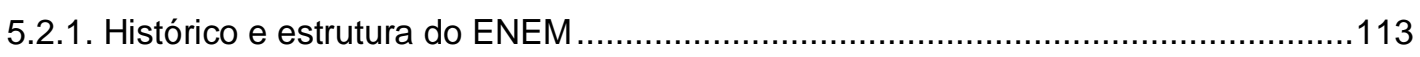

5.2.2. As competências na Fundamentação Teórico-Metodológica do ENEM...................115 


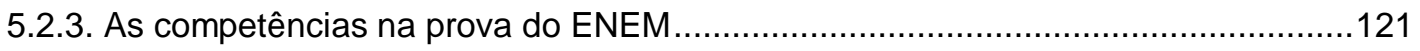

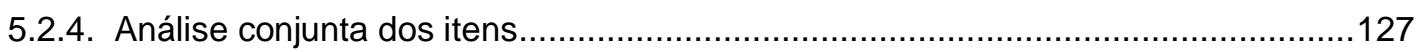

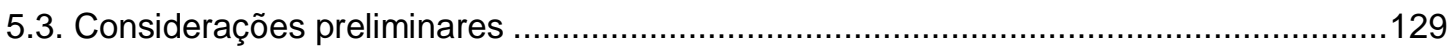

6. AS COMPETÊNCIAS NA VISÃO DE DOCENTES

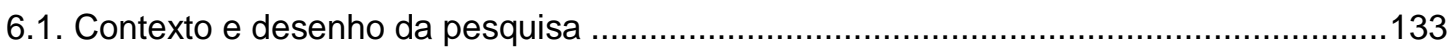

6.2. Matriz de análise: delimitando perfis dos professores e professoras.............................136

6.3. Considerações acerca das visões dos professores e professoras ...............................142

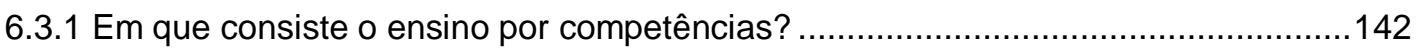

6.3.2. Sobre os objetivos do ensino tradicional e por competências.................................144

6.3.3. Sobre o contato em formação com o conceito de competência ................................146

6.3.4. Elementos da prática docente relacionados às competências................................147

6.4. Elementos de competências e a oposição ao ensino tradicional ...................................149

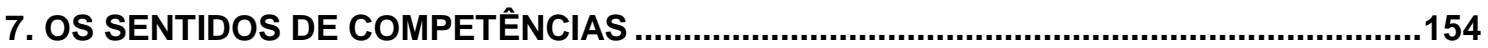

7.1. Os sentidos de competências e suas transformações ..................................................155

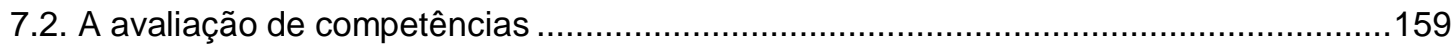

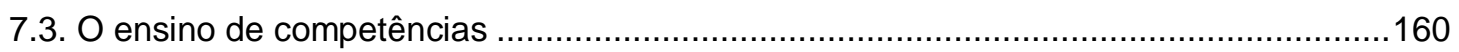

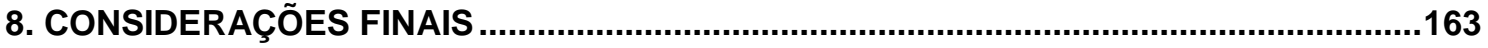

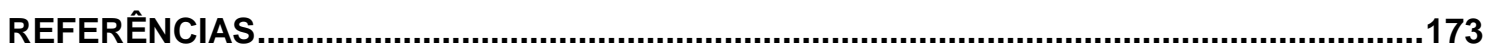

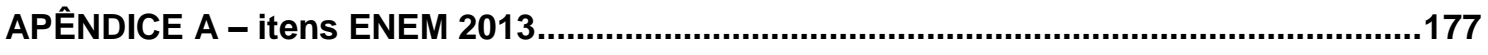

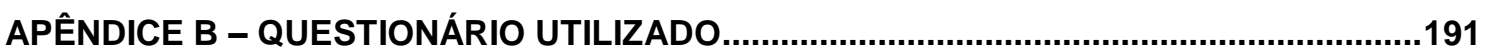

APÊNDICE C - TABULAÇÃO DAS PRINCIPAIS RESPOSTAS.........................................194 


\section{APRESENTAÇÃO}

Tendo ingressado no Curso de Licenciatura em Física, na Universidade de São Paulo no ano de 2009, e considerando as disciplinas cursadas por mim, não sou capaz de pensar em momentos nos quais tenha me deparado, dentro do curso, com os conceitos de habilidades e competências. Isso ocorreu muito embora estes conceitos tenham destaque nos Parâmetros Curriculares Nacionais para o Ensino Médio (PCNEM) e no Exame Nacional do Ensino Médio (ENEM), além de serem encontrados também em currículos de secretarias de Estados como o Currículo de Estado de São Paulo (CESP). É possível que estes conceitos tenham sido trabalhados ao longo do curso, mas sua relevância não ficou evidente para mim.

O contato mais marcante com os conceitos de habilidades e competências foi a partir do ano de 2013. Na oportunidade, trabalhei em uma plataforma de ensino online que se propunha a fornecer simulados do ENEM. O simulado deveria obedecer inclusive às regras de atribuição de pontos utilizando a Teoria de Resposta ao Item (TRI), também utilizada para a atribuição de pontos do ENEM. A matriz de competências e habilidades do ENEM deveria ser parâmetro para a revisão de itens que entrariam no simulado.

Além disso, a plataforma também se propunha a fornecer aulas que deveriam auxiliar os estudantes que apresentassem dificuldades especificas no simulado. Contudo, as aulas, à maneira como eram produzidas, organizadas e apresentadas não me pareciam condizentes com a maneira como o aluno era avaliado. $O$ início de uma pesquisa sobre os conceitos de competências e habilidades e a comparação entre, (i) a maneira como os conceitos eram apresentados na matriz do ENEM, (ii) o simulado aplicado e (iii) as aulas produzidas, levaram-me a questionar se havia coerência entre o que se 
avaliava e a maneira como o currículo da plataforma, e as próprias aulas, eram concebidos e organizados. A questão ampliou-se quando houve tentativa de compreender como os conceitos de habilidade e competência impactavam a organização do currículo de maneira perceptível em sala de aula. Em resumo, seria possível organizar o ensino a partir de um currículo por competências? Estaríamos ensinando as competências presentes nas matrizes de avaliação? Seria isso possível?

Em conversas com colegas professores, uma situação recorrente foi que muitos desconheciam ou desconsideravam os conceitos de competências e habilidades. Em muitos sentidos não era claro para os professores o que se esperava deles, quando era feita referência ao desenvolvimento de competências dos estudantes. Quais competências? $\mathrm{O}$ que eram competências? Que tipo de atividades ou que materiais poderiam auxiliar em seu desenvolvimento? Foram essas também outras questões que aumentaram minhas próprias inquietações.

Ao final do Curso de Licenciatura, em trabalho de final de curso (Paiva, 2014), optei, então, por uma análise entre a coerência do referencial teórico e os itens aplicados no ENEM, relacionando a presença das habilidades e competências.

Foram selecionados os itens da prova aplicada no ano de 2013. Em princípio foi feita uma discussão a respeito da fundamentação teórica do ENEM, como os conceitos de habilidade e competência eram abordados e como era utilizada a TRI na análise dos itens. Posteriormente, os itens foram analisados a partir de diversos critérios, dentre eles: tema, contexto, formulação, presença ou não de interdisciplinaridade e habilidade atendida. $A$ análise indicou que se apresentou uma distância considerável entre as dimensões de competências apresentadas na fundamentação teórica e aquelas que eram avaliadas. Esse trabalho nos encaminhou para o entendimento de que podem existir diversos sentidos para o que se entende por competência, e a falta de clareza sobre qual sentido se está adotando pode ser um dos fatores que provoca distância entre o que se estabelece em teoria e o que se pratica. Seria essa multiplicidade de sentidos um fator problemático, 
não só para o ENEM, mas também para documentos curriculares como os $\mathrm{PCN}$ ?

Essas preocupações motivaram o tema de interesse deste trabalho. Ou seja, investigar diferentes possibilidades de entendimentos para o conceito de competência, o que entendemos como dimensões básicas que caracterizam esse conceito e seus possíveis diferentes sentidos em referenciais teóricos, documentos oficiais da educação nacional e materiais que orientam práticas educacionais. A ideia é procurar esclarecer e auxiliar na identificação desses diferentes sentidos, de maneira a auxiliar a articulação entre teoria e prática. 


\section{INTRODUÇÃO}

Nos últimos anos o conceito de competência foi intensamente discutido, não só na área de educação, pois ao termo podem ser atribuídos diferentes sentidos, mas em diversas outras áreas de conhecimento. No web site do Dicionário Michaelis, por exemplo, são apresentadas sete definições para competências.

1- Aptidão que um indivíduo tem de opinar sobre um assunto e sobre o qual é versado.

2- [JURÍDICO] Legitimação de uma autoridade pública de julgar certos pleitos.

3- [JURÍDICO] Legitimação conferida a um indivíduo de atuar em seu próprio benefício.

4- Conjunto de conhecimentos.

5- [LINGUAGEM FIG.] Indivíduo com profundo conhecimento de determinado assunto.

6- Afluência de pessoas para ocupar o mesmo cargo.

7- [LINGUÍSTICA] Conhecimento linguístico inconsciente que torna um indivíduo capaz de compreender e construir um número infinito de frases em sua língua, mesmo aquelas nunca ouvidas; gramática internalizada, gramática mentalizada.

(Disponível em: michaelis.uol.com.br. Acessado em: 06 Ago 2016.) 
No site do Tribunal de Contas da União (TCU), são listadas as competências relacionadas a esse órgão público, sendo atribuído ali ao termo, um sentido de função ou jurisdição que limita sua ação.

De acordo com Jonnaert (2009), a noção de competências pode ser associada à linguagem em Chomsky, à psicologia do desenvolvimento em Nguyen-Xuan, à ciência do trabalho em Tanguy, ou à educação em Perrenoud. Além disso sua introdução e desenvolvimento podem ser relacionados a momentos e locais distintos, dependendo de qual área de conhecimento se analisa. Em linguagens, por exemplo, o conceito havia sido definido no início do século XX. No mundo do trabalho, começa a ser utilizado a partir da década de 1970 (DIAS, 2010).

Em educação não existe consenso sobre a origem do seu uso, mas no Brasil, no início dos anos 1990, o conceito de competência havia tomado força entre educadores e pesquisadores da área de educação. Em 1996, a promulgação da Lei de Diretrizes e Bases (LDB/96 $\left.{ }^{1}\right)$, abriu espaço para uma reformulação do sistema educacional brasileiro, ampliando a oferta de ensino e estabelecendo deveres e direitos relacionados à educação. Mas é a partir de 1998, que as Diretrizes Curriculares Nacionais de 1998 (DCN-1998), os Parâmetros Curriculares Nacionais (PCN) e o Exame Nacional do Ensino Médio $(E N E M)^{2}$, iniciam a estruturação do que se apresentou na LDB/96, e nesse contexto, o conceito de competência é evidenciado como estruturador de diretrizes, propostas curriculares, avaliações, materiais didáticos e como direcionador da prática na educação básica nacional, ganhando ainda mais destaque na matriz de referência para a avaliação no ENEM.

Esse contexto faz das competências uma temática de grande importância para pesquisadores na área de educação, sem, contudo, negligenciar a importância do conceito em outras áreas. Nessa perspectiva, diversos autores têm apresentado pesquisas, artigos e discussões a respeito do tema.

${ }^{1}$ Quando a referência ao documento for nossa, utilizaremos a nomenclatura LDB/96

${ }^{2}$ O ENEM possui duas fases distintas. A primeira, que vai de 1998 até 2008 , e a segunda, a partir de 2009, quando o exame passa a ser conhecido como novo ENEM. O Conceito de competências está presente em ambas as fases do exame. 
$\mathrm{Na}$ área de pesquisa em Ensino de Ciências podemos tomar o exemplo de Silva (2010), que se propõe a discutir o conceito de competência em sua relação com os conteúdos na escola básica. A autora faz uma crítica a fragmentação disciplinar encontrada atualmente no ensino e apresenta 0 conceito de competência como uma possível ferramenta para organizar o currículo gerando a superação desta fragmentação.

A autora aborda os documentos curriculares citados, fazendo uma comparação entre a LDB/96 e os PCN de cada um dos três níveis de ensino básico; infantil, fundamental e médio, e apresenta como indícios de emergência para adoção do conceito de competência o que é encontrado nos parâmetros de cada nível de ensino em consonância com o que está posto na LDB/96. Dessa forma, o currículo atual apresenta, segundo ela, uma organização do conhecimento fragmentada, mas a ideia de competência presente nos parâmetros, que é convergente com o que está posto na LDB/96, exige uma educação pensada de forma mais global e que integre as diversas disciplinas.

Além disso, a autora apresenta o ENEM como "um marco determinante na utilização da ideia de competência" (SILVA, 2010, p. 37), como exame que foi criado para atender às demandas postas na LDB/96. O texto discute, também, os objetivos do ENEM e como os conceitos de competências e habilidades são valorizados nesse exame.

De forma geral, Silva (2010) indica que pretende destacar a tensão existente entre a ideia de um currículo centrado na divisão de disciplinas, e um currículo com foco em desenvolvimento de competências. A autora apresenta como questões centrais: $O$ que trabalhar na escola: disciplinas ou competências? Qual a relação entre 0 ensino das disciplinas e 0 desenvolvimento de competências no aluno? (SILVA, 2010, p. 16). Um dos argumentos contra o uso das competências (RICARDO, 2005) é a possibilidade de se abandonar o pensamento disciplinar, caso a organização do currículo se de com base nas competências. Ou seja, há uma questão de discussão importante na área, sobre como devem se relacionar as competências com os conhecimentos disciplinares.

Ainda na área de educação, Briccia e Carvalho (2012) ao analisarem a formação continuada de um grupo de professores observam quais 
competências estão presentes em práticas com resultados positivos. As autoras, com base em referenciais de teóricos das competências, categorizam as competências que julgam relevantes na prática docente e analisam 0 processo de formação de modo a tentar identificar a presença das competências. É interessante notar que as autoras listam competências para os diversos momentos de desenvolvimento de uma atividade pelos professores. Assim, são assinaladas competências desde o momento de preparação da atividade até a interação com a equipe escolar e com os estudantes, mostrando que o conceito, desde que definido de maneira adequada, possui uma multiplicidade de aplicações.

Reconhecer essa multiplicidade de definições e aplicações possibilita que sejam encontrados trabalhos que investigam as competências a partir de outras áreas de conhecimento. Fleury e Fleury (2001), por exemplo, discutem o desenvolvimento de competências no contexto do mundo corporativo. $O$ artigo discute, de maneira resumida, diferentes sentidos que podem ser atribuídos às competências. O texto critica sentidos que associam as competências a um entendimento taylorista de organização do trabalho, esclarecendo que o "modelo taylorista não atende às demandas de uma organização complexa, mutável em um mundo globalizado" (FLEURY e FLEURY, 2001, p. 185).

$\mathrm{O}$ artigo também discute os múltiplos eixos envolvidos na formação de uma competência; a pessoa, sua formação educacional e sua experiência profissional estão envolvidas no desenvolvimento de uma competência. Para os autores, uma preocupação é a dúvida sobre como desenvolver essas competências profissionais no processo de formação profissional.

Sendo uma temática de tanta importância, as competências suscitam também diversas críticas. Na década de 1990, a adoção cada vez mais efetiva do conceito gerou também um número cada vez maior de críticas.

Embora Fleury e Fleury (2001), especificamente, critiquem o modelo taylorista de trabalho, associar esse modelo ao conceito de competências não só é possível, como é recorrente dentre aquelas críticas feitas ao conceito.

Ricardo (2005) apresenta o conceito de competências e uma extensa crítica sobre seu uso em educação. No texto, são apresentadas as caracterizações de competência e de qualificação, diferenciando e mostrando 
como as competências possuem um caráter mais amplo de formação e de exercício no trabalho. As críticas apresentadas relacionam as competências diretamente ao mundo do trabalho, apresentando autores como Ropé e Tanguy (1997), Ramos (2001) e Arruda (2000). O autor observa que "as críticas em relação à noção de competência vêm predominantemente da sociologia do trabalho e, em menor escala, dos estudos sobre currículo e da psicologia cognitiva" (RICARDO, 2005, p. 137).

Essas críticas são, portanto, em geral, relacionadas àquelas competências ligadas ao mundo do trabalho e à formação profissional, como expressão de uma lógica neoliberal de controle e negação de autonomia ao trabalhador, promoção da individualidade e do pensamento meramente pragmático (RICARDO, 2005).

Contudo, o próprio autor destaca que o mundo do trabalho, e a educação técnico-profissional, possuem características específicas, o que requer cuidado ao se transpor as críticas relacionadas às competências associadas a outros campos, como o da educação geral por exemplo. Sobre esse ponto, Jonnaert (2009) também chama atenção ao apresentar diferentes sentidos de competências, em diferentes campos de conhecimento e que são de difícil transposição para a educação geral (JONNAERT, 2009).

Embora nos últimos anos o conceito de competência tenha sido cada vez mais presente para o desenvolvimento de currículos e programas de ensino no Brasil, cabe investigar se a transição de uma lógica curricular centrada em conteúdos para uma lógica por competência, necessariamente propiciou uma mudança de prática em sala de maneira generalizada. De qualquer maneira, tal transição permitiu mudanças pontuais e fomentou 0 debate a respeito das competências.

Entre o final dos anos de 1990 e a década seguinte, muitos trabalhos relacionados ao Ensino de Ciências discutiram a adoção do conceito de competências em currículos. Silva (2008), por exemplo, trabalha a perspectiva de Perrenoud, e argumenta que segundo este autor, adotar nas práticas pedagógicas a lógica de competências implicaria em uma mudança radical na escola. Após desenvolver o pensamento de Perrenoud a respeito das competências, a autora levanta os possíveis problemas de se formular um 
currículo por competências, concluindo que "a definição de uma lista de competências para a escola básica conduz ao risco de se proceder a generalizações e tornar as competências tão abstratas que iriam distanciandose cada vez mais [...] do sentido que Ihes deram origem" (SILVA, 2008, p. 94).

Portanto para Perrenoud, de acordo com Silva, organizar um currículo com base em uma lista de competências, que devem ser desenvolvidas, alcançadas e avaliadas, não é o tipo de ação da qual se espera resultados compatíveis com uma educação que obedeça à lógica das competências. Isso evidencia a diferença entre o uso do termo "competência" e uma organização de fato, com base em competências.

Jonnaert et al. (2010) também destacam que, embora se discuta a relação entre competências e currículo ou a adoção de um currículo orientado por competências:

É útil lembrar, no entanto, [...] que a noção de competência continua sendo, apesar de tudo, um objeto muito pouco curricular. Essa noção tende mais a orientar a ação dos alunos em sala de aula do que permitir identificar de modo eficaz o que está prescrito nos programas de ensino. (JONNAERT, et al. 2010, p. 68).

Um dos principais proponentes da lógica das competências em ensino, Philippe Perrenoud, reconhece que os sentidos que se pode atribuir às competências são múltiplos (PERRENOUD, 1999). Jonnaert et al. (2010), novamente, reforçam essa característica das competências argumentando que elas possuem diferentes abordagens em função dos campos disciplinares onde são usadas (JONNAERT, et al. 2010).

É possível perceber a presença das competências em diferentes áreas de conhecimento e em diferentes níveis de discussão. Seria possível transferir o uso deste conceito entre essas diferentes áreas e diferentes níveis sem considerar alterações no seu entendimento em cada um desses contextos? Se esta dificuldade se verificar, existe o risco de que sejam geradas contradições? A existência de diferentes entendimentos, e algumas contradições na tentativa de adoção das competências, tornaria necessária a pergunta sobre qual é o sentido atribuído às competências em cada situação. 
Para Lopes (2008), por exemplo, currículos que obedecem à lógica de competências possuem um caráter integrador, mas carecem de uma perspectiva crítica na educação, uma vez que propõe uma formação que atende às necessidades de mercado e que promovem a manutenção da ordem social vigente, à qual, o estudante, desenvolvendo as competências necessárias, deve, sem contestação adaptar-se. É importante, no entanto, que se esclareça a qual competência a autora se refere, se àquela defendida por Perrenoud e Jonnaert, ou à apresentada nos PCN e no referencial teórico do ENEM, ou, ainda, à que comparece na aplicação dos testes em escala, nos materiais didáticos, na prática de sala de aula ou até às competências associadas a outros campos disciplinares como psicologia, ciência do trabalho, linguística etc.

É a partir da perspectiva que considera essa possível multiplicidade de sentidos que se pode atribuir ao conceito de competências que se desenvolverá este trabalho. Diante disso, o que se propõe investigar como questão central é: como se mantêm ou são alterados os sentidos atribuídos às competências quando se investiga seus sentidos em níveis de diferentes abrangências no campo da educação? Além disso, procuraremos investigar se existem elementos básicos que constituem e caracterizam uma competência em diferentes instâncias.

As competências são de grande importância em diversos campos de conhecimento, mas com exceção de uma rápida abordagem diversificada no capítulo 2, o foco da investigação deste trabalho será a área de ensino, com um interesse mais específico no Ensino de Física.

O objetivo deste trabalho é, portanto, investigar se há alterações nos sentidos das competências, na medida em que o conceito é utilizado em diferentes âmbitos e níveis de abrangência, desde sua estruturação teórica até sua presença no discurso de professores e professoras em sala de aula. Procuraremos também identificar em que consistem essas alterações, se houverem.

Tais análises implicam em mudanças de níveis de abrangência. Ou seja, passaremos da investigação sobre os sentidos das competências no Nível Teórico, mais abrangente e que não possui compromisso com um 
sistema de educação específico, para uma investigação menos abrangente no Nível de Regulamentação, que se refere a documentos oficiais, que dizem respeito ao sistema de educação brasileira. Esses documentos, dentre outras funções, orientam a elaboração de diversos materiais, inclusive livros didáticos. Cada livro didático possui uma abrangência ainda menor do que os documentos, pois dentro do sistema educacional brasileiro, diversos livros são disponibilizados para cada disciplina, e selecionados de acordo com as características e preferências da escola e do professor ou professora responsável. Ao nível de abrangência dos manuais didáticos nos referiremos como Nível de Orientação Didática.

Por fim, procuraremos investigar como os desdobramentos dos sentidos das competências chegam aos professores e professoras na sua atuação, ou ao menos, em sua perspectiva pedagógica a respeito das competências, a que nos referiremos como Nível de Aplicação.

A perspectiva de cada professor é talvez o nível de menor abrangência se observado isoladamente, mas entendemos que é neste nível em que a aplicação dos sentidos das competências se dará de fato, embora orientada pelos níveis anteriores. Às diferentes compreensões quanto aos sentidos das competências quando comparados entre diferentes níveis de abrangência, denominaremos comparação Vertical de sentidos.

Mas em um mesmo nível de aplicação, pode ser possível perceber diferenças. Ao serem comparadas as definições de teóricos sobre os sentidos atribuídos às competências, é possível identificar diferentes ênfases e percepções de cada um. Da mesma forma, materiais didáticos diferentes podem apresentar diferentes entendimentos com relação aos sentidos das competências em sua elaboração e ainda mais professores e professoras podem apresentar visões particulares a respeito dos sentidos das competências. Aos diferentes sentidos atribuídos ao conceito quando se comparam diferentes fontes em um mesmo nível, denominaremos comparação Horizontal de sentidos. 
Figura 1.1- Níveis de investigação presentes no trabalho.

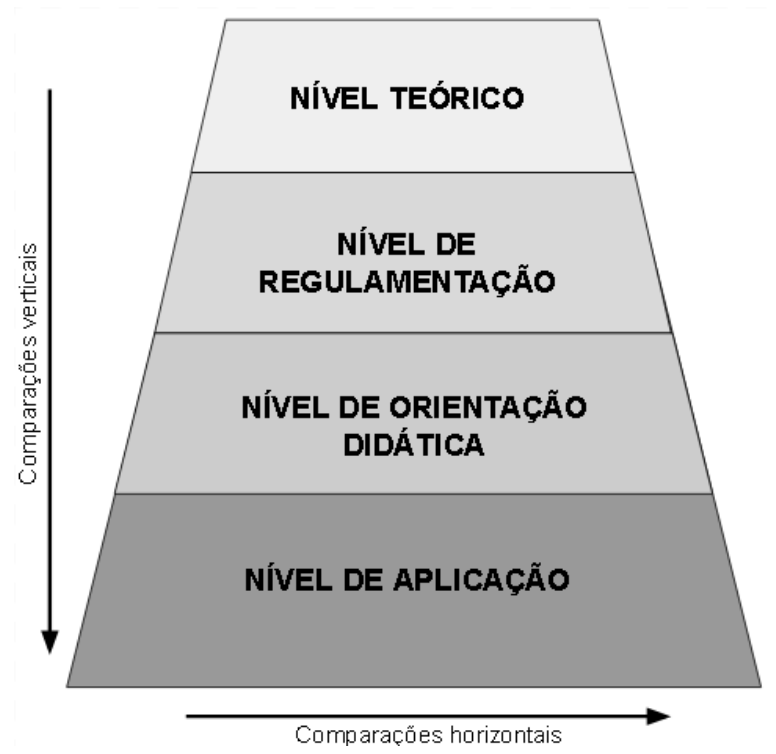

Fonte: Elaborado pelo autor.

A estrutura do trabalho procurará seguir o que se apresenta na figura anterior. Em relação às competências, a discussão será iniciada no nível teórico. A cada capítulo pretende-se uma "mudança de nível" a ser investigado em um "movimento vertical".

A estratégia adotada para esta investigação foi a de análise direta dos sentidos atribuídos às competências nos diferentes níveis e âmbitos em que o conceito é abordado. Para investigar a presença e os sentidos das competências nesses diferentes âmbitos, optou-se por uma análise documental, complementada pela Análise de Conteúdo ou pela Análise Textual Discursiva.

Nesse sentido, propomo-nos a buscar criar um conjunto de referências comuns sobre o termo, a partir das propostas de alguns educadores que se debruçaram sobre o assunto, e reconhecidos por suas contribuições sobre o tema, a quem nos referiremos como "teóricos".

Será feita uma primeira abordagem geral do conceito de competência a partir do trabalho de Jonnaert (2009) para caracterizar o conceito em diferentes âmbitos. Em seguida serão comparadas as definições de quatro teóricos, Philippe Perrenoud, Philippe Jonnaert, Antoni Zabala e Laia Arnau, a respeito das competências. 
Esses autores nos pareceram apresentar visões a respeito das competências, ao mesmo tempo, distintas e coerentes. Distintas porque, as diferentes trajetórias, contextos, nacionalidades e visões dos autores, Ihes conferem perspectivas próprias a respeito das competências, gerando algumas diferenças que podem contribuir para o enriquecimento do debate. Coerentes porque, de acordo com nosso julgamento, a despeito das diferenças, as visões desses autores apontam para um sentido razoavelmente comum.

Reconhecemos que existe um grande número de importantes trabalhos de investigação nos diferentes âmbitos que serão aqui abordados. Galian (2014), Macedo (2008) e Dias (2010) são exemplos de trabalhos que analisam as competências em documentos oficiais, além de discutir os sentidos assumidos pelo conceito nas políticas educacionais. No entanto, uma análise destes trabalhos exigiria que se considerasse o sentido de competência adotada por seus autores, isso porque, cada trabalho, ao apontar as competências em livros didáticos, ou as competências em provas do Enem, por exemplo, parte de perspectivas diferentes, que nem sempre serão comparáveis. Além disso, e sem desmerecer os resultados obtidos nesses trabalhos, a proposta se tornaria ampla demais.

Os elementos obtidos a partir dessa investigação serão então utilizados nas análises subsequentes.

Depois disso será apresentado o nível de regulamentação com os documentos oficiais de currículo, para o nível de orientação didática com os livros didáticos e o nível de aplicação considerando a visão de professores e professoras com relação às competências em sua prática docente. Em cada capítulo a intenção é fazer uma comparação "horizontal" de sentidos, isto é, nesse mesmo nível, em que medida há diferentes sentidos atribuídos às competências.

Foram também realizadas aproximações com 0 pensamento de professores. Para isso, utilizaram-se questionários, analisados a partir da Análise de Conteúdo (BARDIN, 2009)

A importância das competências se mostra pela sua ampla presença em diversos níveis do sistema de educação brasileira. Embora diversos autores façam análises em um mesmo nível de abrangência, nossa intenção é, além de 
uma investigação horizontal, procurar de maneira comparativa as mudanças de sentido das competências em diferentes níveis verticais. Procuraremos compreender como os sentidos do conceito se modificam, ou não, desde sua formulação teórica passando pelos desdobramentos regulatórios até sua presença em sala de aula. Esperamos que esta investigação possa trazer alguma iluminação às discussões a respeito das competências, enriquecendo as discussões sobre do tema que se tornam cada vez mais necessárias.

Dessa forma, o trabalho se organizará da seguinte maneira:

No capítulo 2 serão apresentados diferentes sentidos que podem ser atribuídos às competências no nível teórico. Comparando o sentido de competências em diferentes áreas de conhecimento, em seguida, comparando os sentidos de competências em educação segundo o trabalho de quatro autores.

No capítulo 3 , será apresentada uma visão geral sobre diferentes perspectivas curriculares e qual o lugar de um currículo organizado segundo a lógica de competências.

No capítulo 4 será feita a apresentação dos documentos curriculares brasileiros, em uma tentativa de compreender os diferentes sentidos de competências presentes nesses documentos, apresentando divergências e convergências que são percebidas com base na discussão do capítulo anterior.

No capítulo 5 será discutida a presença das competências e o sentidos a elas atribuídos no manual do professor de duas obras aprovadas para 0 Programa Nacional do Livro Didático (PNLD). Consideraremos também, como fazendo parte do Nível de Orientação Didática o ENEM. Procuraremos investigar os sentidos dados as competências tanto na fundamentação teóricometodológico do ENEM quanto nos itens do exame.

No capítulo 6 é apresentada a discussão a respeito da visão de professores e professoras com relação às competências. Foi elaborado um questionário sobre a relação dos professores com o conceito de competências, sua visão e prática. Professores e professoras responderam a este questionário e os resultados são ali discutidos.

No capítulo 7, serão por fim apresentadas considerações a respeito de dificuldades e pontos que merecem atenção na estruturação do conceito de 
competência. Também será apresentada uma reflexão sobre a necessidade de articulação de diferentes sentidos de competências em uma busca por maior coerência e efetividade de propostas supostamente organizadas por competências.

O capitulo 8 apresentará algumas problemáticas em relação às competências ou a conceitos correlatos. Por fim, serão também apresentadas algumas discussões finais a respeitos dos resultados encontrados. 


\section{UMA APROXIMAÇÃO INICIAL AOS SENTIDOS DE COMPETÊNCIAS}

O conceito de competência, embora seja, atualmente, relacionado à educação e a determinadas teorias de currículo, não é um conceito restrito a esta área do conhecimento, tão pouco se origina neste. Jonnaert (2009) apresenta o uso das competências em áreas como, psicologia, linguística, ciências do trabalho, sendo posteriormente assimiladas em educação.

Os sentidos que as competências podem admitir são tão distintos quanto as áreas em que o conceito é adotado. E em alguns casos, dentro de uma mesma área de conhecimento, as competências encontram definições diversas. Dessa forma, é razoável afirmar que "não existe uma definição clara e partilhada das competências" (PERRENOUD, 1999, p. 19). Embora não exista tal definição clara, e de maneira ampla, partilhada, é de grande importância que se compreenda as diferentes possibilidades de sentidos para as competências, e que se localize, dentro dessas possibilidades, aquela que é adotada na implantação de ações e práticas referentes às competências.

Em educação, por exemplo, a definição do sentido que se adota para as competências, é importante em ao menos dois aspectos. Em primeiro lugar, para garantir coerências entre definições teóricas e desenvolvimentos práticos, que podem facilmente cair em contradições se os entendimentos sobre os 
sentidos das competências não são claros. Em segundo lugar, para garantir a aplicabilidade de propostas e políticas públicas que perpassam diversos níveis de abrangência. Se os autores de documentos oficiais adotam um sentido para as competências, diferente daquele adotado por autores de materiais didáticos que por sua vez difere daquele adotado por professores, muitas propostas podem ser consideradas impossíveis de realizar, não necessariamente por uma real impossibilidade, mas por uma comunicação que não considera esses diferentes sentidos para as competências.

O objetivo deste capítulo é, com base no texto de Jonnaert (2009), apresentar diferentes sentidos para as competências em diferentes áreas de conhecimento. Depois disso apresentaremos os sentidos do conceito de competência no nível teórico a partir da obra de quatro autores: Philippe Perrenoud, Philippe Jonnaert, Antoni Zabala e Laia Arnau. Primeiramente serão discutidas as definições do termo de acordo com cada autor. Depois, apresentaremos, a discussão a respeito dos elementos: saber-fazer (savoir-fair), mobilização de recursos, situação e avaliação a partir de cada um dos autores.

\subsection{Competências em diferentes áreas do conhecimento}

Nesta seção apresentaremos o conceito de competências em diferentes áreas de conhecimento, a saber: linguística, psicologia, ciências do trabalho e educação. Existem, certamente, muitas outras áreas em que se pode analisar os sentidos de competências, contudo, entendemos que a apresentação das áreas citadas ilustram de maneira clara o caráter polissêmico das competências e a importância de entendê-las a partir de um contexto.

A apresentação feita aqui é encontrada no trabalho de Jonnaert (2009). Philippe Jonnaert é professor titular do departamento de matemática da Universidade de Quebéc em Montreal. É diretor do Centro Interdisciplinar de Investigações sobre a Aprendizagem e o Desenvolvimento em Educação (CIRADE) e do Observatório das Reformas em Educação (ORE), em Montreal. Jonnaert é também titular da Cátedra UNESCO em engenharia do curriculum na Universidade de Quebeque e lidera um programa que, com financiamento do Banco Mundial, tem trabalhado no sentido de reformular o currículo da Costa do Marfin. Este autor possui diversos títulos publicados em português 
sobre currículo, reforma curricular e especialmente sobre a relação entre currículo e competências. Entendemos que a abordagem de Jonnaert é ampla o bastante para fornecer uma visão panorâmica e substancial com relação ao conceito de competências e suas abordagens em diversas áreas do conhecimento.

Jonnaert (2009) apresenta o desenvolvimento do conceito de competência e seu sentido em diferentes áreas de conhecimento. $O$ autor coloca no início do século XX a utilização do conceito de competências pelos linguistas que as diferenciam claramente do conceito de desempenho, fazendo essa mesma comparação no campo da psicologia. No campo das ciências do trabalho, o autor faz uma nova comparação, que mostra uma evolução do conceito de qualificação até ser substituído pelas competências. Todas essas abordagens são então comparadas com o campo da educação e seu sentido próprio para as competências.

\subsubsection{Competência em linguística}

Para os linguistas, as competências são potencialidades individuais, aquilo que permite a um individuo de determinado grupo formular um número virtualmente infinito de frases, ou seja, tomando aquilo que os linguistas definiam como palavra, a partir de seus conhecimentos sobre a língua (JONNAERT, 2009). Dessa forma, a competência é implícita e individual, pois a capacidade ou potencialidade do individuo de comunicar-se esta relacionada à existência da competência, mas a comunicação efetiva, o tomar a palavra e transmitir ideias, relacionam-se com o desempenho, que é, por sua vez, de ordem social e inscrito em uma situação. A ação não é, portanto, condição para a existência da competência. O mapa conceitual a seguir apresenta de maneira esquemática a relação entre os conceitos de competência e desempenho para os linguistas. 
Figura 2.1- Mapa conceitual que relaciona os conceitos de Competência e Desempenho de acordo com o entendimento dos linguistas, mais especificamente, de acordo com o desenvolvimento proposto por Noam Chomsky.

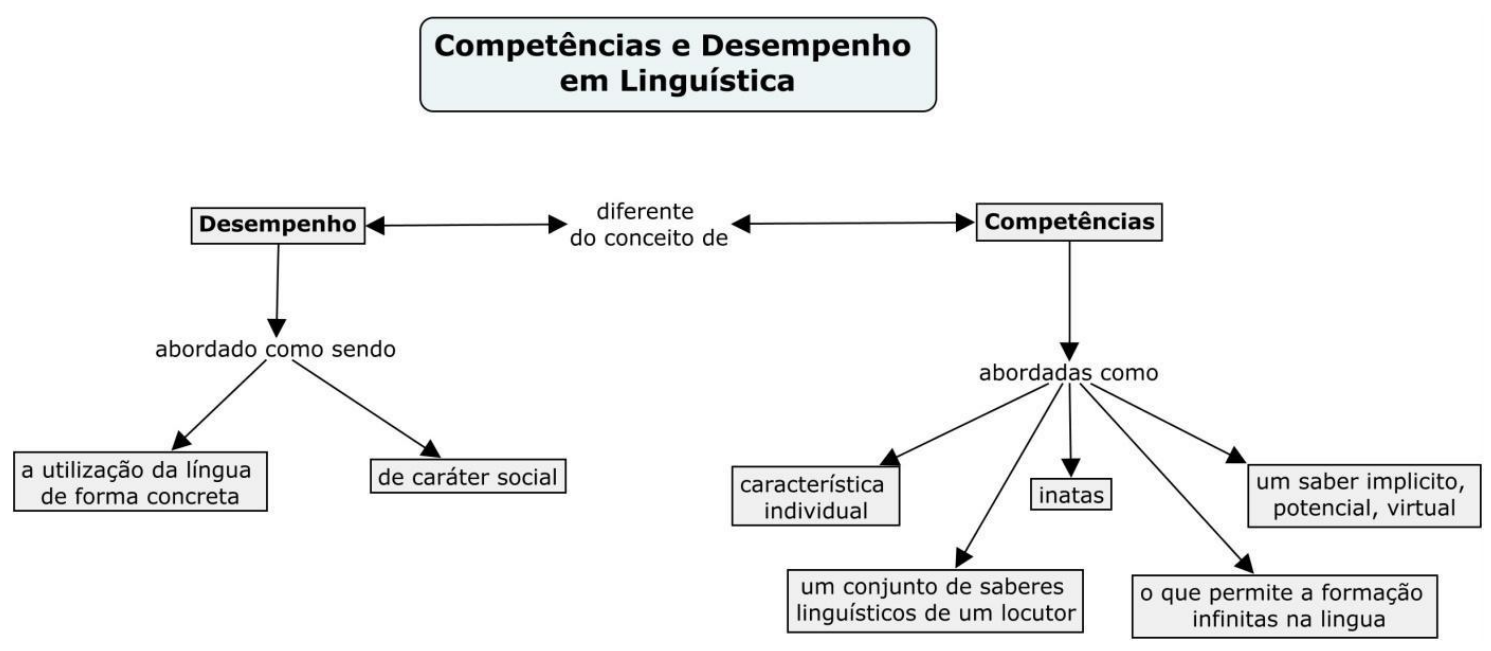

Fonte: Elaborado pelo Autor.

É interessante notar que, nesse sentido, o desempenho não é condição necessária para definir ou determinar a existência das competências, pois esta é entendida como uma potencialidade. $O$ desempenho por sua vez pressupõe a existência de uma competência, pois, se não existe competência, não existe potencialidade de ação e dessa maneira o desempenho não poderia ser observado.

Outro ponto que merece atenção e que pode expandir o debate é o caráter inato que os linguistas atribuem às competências. A potencialidade de articulação da palavra dependeria apenas de capacidades biológicas e mecânicas? Nesse caso a espécie humana poderia ser caracterizada pela presença de competências linguísticas? Contudo, o desenvolvimento da língua em um indivíduo depende do meio e dos estímulos sociais a que é submetido. O caso de Kaspar Hauser, e outros semelhantes, levanta a questão sobre se seria possível possuir competências linguísticas por razões biológicas? Ou elas não estavam nele presentes por conta da ausência de interações sociais e a despeito de sua estrutura biológica e motora (BLIKSTEIN, 2009)? 


\subsubsection{Competências em psicologia}

De acordo com Jonnaert, a psicologia possui também uma definição própria de competências. Nesta área de conhecimento, as competências são novamente distintas do conceito de desempenho, mas não da mesma forma que em linguística.

$\mathrm{Na}$ psicologia, as competências são critérios, fruto de modelos das respostas esperas de determinados indivíduos inscritos em certo grupo e que enfrentam o mesmo tipo de situação, ou de um mesmo indivíduo comparado consigo em situações diferentes, mas que obedecem a parâmetros de controle.

O desempenho por sua vez, é medido por meio de testes cujo resultado pode localizar o individuo em relação à competência. A análise da defasagem entre $\mathrm{o}$ desempenho $\mathrm{e}$ as competências esperadas determina 0 desenvolvimento cognitivo de um indivíduo. Contudo o desempenho de um grupo permite a atualização das competências definidas a priori. O mapa conceitual a seguir procura comparar e relacionar os conceitos de competência e desempenho de acordo com o entendimento dos psicólogos.

Figura 2.2- Mapa conceitual que relaciona os conceitos de Competência e Desempenho de acordo com o entendimento dos psicólogos.

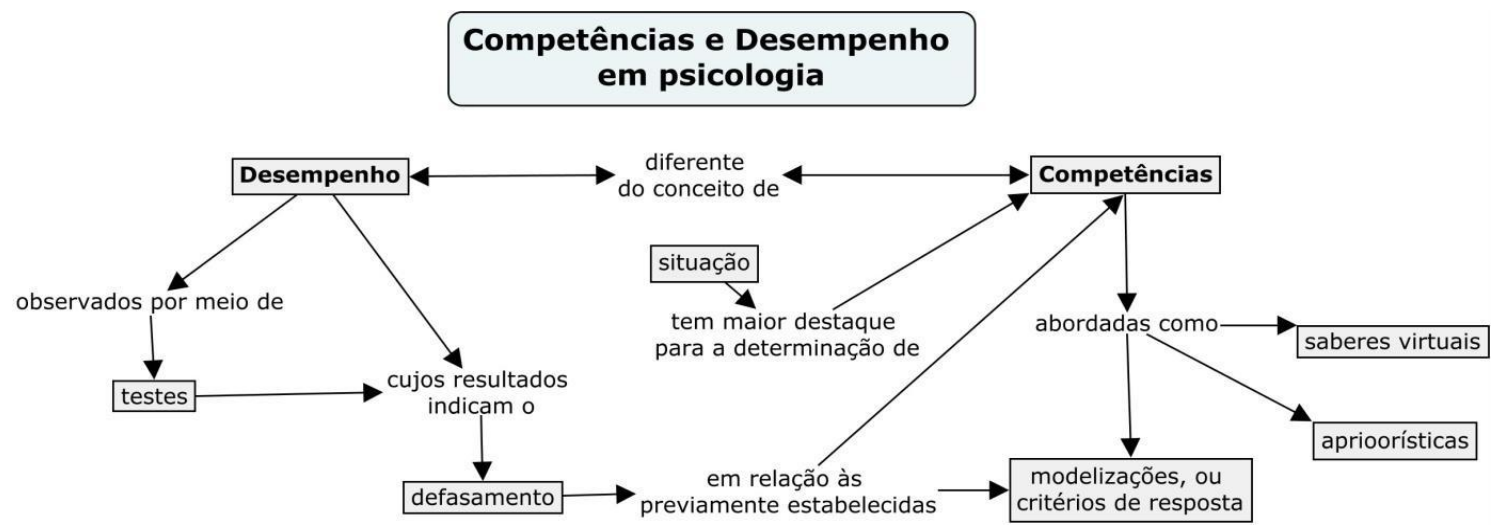

Fonte: Elaborado pelo Autor.

A comparação entre o entendimento de competência para os linguistas e para os psicólogos permite observar como o mesmo conceito pode possuir pontos de intersecção e de importante distanciamento entre diferentes áreas. Em ambos os casos, as competências são virtuais, e o desempenho são 
efetivos. Mas enquanto para os linguistas a competência é uma característica interna, que pertence ao indivíduo, e potencial, portanto que independe do desempenho, para os psicólogos a competência é uma característica externa, que parametriza o individuo e é atualizada pelos resultados do desempenho.

\subsubsection{Competências nas ciências ${ }^{3}$ do trabalho}

As competências também aparecem no âmbito das ciências do trabalho, o sentido a elas atribuído nessa área de conhecimento é constantemente utilizado como referência para as críticas direcionadas ao conceito quando tratado no campo da educação.

O conceito que se contrapõe as competências nas ciências do trabalho é o conceito de qualificação. Embora se entenda que as competências sejam resultado de uma evolução com respeito às ideias de qualificação, a diferença entre os conceitos é claramente estabelecida por Jonnaert (2009).

A qualificação está bastante relacionada com uma visão instrumentalista. É possível compreendê-la como um conjunto de conhecimentos e características, a priori adquirido pelo indivíduo em seu processo de formação. É interessante notar que o desenvolvimento da qualificação acontece em situações que não necessariamente se relacionam com aquelas que serão enfrentadas na realidade do trabalho (JONNAERT, 2009). É possível fazer essa comparação com relação à função de docência, pensando nesta como uma função inserida no contexto do trabalho. Um estudante de licenciatura, ao final de seu curso está apto, ou qualificado para assumir o cargo de professor em uma escola. Ele possui o diploma, que certifica os conhecimentos necessários para o exercício de tal função. Este aluno pode inclusive, conhecer diversas técnicas a respeito de como elaborar um plano de aula coerente para o ensino, mas é possível que chegue a sala sem conhecer o procedimento de preenchimento de um diário de sala, ou sem ter desenvolvido técnicas de oratória.

${ }^{3}$ Embora pareça um uso estranho para o leitor de fala portuguesa, o termo "ciências do trabalho" é utilizado pelo autor na versão em português do texto analisado, e por isso é apresentado dessa maneira neste trabalho. 
Dessa forma, a qualificação pode ser definida como este conjunto de qualidades pré-observadas no indivíduo e que o tornam oficialmente apto para a realização de uma tarefa.

A competência, em contrapartida, exige uma análise da ação do indivíduo face a uma determinada situação. A competência é, portanto, de caráter relativista, pois é definida com base na situação e em como esta é enfrentada. Dessa forma a ideia de competência aqui, valoriza a autonomia do indivíduo nas tomadas de decisão que influenciam na situação. Vê-se novamente um destaque para a situação no sentido em que a competência se exprime na relação existente entre a tarefa e o potencial de realização por parte do indivíduo, entre os conhecimentos adquiridos e sua capacidade de articular tais conhecimentos resultando em uma ação eficiente. O próprio conceito de ação toma um importante lugar nessa concepção, e que não se observa no conceito de qualificação, uma vez que a ação, ao mesmo tempo em que permite ao indivíduo influenciar a situação de modo eficaz, deve permitir também uma reflexão que transcenda seus gestos e os processos executados. O mapa conceitual a seguir apresenta de maneira esquemática a diferença entre os conceitos de qualificação e competência.

Figura 2.3- Mapa conceitual que relaciona os conceitos de Competência e Qualificação no mundo do trabalho.

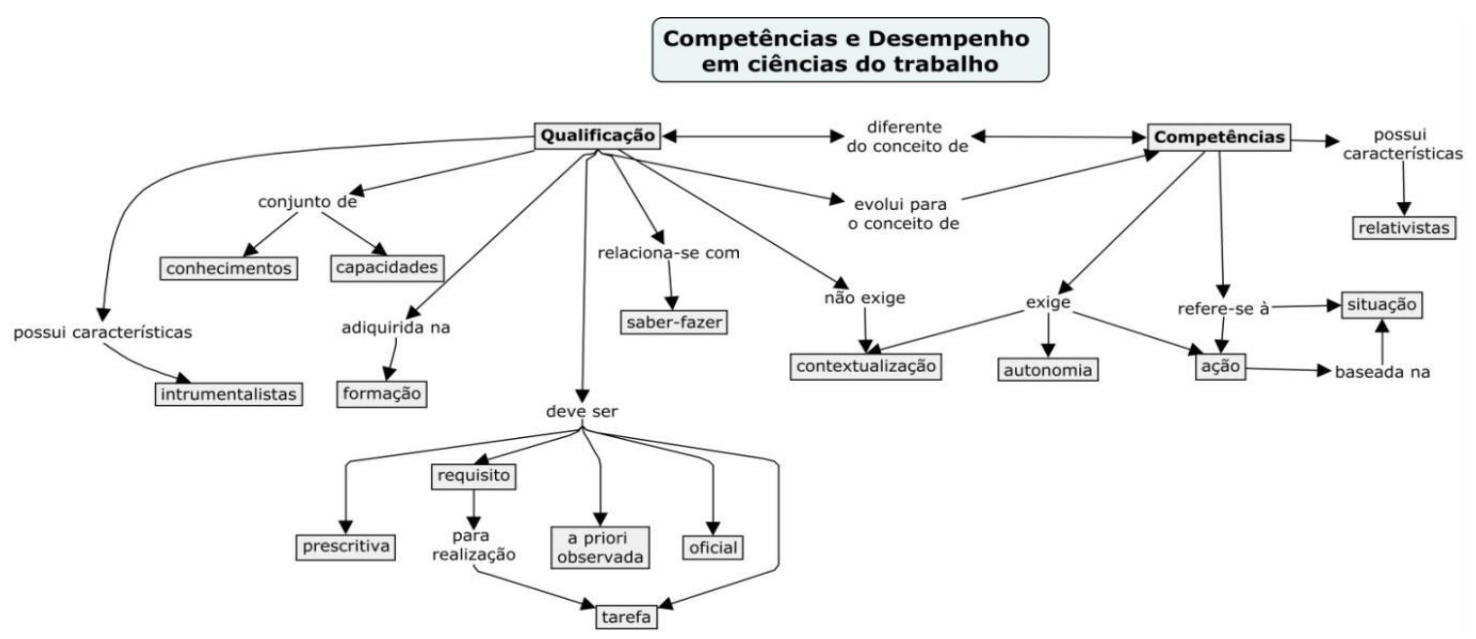

Fonte: Elaborado pelo Autor. 


\subsection{Competências na área de educação}

Jonnaert (2009) admite a dificuldade que existe em se transpor o conceito de competência dessas diversas áreas para o campo da educação. As áreas de conhecimento possuem especificidades capazes de tornar quase exclusivos determinados aspectos do sentido de competência ali assumido, dessa forma existiriam limitações claras se houvesse a tentativa de transpor 0 conceito de competência, como entendido em psicologia ou linguística, por exemplo, para o campo da educação, ou para qualquer outro campo. Essa transposição exige adaptações que para Jonnaert, "estão longe de serem menores" (JONNAERT, 2009).

Contudo, é interessante notar que diversos aspectos daquilo que apresentamos sobre competências podem ser verificados em algumas linhas de desenvolvimento de currículos. É possível que as competências sejam entendidas como virtuais também em educação, a potencialidade do estudante, que se manifesta por meio de seu desempenho em testes e provas, assim como o entendimento dos linguistas. Esses testes podem ser ou não desenvolvidos de modo que o aluno precise analisar uma situação.

Em outros sistemas de ensino é possível que as competências sejam critérios com base nos quais os alunos serão avaliados de acordo com seu desempenho, a comparação com competências estabelecidas pode classificar os estudantes em uma determinada escala, a lista das competências poderia inclusive ser atualizada de acordo com o desempenho desses estudantes, ou da eficiência que tal lista possui em fornecer informações sobre estudantes de forma individual ou coletiva. Esse entendimento das competências se parece em muito com aquele utilizado pelos psicólogos, assemelhando-se também com o que se observa na prática de exames em larga escala, como o ENEM. Essa questão é abordada por Jonnaert et al. (2010), pois, para os autores, a competência depende da existência de uma situação e se revela na ação executada nessa situação, como se poderia então listar as competências que devem ser desenvolvidas sem que esta lista se torne critério avaliativo para classificar os alunos. Para evitar esse risco, seria preciso "pensar em novas vias para a redação dos programas de ensino" (JONNAERT et al., 2010) que obedecem a lógica de competências. 


\subsubsection{A definição de Philippe Perrenoud}

Sociólogo e antropólogo suíço, Philippe Perrenoud é professor da Universidade de Genebra na área de Ciências da Educação e possui diversas obras dedicadas à temática das competências.

O autor define as competências como "uma capacidade de agir eficazmente em um determinado tipo de situação, apoiada em conhecimentos, mas sem limitar-se a eles" (PERRENOUD, 1999). Contudo, esta definição não é rígida. Em Zabala e Arnau (2010) é citada, e atribuída à Perrenoud no ano de 2001, uma nova definição para o conceito de competência.

é a aptidão para enfrentar, de modo eficaz, uma família de situações análogas, mobilizando a consciência de maneira cada vez mais rápida, pertinente e criativa, múltiplos recursos cognitivos: saberes, capacidades, microcompetências, informações, valores, atitudes, esquemas de percepção, de avaliação e de raciocínio (PERRENOUD, 2001 - como citado em ZABALA E ARNAU, 2010)

A "eficácia" é um dos elementos que persistem nas duas definições. A eficácia da escola é um dos temas discutidos por Perrenoud. De acordo com ele, uma crescente demanda por escolarização, e um possível aumento no nível de escolarização tem suscitado dúvidas quanto a capacidade de jovens inserirem-se em sociedade de maneira relevante, tolerante e responsável. Perrenoud (1999) insiste que

em cada sociedade desenvolvida, a opinião pública e a classe política não estão mais dispostas a somente apoiar o crescimento sem fim dos orçamentos da educação[...], querem uma escola mais eficaz, que prepare melhor para a vida. (PERRENOUD, 1999)

A "situação" é também um termo que aparece nas duas definições de Perrenoud. Na primeira, o autor refere-se a um "determinado tipo de situação", ao passo que na segunda definição, parece haver uma ampliação nas fronteiras daquilo com o que o aluno deve ser capaz de lidar ao se referir a "uma família de situações". Ou seja, a competência adquirida não deve permitir ao aluno apenas a mera repetição de um procedimento, dado que a mera repetição, só é possível caso as condições do problema enfrentado sejam as mesmas do problema treinado. Um soldado que treina seus movimentos em equipamentos inanimados ou com um companheiro que não intenta feri-lo, não 
pode esperar as mesmas condições em uma situação real de combate, embora a situação seja análoga.

É preciso que, ao enfrentar uma situação de determinada família, tal enfrentamento seja feito baseado em um conjunto de conhecimentos pertinentes àquela situação. No exemplo anterior, a possível competência do soldado em assar bolos é pouco relevante em situação de combate, dado que a família de situações em que os conhecimentos relacionados a assar bolos se aplicam, são de natureza distinta da situação de combate. Por isso o autor indica em sua primeira definição o enfrentamento de situações deve ser feito apoiado em conhecimentos. Mas os conhecimentos relacionados a uma determinada família de situações não são os únicos elementos que influenciam em seu enfrentamento, "saberes, capacidades, microcompetências, informações, valores, atitudes, esquemas de percepção, de avaliação e de raciocínio" (PERRENOUD, 1999) também devem ser gerenciados e articulados de modo eficiente. Do ponto de vista da definição mais recente atribuída à Perrenoud, uma competência relaciona-se ao gerenciamento de múltiplos recursos, de naturezas diversas, mobilizados para dar a melhor resposta a determinada situação.

A imagem a seguir apresenta um mapa conceitual que pretende organizar a definição de competência tal como apresentada por Perrenoud, evidenciando os conceitos chave e suas relações.

Figura 2.4- Mapa conceitual que apresenta a estrutura básica do conceito de competência de acordo com a definição de Philippe Perrenoud (1999).

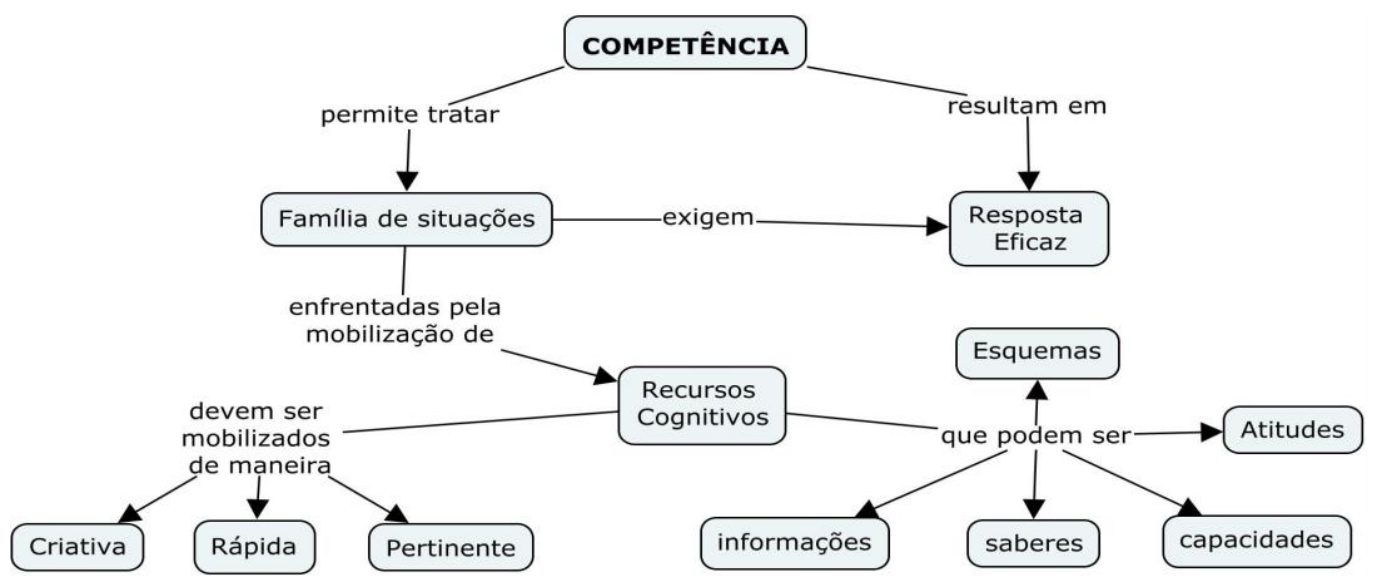

Fonte: Elaborado pelo Autor. 


\subsubsection{A definição de Philippe Jonnaert}

Philippe Jonnaert, de maneira provisória, define as competências da seguinte maneira:

Através de uma competência, um sujeito mobiliza, seleciona e coordena uma série de recursos (de que fazem parte alguns dos seus conhecimentos, mas também uma série de outros recursos que seriam afetivos, sociais e os que estão ligados à situação e aos seus constrangimentos) para tratar eficazmente uma situação. Uma competência supõe, para além do tratamento eficaz, que esse mesmo sujeito pouse um olhar crítico sobre os resultados desse tratamento que deve ser socialmente aceitável. (JONNAERT, 2009, p. 63).

Embora as definições de Jonnaert e Perrenoud guardem diversas semelhanças, é possível observar uma importante amplificação quanto ao entendimento do conceito.

Jonnaert também apresenta o conceito de mobilização de recursos, mas a mobilização é apenas uma das ações atribuídas a uma competência, é preciso também selecionar e coordenar. Cada sujeito possui diversos recursos, relacionados aos mais diversos contextos. Ao enfrentar determinada situação é preciso que o sujeito consiga recorrer aos recursos que Ihe estão disponíveis. O próximo passo é selecionar os recursos relevantes. Nem tudo o que está disponível para tratar alguma situação é adequado ou trará benefício no enfrentamento da situação. De fato, é possível que um recurso utilizado de maneira inadequada afaste o sujeito de uma solução eficaz. Por fim, é preciso coordenar os recursos. A ordem e intensidade com que cada um deles deve ser utilizado também influencia no tratamento da situação. $O$ sujeito mais competente não será, necessariamente, aquele com maior quantidade de saberes, pois a competência não trata da soma e empilhamento de conteúdos, mas aquele que melhor gerencia a articulação entre os recursos disponíveis (JONNAERT, 2009).

Jonnaert também amplia o entendimento dos recursos a serem mobilizados. Enquanto em sua definição mais completa Perrenoud se refere à mobilização de recursos cognitivos, Jonnaert apresenta dois tipos de recursos, aqueles que dizem respeito ao sujeito e sua história, em que os conhecimentos (alguns deles) compõem os recursos juntamente com questões de ordem 
afetiva e social, e aqueles que dizem respeito à situação e às suas limitações ou constrangimentos. Um jornalista pode ser considerado competente ao mobilizar seus próprios recursos, sua habilidade de escrever diferentes tipos de textos, sua vivência no assunto sobre o qual escreve suas pesquisas e conhecimentos prévios a respeito de determinado assunto. Contudo, ao escrever o texto, deve considerar também os recursos e limitações circunstanciais, ou seja, aqueles ligados à situação. Ele pode ter um computador disponível ou apenas papel e caneta, pode ter o espaço de uma página ou de apenas algumas linhas para apresentar seu texto, pode ter um prazo de uma semana ou de poucas horas para fazer o envio. É competente portanto, o sujeito que coordena não só os próprios recursos, mas aqueles apresentados dentro da situação e muitas vezes limitados por ela.

E embora Jonnaert, assim como Perrenoud, apresente a necessidade de que o tratamento da situação seja eficaz, para ele, a competência ultrapassa essa demarcação, sendo necessário também considerar o olhar crítico do sujeito e a aceitação social da ação competente realizada.

Não deve bastar ao sujeito, apresentar um tratamento eficaz à situação enfrentada, é necessário ser capaz de julgar de maneira crítica os resultados obtidos. Neste ponto, a definição de Jonnaert revela uma dimensão ética das competências. Ao sujeito competente, não basta tratar uma situação de modo a obter os resultados desejados, é preciso julgar primeiramente quais resultados se deseja alcançar. Do ponto de vista estritamente operacional, um ladrão de bancos pode ser considerado competente caso consiga concluir um assalto sem ser pego e sem que ninguém seja ferido. Considerando também que o resultado obtido deve ser socialmente aceito, a solução para os problemas relacionados às pessoas que vivem em situação de rua, por exemplo, não pode ser, forçadamente, enviar essas pessoas para periferias distantes ou até para outras cidades. É certamente uma solução eficaz, que exige a mobilização de diversos recursos, mas é obviamente inaceitável do ponto de vista social e revelaria a ausência de qualquer pensamento crítico por parte do sujeito por ela responsável.

É importante ressaltar que a situação é elemento de grande importância para Jonnaert assim como para Perrenoud. Jonnaert afirma que 
uma competência é, portanto, sempre contextualizada numa situação precisa e é sempre dependente da representação que a pessoa faz para si dessa situação" (JONNAERT, 2009, p. 58).

Fica ainda mais claro o papel da situação na definição de Jonnaert, uma vez que parte dos recursos e das limitações é determinada pela situação. Para ele "a competência torna-se indissociável dos contextos em que se manifesta e das situações que permite tratar" (JONNAERT, 2009, p. 54).

A imagem a seguir apresenta um mapa conceitual que organiza os principais conceitos e as relações encontradas na definição de competência de Philippe Jonnaert.

Figura 2.5- Mapa conceitual que apresenta a estrutura básica do conceito de competência de acordo com a definição de Philippe Jonnaert (2009).

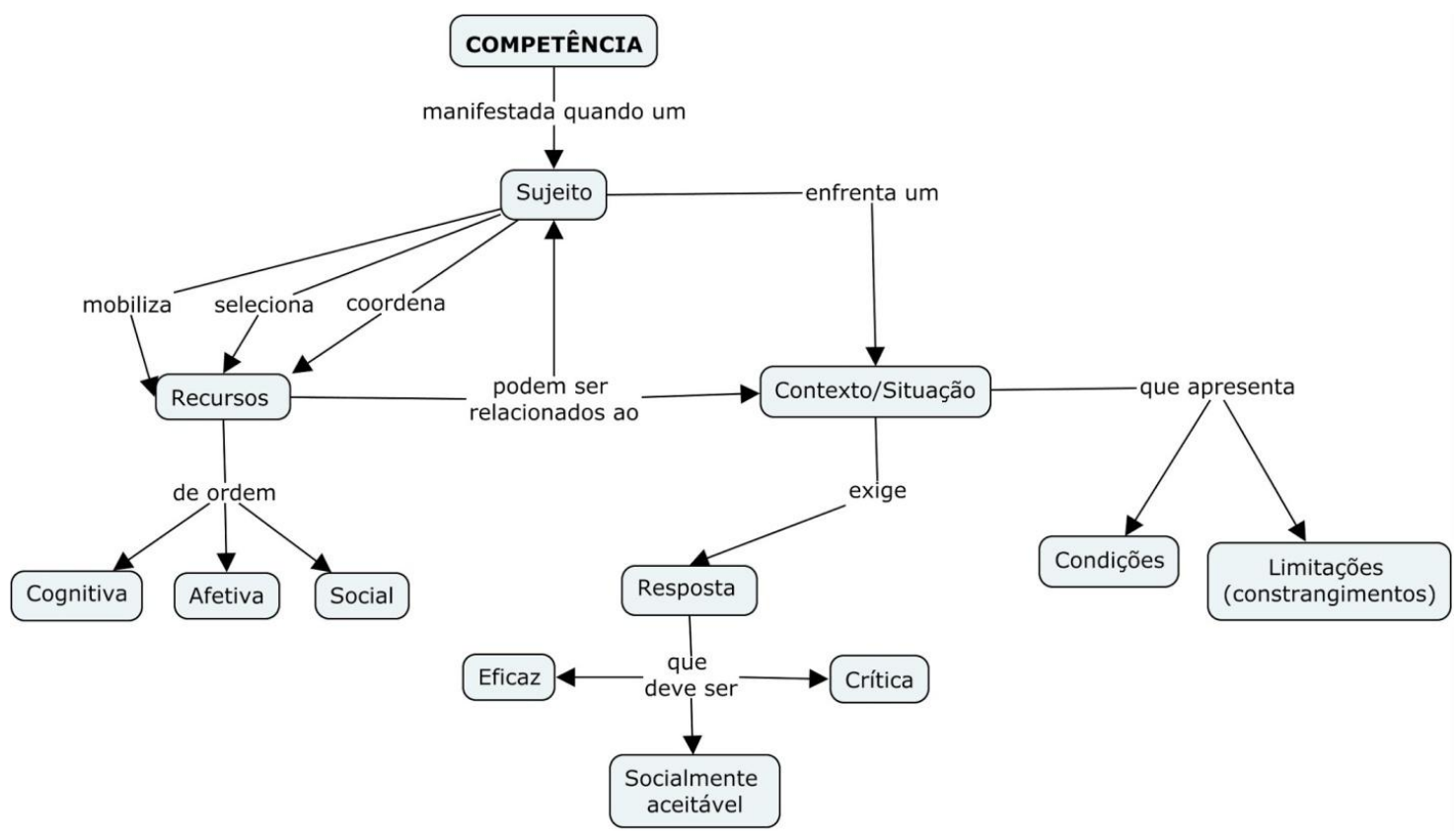

Fonte: Elaborado pelo Autor.

O mapa anterior apresenta um número ligeiramente maior de conceitos e relações quando comparado ao mapa apresentado para a definição de Perrenoud. 


\subsubsection{A definição de Antoni Zabala e Laia Arnau}

Espanhol, Antoni Zabala tem formação em filosofia e ciências da educação e atualmente é presidente do Campus Virtual de Educação da Universidade de Barcelona (educpedcurrículo).

Perrenoud e Jonnaert, embora tenham nacionalidades diferentes, são ambos falantes da língua francesa ${ }^{4}$. Zabala e Arnau são autores de fala espanhola, esta importante diferença cultural, pode marcar algumas distinções a respeito da visão deste autor acerca das competências em comparação com os anteriores.

Zabala e Arnau apresenta a seguinte definição para uma competência:

A competência identificará aquilo que qualquer pessoa necessita para responder aos problemas aos quais se deparará ao longo da vida. Portanto, competência consistirá na intervenção eficaz nos diferentes âmbitos da vida mediante ações nas quais se mobilizam, ao mesmo tempo e de maneira inter-relacionada componentes atitudinais, procedimentais e conceituais. (ZABALA, A.; ARNAU, L., 2010, p. 37).

Em princípio, identificaremos os elementos citados nas definições anteriores, para então apresentar os novos elementos.

A eficácia das ações é novamente citada. A ideia de que as ações ou respostas às situações devem ser eficazes, para que então se evidencie uma competência é comum em todas as definições aqui apresentadas. Dessa forma, de acordo com as definições discutidas, parece certo afirmar que, uma resposta eficaz pode revelar um sujeito competente, ao passo que uma resposta ineficaz evidencia e incompetência do sujeito em lidar com determinada situação. Contudo, Zabala e Arnau explicam que "as pessoas não são competentes, mas sim que em cada situação demonstram um maior ou menor grau de competência para resolvê-la de forma eficaz" (ZABALA E ARNAU, 2010, p. 41). Ou seja, o resultado de uma ação, em resposta a um problema enfrentado, não determina a competência ou incompetência definitiva de um sujeito, mas revela uma maior ou menor capacidade para resolver

\footnotetext{
${ }^{4} \mathrm{Na}$ parte ocidental da Suíça, o francês é o idioma predominante. O Canadá tem o inglês e o francês como idiomas oficiais. No Quebec, é o francês o idioma predominante.
} 
determinada situação, que pode ser parecida com outras de mesma natureza, mas que carrega suas próprias especificidades.

A ideia de mobilização também está presente na definição de Zabala e Arnau, que apresenta as categorias ou os componentes "atitudinais, procedimentais e conceituais" (ZABALA, A.; ARNAU, L., 2010) que devem ser mobilizados. É importante notar que, para os autores, a mobilização deve se dar "ao mesmo tempo e de maneira inter-relacionada" e não de forma isolada para cada um desses componentes. As componentes citadas são percebidas a partir da análise das definições em diversos autores e se relacionam com três grandes domínios; ser (componentes atitudinais), saber fazer (componentes procedimentais) e saber (componentes conceituais) (ZABALA E ARNAU, 2010).

$\mathrm{Na}$ definição de Zabala e Arnau, a competência tem o papel de identificação de necessidades, ou seja, a competência se manifesta na medida em que o sujeito consegue traçar um caminho de resposta àquilo que enfrenta. E embora, Zabala e Arnau retomem depois o termo "situação", em sua definição o sujeito enfrenta um "problema", o que confere um pouco mais de especificidade àquilo que é enfrentado.

Embora nas outras definições não apareçam de forma evidente as delimitações em que as competências se manifestam, é interessante Zabala e Arnau indicarem que o sujeito de deparará com diferentes problemas ao longo da vida em diferentes âmbitos. Essa ênfase dá alguma amplitude para o alcance das competências, o que é de grande importância para um ensino que se propõe a "educar para a vida".

Por fim, a ideia de ação, encontrada em Zabala e Arnau, também especifica o tipo de enfrentamento aos problemas por parte do sujeito. Não se trata de um enfrentamento ou tratamento em sentido amplo e geral, mas de uma ação, de maneira muito mais clara e diretiva nos domínios apresentados por Zabala e Arnau; saber, ser e saber fazer.

Novamente é apresentado a seguir um mapa conceitual com o objetivo de compilar as principais informações encontradas na definição de Zabala e Arnau de modo a facilitar a comparação com as definições dos outros autores. 
Figura 2.6- Mapa conceitual que apresenta a estrutura básica do conceito de competência de acordo com a definição de Zabala e Arnau (2010).

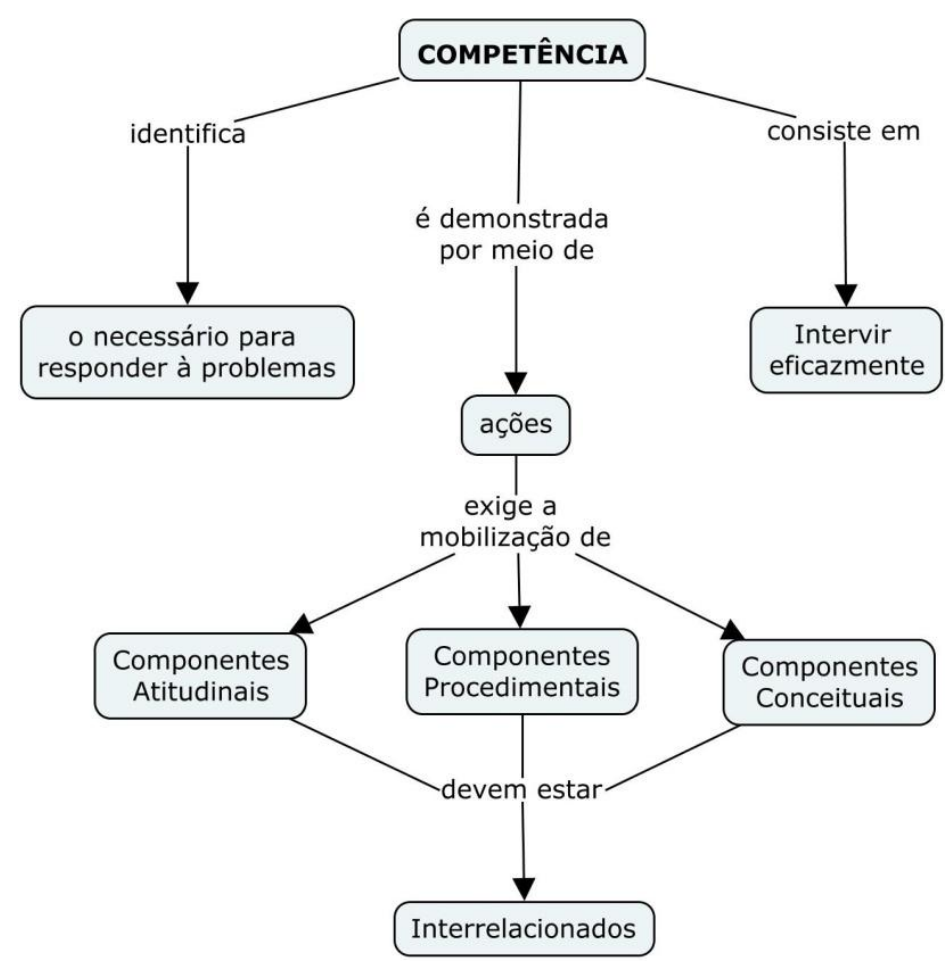

Fonte: Elaborado pelo Autor.

\subsubsection{Comparando definições}

Para retomar as definições apresentadas serão feitos alguns comentários com base nos mapas conceituais apresentados, que permitem uma visão mais sucinta das ideias dos autores.

Embora existam diferenças consideráveis entre as definições, parece haver um fio condutor que estrutura a ideia de competência. Em princípio não parece haver uma divisão entre o ensino de competências, e um processo de avaliação para então dizer se um determinado sujeito é ou não competente. Os recursos, sobretudo os cognitivos podem ser ensinados, e fazem então parte do repertório do sujeito, mas as competências parecem se manifestar (ou não), se desenvolver (ou não) e serem avaliadas de maneira quase que concomitante em torno e através de uma situação.

Uma situação/contexto com um problema sempre deve ser apresentada. Ao definir e delimitar o problema e a situação o sujeito em 
questão deverá acessar uma série de recursos (ou componentes como em Zabala e Arnau). Tais recursos, sobretudo quando dizem respeito ao sujeito, podem ser de ordem cognitiva, atitudinal, social, procedimental etc. Cabe ao sujeito selecionar quais são mais adequados à situação em questão de modo a produzir uma resposta/intervenção eficaz. E é nesse processo que a competência é "ensinada”, se desenvolve e é avaliada.

No mapa que representa a definição de Perrenoud, os recursos dizem respeito essencialmente ao sujeito. O autor também especifica que esses recursos devem ser mobilizados de maneira criativa, rápida e pertinente, enfatizando o processo de mobilização.

Jonnaert, além dos recursos de diversas ordens relacionados ao sujeito, também coloca como elementos dos recursos, aqueles relacionados à situação, às suas condições e limitações (constrangimentos). E embora também apresente a necessidade de uma resposta eficaz, da ênfase na necessidade de que essa resposta também seja crítica e socialmente aceitável, ou seja, Jonnaert marca de maneira muito clara que os fins não justificarão os meios.

Em Zabala e Arnau, um mapa mais simples, mostra a necessidade de ação. Não basta ao sujeito dar uma resposta ao problema, mas é preciso intervir no problema de maneira eficaz. É também uma ênfase no processo, mas de maneira diferente de Perrenoud.

Alguns elementos se destacam por sua presença constante nas definições apresentadas. A situação, a mobilização de recursos e os saberes são elementos estruturantes que parecem ser básicos para que se possa discutir competências. A eficácia das respostas apresentadas às situações também está presente nas definições de maneira muito destacada, contudo, por sua maior complexidade, discutiremos este termo no capítulo 7.

Em seguida, será dada maior atenção à comparação de termos importantes que de maneira explícita ou implícita estão presentes nas definições apresentadas. É importante lembrar que os termos selecionados são um recorte daquilo que é apresentado nas definições. Não se pretende portanto que seja uma seleção definitiva ou que encerre todos os sentidos das competências apresentados nas definições. 


\subsection{Sistematização de sentidos}

\subsubsection{Situação ou contexto}

Nas duas definições de Perrenoud e na definição de Jonnaert, apresentadas anteriormente, a situação é enfrentada pelo sujeito. Embora Zabala e Arnau não utilizem o termo "situação", falam de problemas que deverão ser enfrentados pelo sujeito, o que pode ter um sentido similar. A competência, portanto se manifesta na mobilização de recursos para a resolução daquilo que se enfrenta na situação (ou "nos problemas [com que] se deparará ao longo da vida" em Zabala e Arnau). Dessa forma, parece que não há manifestação da competência, caso uma situação que exija uma resposta, não seja de fato apresentada ao sujeito. Jonnaert (2009) afirma que sua hipótese é a de que "uma competência não pode ser definida a não ser em situação".

Ao exemplificar a mobilização de recursos, Perrenoud (2009) problematiza o ensino de línguas estrangeiras na escola, que mesmo se dando ao longo de muitos anos é de fato testado quando na necessidade de se comunicar com um estrangeiro em uma língua diferente da materna. Portanto é a situação que apresenta a oportunidade de manifestação da competência.

Perrenoud assume que nossas vidas são relativamente equilibradas para desenvolver seu entendimento das situações que serão enfrentadas, afirmando que "a vida humana encontra um equilíbrio [...], entre as respostas rotineiras para situações semelhantes e as respostas a serem construídas para enfrentar obstáculos novos." (PERRENOUD, 1999, p. 29). Portanto, excetuando-se condições extremas de vida, Perrenoud apresenta dois tipos de situação; aquelas que guardam semelhança com outras anteriormente enfrentadas e aquelas que são absolutamente novas.

É possível exemplificar o desenvolvimento de competências em situação com a competência de dirigir um veículo, exemplo trabalhado por Perrenoud (1999). Uma pessoa que dirige todos os dias para o trabalho enfrenta, ao dirigir, uma situação rotineira, que exige ações e a utilização de esquemas específicos. Embora a situação não seja absolutamente a mesma, uma vez que os outros carros não devem estar exatamente na mesma 
disposição todos os dias, é sempre muito semelhante, que o motorista deve sempre estar atento aos seus espelhos retrovisores e aos carros à sua volta.

Caso esse motorista faça uma viagem para determinado local pela primeira vez, alguns procedimentos, como observar os outros carros pelos retrovisores, devem ser reproduzidos, outros, como consultar um mapa, decidir sobre a necessidade de parar em um posto de serviços ou avaliar as condições de segurança de uma estrada podem não ser tão rotineiros ou até precisarão ser construídos a partir de recursos disponíveis para enfrentar uma situação absolutamente nova.

Mesmo reconhecendo que na vida existem situações extremas que não necessariamente se repetirão, exigindo um grupo de ações muito específico, Perrenoud afirma que "a maioria de nossas competências é construída [...] por meio de situações semelhantes o bastante para que cada uma possa contribuir na construção progressiva de uma competência." (PERRENOUD, 1999, p.29). Ou seja, o motorista do exemplo proposto, teve sua própria competência de dirigir desenvolvida ao enfrentar a situação de uma viagem para um local novo, precisando construir esquemas específicos que podem, ou não, ser mobilizados novamente nas situações corriqueiras e mais usuais.

Para Perrenoud, embora as competências sejam desenvolvidas para enfrentar situações na vida, no âmbito profissional, as situações de razoável semelhança reproduzem-se de maneira muito profusa, e em geral, com uma carga de exigência de eficácia maior em comparação com as situações da vida privada, o que em certa medida privilegia o desenvolvimento de competências profissionais (PERRENOUD, 1999, p.29).

No texto do autor também é trabalhado o conceito de Analogia em contraposição à Competência para a resolução de determinada situação. Algumas situações permitem uma resolução simplificada a partir da utilização de esquemas previamente estabelecidos em situações de grande similaridade. Nestes casos a solução para a situação enfrentada, mesmo que inédita, dá-se de maneira quase que imediata por Analogia com situações anteriores, tratase, portanto de uma transferência de esquemas de resolução (PERRENOUD, 1999). 
O enfrentamento de situações de maior complexidade exigem um grau de criatividade e maior articulação de recursos, quando a competência se manifesta elaborando uma solução inédita. A competência pode, segundo Perrenoud, fazer uso de analogias para a construção da solução esperada, mas essa resposta não é imediata, pois as analogias não são evidentes. Algumas vezes é também necessário que a situação seja desmembrada e que em partes diferentes façam-se analogias com situações diferentes, para que aos poucos uma solução se desenvolva.

Jonnaert (2009) ao tratar das competências, elabora o que seria a "arquitetura" do conceito. Como é reconhecido pelo autor, a divisão apresentada é claramente "artificial", mas é capaz de organizar o seu argumento sobre a constituição das competências de maneira coerente (JONNAERT, 2009).

Para este autor, a situação é o primeiro e mais importante elemento da arquitetura da competência. É a situação que permite a manifestação e o próprio desenvolvimento da competência. Ela é "o ponto de partida e o principal critério que servirá para verificar se a competência foi eficaz ou não na sua aplicação" (JONNAERT, 2009, p. 92). A importância da situação para Jonnaert é tão grande que ele afirma que os programas de ensino, sobretudo aqueles que se dizem organizar por competências, deveriam ser propostos com base em situações e classes de situações e não com base em conteúdos. Dessa forma, as competências dependem das situações em uma dimensão contextual, não cognitiva, que as constitui.

Para Jonnaert (2009), uma situação carrega em si, de forma simultânea, um caráter global e específico, e é essa aparente contradição que determina as características da competência. $O$ autor explica que o caráter específico da situação está relacionado às suas peculiaridades. Ou seja, por mais que uma situação possa ter similaridades com outras, existem características exclusivas daquela situação única ou de um conjunto de situações similares. O caráter global da situação é caracterizado pelos recursos que podem ser mobilizados para que se enfrente a situação e que não estão restritos à recursos cognitivos, mas envolvem capacidades e recursos relacionados ao sujeito e à situação em si. 
Em concordância com esses autores, Zabala e Arnau (2010) atribui às competências "um caráter essencialmente contextual", o que levanta o debate sobre se as competências podem ou não ser ensinadas. $O$ autor atribui às raízes desse debate uma visão transmissiva de ensino. Como as competências possuem fortes características procedimentais e atitudinais, e que se desenvolvem em sinergia com a situação na qual são requeridas, sendo impossível prever em detalhe as situações enfrentadas pelos estudantes, seria, portanto incoerente a proposta de se ensinar competências. Contra este posicionamento Zabala e Arnau argumentam que mesmo em um ensino transmissivo, aquilo que se ensina e que muitas vezes prescinde de um contexto, não será apenas transferido para uma situação, mas será reformulado para atender à situação. Dessa forma, é possível, mesmo que não seja o ideal, que conhecimentos adquiridos de maneira desconectada possam ser acessados para resolver uma situação específica.

Para Zabala e Arnau, a proposta de um ensino por competências deve propor o enfrentamento de situações reais pelos alunos, para que as respostas à situações futuras e também reais possa ser mais eficiente. Zabala e Arnau reconhecem que as competências do futuro não podem ser ensinadas, pois seu desenvolvimento dependerá das situações que o estudante enfrentará no futuro, "mas sim seus esquemas de atuação e sua seleção e prática em distintos contextos generalizados" (ZABALA E ARNAU, 2010).

Semelhante à arquitetura das competências apresentada por Jonnaert (2009), Zabala e Arnau (2010) apresentam os critérios relacionados ao ensino de competências. Para os autores, as competências devem apresentar: relevância, situações complexas, caráter procedimental, integração de componentes de natureza distinta. Todos esses critérios devem se integrar de modo a revelar as competências em situações reais.

Dessa forma, para estes autores, a situação enfrentada possui papel fundamental no que diz respeito a um currículo por competências. A situação, que deve ser o máximo possível aproximada de um quadro real, possui uma dupla função. Por um lado ela revela a competência, pois é em situação que o sujeito terá a oportunidade de selecionar seus conhecimentos e recursos com 0 objetivo de resolver a situação de forma efetiva. Portanto é na situação que o 
sujeito pode ser efetivamente avaliado. É na situação que o sujeito decidirá se os recursos disponíveis (sobretudo os recursos cognitivos e emocionais) são suficientes, ou se existe algum ponto que necessite de melhoria, ou outros a serem desenvolvidos. É na situação que o sujeito revelará sua capacidade, ou não, de mesmo com recursos disponíveis, mobilizar de maneira integrada aqueles que são adequados à situação.

\subsubsection{Transferência e Mobilização de recursos}

O conceito de mobilização envolve de maneira básica a seleção e utilização de recursos disponíveis para a resolução de problemas em uma determinada situação. É importante notar, contudo que o termo "mobilização" está mais fortemente relacionado com Perrenoud, como aquilo que se utiliza ou se pode utilizar para resolver determinada situação. Embora utilizemos o termo de maneira mais próxima ao entendimento de Perrenoud, faremos a seguir um estudo sobre como esta ideia se apresenta nos outros autores, independentemente da utilização do termo.

Dada a situação a ser enfrentada pelo sujeito, seja em situação escolar ou fora dela, alguma resposta ou solução precisará ser apresentada aos desafios enfrentados. Como foi dito anteriormente, os quatro autores concordam que a resposta deve ser eficaz, embora o entendimento de eficácia possa variar de autor para autor. É também comum a estes autores o conceito de recursos, isto é, algo de que o aluno possa fazer uso para construir sua resposta ou solução para a situação enfrentada.

Existe alguma diferença entre entendimento de "mobilização de recursos" de Perrenoud e o entendimento Jonnaert. Além disso Zabala e Arnau não utilizam a palavra "recurso" em sua definição, mas mobilização de "componentes, atitudinais, procedimentais e conceituais" (ZABALA E ARNAU, 2010).

Perrenoud, quando trata do processo de mobilização de recursos, dá ênfase aos recursos cognitivos, ou conhecimentos relacionados a determinadas áreas ou disciplinas, mas que podem, eventualmente e dependendo da situação, serem mobilizados para a solução de situações de áreas distintas. Para Perrenoud os conhecimentos são necessários, mas não 
suficientes para que uma competência se manifeste. É preciso, além de obter os conhecimentos necessários para o enfrentamento de uma determinada situação, ou de situações de certa área de conhecimento, ser capaz de mobilizar os conhecimentos pertinentes a cada situação. Segundo Perrenoud (1999) "construir uma competência significa aprender a identificar e a encontrar os conhecimentos pertinentes" (PERRENOUD, 1999, p.22) em que o processo de encontrar os "conhecimentos pertinentes" é sinônimo de "mobilização".

Com relação às competências, Perrenoud ao explicar o processo de mobilização também vai afirmar que "a construção de competências [...] é inseparável da formação de esquemas de mobilização ${ }^{5}$ dos conhecimentos" (PERRENOUD, 1999, p.10).

Segundo este autor, o desenvolvimento de uma competência estável, não é revelada somente pela capacidade de selecionar os conteúdos corretos, essa capacidade está ao alcance de qualquer pessoa, mas acontece por um "tatear reflexivo". Para que exista uma "competência estabilizada" é preciso que sejam acessados os esquemas "constituídos" de mobilização. Analogamente, um praticante de artes marciais ao treinar diversos golpes de maneira isolada, consegue também treinar esquemas de defesa $e$ ataque quase simultaneamente que podem se repetir de maneira automatizada, sem que 0 lutador precise refletir qual seria 0 melhor golpe a se encaixar naquele momento. Mas é importante notar que o esquema de defesa e contra-ataque não é um esquema aplicado de maneira irracional, pois em situação de combate, o lutador precisará traçar estratégias de acordo com as características de seu oponente.

Dessa forma, o lutador competente traça uma estratégia com base na análise da situação, acessando os recursos disponíveis, mas mobilizando esquemas automatizados em respostas a pequenas variações enfrentadas na situação em questão.

Jonnaert também propõe uma ação que ultrapasse a simples mobilização. Para ele é necessário que "os sujeitos organizem esses recursos diversos em redes operatórias "." (JONNAERT, 2009, p. 55). Existe contudo uma

\footnotetext{
${ }^{5}$ Destaque deste autor.

${ }^{6}$ Destaque deste autor.
} 
distinção entre os esquemas de Perrenoud e as redes operatórias de Jonnaert. Enquanto aqueles dizem respeito a uma ação quase que automatizada em resposta a desafios particulares da situação, estas demandam uma capacidade de reflexão e articulação dos recursos, uma visão mais geral da situação de modo a produzir um resultado eficaz. Para Jonnaert, se os blocos de construção, são os recursos disponíveis para o enfrentamento de uma situação, as redes operatórias ultrapassam uma simples mobilização, pois são a organização capaz de produzir uma casa, em lugar de um simples amontoado de tijolos.

Em Zabala e Arnau (2010), não foi encontrada menção do termo "mobilização de recursos", a não ser na definição que o autor dá para as competências. Contudo, na sequência apresentada pelo autor para uma "atuação competente" o primeiro de quatro passos é a identificação do problema a ser enfrentado, o que pode ser entendido como uma análise delineadora da situação. O segundo e o terceiro passos dizem respeito a como o problema será enfrentado, exigindo do sujeito "revisar os esquemas de atuação de que [dispõe, que aprendeu] e que são os mais adequados para enfrentar a situação em questão" (ZABALA E ARNAU, 2010, p. 38). Zabala e Arnau não parecem discutir ou diferenciar a fase de simples mobilização da fase de estabelecimento de um esquema de mobilização ou rede operatória como em Perrenoud e Jonnaert, mas o tratamento que dão para o termo "esquemas de atuação" se parece muito com uma fase mais madura de mobilização. Para eles é preciso

Selecionar o esquema de atuação mais apropriado [...]. A partir desse momento [o sujeito pode] passar a aplicar o esquema de atuação, mas sempre a partir de uma posição estratégica, ou seja, empregando-o de forma flexível e adequando-o às características específicas da situação real. (ZABALA E ARNAU, 2010, p. 39).

Com relação à função dos recursos e das próprias competências Perrenoud atribui um papel duplo para este conceito. Embora enfatize o caráter cognitivo dos recursos mobilizáveis. Perrenoud dá às próprias competências a possibilidade de serem classificadas como recursos. Competências mais específicas, menos abrangentes, podem ser recursos mobilizáveis para competências mais complexas. 
Por ora, insistamos nessa dupla face ${ }^{7}$ de toda competência, que pode, conforme o momento, mobilizar recursos ou funcionar como recurso em proveito de uma competência mais ampla. (PERRENOUD, 1999, p. 28).

Este processo que é comparado pelo autor com as tradicionais bonecas russas que são organizadas umas dentro das outras.

Assim como as competências, os recursos possuem para os autores sentidos diversos. Parece haver concordância de que os recursos são os elementos disponíveis para a resolução dos problemas em situação enfrentados pelo sujeito. Podem ser recursos internos, (conhecimentos prévios, capacidade de obter determinado conhecimento, características de personalidade, atitudes) ou externos ao sujeito (material disponível, recursos financeiros, proximidade de fornecedores). Parece também haver concordância em que, para ser competente, não basta ao sujeito ter à disposição estes recursos, nem mesmo fazer uma mobilização simplória ou desordenada de

recursos disponíveis. É necessário selecionar os recursos adequados à situação mobilizando-os de maneira integrada e bem articulada, identificado como esquema de mobilização em Perrenoud, rede operatórios em Jonnaert ou esquema de atuação em Zabala e Arnau, que embora apresentem algumas diferenças entre si, de forma geral, indicam um processo de mobilização avançado.

\subsubsection{Saberes}

No item anterior foi apresentada a noção de mobilização de recursos para o enfrentamento de uma situação ou problema. A natureza desses recursos, assim como as próprias competências, é também múltipla e será discutida nesta seção.

Os recursos necessários para oferecer resposta a uma determinada situação podem ser internos ou externos ao sujeito, como discutido anteriormente. Jonnaert (2009) exemplifica que os recursos podem ser cognitivos, (os conhecimentos disciplinares, a bagagem de conhecimentos empíricos, etc.), portanto internos ao sujeito. Mas podem ser também recursos

\footnotetext{
${ }^{7}$ Ibid.
} 
sociais, no caso de um repórter que precisa realizar entrevistas e portanto, precisa da colaboração do público, ou podem ser recursos materiais, no caso de um cirurgião que precisa de equipamentos adequados para realizar alguma intervenção. Estes são exemplos de recursos externos ao sujeito.

A falta de qualquer um dos recursos pode significar a ineficácia da resposta dada à situação. É impossível que um cirurgião, por mais erudito e especializado que seja em sua área, obtenha resultados eficazes se os equipamentos a ele oferecidos não forem minimamente adequados para aplicar seus conhecimentos, ou seja, se the faltarem os recursos materiais mínimos. A competência, portanto se revelará na capacidade do sujeito em mobilizar e articular os recursos disponíveis, pressupondo-se que estes recursos, independentemente de sua natureza, atendam ao mínimo necessário para a realização da tarefa empreendida.

É interessante notar que não há lista definitiva de recursos, isto é, o mesmo sujeito pode mobilizar recursos diferentes em situações diferentes. $O$ cirurgião exemplificado pode solucionar uma apendicite, mas não um transplante de coração, não necessariamente por uma limitação cognitiva, mas possivelmente por uma limitação de equipamentos disponíveis para realizar a cirurgia mais complexa. Por outro lado, um cirurgião com mais ou melhores recursos cognitivos, neste caso recursos internos, pode solucionar problemas complexos mesmo com a falta de alguns. Neste caso é também importante que o cirurgião tenha controle sobre suas emoções para enfrentar uma situação de risco, mesmo com pouco material ou com materiais inadequados. Esse controle é de natureza diferente dos conhecimentos disciplinares, embora também interno ao cirurgião.

A proposta é dispensar maior atenção àquilo que chamamos de recursos internos, e que, de acordo com os autores apresentados, passaremos agora a chamar de saberes. É possível se referir a diversos tipos de saberes de um sujeito. Alguns saberes são adquiridos de maneira formal, por meio de cursos ou da escola, diversos outros saberes são adquiridos de maneira informal, a partir da família, da igreja, da comunidade local.

No capítulo 4 será discutido em maior profundidade que no entendimento geral do que deve ser um ensino organizado por competências, 
parece haver a ideia de que este se contrapõe ao ensino tradicional, de modo que o ensino por competência estaria mais relacionado com saberes práticos ou à capacidade de raciocínio enquanto que o ensino tradicional estaria mais relacionado à saberes cognitivos representados em grande parte por saberes disciplinares. Esse entendimento geral pode induzir à ideia de que um ensino por competências é necessariamente oposto aos saberes disciplinares.

De fato, Perrenoud (1999) argumenta que o termo competência pode ser intercambiável com savoir-faire, termo de origem francesa cuja tradução literal pode ser algo como saber-fazer. Perrenoud apresenta três entendimentos para este saber-fazer, todos de natureza procedimental, que se relacionam a uma ação prática. $O$ entendimento adotado pelo autor e sobre 0 qual faz uma análise mais profunda é que o saber-fazer é "um esquema com uma certa complexidade, existindo no estado prático, que procede em geral de um treinamento intensivo, à maneira do patinador, do virtuoso, do artesão, cujos gestos tornaram-se 'uma segunda natureza' e fundiram-se no habitus." (PERRENOUD, 1999, p. 27). Para Perrenoud portanto, saber-fazer pode ser entendido como uma ação procedimental relativamente automatizada, que é uma competência mobilizável em diferentes situações e que não se confunde com um saber-cognitivo, pois "a mobilização de recursos cognitivos não é a expressão de um saber-fazer específico" (PERRENOUD, 1999).

Perrenoud argumenta em favor de uma redução disciplinar para que se possa pensar em um ensino por competências, mas é importante destacar que não defende a extinção de disciplinas. Para ele "a questão é saber qual concepção das disciplinas escolares [se deve] adotar". Para o autor, existem competências que são essencialmente relacionadas a uma disciplina específica, outras estão no campo de intersecção entre duas, três ou mais disciplinas, outras competências são completamente alheias a qualquer disciplinas e, portanto exigem outros saberes (PERRENOUD, 1999).

Perrenoud argumenta em oposição a uma disciplinarização exclusiva daqueles que "pensam que a escola deve limitar-se a transmitir conhecimentos e desenvolver algumas capacidades intelectuais muito gerais (saber analisar, argumentar, etc.)". O autor chama atenção para a necessidade de que esses

\footnotetext{
${ }^{8}$ Destaque deste autor.
} 
saberes, e outros, produzam atitudes e procedimentos de fato, pois para ele "um 'simples erudito', incapaz de mobilizar com discernimento seus conhecimentos diante de uma situação complexa, que exija uma ação rápida, não será mais útil que um ignorante" (PERRENOUD, 1999). É portanto uma tensão entre o simples saber-cognitivo e um saber-fazer competente.

De acordo com Jonnaert (2009) o próprio Perrenoud diferencia o saberfazer, mais restrito, de um saber-agir mais completo, e que associa as competências ao contexto. Ainda para Jonnaert, algumas competências não são "apenas cognitivas" (JONNAERT, 2009). Não sendo apenas cognitivas, as competências envolvem diversas dimensões de saberes. Contudo, o autor afirma que "uma abordagem das aprendizagens escolares pelas competências não pode ser desprovida de <<conteúdos>>" (JONNAERT, 2009, p. 54). Jonnaert cita Anderson (1986) para falar dos; saber-que (declarativo), sabercomo (processual), saber quando (condicional). Para o autor esses saberes não são apenas cognitivos, mas também conativos $^{9}$. Ou seja, Jonnaert da atenção não só aos conteúdos disciplinares ou aos saberes conceitual (cognitivos ou declarativos), mas também às emoções e sentimentos, e a como lidar com eles, que também constitui um conjunto de saberes. Além dos saberes processuais que fornecerão resultados práticos em relação aos saberes declarativos. Jonnaert, portanto, também não defende a extinção de disciplinas, mas defende que o desenvolvimento de competências deve considerar dimensões que ultrapassam a organização curricular e por isso 0 ensino não pode estar restrito às disciplinas.

Não se passa tudo exclusivamente na cabeça dele. A interação com outras pessoas, num ambiente social, e a interação com o ambiente físico são importantes. Os psicólogos utilizam agora o conceito de 'inteligência distribuída' (distribuited intelligence) para evocar esta redistribuição da atividade intelectual por recursos que não são exclusivamente cognitivos. (JONNAERT, 2009, p. 68).

Zabala, em sua análise das definições de competências presentes em diversos autores, identifica "três grandes domínios relacionados aos campos do

${ }^{9}$ Conação: "Comportamentos e condutas humanas da esfera da afetividade, da emoção, da vontade e da motivação. O domínio conativo diz respeito aos interesses, às atitudes, aos valores. O termo conativo designa caráter, o temperamento, a personalidade por exemplo, a ansiedade, a imagem de si, etc" (Danvers, 1992 como citado em Jonnaert, 2009, p.67) 
saber, do ser, e do saber fazer" (ZABALA E ARNAU, 2010). Os domínios apresentados por Zabala e Arnau são muito parecidos com aqueles trabalhados por Jonnaert. Zabala e Arnau no entanto parecem trabalhar com mais ênfase o ser (que consideraremos como um saber-ser, ou um saber que influencia na ação competente) de natureza atitudinal, mas também discute de maneira detalhada o saber conceitual e o saber-fazer procedimental.

No campo atitudinal, do saber-ser ou o que Zabala e Arnau também chamam de conteúdos atitudinais, são nomeados valores e atitudes, aquilo que deve ser desenvolvido no cidadão que se deseja formar "de acordo com as ideias das quais dispomos sobre qual deve ser o tipo de pessoa ideal e a sociedade que desejamos" (ZABALA E ARNAU, 2010, p. 77). Como conteúdo atitudinal, Zabala e Arnau exemplificam: identidade, solidariedade, respeito aos demais, tolerância, autocontrole, responsabilidade, etc. São apresentados também exemplos de como desenvolver esses conteúdos dentro de um currículo organizado a partir de competências.

Para os conteúdos procedimentais o autor exemplifica: busca, análise, organização, atuação autônoma, trabalho em equipe, comunicação de ideias e informação, etc. Os conteúdos conceituais são aqueles relacionados às mais diversas disciplinas, considerando nesses conteúdos aqueles relacionados às dimensões: social, interpessoal e pessoal.

Portanto, à semelhança dos outros autores, Zabala e Arnau não defendem a eliminação de disciplinas, mas que os conteúdos que farão parte da formação dos estudantes não sejam atrelados apenas a elas. Os saberes conceituais ou cognitivos devem estar integrados com outros saberes que podem ser procedimentais, sociais ou outros de modo a constituir as competências.

Em sua análise das escolas "ativas" Zabala e Arnau deixam muito clara a tensão entre os saberes conceituais e os saberes procedimentais ou o saberfazer. Os autores apresentam um pano de fundo de uma educação tradicional que, com uma visão propedêutica, enfatizava os saberes conceituais. Uma reação a esse modelo de educação teria trazido propostas pedagógicas com grande ênfase em saberes procedimentais, resultando muitas vezes em 
menosprezo dos saberes conceituais fundando-se em um processo de "ação pela ação" a que o autor chama de falso ativismo (ZABALA E ARNAU, 2010).

Quanto a essa tensão Zabala e Arnau se posicionam de maneira muito clara, manifestando a importância essencial dos saberes conceituais para o desenvolvimento de competências verdadeiramente significativas.

O conteúdo procedimental é aprendido quando os alunos thes atribuem sentido e significado, e isso é possível somente quando as atividades são conduzidas sobre conteúdos reais, o que significa, inevitavelmente, sua utilização sobre os objetos de conhecimento. Sem conteúdos conceituais sobre os quais aplicar procedimentos é impossível que eles sejam aprendidos de modo significativo entendendo por isso a capacidade de serem utilizados em qualquer situação. (ZABALA e ARNAU, 2010, p. 48).

Quanto a essa tensão, Zabala e Arnau se posicionam de maneira muito clara, manifestando a importância essencial dos saberes conceituais para o desenvolvimento de competências verdadeiramente significativas. Para ele, não que as disciplinas sejam um empecilho, mas são insuficientes para 0 desenvolvimento de competências (ZABALA e ARNAU, 2010).

Parece, portanto, haver consonância entre os quatro autores no que diz respeito à importância das disciplinas e dos saberes disciplinares ou conceituais, desde que outras dimensões de conhecimento, ou seja, outros saberes, estejam também integrados ao processo de aprendizagem.

Tanto Zabala e Arnau quanto Jonnaert abordam a questão dos saberes disciplinares em contraposição aos saberes procedimentais, comparando tradições latinas e anglo-saxãs de ensino. Para Zabala e Arnau, existe sobre os saberes conceituais uma ênfase exagerada em relação aos saberes procedimentais.

O valor do saber por si mesmo determinou, e ainda determina, as características dos sistemas educacionais e a preeminência da teoria sobre a prática, especialmente nos países de tradição católica que, herdeiros dos princípios da Contrarreforma, estão condicionados por um forte componente filosófico de raiz platônica, ao considerar a preexistência de ideias sobre a realidade (o mito da caverna), e promovem, com isso um pensamento generalizador em favor do saber pelo saber. Em contraposição, a importância da teoria sobre a prática não ocorreu da mesma forma nos países de tradição calvinista, que com uma base filosófica aristotélica (matéria e forma 
são coisas reais) valorizaram, e ainda valorizam, a capacidade aplicativa do conhecimento. É bem conhecido o menosprezo de muitos membros da 'inteligência' de nossas sociedades latinas ao suposto 'utilitarismo' do saber anglo-saxão. (ZABALA E ARNAU, 2010, p. 19).

Jonnaert, por sua vez, apresenta um histórico das diferentes linhas e abordagens anglo-saxãs como observadas nos Estados Unidos (EUA). Esse histórico inicia com uma abordagem mais comportamentalista, que privilegiaria o desenvolvimento de técnicas e ações práticas, porém que carecem de reflexão. A partir dessa abordagem se desenvolve uma abordagem mais cognitiva e finalizando com uma abordagem por situação. Para Jonnaert as duas primeiras abordagens embora essencialmente opostas, assemelham-se pela instituição de uma numerosa lista de objetivos ou competências com características normativas e que não permitiria o desenvolvimento das competências de fato. Contudo, o autor indica que a abordagem centrada nas situações torna impraticável esse tipo de listagem prévia, pois essa prática descaracterizaria as competências e cita Anderson (1986) que chega à conclusão de que "não existe praticamente nenhum procedimento de validação experimental das competências" (JONNAERT, 2009).

\subsubsection{Avaliação das competências}

Do ponto de vista de um ensino tradicional, o que parece óbvio como sequência de ação do professor, é que se ensine os pontos específicos do conteúdo em sala de aula e ao fim de um determinado tempo ou de certa quantidade de conteúdo ministrado, faça-se uma verificação do aprendizado, o que, para o ensino tradicional de forma geral, significa fazer uma prova. Isto é, o aluno precisa de tempos em tempos "provar" que os conteúdos ministrados pelo professor podem ser por ele reproduzidos. É senso comum que, no ensino tradicional, o aluno é avaliado por meio de uma prova de conhecimentos. $O$ modelo dessa prova pode ser dissertativa, quando o aluno precisa apresentar 0 desenvolvimento e os passos por ele empregados para chegar à resposta 
correta, ou objetiva ${ }^{10}$, quando após um enunciado são apresentadas opções de respostas e o aluno deve selecionar aquela que julga correta.

Alguns exames de larga escala como o Exame Nacional do Ensino Médio (ENEM) e o Sistema de Avaliação da Educação Básica (SAEB) utilizamse de questões objetivas para testar o conhecimento dos estudantes. Como será discutido mais detalhadamente no capítulo 5, o objetivo inicial desses exames era não só avaliar os estudantes, mas o sistema educacional em si ${ }^{11}$. Tanto o ENEM quanto o SAEB possuem matrizes de competências e habilidades de acordo com as quais o estudante é avaliado. Cada item ${ }^{12}$ é classificado de acordo com uma competência e o acerto ou erro do estudante deve dar indícios da presença ou ausência da competência em questão.

Tem-se, portanto, uma ferramenta avaliativa fortemente relacionada ao ensino tradicional sendo utilizada na tentativa de avaliar e ranquear as competências de um sujeito. Procuraremos identificar as falas dos autores apresentados quanto a avaliação das competências, na tentativa de refletir sobre quais seriam suas propostas a respeito de como avaliar as competências.

Para Luckesi (2000) a mentalidade de examinar diverge da mentalidade de avaliar, embora o instrumento utilizado possa ser o mesmo em cada uma dessas disposições mentais. Para este autor, aquele que pratica exames não pratica avaliação, pois o exame tem por característica selecionar e excluir, enquanto que a avaliação pretende acolher e construir redirecionamentos, a partir de informações obtidas com os instrumentos.

Contudo para direcionar, adequar, replanejar ou saber se seus objetivos estão sendo alcançados, é forçoso que professores avaliem o desenvolvimento de competência nos sujeitos. De acordo com Luckesi (2000) "bons instrumentos de avaliação da aprendizagem são condições de uma

${ }^{10}$ É certo que existem diversos outros formatos de questões tais como: questão de somatória, completar espaços em branco, verdadeiro ou falso. Contudo os formatos dissertativo e objetivo são os mais utilizados e aqueles cuja discussão interessa neste trabalho.

${ }^{11}$ Esse caráter de avaliação do sistema educacional se revela no próprio nome dos programas, já que O Exame é DO Ensino Médio e a Avaliação é DA Educação Básica.

${ }^{12}$ Nesses exames, as questões são denominadas itens, nomenclatura relacionada à Teoria de Resposta ao Item (TRI) utilizada para atribuir pontuação aos testes. 
prática satisfatória de avaliação na escola." Nesse sentido cabe perguntar quais seriam os melhores instrumentos para avaliar competências.

A OCDE entende que uma das razões para a não promoção das competências de forma sistêmica seja a dificuldade dos sistemas de ensino estabelecerem formas de avaliar o seu desenvolvimento (LANCRIN, 2018)

Para Perrenoud (1999) "a avaliação das competências encontra dificuldades conceituais e técnicas", o que não significa que não devam ser avaliadas, mas que o processo de avaliação não pode ser banalizado. $O$ autor destaca que a avaliação fornece um feedback, que pode partir do professor, de um colega mas principalmente dos próprios obstáculos impostos pela realidade no lidar com situações reais. Portanto a avaliação da competência deve acontecer em conjunto com seu desenvolvimento, ou seja, em contexto, pois "uma avaliação centrada em conhecimentos descontextualizados arruinaria qualquer abordagem por competências" (PERRENOUD, 2009, p. 66).

Exames como o ENEM, ou mesmo provas internas feitas no mesmo molde, são padronizados por ao menos três motivos. O primeiro diz respeito à correção dos testes, que deve ser facilitada na medida em que aumenta o número de sujeitos que realizam tal exame. O segundo motivo é que, em tese, teste padronizados estariam atendendo ao princípio de isonomia, no qual todos os sujeitos têm o direito de ser avaliados sob os mesmos critérios e tendo acesso às mesmas condições. Discute-se, contudo, se a padronização de fato garante o princípio de isonomia ou se ao contrário, reforça desigualdades (BASSO, 2017). O terceiro motivo para a padronização é garantir a comparabilidade dos resultados, isto é, ser possível que se faça um ranking de sujeitos de acordo com sua pontuação no exame. Este ranqueamento pode se estender para os estados, cidades, escolas e professores. A comparabilidade, em tese, também seria importante do ponto de vista estatístico para fazer a checagem de resultados ou a proposta de novas políticas públicas para a melhoria da educação.

A padronização parece, portanto, tornar o exame funcional, mas para Perrenoud não ajuda para que se avaliem competências, sobretudo do ponto de vista de comparação, pois seria "impossível comparar as classes em razão da diversidade dos contextos, do número e do nível dos alunos ao entrar na 
escola e em uma determinada classe, da composição social e étnica do público, do número e da natureza dos casos particulares." (PERRENOUD, 1998). Além disso, como apresentado anteriormente, para Perrenoud e os outros autores apresentados neste capítulo, o ensino por competências tem como importante ponto de apoio o enfrentamento de situações em contexto, e situações que façam parte do cotidiano real dos estudantes, dessa forma a padronização de situações para o ensino e avaliação seria praticamente impossível.

À ideia de avaliar os resultados obtidos pelos professores em termos das aquisições de seus alunos, opõe-se facilmente um argumento clássico: seria impossível comparar as classes em razão da diversidade dos contextos, do número e do nível dos alunos ao entrar na escola e em uma determinada classe, da composição social e étnica do público, do número e da natureza dos casos particulares. (PERRENOUD, 1999)

Contudo, é importante ressaltar que Perrenoud não é contrário à avaliação das competências. $O$ autor defende inclusive a autonomia dos professores com relação às ferramentas a serem escolhidas para que se realize a avaliação de competências de maneira mais adequada.

Quanto mais o sistema educativo restringe a autonomia dos professores quanto à escolha de métodos e meios de ensino e avaliação, mais ele limita suas responsabilidades, acentuando o que se pode chamar de uma proletarização ou uma desprofissionalização de seu trabalho, em suma, aumentando uma dependência com respeito às regras concebidas pela hierarquia ou pelos especialistas (PERRENOUD, 1994 a, 1996 e).

É preciso, portanto, pensar em novas formas de avaliar e assumir uma nova postura com relação ao papel da avaliação na formação dos estudantes. Para tanto, Perrenoud (1999) apresenta seis pontos a serem observados e que apresentaremos resumidamente aqui.

1- O professor precisa abrir mão do uso da avaliação como meio de pressão e de barganha.

2- Adotar uma postura de observar em situação com o objetivo de formar o aluno e não fazer com que este seja bem-sucedido nas tarefas particulares da avaliação. 
3- Aceitar as competências coletivas, abandonando um espiríto de justiça e controle ao tentar calcular contribuições individuais em situações coletivas.

4- Desistir de padronizar a avaliação.

5- Saber criar situações de avaliação que certifiquem competências.

6- Envolver os alunos na avaliação de suas competências por meio de debates e favorecendo avaliações mútuas e auto-avaliações.

São explorados dois tipos de avaliação. A avaliação formativa acontece ao longo do processo de desenvolvimento das competências e fornece aos alunos e alunas informações que lhes permitem corrigir percursos no sentido de obter os melhores resultados. A avaliação certificativa verifica se determinada competência foi desenvolvida. Embora de naturezas distintas, ambas as avaliações devem ocorrer em situação.

Com base nisso Perrenoud afirma que "a avaliação das competências não pode ser senão complexa, personalizada e imbricada no trabalho de formação propriamente dito." (PERRENOUD, 1999).

A abordagem de Zabala e Arnau (2010) é mais detalhada, apresentando e discutindo os componentes da estrutura da avaliação de forma geral e da avaliação por competências. O autor inicia a discussão colocando de maneira muito clara que pensar em uma avaliação da aprendizagem de competências significa revisar aquilo que está relacionado a esta competência. A avaliação deve "se dirigir a todo o processo de ensino e aprendizagem" (ZABALA e ARNAU, 2010, p.169), dessa forma não faz sentido uma avaliação preocupada somente com o resultado obtido pelo aluno. Isto é, a avaliação deve atentar para todos as variáveis do processo de aprendizagem, Zabala e Arnau apontam três: as atividades, as experiências e os conteúdos. Dessa forma para o autor a avaliação não pode ser um processo simplista, mas se a escola "entender a avaliação como um processo no qual [não] apenas se analisa a aprendizagem dos alunos, mas também as atividades de ensino significa incrementar notavelmente a complexidade dos meios e as estratégias para conhecer uma unidade de intervenção pedagógica e as consequências de todas as ações que nela ocorrem." Ou seja, avaliar, para Zabala e Arnau, é mais do que uma verificação da aquisição de determinado conteúdo (ou 
mesmo competência) por parte do aluno, mas deve também considerar as dimensões de práticas, metodologias e estratégias utilizadas pela escola e pelo professor.

O autor faz uma crítica à redução do processo de avaliação somente à aplicação de provas escritas (objetivas ou dissertativas). Segundo ele, essa redução tem caráter seletivo que converte de maneira simplista as capacidades dos estudantes em uma pontuação que Ihes confere triunfo ou fracasso em um caminho que em geral conduz à universidade, deixando de atender àqueles que não podem ou não desejam trilhar esse caminho (ZABALA E ARNAU, 2010).

Zabala e Arnau não defendem o banimento da prova escrita, seja ela objetiva ou dissertativa. Assim como foi discutida com relação ao saber cognitivo e à disciplinarização, a crítica dos autores é sobre a redução dos possíveis métodos de avaliação a apenas um, que de maneira limitada seleciona alunos com base em apenas parte de suas caraterísticas e capacidades. Essa redução está também relacionada a um ensino tradicional, em que os saberes cognitivos são enfatizados, portanto cobrados em avaliações padronizadas, em detrimento de outros saberes.

Os autores apresenta os diferentes saberes em relação ao modelo avaliativo de provas escritas. Para ele quando se quer verificar o conhecimento do aluno sobre conteúdos factuais a pergunta simples e direta, muito relacionada a esse tipo de prova, é uma estratégia muito apropriada. Contudo, se o que se deseja é compreender o grau de aprendizagem de um conteúdo conceitual, o aluno até pode ser avaliado com base em uma prova escrita, mas as questões devem conter conflitos mais complexos com dados não tão evidentes para uma simples operacionalização.

Quanto à avaliação de saberes procedimentais (saber-fazer) as provas escritas são demasiadamente limitadas e outras formas mais adequadas de avaliação deveriam ser buscadas. O maior problema está relacionado aos saberes atitudinais (saber-ser), cuja avaliação por meio de provas escritas, segundo Zabala e Arnau, é "totalmente inútil” (ZABALA E ARNAU, 2010).

Zabala e Arnau citam avaliações de organizações internacionais tais como a Organização para Cooperação e Desenvolvimento Econômico (OCDE) 
para o Programa Internacional de Avaliação de Alunos (PISA), que apesar de seu prestígio em ações ligadas à educação, estão restritas à avaliações escritas. O autor destaca também que essas provas tendem à influenciar as grades curriculares das escolas, que preparam seus estudantes, muitas vezes, com base naquilo que pode vir a ser cobrado em alguns desses exames, fazendo com que o objetivo daquilo que se deseja avaliar, seja subordinado ao método avaliativo e não o contrário, como seria de se esperar. Em comparação, no Brasil vale citar novamente o ENEM e o SAEB, que apesar de possuírem uma grade de competências são uma prova escrita e padronizada, situação que voltaremos a discutir adiante.

Feita a crítica com relação à restrição das avaliações à prova escrita, Zabala e Arnau discutem a avaliação da aprendizagem de competências. Os autores apresenta uma problemática com relação a este tipo de avaliação:

Dado que a competência se define como a resposta eficiente diante de uma situação real, palpável e em um lugar e momento determinados, podemos concluir facilmente que a avaliação de competências, propriamente dita, é impossível se não se realiza no mesmo momento em que a circunstância apresentada exige ser competente. (ZABALA E ARNAU, 2010, p. 173)

É interessante notar que Zabala e Arnau não impossibilitam a avaliação das competências, mas assim como o processo de ensino-aprendizagem, esta avaliação se dá de forma complexa, considerando diversas dimensões e não pode estar desvinculada de uma situação real, ou muito próxima da realidade.

Para Zabala e Arnau o que precisa primeiro ser estabelecido é: qual o objetivo da avaliação das competências, considerando apenas a avaliação do aluno e não as outras dimensões citadas do processo educativo. Uma das possibilidades é que o objetivo seja o de conhecer a capacidade dos alunos e neste sentido bastaria que a avaliação considerasse apenas o resultado da situação apresentada. Outra possibilidade é a de que o objetivo da avaliação seja evidenciar os pontos de limitações dos alunos, para assim conseguir traçar estratégias de intervenção de modo a ajudá-lo a superar suas dificuldades.

De acordo com Zabala e Arnau a chave para a avaliação de competências está em "estabelecer a situação-problema" que deve ter em si, como possibilidade de resolução, os esquemas que se espera observar e que 
podem então evidenciar a presença de determinadas competências no tratamento dessa situação. Ele argumenta que "quando decidimos que queremos avaliar competências, estamos dizendo que reconheceremos a capacidade que um aluno adquiriu para responder a situações mais ou menos reais, problemas ou questões que têm muitas probabilidades de chegar a encontrar, embora seja evidente que nunca do mesmo modo em que foram aprendidos." (ZABALA E ARNAU, 2010, p. 174). Ou seja, as situaçõesproblema propostas aos estudantes, sobretudo no que diz respeito à avaliação, devem ter forte relação com a realidade, simulando-a de modo convincente ou ao menos coerente. Embora não se espere que situações reais sejam absolutamente iguais àquelas propostas nas atividades e avaliações escolares, também faz parte da competência desenvolvida que o sujeito seja capaz de transpor conhecimentos e recursos específicos para situações parecidas, mas considerando suas peculiaridades como discutido anteriormente.

Esse tipo de procedimento é muito parecido com aquilo que se encontra em algumas formações profissionais específicas. Bombeiros em treinamentos de resgate, policiais em exercícios para grandes eventos, negociadores de reféns exercitando argumentação, jogadores de futebol treinando jogadas ensaiadas; esses são exemplos de profissões para as quais, os treinamentos, simulam situações o mais fielmente possível, não esperando que as situações de fato reais sejam exatamente iguais, mas desenvolvendo nos sujeitos competências para que, com algumas adaptações, possam agir de maneira eficaz diante de situações críticas a serem enfrentar de fato no dia-adia. A crítica de Zabala e Arnau às provas escritas se evidencia nesse ponto, pois, mesmo que as questões de um teste padronizado façam referência a um contexto real, o estudante não está tendo aquela vivência.

Zabala e Arnau apresentam tópicos conclusivos sobre sua análise em relação à avaliação das competências, dos quais serão apresentados a seguir apenas alguns pontos, como um recorte daquilo que se julga mais relevante para esta discussão. De acordo com o autor:

- As atividades dirigidas a conhecer o processo e os resultados da aprendizagem devem corresponder aos meios para 
responderem a uma situação-problema a qual possa ser entendida como real.

- A simples exposição do conhecimento que um aluno tem sobre um assunto e a capacidade de resolver problemas estereotipados não são estratégias avaliativas apropriadas para a avaliação de competências.

- As provas escritas fornecem uma informação muito limitada para a maioria das competências.

- A informação para a avaliação de competências não deve limitar-se ao conhecimento adquirido em provas, mas ser 0 resultado da observação das atividades de aula.

- Os conteúdos dos programas devem se referir explicitamente às competências gerais.

Como apresentado, um ponto de convergência entre os autores é que, organizar currículos por competências, inclusive pensando naquilo que se avaliará, exige uma reflexão inicial sobre o tipo de cidadão que se deseja formar, ou de maneira mais ampla, em que tipo de sociedade se deseja viver, para que as competências necessárias para os membros dessa sociedade possam então ser desenvolvidas e avaliadas ao longo do processo educativo.

O quadro a seguir apresenta, de forma resumida, a sistematização que procuramos fazer nesta seção.

\begin{tabular}{|c|c|c|c|}
\hline & Philippe Perrenoud & Philippe Jonnaert et al. & Antoni Zabala e Laia Arnau \\
\hline $\begin{array}{l}\text { Situação ou } \\
\text { Contexto }\end{array}$ & $\begin{array}{l}\text { As competências } \\
\text { desenvolvidas em } \\
\text { uma situação, } \\
\text { possibilitam ao sujeito } \\
\text { atuação competente } \\
\text { em uma família de } \\
\text { situações } \\
\text { semelhantes. }\end{array}$ & $\begin{array}{c}\text { A situação é o } \\
\text { primeiro e mais } \\
\text { impotente elemento } \\
\text { pois permite a } \\
\text { manifestação e } \\
\text { desenvolvimento da } \\
\text { competência. Os } \\
\text { programas de ensino } \\
\text { deveriam ser } \\
\text { propostos com base } \\
\text { em situações. }\end{array}$ & $\begin{array}{l}\text { O ensino por competências } \\
\text { deve propor o } \\
\text { enfrentamento de situações } \\
\text { reais pelos alunos, pois as } \\
\text { competências se } \\
\text { desenvolvem em sinergia } \\
\text { com a situação. }\end{array}$ \\
\hline
\end{tabular}


Quadro 2.1.- Perspectivas dos teóricos a respeito dos sentidos das competências em relação a conceitos específicos relacionados à arquitetura das competências.

\begin{tabular}{|c|c|c|c|}
\hline & Philippe Perrenoud & Philippe Jonnaert et al. & Antoni Zabala e Laia Arnau \\
\hline $\begin{array}{l}\text { Transferência } \\
\text { e mobilização } \\
\text { de recursos }\end{array}$ & $\begin{array}{l}\text { Ênfase nos recursos } \\
\text { cognitivos que são } \\
\text { mobilizados entre } \\
\text { áreas de } \\
\text { conhecimento. A } \\
\text { constituição de } \\
\text { esquemas de } \\
\text { mobilização permite o } \\
\text { tratamento eficaz das } \\
\text { situações. }\end{array}$ & $\begin{array}{l}\text { Redes operatórias } \\
\text { permitem uma } \\
\text { mobilização ordenada } \\
\text { e reflexiva de recursos } \\
\text { para produzir uma } \\
\text { resposta eficaz às } \\
\text { situações enfrentadas. } \\
\text { Considera recursos } \\
\text { cognitivos, materiais e } \\
\text { de outras naturezas. }\end{array}$ & $\begin{array}{c}\text { Não utiliza o termo } \\
\text { "mobilização", mas } \\
\text { "esquemas de atuação", } \\
\text { que pressupõe a articulação } \\
\text { coordenada daquilo que } \\
\text { permitira ao sujeito fornecer } \\
\text { uma resposta eficaz à } \\
\text { situação. }\end{array}$ \\
\hline Saberes & $\begin{array}{l}\text { Enfatiza o termo } \\
\text { Savoir-faire (saber- } \\
\text { fazer), isto é, a } \\
\text { articulação de } \\
\text { conteúdos } \\
\text { disciplinares ou não } \\
\text { disciplinares que } \\
\text { permitem ao sujeito a } \\
\text { resolução de uma } \\
\text { família de situações. } \\
\text { Não defende o fim } \\
\text { das disciplinas no } \\
\text { ensino. }\end{array}$ & $\begin{array}{c}\text { Os saberes } \\
\text { ultrapassam a esfera } \\
\text { cognitiva } \\
\text { considerando também } \\
\text { os saberes } \\
\text { relacionados à } \\
\text { emoção, vontade, } \\
\text { atitudes e interações. } \\
\text { Não defende o fim das } \\
\text { disciplinas no ensino. }\end{array}$ & $\begin{array}{l}\text { Considera três grandes } \\
\text { domínios; o saber } \\
\text { (conceitual) o saber-ser } \\
\text { (atitudinal) e o saber-fazer } \\
\text { (procedimental). } \\
\text { Não defende o fim das } \\
\text { disciplinas no ensino. }\end{array}$ \\
\hline Avaliação & $\begin{array}{l}\text { Avaliar competências } \\
\text { é difícil do ponto de } \\
\text { vista conceitual e } \\
\text { técnico, o que não } \\
\text { significa que não } \\
\text { devam ser avaliadas. } \\
\text { A avaliação das } \\
\text { competências deve } \\
\text { acontecer em } \\
\text { conjunto com seu } \\
\text { desenvolvimento. } \\
\text { Deve-se desistir da } \\
\text { padronização das } \\
\text { avaliações. }\end{array}$ & $\begin{array}{c}\text { No texto analisado o } \\
\text { autor não discute a } \\
\text { avaliação de } \\
\text { competências. }\end{array}$ & $\begin{array}{l}\text { A avaliação deve se dirigir } \\
\text { ao processo de ensino- } \\
\text { aprendizagem como um } \\
\text { todo, não estar preocupada } \\
\text { apenas com o resultado. } \\
\text { Não deve ser reduzida } \\
\text { apenas à aplicação de } \\
\text { provas objetivas ou } \\
\text { dissertativas. A avaliação } \\
\text { deve acontecer na } \\
\text { resolução da situação. A } \\
\text { chave da avaliação está no } \\
\text { estabelecimento da situação } \\
\text { problema. }\end{array}$ \\
\hline
\end{tabular}

Fonte: Elaborado pelo Autor. 


\section{UMA VISÃO GERAL DE CURRÍCULO}

A palavra Currículo tem origem no termo Curriculum do latim, que significa "curso de vida" (DE LANDDSHEERE, 1991, como citado em JONNAERT et al, 2010). Este curso de vida pode referir-se àquilo que passou, no caso de currículos que são enviados para candidatura a alguma função, ou na apresentação de palestrantes. Mas é interessante para este trabalho a concepção de currículo que indica o futuro e que está intimamente relacionada com a área de educação.

No Brasil, a discussão sobre o currículo está em destaque devido à homologação da Base Nacional Comum Curricular (BNCC), para o ensino infantil e o ensino fundamental, em 20 de Dezembro de 2017, o que obriga instituições a adequações em seus programas de ensino. Por isso, a discussão geral a respeito do currículo é de grande importância. 
Primeiramente será feito um panorama sobre as noções gerais de currículos e apresentadas algumas considerações específicas com base em Jonnaert, Ettayebi e Defise (2010). Depois serão discutidos alguns aspectos gerais do que seria um currículo por competência e qual relação pode existir entre esses dois conceitos.

\subsection{Currículo: perspectivas e visões}

De acordo com Lopes (2008) é possível destacar duas abordagens básicas para o currículo. Na primeira, uma abordagem clássica, o currículo apresenta os conteúdos em uma sequência linear, considerando séries e arranjos disciplinares. A segunda, uma abordagem crítica, essa linearidade e a obrigatoriedade de se conceber determinados conteúdos nessa sequência, são profundamente questionados.

A autora compara os dois tipos de currículo com escolas literárias distintas. A concepção clássica estaria relacionada com romances lineares, típicos do século $\mathrm{XIX}$, que para serem compreendidos em sua totalidade, precisariam ser lidos de acordo com a sequência pensada e apresentada pelo autor. A concepção crítica poderia ser comparada com as narrativas "desmontáveis", típicas do século XX, nas quais o leitor pode iniciar a leitura a partir de qualquer capítulo para ter o mesmo entendimento da obra. Neste caso, não há portanto um encadeamento rígido, mas uma independência da ordem, aliada à interrelação dos capítulos ou volumes publicados (LOPES, 2008).

Embora Lopes apresente duas formas de organização do currículo, sua definição inicial da conta de uma organização de conteúdos. Como aquilo que será aprendido deve ser organizado para tornar a aprendizagem mais eficaz. Jonnaert et al (2010) ampliam esta compreensão quando apresentam a ideia de programa de ensino subordinado ao currículo.

Ao descrever a onda mundial de renovação curricular observada na época da produção da obra (2009), os autores discutem o desenvolvimento de uma teoria do currículo e afirmam que "tal teoria vai muito além das simples questões de reelaboração dos programas de ensino" (JONNAERT et al, 2010) 
função que estaria a cargo dos programas de ensino. De acordo com Strauven (2006) como citado por Jonnaert et al (2010)

[...] um currículo é um plano de ação. Ele é inspirado pelos valores que uma sociedade deseja promover; esses valores se expressam nas finalidades atribuídas ao conjunto do sistema de educação. $O$ currículo oferece uma visão de conjunto planejada, estruturada e coerente das diretivas pedagógicas para organizar e gerir a aprendizagem em função dos resultados almejados (JONNAERT et al, 2010, p. 17).

Dessa forma, para estes autores, o currículo deve carregar as características gerais sobre os resultados da educação que a sociedade deseja, subordinando assim os programas de ensino por mais diversos que sejam.

Segundo os autores, inverter a hierarquia entre currículo e programas de ensino provoca incoerências básicas nos conceitos que definem esses programas causando distorções. Para eles confundir currículo com o programa, implica em uma confusão entre fins e meios (JONNAERT et al, 2010). Quando essa confusão ocorre

[...] em certas formações gerais, definidas exclusivamente por meio dos programas disciplinares, áreas inteiras de aprendizagem, como aquelas relativas às artes, às ciências sociais ou, ainda, à educação física, são marginalizadas, ao passo que as áreas da matemática, das ciências e da tecnologia, bem como as das línguas ocupam todo o espaço e orientam o conjunto da formação (JONNAERT et al, 2010, p. 32).

Uma importante característica do currículo apresentada pelos autores é sua flexibilidade, pois este deve se adaptar às necessidades sociais específicas em relação à localização das unidades de ensino (JONNAERT et al. 2010). No caso do Brasil, país de dimensões continentais, enormes diferenças sociais e inúmeras especificidades regionais, seria, portanto, necessário que o currículo geral apresentasse bases de unidade para o que os programas de ensino locais pudessem oferecer aos estudantes ${ }^{13}$.

${ }^{13}$ A BNCC homologada indica que $60 \%$ do currículo deve ser comum a todo o Brasil e $40 \%$ deverão atender às demandas locais. Não está claro como deve se dar essa diferenciação. Este tema será discutido mais detidamente no capítulo 4. 
De acordo com os autores, existem numerosas definições para currículo, em seu texto destacam duas correntes que são também importantes para este trabalho. É feita uma diferenciação entre a corrente anglo-saxã e a corrente franco-européia para o currículo.

Para os autores, os anglo-saxões fornecem para o currículo a visão mais ampla apresentada anteriormente, ultrapassando a ideia de programa de ensino, centrando o ensino no estudante buscando fornecer aplicabilidade para o que se ensina, pois se busca "a integração social do sujeito" ${ }^{14}$ (JONNAERT et al, 2010). Por outro lado, na corrente franco-européia "o currículo designa a programação dos conteúdos de ensino ao longo da escolaridade" (JONNAERT, et al, 2010, p. 29).

Essa visão, portanto, apresenta aquilo que os autores chamaram de "confusão entre currículo e planos de ensino", e esses dois elementos se sobrepõem dando ao currículo franco-europeu um caráter mais rígido, linear e que em alguns momentos perde conexão com as necessidades do estudante.

A definição do que compõe o currículo não é tarefa trivial sendo que diversas podem ser as abordagens e visões a esse respeito. Lopes e Macedo (2011) apresentam um importante panorama a respeito dessas visões a partir de autores como Bobbitt, com uma visão de currículo eficiente ou Dewey que defende um currículo mais progressista.

As discussões também podem se dar em torno de como o currículo é organizado ou quais são seus objetivos. É possível pensar no currículo como prescritivo, que seleciona apenas o que é ensinado como uma ponte para o desenvolvimento do sujeito, reforçando a reprodução dos conhecimentos e das relações sociais reconhecidas como ideais pelo currículo. Esta visão é relacionada pelas autoras com a escola tradicional jesuítica (LOPES e MACEDO, 2011).

Por outro lado o currículo pode ser encarado como um instrumento de "contraposição à reprodução" buscando na vida e na importância do indivíduo

${ }^{14}$ A compreensão anglo-saxã de currículo será de grande importância quando for apresentada a noção de currículo por competência e ainda mais no capítulo 2 quando forem discutidos os elementos que estruturam uma competência. 
despertar sua consciência e critica social, como defendido por Freire (LOPES e MACEDO, 2011).

De maneira geral, a questão que se apresenta, é que a ideia de currículo como uma listagem prescritiva de conteúdos a serem ensinados aos alunos, não comporta toda a complexidade do significado de currículo se forem consideradas as abordagens e níveis de influência possíveis. Na perspectiva de Lopes e Macedo (2011, p.36)

Ainda que muito diferente em suas concepções teóricas, o conjunto de abordagens que destacamos aqui explicita o quanto a noção de currículo formal é insuficiente para dar conta da multiplicidade de experiências - internas e externas aos sujeitos, individuais e coletivas - que compõe o currículo. Em realidade, os autores que destacamos buscam reconceptualizar o currículo, abandonar, portanto, as perspectivas técnicas para criar uma nova forma de pensar o currículo. Pretendem superar a ideia de que o currículo é algo formal ou escrito a ser implementado numa realidade escolar. [...] o currículo é o proposto no nível formal, mas também o vivido no cotidiano.

Pensando nessa complexidade, as autoras apontam três diferentes níveis de currículo. O nível que diz respeito aos documentos oficiais e currículos prescritos, ao o que chamam de currículo formal. O nível dos elementos que influenciam no aprendizado de maneira não declarada, como relações de poder e ações esperadas em determinadas situações. Elementos que embora conhecidos como regra geral, não são prescritos. A esse nível, as autoras chamam currículo oculto. E por fim o currículo vivido coloca em prática aquilo que foi prescrito no currículo formal. Claro que não de maneira completa e literal, mas considerando o que é possível desenvolver em cada realidade local. No texto consta, em seguida, uma desconstrução dessas diferenciações com base na discussão sobre uma postura realista e antirealista do currículo. Isto é, o currículo descreve a realidade, ou cria a realidade, dando sentido às relações conforme procura descrevê-las? As autoras concluem que

O entendimento do currículo como prática de significação, como criação ou enunciação de sentidos, torna inócua distinções como currículo formal, vivido, oculto. (LOPES e MACEDO, 2011). 
Isto é, as autoras procuram pensar o currículo de uma maneira não estrutural, fazendo com que as distinções percam sentido, embora se entenda a influencia do currículo ao longo de todo o processo educativo.

Para um melhor entendimento dos capítulos subsequentes deste trabalho, é interessante que se mantenha em mente uma dimensão estrutural do currículo. Não adotaremos qualquer nomenclatura a respeito dos níveis do currículo em que os sentidos das competências estão sendo investigados. Contudo, é feita uma clara distinção de nível de abrangência quando discutimos as competências no Nível de Regulamentação e no Nível de Orientação Didática, por exemplo, e em cada um dos níveis verticais apresentados no capítulo 1.

\subsection{O currículo pode ser por competências?}

O Exame do Ensino Médio (ENEM) desde sua concepção apresenta uma matriz de competências e habilidades, segundo a qual o estudante deve ser avaliado. A fundamentação teórico-metodológica do exame enfatiza a ideia do desenvolvimento de competências. Diante de um exame que avalie o desenvolvimento de competências, é preciso questionar se o ensino se deu com base nessas competências para que seu desenvolvimento possa ser então avaliado. É preciso, portanto, que o currículo adotado pelo sistema como um todo e nas instituições de ensino, seja de fato orientado por competências.

A ênfase em competências no desenvolvimento de currículos tem sido tema de interesse de organizações globais. A Organização para a Cooperação de Desenvolvimento Econômico (OCDE) tem publicado relatórios que enfatizam um ensino focado no desenvolvimento de competências

Crianças originárias de um contexto de baixa renda podem se beneficiar do acesso à aprendizagem digital que inclua softwares interativos e bem projetados para o desenvolvimento de habilidades juntamente a um currículo baseado em competências. (tradução nossa). ${ }^{15}$ (OECD, 2014, p. 294)

Um estudo encomendado para este Relatório destaca até que ponto os países estão enfatizando a necessidade de tais habilidades

\footnotetext{
${ }^{15}$ Children from low income backgrounds can benefit from access to computer-aided learning that includes well-designed interactive software supporting skills development, alongside curriculum-based competencies.
} 
transferíveis em seus currículos nacionais. Comunicação e competência social foram as mais evidentes: dentre 88 países, 71 incluem essas qualidades em seus currículos. A ênfase também é colocada na resolução de problemas (em 55 países), criatividade (52) e uso de TIC (51). Cerca de metade dos países incorpora competência cívica, colaboração, pensamento crítico e empreendedorismo nos seus quadros curriculares e documentos (tradução nossa). ${ }^{16}$ (AMADIO, 2013, p.295).

Também a Organização das Nações Unidas para a Educação Ciência e Cultura (UNESCO) apresenta um posicionamento no qual se deve um "ensino e aprendizagem para a paz por meio da pedagogia, do currículo e de materiais transformadores, o que deve promover construção de competências para cidadania responsável" (UNESCO, 2015).

A ideia de um currículo organizado por competências não é trivial. Lopes (2008) afirma que

o currículo por competências não expressa um potencial crítico. Ao contrário, revela-se um pensamento conformista, na medida em que não tem por princípio focalizar como é possível à escola questionar o modelo de sociedade no qual está inserida. (LOPES, 2008, p. 68).

No entendimento da autora, o conceito de competência, e, sobretudo um currículo por competências, estaria à serviço do mundo produtivo, atendendo às demandas de mercado.

É feita uma associação do currículo por competência com os objetivos de uma pedagogia comportamentalista, o que, segundo a autora, dá a esse conceito um "forte enfoque instrumental" (LOPES, 2008).

Enquanto Lopes (2008) entende que o currículo por competências tem caráter rígido, uma vez que, associado à objetivos comportamentais, deve ter esses objetivos definidos de forma precisa, Jonnaert et al (2010) entende que as competências são "um objeto muito pouco curricular" uma vez que existe uma dificuldade em se definir uma listagem de competências a priori. Dessa

\footnotetext{
16 A study commissioned for this Report highlights the extent to which countries are emphasizing the need for such transferable skills in their national curricula. Communication and social competence were the most evident: among 88 countries, 71 include these qualities in their curricula. Emphasis is also placed on problem-solving (in 55 countries), creativity (52) and ICT use (51). About half the countries incorporate civic competence, collaboration, critical thinking and entrepreneurship in their curriculum frameworks and policy documents

${ }^{17}$ Enfase deste autor.
} 
forma a noção de competência tenderia a orientar a ação dos alunos no processo de ensino e não a prescrever percursos.

Jonnaert et al (2010) se opõem à ideia de que um currículo por competências possa ser associado de maneira direta com uma pedagogia por objetivos. Para eles

A organização dos conteúdos por objetivos [...] é o antípoda da abordagem situada ${ }^{18}$. A observação da construção de uma competência por uma pessoa em ação em uma situação permite ter consciência de que a organização dos conteúdos por objetivos só traz, no máximo, uma parcela de recursos úteis ao tratamento competente de uma situação, nada além disso" (JONNAERT et al, 2010, p. 77).

Semelhantemente ao que acontece com o currículo, as competências podem ser encaradas a partir de diversas perspectivas, ou diversas lógicas. Se o currículo possui diversos níveis, ou âmbitos, e se é discutida a possibilidade de que se desenvolva um currículo por competências, é importante que essas competências sejam pensadas em cada um desses âmbitos ou níveis do currículo.

Para Jonnaert et al (2010) as competências podem ser pensadas a partir de três lógicas: a Lógica da ação em situação, a Lógica curricular e a Lógica da aprendizagem.

No primeiro caso, a competência se constrói a partir da ação do sujeito em situação, o que os autores chamam de Competência Atuacionista.

A Lógica curricular se revela quando a competência precisa ser descrita como uma finalidade atrelada a um conteúdo de modo a formar os programas de ensino, nos quais se desenvolve a Competência Curricular.

E por fim, a Lógica da aprendizagem diz respeito aos "percursos de aprendizagem" em sala de aula, isto é, as estratégias, atividades e materiais que serão utilizados visando a construção da Competência Construída.

${ }^{18}$ A abordagem situada leva em consideração a noção de Jonnaert e de outros autores, de que uma competência só pode ser definida em uma situação real. Portanto não bastaria um objetivo comportamental para que se estabelecesse uma competência, seria preciso uma situação real, que exigisse uma intervenção eficaz do estudante. As características das competências serão melhor exploradas no capítulo 2. Ênfase do autor. 
Embora a perspectiva que discute lógicas tão diferentes para as competências seja de grande importância, neste trabalho não utilizaremos essas nomenclaturas para nos referirmos às competências nos diferentes níveis verticais. Nem mesmo assumiremos competências específicas para cada nível. Nossa perspectiva é a de investigar mudanças nos sentidos das competências em diferentes âmbitos. Dessa forma, nosso objetivo não está em investigar diversos tipos de competências, mas sim dispensar atenção às transformações nos sentidos das competências de acordo com o âmbito em que elas se encontram.

Nos capítulos seguintes procuraremos investigar os sentidos das competências em diferentes níveis do currículo do sistema de ensino brasileiro.

Do ponto de vista do currículo adotaremos uma perspectiva estruturada, que observa o currículo como um todo, mas destaca os seus vários níveis de manifestação.

Para as competências adotaremos uma visão unificada, buscando investigar as possíveis mudanças nos sentidos atribuídos às competências nos diferentes níveis do currículo. 


\section{AS COMPETÊNCIAS NOS DOCUMENTOS OFICIAIS}

O desenvolvimento de uma teoria de currículo aponta visões a respeito do ensino. Essas visões não necessariamente são absorvidas por aqueles que trabalham diretamente em áreas educacionais, mesmo se, em tese, adotarem visão que concorde com determinada teoria. Há uma distância considerável entre aquilo que os diferentes autores buscaram estruturar, e aquilo que é interpretado ou mesmo aquilo que é factível, dentro de sua teoria. Além da dificuldade de interpretação e desenvolvimento prático da teoria, existem aspectos estruturais, culturais e sociais que não podem ser ignorados quando se pretende adotar determinada teoria.

As teorias curriculares que lidam com uso de competências devem, portanto, enfrentar o desafio de comunicar de forma clara o que se entende por competência, e quais ações podem ser, de fato, promovedoras de seu 
desenvolvimento. A comunicação clara do entendimento de uma teoria e as ações que promovem seu desenvolvimento são comunicadas por meio de documentos curriculares oficiais.

No Brasil, a discussão a respeito do currículo, centra-se atualmente no estabelecimento de uma Base Nacional Comum Curricular (BNCC). A ideia de estabelecer diretrizes e parâmetros de alcance nacional não é nova. Após a promulgação da LDB/96, são propostas as Diretrizes Curriculares Nacionais em 1998 como normas necessárias para a "implantação da nova estrutura de educação então instituída." (BRASIL, 2001, p. 5). No ano de 2000, foram publicados os Parâmetros Curriculares Nacionais (PCN) e seus complementos em 2002 ( $\mathrm{PCN}+)$. Os PCN e PCN+ visavam atender à demanda das DCN-1998 que, assim como a LDB/96, estabeleciam uma "formação básica comum" (BRASIL, 1997, p.14).

Modificações estruturais, tais como, o "Ensino Fundamental de nove anos e a obrigatoriedade do ensino gratuito dos quatro aos 17 anos de idade" (BRASIL, 2013, p. 4), levaram à promulgação, em 2012, de um documento atualizado de Diretrizes Curriculares Nacionais (DCN-2012). Semelhantemente às publicações anteriores, as novas diretrizes "estabelecem a base nacional comum, responsável por orientar a organização, articulação, o desenvolvimento e a avaliação das propostas pedagógicas de todas as redes de ensino brasileiras" (BRASIL, 2013, p. 4). No ano de 2015 foi divulgado um texto preliminar da BNCC em atendimento ao Plano Nacional de Educação (PNE), de 2014, e a demanda de uma formação comum estabelecidas na LDB/96 e nas DCN. A versão preliminar da BNCC foi alterada e republicada diversas vezes, até que em Dezembro de 2017 foi homologada sua versão oficial para o Ensino Infantil e para o Ensino Fundamental. E em Abril de 2018 foi divulgada a última, e ainda não definitiva, versão da BNCC para o Ensino Médio.

Este capítulo analisará a presença do conceito de competência em documentos curriculares oficiais. Na primeira parte será feita uma breve apresentação da LEI № 9.394, DE 20 DE DEZEMBRO DE 1996 ou Lei de Diretrizes e Bases (LDB). Serão então analisadas de maneira comparada as resoluções, Re. 3 de 26 de Junho de 1998 (DCN-1998) e Re. 2 de 30 de 
Janeiro de 2012 (DCN-2012), que tratam das definições das Diretrizes Curriculares Nacionais para o Ensino Médio nesses anos. Em seguida, a mesma comparação será feita entre os documentos curriculares, a saber, os Parâmetros Curriculares Nacionais (PCN) e a Base Nacional Comum Curricular (BNCC) para o Ensino Médio. A DCN-1998 apresenta, para o ensino em território nacional, diretrizes gerais que tomam forma nos PCN. As DCN-2012, por sua vez, são diretrizes para o desenvolvimento da BNCC. Portanto, embora a sequência cronológica da publicação dos documentos seja LDB/96, DCN1998, PCN, DCN-2012, BNCC, faremos inicialmente a comparação entre as diretrizes e posteriormente entre os documentos curriculares. Inicialmente é feita uma análise geral dos documentos. A concentração é feita com relação ao Ensino Médio, e, sobretudo nos PCN e BNCC, a Área de Ciências da Natureza, depois a disciplina de Física. Os trechos recortados dos documentos não são apresentados na ordem do original, mas de acordo com o que entendemos revelar de maneira mais clara as intenções do texto.

O objetivo é o de tentar verificar em que medida se expressam convergências ou divergências de sentidos atribuídos, e de importância dada ao conceito de competência nos diferentes âmbitos do sistema de ensino brasileiro por meio dos documentos analisados.

\subsection{A Lei de Diretrizes e Bases (LDB/96)}

\subsubsection{LDB/96: histórico e estrutura do documento}

Com base nos princípios estabelecidos pela constituição federal de 1988, o então Presidente da República, Fernando Henrique Cardoso sancionou em 1996 a Lei de Diretrizes e Bases da Educação Brasileira (LDB/96). Esta lei define e estabelece os princípios, direitos básicos, organização e outros elementos relacionados ao sistema brasileiro de educação.

A LDB/96 possui 92 artigos divididos em 9 títulos. O Título I - Da educação, apresenta o conceito de educação; o Título II - Dos Princípios e Fins da Educação Nacional, apresenta os princípios a partir dos quais a educação será estruturada; o Título III - Do Direito à Educação e do Dever de Educar, define o direito de acesso do cidadão a uma educação gratuita desde o ensino 
infantil até que se conclua o que atualmente se chama de ensino médio. Atribui também ao estado, o dever de garantir tal acesso. O Título IV - Da Organização da Educação Nacional, estabelece os níveis de governo responsáveis por cada etapa de ensino, sendo os municípios responsáveis por gerenciar a oferta de educação infantil e fundamental, os estados responsáveis por gerir a educação de segundo grau, ou ensino médio e a união responsável por gerir todo o sistema dando-Ihe unidade e integração. O Título V - Dos Níveis e das Modalidades de Educação e Ensino, estabelece os limites e características gerais de cada nível de ensino, básico, superior e profissional. $O$ Título VI - Dos Profissionais da Educação, apresenta as características, formação e atuação dos profissionais da educação; o Título VII - Dos Recursos financeiros, estabelece como será feita distribuição e destinação de recursos da união e dos estados para suprir às necessidades das redes de educação. $O$ Título VIII - Das Disposições Gerais, apresenta diversas situações especiais para a oferta de educação, como a oferta de educação bilíngue para comunidades indígenas. E por fim, o Título IX - trata a respeito da transição do sistema anterior para o sistema que obedece à nova lei, estabelecendo prazos e metas para as adaptações.

Há mais de 20 anos a LDB/96 tem sido base para a elaboração e implementação de currículos, políticas públicas e programas de educação. A seguir, será feito um breve levantamento sobre a presença das competências nesse documento.

\subsubsection{As competências na LDB/96}

O documento trata da estrutura, dos direitos e deveres relacionados ao sistema educacional brasileiro. Esse tratamento é feito de maneira bastante geral, portanto em alguns momentos se refere aos governos estaduais e municipais, em outras às unidades de ensino ou aos alunos e alunas que serão atendidos por este sistema. Dessa forma, o termo "competência" assume significados diversos e aparece, referindo-se a diferentes âmbitos e atores envolvidos nesse sistema.

O termo "competência" aparece 9 vezes no documento. Em 5 ocorrências, o sentido não é educacional, mas jurídico, e diz respeito ao 
estabelecimento de jurisdições e autoridades a atores e órgãos específicos. Em 2 delas, o sentido é de capacidade técnica de realizar determinada ação. As outras duas ocorrências estão de alguma forma relacionadas às competências educacionais, tal como tratadas no capítulo 2 como em "O processo [...] considerará as competências e as habilidades definidas na Base Nacional Comum Curricular'. (BRASIL, Art. $\left.3^{\circ}, 1996\right)^{19}$.

Como pudemos verificar no capítulo 2, mesmo em educação, o termo "competência" pode assumir sentidos múltiplos. Além disso, diversos outros termos e conceitos estão relacionados de maneira direta ou indireta às competências. Destacamos aqui as ideias de: Autonomia, Interdisciplinaridade e Contextualização, que, de acordo com o exposto no capítulo 2, entendemos serem elementos de grande importância para a estruturação de competências educacionais.

O termo autonomia apresenta também 8 ocorrências no documento e em apenas uma delas, refere-se ao desenvolvimento de autonomia por parte do estudante.

Art. 35. O ensino médio, etapa final da educação básica, com duração mínima de três anos, terá como finalidades:

III - o aprimoramento do educando como pessoa humana, incluindo a formação ética e o desenvolvimento da autonomia intelectual e do pensamento crítico;

(BRASIL, 1996).

O termo Interdisciplinaridade e Contextualização não foram encontrados no documento.

$\mathrm{Na}$ próxima seção, apresentaremos as Diretrizes Curriculares, documento que, com base na LDB/96, apresenta as orientações mais específicas de objetivos e organização da educação brasileira.

\subsection{As Diretrizes Curriculares Nacionais (DCN)}

\subsubsection{DCN: Histórico e estrutura dos documentos}

19 A versão consultada já apresenta os incisos mais recentes, este artigo, por exemplo, foi incluído no ano de 2017. 
$\mathrm{Na}$ segunda metade da década de 1990, foi experimentada grande reestruturação no sistema educacional brasileiro. Como visto anteriormente a LDB/96 estabelece princípios gerais para a educação, com base na constituinte de 1988. Essa Lei substitui a anterior, vigente desde a década de 1960.

Sendo a LDB/96 um documento que trata de maneira geral dos temas relativos à educação, foi necessária a elaboração de documentos complementares para especificar e orientar a implantação dos princípios ali encontrados. É nesse contexto de novidades políticas, econômicas e sociais que, em 1998, são apresentadas as Diretrizes Curriculares Nacionais (DCN1998) (MOEHLECKE, 2012). Essas diretrizes vigoram como orientações para a educação por mais de 10 anos, quando em 2012, são apresentadas novas diretrizes (DCN-2012) em virtude das mudanças ocorridas na sociedade brasileira e mundial nos âmbitos político, econômico e social. Duas mudanças marcantes apontadas por Moehlecke (2012), entre os documentos de 1998 e 2012, são uma maior atenção à diversidade cultural e econômica, e às particularidades das diferentes regiões e comunidades brasileiras. A autora afirma que

Para além das desigualdades sociais que antes diferenciavam o currículo no ensino médio entre aqueles que teriam de postergar o ingresso no mercado de trabalho e aqueles que já estavam nele inseridos, as novas diretrizes trazem ao debate as múltiplas identidades desses jovens e suas distintas realidades sociais, culturais, etárias etc. (MOEHLECKE, 2012).

Essa tentativa de considerar as multiplicidades de modo a integrar as comunidades deu base para uma concepção de currículo de "base unitária e com parte diversificada" (MOEHLECKE, 2012), que dará suporte para a elaboração da Base Nacional Comum Curricular (BNCC) da qual trataremos na seção seguinte.

As Diretrizes orientam e direcionam os currículos em diferentes níveis e contextos de ensino. Neste trabalho nos concentraremos nas resoluções de ambos os documentos, que dizem respeito às orientações para o Ensino Médio. Sem considerar as especificidades de Ensino Médio Profissional, Educação Especial, Educação Para Jovens e Adultos etc. 
Com base na análise das resoluções, observamos diferenças importantes na estrutura dos documentos das Diretrizes Curriculares quando se comparam as versões de 1998 e 2012. Na última versão, são apresentados subtítulos que organizam os assuntos do que tratam o documento. Na versão 1998 essa especificidade não é tão clara.

O quadro a seguir apresenta a organização explicita geral dos artigos dentro dos títulos e subtítulos (capítulos), das DCN-2012.

\begin{tabular}{|c|c|c|}
\hline \multicolumn{3}{|c|}{ Quadro 4.1 - Estrutura Geral da DCN-2012 } \\
\hline \multirow{2}{*}{$\begin{array}{l}\text { Título I - Objeto e } \\
\text { referência. }\end{array}$} & Capítulo I - Objeto. & Artigos 1-2. \\
\hline & Capítulo II - Referencial legal e conceitual. & Artigos 3-6. \\
\hline \multirow{2}{*}{$\begin{array}{l}\text { Título II - Organização } \\
\text { curricular e formas de } \\
\text { oferta. }\end{array}$} & Capítulo I - Organização currícular. & Artigos 7-13. \\
\hline & $\begin{array}{l}\text { Capítulo II - Formas de oferta e } \\
\text { organização. }\end{array}$ & Artigo 14. \\
\hline \multirow{2}{*}{$\begin{array}{l}\text { Título III - Do projeto } \\
\text { político-pedagógico e dos } \\
\text { sistemas de ensino. }\end{array}$} & Capítulo I - Do projeto político-pedagógico. & Artigos $15-16$ \\
\hline & Capítulo II - Dos sistemas de ensino. & Artigos 17-23. \\
\hline
\end{tabular}

Fonte: Títulos e subtítulos da Diretrizes Curriculares Nacionais (DCN-2012).

Os artigos 1 e 2 definem o âmbito no qual se aplicam as diretrizes que são "todas as formas e modalidades de Ensino Médio" (BRASIL, 2012). Os artigos 3 a 6 definem o referencial teórico que apoia o desenvolvimento das diretrizes, sendo a Lei de Diretrizes e Bases (LDB/96) o principal documento citado. Alguns conceitos importantes tais como; trabalho, ciência, tecnologia, cultura e currículo são conceituados para que se defina aquilo à que 0 documento se refere quando faz uso dos termos. Os artigos 7 a 13 determinam a organização do currículo, definindo as áreas de conhecimento nas quais 0 currículo deve se organizar e as componentes curriculares (disciplinas) obrigatórias. O artigo 14 define como deve ser o oferecimento do ensino, determinando carga horária mínima, períodos de atendimento e parâmetros para a Educação de Jovens e Adultos e para a Educação Especial. Os artigos 
15 e 16 determinam o que o projeto escolar deve conter e considerar, determinando também as orientações que deve fornecer com relação à organização e adequação do trabalho escolar. Por fim, os artigos 17 a 23 tratam da atuação dos sistemas de ensino com vistas à implementação das diretrizes do documento.

Organizar o texto do DCN-1998 na estrutura do DCN-2012 como apresentado anteriormente, mostrou-se uma abordagem complexa, pois, embora os documentos apresentem temas gerais comuns, a estrutura, organização e abordagem são distintas. Por isso será apresentada a seguir uma tentativa de estruturação geral do DCN-1998, a partir de títulos definidos neste trabalho.

Quadro 4.2 - Nossa visão da organização das Diretrizes Curriculares Nacionais (DCN-1998).

I - Objeto

Artigo 1.

II - Finalidade.

Artigo 2.

III - Organização currícular.

Artigos 3-10.

IV - Oferecimento.

Artigo 11-14.

Fonte: Elaborado pelo autor.

A despeito de uma estrutura geral para cada um dos documentos, entendemos que alguns temas importantes para os objetivos deste trabalho estão presentes em ambos. Dedicaremos um olhar mais atento agora aos conceitos de currículo e competência

As duas resoluções estabelecem a Lei 9.394/96 ou Lei de Diretrizes de Bases (LDB/96) como princípio norteador para a estruturação de seus projetos político-pedagógicos, contudo os dois documentos apresentam diferentes entendimentos da Lei em questão, ou pelo menos dos valores que se considera importantes para a estruturação de um projeto escolar.

art. $2^{\circ}$ - A organização curricular de cada escola será orientada pelos valores apresentados na Lei ㅇ 9.394/96, a saber: 
I- os fundamentais ao interesse social, aos direitos e aos deveres dos cidadãos, de respeito ao bem comum e à ordem democrática;

II- os que fortaleçam os vínculos de família, os laços de solidariedade humana e de tolerância recíproca.

(BRASIL - DCNEM, 1998, p. 1)

Art. $4^{\circ}$ As unidades escolares que ministram esta etapa da Educação Básica devem estruturar seus projetos político-pedagógicos considerando as finalidades previstas na Lei no 9.394/96 (Lei de Diretrizes e Bases da Educação Nacional):

I - a consolidação e o aprofundamento dos conhecimentos adquiridos no Ensino Fundamental, possibilitando o prosseguimento de estudos;

II - a preparação básica para o trabalho e a cidadania do educando para continuar aprendendo, de modo a ser capaz de se adaptar a novas condições de ocupação ou aperfeiçoamento posteriores;

III - o aprimoramento do educando como pessoa humana, incluindo a formação ética e o desenvolvimento da autonomia intelectual e do pensamento crítico;

IV - a compreensão dos fundamentos científico-tecnológicos dos processos produtivos, relacionando a teoria com a prática.

(BRASIL - DCNEM, 2012, p. 1)

Observa-se não apenas uma mudança quantitativa nos valores que se depreende a partir da LDB/96, pois a DCN-2012 apresenta mais artigos do que a DCN-1998, mas uma transformação no sentido do que se entende por valores. $\mathrm{Na} \mathrm{DCN}-1998$, os valores citados mostram proeminência das instituições sociais e da adequação do indivíduo a estas instituições em funcionamento. A cidadania, a ordem democrática e a família devem receber indivíduos alinhados e aliados à manutenção de seu funcionamento. Por outro lado, os valores apresentados no texto na DNC-2012 mostram um foco maior na pessoa e na sua formação. Como o ensino médio deve desenvolver a formação iniciada no ensino fundamental e a relação do indivíduo com o conhecimento adquirido. Além da preparação básica para o trabalho e cidadania do educando, mas essa preparação com fim de que este educando seja capaz de "continuar aprendendo" e que seja capaz de se adaptar à diferentes contextos e desafios. Diante de um mundo em constante mudança, 
sobretudo por conta de um desenvolvimento científico-tecnológico cada vez mais acelerado, embora não totalmente inovador, é também evidenciado como valor a compreensão desses processos por parte do indivíduo e de como estes impactam em seu dia-a-dia. O desenvolvimento humano também é lembrado, valorizando-se um indivíduo ético e com pensamento crítico.

A partir do artigo $10^{\circ}$ se começa a tratar especificamente da organização curricular de uma Base Nacional Comum. $O$ artigo diz que 0 currículo deve ser organizado em áreas de conhecimento que são: iLinguagens, Códigos e suas Tecnologias, ii- Ciências da Natureza, Matemática e suas Tecnologias, iii- Ciências Humanas e suas Tecnologias.

Por sua vez o DCN-2012 apresenta a organização curricular a partir do artigo $7^{\circ}$ estabelecendo uma Base Nacional Comum, mas também uma parte do currículo que considera as características regionais do local em que a escola está inserida. No artigo $8^{\circ}$ são introduzidas as áreas de conhecimentos nas quais o currículo deve se organizar, a saber: i- Linguagens, ii- Matemática, iii- Ciências da Natureza e iv- Ciências Humanas. Os parágrafos seguintes deste mesmo artigo contemplam os princípios de interdisciplinaridade e contextualização que foram citados em DCN-1998. O princípio da autonomia também é retomado em diversos artigos deste documento, como no artigo $17^{\circ}$ que afirma que os sistemas de ensino devem promover organização institucional que possibilitem "autonomia e protagonismo social dos estudantes" (BRASIL, 2012, p. 200).

Apesar de indicar a organização do currículo em componentes curriculares, a DCN-2012 evidencia que não se "dilui nem exclui componentes curriculares" (BRASIL, 2012), ou seja, disciplinas. Essa indicação não é feita em DCN-1998, o que pode causar mal-entendidos a respeito dos objetivos do documento. Além disso, as DCN-2012 especificam quais são as componentes curriculares obrigatórias e em qual área de conhecimento devem se inserir.

\subsubsection{Competências nas DCN}

Na DCN-1998 não é apresentada uma definição explícita de currículo. É a partir do artigo $10^{\circ}$ que a Base Nacional Comum dos currículos começa a ser tratada de maneira pontual, mas 0 artigo $6^{\circ}$ apresenta os princípios 
pedagógicos gerais que são: Identidade, diversidade e autonomia, interdisciplinaridade e contextualização. As escolas deverão se basear nesses princípios para a estruturação dos currículos. A partir do artigo $7^{0}$ são então apresentados esses princípios gerais.

$\mathrm{O}$ artigo $7^{\circ}$ trata a respeito da ldentidade, diversidade e autonomia que exige pluralização do currículo, colocando-se a necessidade de observância dos princípios de Identidade, diversidade e autonomia o artigo trata das diversas abordagens curriculares e das diversas relações, articulações e parcerias que as escolas devem observar no desenvolvimento de seus programas.

A respeito da autonomia o parágrafo IV deste artigo afirma que os sistemas de ensino e as escolas "criarão os mecanismos necessários ao fomento e fortalecimento da capacidade de formular e executar propostas pedagógicas escolares características do exercício da autonomia" (BRASIL DCNEM, 1998, p. 104).

O artigo 8 apresenta a necessidade de observância da interdisciplinaridade por parte das escolas, citando a importância de que se desenvolva nos alunos capacidades mais abrangentes tais como: analisar, explicar, prevenir e intervir. O artigo afirma que esses objetivos são alcançados de maneira mais fácil e eficaz se as disciplinas trabalharem integradas umas às outras.

O artigo $9^{0}$ trata da importância da contextualização nas práticas pedagógicas do currículo. Aparecem alguns princípios relacionados a uma aprendizagem significativa e que mostram a importância de que seja possível ao aluno, aplicar na vida cotidiana os conhecimentos adquiridos na escola.

Nas DCN-2012 é apresentada no artigo 6ª definição de currículo

Art. 6으 $\mathrm{O}$ currículo é conceituado como a proposta de ação educativa constituída pela seleção de conhecimentos construídos pela sociedade, expressando-se por práticas escolares que se desdobram em torno de conhecimentos relevantes e pertinentes, permeadas pelas relações sociais, articulando vivências e saberes dos estudantes e contribuindo para o desenvolvimento de suas identidades e condições cognitivas e sócio-afetivas.

(BRASIL, 2012). 
O termo "competência" não aparece na definição de currículo apresentada, e de um ponto de vista mais geral, o termo está quase ausente do documento, sendo apresentado em apenas um trecho, e neste, o sentido se aproxima mais da ideia de capacidade.

O Ensino Médio pode organizar-se em tempos escolares no formato de séries anuais, períodos semestrais, ciclos, módulos, alternância regular de períodos de estudos, grupos não seriados, com base na idade, na competência ${ }^{20}$ e em outros critérios, ou por forma diversa de organização, sempre que 0 interesse do processo de aprendizagem assim o recomendar (BRASIL, 2012, Art. 14º)

No entanto os termos anteriormente destacados: Interdisciplinaridade, autonomia e contexto, são trabalhados ao longo do documento. Também é dada uma maior importância ao impacto social que a educação deve causar por meio os cidadãos por ela formados, pois, de acordo com o Artigo 5ㅇ 0 Ensino Médio baseia-se na "indissociabilidade entre educação e prática social, considerando-se a historicidade dos conhecimentos e dos sujeitos do processo educativo, bem como entre teoria e prática no processo de ensinoaprendizagem" (BRASIL, 2012).

A seguir são apresentados dois artigos em ambos os documentos que entendemos reforçar a estrutura de uma lógica de competências, embora 0 termo não esteja necessariamente presente. Apresentamos contudo, apenas os parágrafos que conforme entendemos, revelam de maneira implícita ou explícita alguma relação com as competências.

$\mathrm{Na}$ DCN-1998 os artigos 4ํ e 5ํe explicitam:

Art. - 4 As propostas pedagógicas das escolas e os currículos constantes dessas propostas incluirão competências básicas, conteúdos e formas de tratamento dos conteúdos previstos pelas finalidades do Ensino Médio estabelecidas pela lei:

I - desenvolvimento da capacidade de aprender e continuar aprendendo, da autonomia intelectual e do pensamento crítico, de modo a ser capaz de prosseguir os estudos e de adaptar-se com flexibilidade a novas condições de ocupação ou de aperfeiçoamento;

\footnotetext{
${ }^{20}$ Destaque deste autor.
} 
II - constituição de significados socialmente construídos e reconhecidos como verdadeiros sobre o mundo físico e natural, sobre a realidade social e política;

III - compreensão do significado das ciências, das letras, das artes e do processo de transformação da sociedade e da cultura, em especial as do Brasil, de modo a possuir as competências e habilidades necessárias ao exercício da cidadania e do trabalho;

V - competência no uso da língua portuguesa, das línguas estrangeiras e outras linguagens contemporâneas como instrumentos de comunicação e como processos de constituição de conhecimento e de exercício de cidadania.

Art. 5o - Para cumprir as finalidades do Ensino Médio previstas pela lei, as escolas organizarão seus currículos de modo a:

I - ter presente que os conteúdos curriculares não são fins em si mesmos, mas meios básicos para constituir competências cognitivas ou sociais, priorizando-as sobre as informações;

II - ter presente que as linguagens são indispensáveis para a constituição de conhecimentos e competências;

III - adotar metodologias de ensino diversificadas, que estimulem a reconstrução do conhecimento e mobilizem o raciocínio, a experimentação, a solução de problemas e outras competências cognitivas superiores;

Em comparação aos artigos também 4ำ e 5ํำ da DCN-2012, em que se apresenta:

Art. 4ำ As unidades escolares que ministram esta etapa da Educação Básica devem estruturar seus projetos político-pedagógicos considerando as finalidades previstas na Lei no 9.394/96 (Lei de Diretrizes e Bases da Educação Nacional):

II - a preparação básica para o trabalho e a cidadania do educando para continuar aprendendo, de modo a ser capaz de se adaptar a novas condições de ocupação ou aperfeiçoamento posterior;

III - o aprimoramento do educando como pessoa humana, incluindo a formação ética e o desenvolvimento da autonomia intelectual e do pensamento crítico;

Art. 5 $\mathrm{O}$ Ensino Médio em todas as suas formas de oferta e organização, baseia-se em: 
V - indissociabilidade entre educação e prática social, considerandose a historicidade dos conhecimentos e dos sujeitos do processo educativo, bem como entre teoria e prática no processo de ensinoaprendizagem;

VI - integração de conhecimentos gerais e, quando for o caso, técnico-profissionais realizada na perspectiva da interdisciplinaridade e da contextualização;

VIII - integração entre educação e as dimensões do trabalho, da ciência, da tecnologia e da cultura como base da proposta e do desenvolvimento curricular.

Embora a noção de competências seja desenvolvida em ambos os documentos, nosso entendimento é de que, aquilo que se evidencia como valor de formação, é muito mais alinhado com elementos do sentido de competência de acordo com o exposto no capítulo 2 em DCN-2012, embora o termo seja ali menos utilizado. Para Perrenoud, por exemplo, um dos sentidos da noção de competência é "uma capacidade de agir eficazmente em um determinado tipo de situação, apoiada em conhecimentos, mas sem limitar-se a eles" (PERRENOUD, 1999). Dessa forma fica evidenciado que a situação importa para a manifestação de uma capacidade do indivíduo. Monica Ribeiro da Silva também indica que "O 'aprender a aprender' constitui-se em um dos princípios pedagógicos vinculados às pedagogias ativas" (SILVA, 2008). A valorização da preparação para o mundo do trabalho também é característica do pensamento de Perrenoud, embora ele tenha se preocupado com as críticas direcionadas à essa preparação. Para ele as competências "podem responder a uma demanda social dirigida para a adaptação ao mercado e às mudanças e também podem fornecer os meios para apreender a realidade e não ficar indefeso nas relações sociais" (PERRENOUD, 1999).

\subsection{Os Parâmetros Curriculares Nacionais (PCN) e a Base Nacional Comum Curricular (BNCC)}

Os documentos curriculares devem aproximar as Diretrizes Curriculares da prática educacional. Esses documentos, obedecendo aos direcionamentos apontados a partir das diretrizes, tratam de maneira mais específica a respeito de áreas de conhecimentos, conhecimentos disciplinares, abordagens pedagógicas, que devem ser desenvolvidas na prática 
educacional. Não é pretensão de tais documentos, nem mesmo uma possibilidade prática, indicar todos os passos que devem ser dados no processo de formação, mas indicam de forma um pouco mais específica os direcionamentos educacionais gerais indicados nas diretrizes. Essa maior especificidade é observada na medida em que enquanto as diretrizes se referem aos sistemas e instituições de ensino de maneira geral, os Parâmetros Curriculares Nacionais (PCN) apresentarão orientações específicas sobre áreas de conhecimento e disciplinas, além de estabelecer objetivos e exemplificar sequências de ensino.

Procuraremos apresentar a estrutura geral dos documentos e a abordagem dada às competências no texto dos PCN e PCN+.

\subsubsection{Histórico e estrutura dos PCN}

Os PCN+ indicam a necessidade de construção do currículo efetivo considerando as característica culturais, sociais e econômicas do local em que se desenvolverá este currículo.

Por sua natureza aberta [os PCN], configuram uma proposta flexível, a ser concretizada nas decisões regionais e locais sobre currículos e sobre programas de transformação da realidade educacional empreendidos pelas autoridades governamentais, pelas escolas e pelos professores. (BRASIL, 1997, p. 13).

Os PCN são apresentados em documentos distintos para cada nível de ensino, e inclusive tiveram publicação em datas distintas. A apresentação inicial é comum para todos os níveis, mas como foi esclarecido anteriormente, o foco deste trabalho será no tratamento dado ao Ensino Médio, referente à Área de Ciências da Natureza. Dessa forma, é importante notar que os PCN estruturam-se em volumes, cada qual relacionado a uma Área de Conhecimento. $\mathrm{O}$ volume destinado às Ciências da Natureza, Matemática e suas Tecnologias, inicia com uma introdução sobre a reformulação do Ensino Médio em relação ao modelo anteriormente adotado, apresentando também uma discussão a respeito das áreas de conhecimento. O texto apresenta também um capítulo sobre a articulação entre a linguagem da matemática e a estrutura do conhecimento científico. Contudo, os capítulos subsequentes mostram uma organização altamente disciplinar. Cada capítulo apresenta como 
título o nome de uma disciplina relacionada à área: Biologia, Física, Química, Matemática. $O$ documento é finalizado com um capítulo sobre a avaliação em um ensino que articula disciplinas em áreas de conhecimento e a necessidade de formação permanente de professores.

Dentro da disciplina de Física, depois de discutida sua importância na formação do estudante, são apresentadas as competências a ela relacionadas e sugeridos temas integradores, a partir dos quais possam ser desenvolvidas essas competências. No que diz respeito à organização do trabalho escolar são feitas sugestões de possíveis estruturas de organização de temas ao longo do ensino médio, em que também é apresentada a preocupação com a integração entre escolas de uma mesma região, de modo que o processo de formação do estudante não seja comprometido em caso de mudança de escola (BRASIL, 2000). O documento apresenta também estratégias de ação e sugestões de abordagem, por meio das quais se possa atingir os objetivos formativos de maneira mais eficaz.

\subsubsection{As competências na área de Ciências da Natureza e} em Física

Nos PCN+, a seção dedicada às Ciências da Natureza e Matemática (CNM), inicia caracterizando a relação da sociedade atual com os conhecimentos relativos às CNM. São destacadas características comuns à Biologia, à Física, à Química e à Matemática no sentido de que se estabeleçam relações entre as diferentes disciplinas, de modo que a área de CNM seja apresentada de forma mais coesa.

Destacam-se três competências centrais que se espera desenvolver em CNM, a saber: Representação e Comunicação, Investigação e Compreensão e Contextualização Sócio-Cultural. As competências de Representação e Comunicação e de Contextualização Sócio-Cultural, são apresentadas como "conectores" entre a área de CNM e as demais áreas de conhecimento da maneira como é apresentado na figura a seguir. 
Figura 4.1 - Relação entre as áreas de conhecimento a partir de Competências Centrais

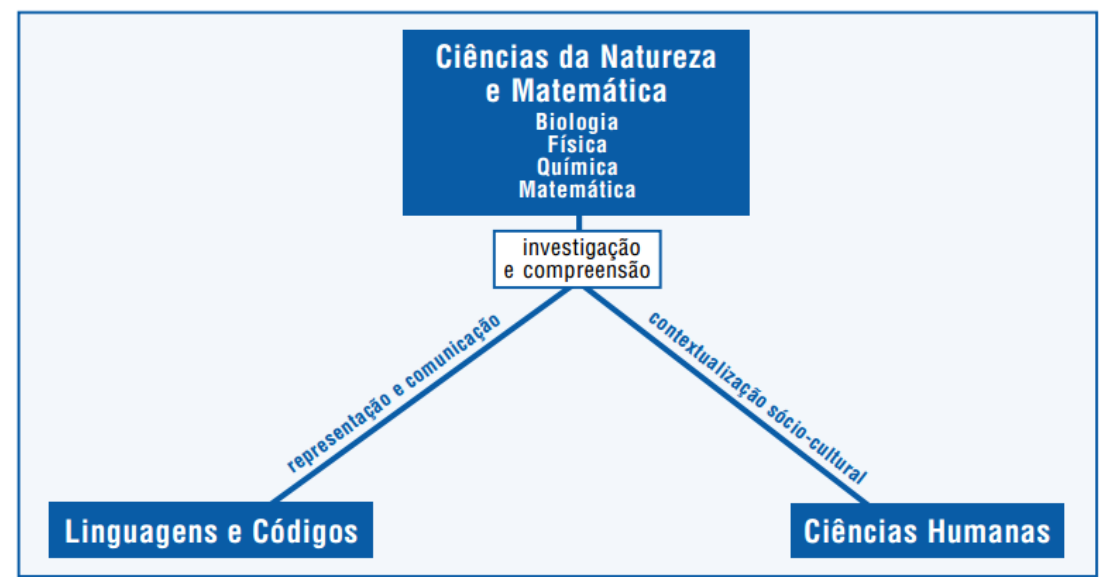

Fonte: Parâmetros Curriculares Nacionais - Área de Ciências da Natureza, Matemática e suas Tecnologias (PCN+) (BRASIL, 2000, p. 25).

Cada competência passa então a ser detalhada. São apresentadas sínteses das competências subordinadas em todas as competências gerais citadas anteriormente. Neste trabalho, as competências subordinadas serão indicadas como Habilidades.

Além de definições a respeito das competências, são apresentados exemplos sobre como trabalhar o desenvolvimento das competências em cada disciplina e de forma integrada. São apresentados alguns assuntos específicos ou temas estruturadores e indicações de como esses temas podem ser tratados envolvendo as disciplinas da área de CNM. Logo após esse desenvolvimento com relação à área de CNM, são apresentados os aspectos específicos de cada disciplina.

Os PCN+ iniciam a seção que trata sobre a disciplina Física explicando sobre a importância desta disciplina na escola e apontando para o objetivo de formação de um "cidadão contemporâneo" (BRASIL, 2000). São apresentadas as características da Física e sua relação com as DCN e os PCN. Finalmente as competências da disciplina aparecem em uma tabela que relaciona as Competências Gerais, anteriormente mencionadas, com as habilidades que indicam ações para o desenvolvimento da competência associada. As habilidades são apresentadas em graus de complexidade cada vez maior, como pode ser verificado a seguir, com a apresentação de um quadro resumido com as competências gerais e as habilidades da área de CNM. 
Quadro 4.3. - Resumo das Competências Gerais e Habilidades Relacionadas à Área de Ciências da Natureza e Matemática

COMPETÊNCIA GERAL

\section{Representação e comunicação}

Investigação e compreensão

\section{HABILIDADE NA ÁREA}

Reconhecer e utilizar adequadamente, na forma oral e escrita, símbolos, códigos e nomenclatura da linguagem científica.

Ler, articular e interpretar símbolos e códigos em diferentes linguagens e Representações: sentenças, equações, esquemas, diagrama, tabelas, gráficos e Representações geométricas.

Consultar, analisar e interpretar textos e comunicações de ciência e tecnologia veiculados por diferentes meios.

Elaborar comunicações orais ou escritas para relatar, analisar e sistematizar eventos, Fenômenos, Experimentos, questões, entrevistas, visitas, correspondências.

Analisar, argumentar e posicionar-se criticamente em relação a temas de ciência e tecnologia.

Identificar em dada situação-problema as informações ou variáveis relevantes e possíveis estratégias para resolvê-la.

Identificar fenômenos naturais ou grandezas em dado domínio do conhecimento científico, estabelecer relações; identificar regularidades, invariantes e transformações.

Selecionar e utilizar instrumentos de medição e de cálculo, representar dados e utilizar escalas, fazer estimativas, elaborar hipóteses e interpretar resultados.

Reconhecer, utilizar, interpretar e propor modelos explicativos para fenômenos ou sistemas naturais ou tecnológicos.

Articular, integrar e sistematizar fenômenos e teorias dentro de uma ciência, entre as várias ciências e áreas de conhecimento. 
Quadro 4.3. - Resumo das Competências Gerais e Habilidades Relacionadas à Área de Ciências da Natureza e Matemática

\begin{tabular}{|l|l|}
\hline COMPETÊNCIA GERAL & HABILIDADE NA ÁREA \\
\hline $\begin{array}{l}\text { Compreender o conhecimento científico o o tecnológico como } \\
\text { resultados de uma construção humana, inseridos em um } \\
\text { processo histórico e social. }\end{array}$ \\
\hline $\begin{array}{l}\text { Compreender a ciência e a tecnologia como partes integrantes } \\
\text { da cultura humana contemporânea. }\end{array}$ \\
\hline Cultural & $\begin{array}{l}\text { Reconhecer e avaliar o desenvolvimento tecnológico } \\
\text { contemporâneo, suas relações com as ciências, seu papel na } \\
\text { vida humana, sua presença no mundo cotidiano e seus impactos } \\
\text { na vida social. }\end{array}$ \\
\hline $\begin{array}{l}\text { Reconhecer e avaliar o caráter ético do conhecimento científico e } \\
\text { tecnológico e utilizar esses conhecimentos no exercício da } \\
\text { cidadania. }\end{array}$
\end{tabular}

Fonte: Parâmetros Curriculares Nacionais - Área de Ciências da Natureza, Matemática e suas Tecnologias (PCN+)

São apresentados então Temas Estruturadores da disciplina, por meio dos quais se deve buscar o desenvolvimento das Competências Gerais apresentadas.

Esses temas apresentam uma das possíveis formas para a organização das atividades escolares, [...]. Não se trata, certamente, da única releitura e organização dos conteúdos de Física em termos dos objetivos desejados, mas serve, sobretudo, para exemplificar, de forma concreta, as possibilidades e os caminhos para o desenvolvimento das competências e habilidades já identificadas. (BRASIL, 2000, p. 71).

No trecho anterior é interessante destacar que os Temas apresentados não são normativos, mas um exemplo do tipo de estrutura que pode ser adotada para o desenvolvimento das competências. Os Temas Estruturadores apresentados são apresentados no quadro abaixo. 
Quadro 4.4. - Temas estruturadores da Área de Conhecimento de Ciências da

Natureza e Matemática nos Parâmetros Curriculares Nacionais

Movimentos: variações e conservações

Calor, ambiente e usos de energia

Som, imagem e informação

Equipamentos elétricos e telecomunicações

Matéria e radiação

Universo, Terra e vida

Fonte: Parâmetros Curriculares Nacionais - Área de Ciências da Natureza, Matemática e suas Tecnologias (PCN+)

Cada Tema Estruturador é então apresentado em Unidades Temáticas, detalhamentos e indicações de abordagens para cada tema. É apresentada então uma seção com indicações a respeito da Organização do Trabalho Escolar, apresentando três possíveis sequências de abordagem para os Temas Estruturadores, considerando cada semestre de cada ano do Ensino Médio. É interessante notar que o texto explicita que as Unidades temáticas não constituem uma "lista de conteúdos mínimos" (BRASIL, 2000), mas em seguida afirma que "... ao final da educação básica, espera-se que todos os jovens tenham tido oportunidade de ter contato com cada um desses temas, embora, provavelmente, em profundidades ou extensões diferentes." (BRASIL, 2000, p. 80).

Por fim são apresentadas Estratégias de Ação, que apresentam sugestões de como se abordar os temas propostos. Discussões a respeito da contextualização com o cotidiano do aluno e a utilização da experimentação como estratégia de ensino são apresentadas. 


\subsubsection{A presença do conceito de competência nos PCN}

Nos PCN e PCN+ o conceito de competência é central para o embasamento teórico e para a estruturação desses documentos.

Os PCN foram desenvolvidos com base nos conceitos de competências e habilidades. Somente no documento dos PCN de Ciências da Natureza e suas Tecnologias são encontradas 229 ocorrências do termo competência, e 42 ocorrências do termo habilidade.

As competências gerais são apresentadas como o objetivo central de aprendizado, uma vez que organiza as disciplinas de modo a traduzir essas competências gerais.

Para se compor um programa de trabalho como o sugerido, inicialmente é preciso explicitar vínculos e aspectos comuns entre as disciplinas da área, assim como mostrar como as Ciências da Natureza e a Matemática traduzem as competências gerais. Isso vai ser esboçado a seguir e, a partir disso, se vai revelar, no conjunto e em cada uma das disciplinas, a maneira pela qual, juntamente com o aprendizado do conhecimento específico, as competências gerais estarão sendo desenvolvidas. Isso será mais concretizado ao se organizar o programa de ensino das disciplinas em temas que estruturam o conhecimento disciplinar e, ao mesmo tempo, são um espaço com ênfases e características próprias de promoção de competências e habilidades. (BRASIL, 2000, p. 24).

A estrutura dada à área de Ciências da Natureza é com base nas competências gerais que se desdobram em competências mais específicas, ou direcionadas para o tipo de ação que se espera desenvolver com os conhecimentos dessa área.

Embora as competências tenham presença importante no documento, e em suas ocorrências o sentido quase sempre relacionado a uma competência do campo educacional, existem diferenças entre as competências discutidas pelos teóricos como apresentado no capítulo 2, e aquelas que são apresentadas nos PCN.

Em primeiro lugar é importante destacar que tanto Perrenoud (1999) quanto, e principalmente, Jonnaert et al. (2010) entendem que existe grande dificuldade em se tratar de competências como um objeto curricular. Se as competências se desenvolvem em situação real, ou que procura simular a 
realidade, como estabelecer a priori as competências que deverão ser desenvolvidas?

Além disso, as competências gerais da área de Ciências da Natureza estão relacionadas com habilidades específicas, mas em situações reais, como determinar se o aluno precisará "elaborar comunicações orais" para resolver situações de Contextualização Sócio-Cultural, pois esta habilidade esta associada à competência de Representação e Comunicação?

No entanto é preciso lembrar que o conceito de competência não possui uma única definição, sobretudo em educação. Para Philippe Perrenoud (1999) "não existe uma definição clara e partilhada das competências." (PERRENOUD, 1999, p. 19). Contudo, é possível delinear algumas características esperadas de um ensino que considera o desenvolvimento das competências.

Espera-se que os alunos continuem mantendo certa relação de aprendizagem e compreensão com novos saberes depois da escola e que sejam capazes de transpor os conhecimentos apreendidos em novos contextos, diante de novas situações. [...]

Uma formação por competências exige não apenas a atualização dos conteúdos, mas também novas práticas educacionais. (RICARDO, CUSTÓDIO, REZENDE, 2008, p. 2401-2).

Nesse sentido, resgatamos aqui os termos Autonomia, Interdisciplinaridade e Contextualização por serem parte importante daquilo que constitui o conceito de competência, e que de fato são trabalhados constantemente ao longo dos PCN. A autonomia do estudante para aprender e continuar aprendendo, articulando conhecimentos para desenvolver ações interdisciplinares dentro de um contexto específico, são elementos que podem ser identificados no trecho:

De forma especial, os projetos, que podem ser propostos no interior de cada disciplina e também articulando disciplinas da área ou entre áreas, são instrumentos didáticos inestimáveis para promover autonomia e experiência coletiva no trabalho de equipe, qualificações e competências essenciais para a vida. (BRASIL, 2010, p. 135).

Portanto, embora a transposição deste conceito dos teóricos para a constituição de um documento curricular provoque algumas diferenças no 
sentido atribuído às competências para que haja acomodação ao novo contexto, elementos essenciais ainda podem ser observados no que orienta as ações educacionais para novos modelos em relação ao entendimento geral do que caracteriza um ensino tradicional. A orientação de trabalho por projetos, desenvolvimento de autonomia dos estudantes e incentivo à interdisciplinaridade, são elementos que apontam para isso.

\subsubsection{Histórico, estrutura e competências na BNCC}

Não é a intenção deste trabalho apresentar uma análise detalhada da BNCC, sobretudo porque o texto que se refere ao ensino médio, foco deste trabalho, não é definitivo. Serão apresentados apenas comentários gerais, especialmente sobre o que se refere às competências.

Atualmente, a Base Nacional Comum Curricular (BNCC) está no centro do debate a respeito de estabelecimento de um documento curricular brasileiro. Os PCN e PCN+ foram estruturados em função das DCN-1998. Apesar de a necessidade de uma base curricular nacional e sua característica geral ser apresentada na LDB/96 (BRASIL, 1996) ${ }^{21}$ e discutida no documento de diretrizes curriculares anterior, as DCN-2012 apresentam com bastante ênfase e delineando as características de tal base.

Nesta publicação, estão reunidas as novas Diretrizes Curriculares Nacionais para a Educação Básica. São estas diretrizes que estabelecem a base nacional comum, responsável por orientar a organização, articulação, o desenvolvimento e a avaliação das propostas pedagógicas de todas as redes de ensino brasileiras (BRASIL, 2012, p. 5)

A publicação da BNCC tem sido causa de intenso debate entre os mais variados setores, dentro e fora da área de educação. Desde o início do deste trabalho em 2015, foram publicadas três versões preliminares para a BNCC, sendo que no final do ano de 2017 foi homologada a versão final apenas para o ensino infantil e fundamental. O texto dedicado ao Ensino Médio não é definitivo e teve sua última versão divulgada em Abril de 2018.

${ }^{21}$ Art. 26. Os currículos do Ensino Fundamental e Médio devem ter uma base nacional comum, a ser complementada, em cada sistema de ensino e estabelecimento escolar, por uma parte diversificada, exigida pelas características regionais e locais da sociedade, da cultura, da economia e da clientela. (BRASIL, 1996). 
Um dos diversos pontos de discussão com relação ao texto da BNCC é exatamente a maneira como se encaram as competências. No texto preliminar para a BNCC, divulgado em 2015, de maneira muito parecida com o que acontece com a DCN-2012, não foi utilizado o termo "competência", embora, nosso entendimento é o de que, a despeito do uso do termo, o conceito, em essência, está presente.

$\mathrm{Na}$ versão de 2018, é possível verificar que o termo "competência" é amplamente utilizado, sendo inclusive um importante estruturador do documento.

$\mathrm{Na}$ BNCC, competência é definida como a mobilização de conhecimentos (conceitos e procedimentos), habilidades (práticas, cognitivas e socioemocionais), atitudes e valores para resolver demandas complexas da vida cotidiana, do pleno exercício da cidadania e do mundo do trabalho (BRASIL, 2018, p. 8).

A definição de competência apresentada pela BNCC é interessante por destacar, além de conhecimentos e recursos cognitivos, outras dimensões do que precisa ser mobilizado, como atitudes e valores, para apresentar respostas às demandas da vida.

As competências gerais apresentadas, não referem-se a apenas uma área de conhecimento, mas estruturam e articulam-se "no tratamento didático proposto para as três etapas da Educação Básica (Educação Infantil, Ensino Fundamental e Ensino Médio), articulando-se na construção de conhecimentos, no desenvolvimento de habilidades e na formação de atitudes e valores, nos termos da LDB" (BRASIL, 2018). A seguir são apresentadas, de maneira resumida, essas competências gerais.

\section{Quadro 4.5 - Competências Gerais da Educação}

1. Valorizar e utilizar os conhecimentos historicamente construídos sobre o mundo.

2. Exercitar a curiosidade intelectual e recorrer à abordagem própria das ciências.

3. Valorizar e fruir as diversas manifestações artísticas e culturais.

4. Utilizar diferentes linguagens - verbal (oral ou visual-motora, como Libras, e escrita), corporal, visual, sonora e digital -, bem como conhecimentos das linguagens artística, matemática e científica, para se expressar e partilhar informações. 


\section{Quadro 4.5 - Competências Gerais da Educação}

5. Compreender, utilizar e criar tecnologias digitais de informação e comunicação de forma crítica, significativa, reflexiva e ética nas diversas práticas sociais.

6. Valorizar a diversidade de saberes e vivências culturais.

7. Argumentar com base em fatos, dados e informações confiáveis, para formular, negociar e defender ideias.

8. Conhecer-se, apreciar-se e cuidar de sua saúde física e emocional.

9. Exercitar a empatia, o diálogo, a resolução de conflitos e a cooperação, fazendo-se respeitar e promovendo o respeito ao outro e aos direitos humanos.

10. Agir pessoal e coletivamente com autonomia, responsabilidade, flexibilidade, resiliência e determinação, tomando decisões com base em princípios éticos, democráticos, inclusivos, sustentáveis e solidários.

Fonte: Base Nacional Comum Curricular (BNCC) (Brasil, 2018, p. 9).

O documento apresenta então os marcos legais que the dão suporte, tais como a LDB/96, a DCN-2012 e o Plano Nacional de Educação (PNE), publicado em 2014 e que apresenta metas para a educação brasileira a serem atingidas até o ano de 2024.

Mas é nos Fundamentos Pedagógicos da BNCC que fica explícito o "Foco no desenvolvimento de Competências" (BRASIL, 2018). A BNCC, baseada também no posicionamento de organizações internacionais como a Organização para a Cooperação e Desenvolvimento Econômico (OCDE) e a Organização das Nações Unidas para a Educação, a Ciência e Cultura (UNESCO, na sigla em inglês), é justificado o enfoque no desenvolvimento de competências para que se possa preparar os estudantes para resolver "demandas complexas da vida cotidiana" (BRASIL, 2018).

Em seguida é apresentada a estrutura da BNCC considerando todas as etapas de ensino, desde o Ensino Infantil até o final do Ensino Médio, apresentando o quadro geral que a BNCC organiza.

O Ensino Médio é então abordado, primeiramente caracterizando essa etapa de ensino, apresentando como será sua estrutura e como se organizarão as áreas de conhecimento que fazem parte desta etapa educacional. 
São então detalhadas as áreas de: Linguagens e suas Tecnologias, Matemática e suas Tecnologias, Área de Ciências da Natureza e suas Tecnologias e Área de Ciências Humanas e Sociais Aplicadas.

Uma diferença importante é que a divisão por disciplinas não aparece nesta versão da BNCC. Diferente das versões anteriores que apresentavam as Áreas de Conhecimento, mas em seguida desmembravam essas áreas em disciplinas relacionadas, esta desenvolve temas relacionados às Áreas de Conhecimento como um todo, não especificando disciplinas.

Assim, para além dos compromissos firmados no Ensino Fundamental, a BNCC da área de Ciências da Natureza e suas Tecnologias propõe um aprofundamento conceitual nas temáticas Matéria e Energia, Vida e Evolução e Terra e Universo. Elas são consideradas essenciais para que competências cognitivas, comunicativas, pessoais e sociais possam continuar a ser desenvolvidas e mobilizadas na resolução de problemas e tomada de decisões. (BRASIL, 2018, p. 538)

Para cada área de conhecimento são então apresentadas competências habilidades específicas. A seguir é apresentado um quadro com as competências específicas para a Área de Ciências da Natureza e suas Tecnologias.

\section{Quadro 4.6. - Competências Específicas de Ciências da Natureza e Suas Tecnologias para o Ensino}

1. Analisar fenômenos naturais e processos tecnológicos, com base nas relações entre matéria e energia, para propor ações individuais e coletivas que aperfeiçoem processos produtivos, minimizem impactos socioambientais e melhorem as condições de vida em âmbito local, regional e/ou global.

2. Construir e utilizar interpretações sobre a dinâmica da Vida, da Terra e do Cosmos para elaborar argumentos, realizar previsões sobre o funcionamento e a evolução dos seres vivos e do Universo, e fundamentar decisões éticas e responsáveis.

3. Analisar situações-problema e avaliar aplicações do conhecimento científico e tecnológico e suas implicações no mundo, utilizando procedimentos e linguagens próprios das Ciências da Natureza, para propor soluções que considerem demandas locais, regionais e/ou globais, e comunicar suas descobertas e conclusões a públicos variados, em diversos contextos e por meio de diferentes mídias e tecnologias digitais de informação e comunicação (TDIC).

Fonte: Base Nacional Comum Curricular (BNCC), (Brasil, 2018). 
Fica, portanto evidente que, as competências assumem lugar central nesta última versão da BNCC. Destacamos aqui não só o uso do termo de maneira explícita e sua importância como eixo estruturador do documento, mas também a importância dada aos conceitos anteriormente mencionados como fazendo parte da arquitetura de uma competência. A Autonomia, a Interdisciplinaridade e a Contextualização estão presentes na própria definição de competência apresentada pela BNCC. Acreditamos que destacou-se a questão da interdisciplinaridade, uma vez que a divisão de orientações por disciplinas foi suprimida.

As competências são, portanto tema de discussão importante e atual, uma vez que a proposta da BNCC tem esse conceito como central em sua estruturação. Destacamos, contudo que essa versão é ainda preliminar e, portanto pode sofrer alterações consideráveis. 


\section{COMPETÊNCIAS NO NÍVEL DE ORIENTAÇÃO DIDÁTICA}

Em mais um movimento vertical, este capítulo investiga a presença e os sentidos das competências no Nível da Orientação Didática. Ou seja, procuraremos perceber os sentidos atribuídos às competências em um nível do sistema de educação que recebe as orientações dos documentos oficiais. Incluímos aqui a investigação das competências no ENEM, nos editais do Programa Nacional do Livro Didático (PNLD) e nos manuais do professor de dois livros didáticos.

A orientação por parte dos livros didáticos é explicita e torna-se ainda mais evidente na consideração do manual do professor, que fala ao professor, orientando e em alguns casos, dirigindo, a ação docente.

O ENEM por sua vez, não possui o objetivo explícito de orientar o desenvolvimento do ensino, no entanto, diversos cursos são moldados para atender às exigências do exame, e seus itens, por vezes, figuram em seções especiais dos livros didáticos.

Entendemos que o Nível de Orientação Didática possui uma influência mais direta sobre o processo de ensino, pois, sendo mais acessível e possuindo orientações mais práticas e claras, pode ser mais consultado pelos docentes. 
Inicialmente será analisada, a presença das competências no PNLD e em como esse conceito é absorvido pelo manual do professor de duas obras aprovadas por este programa. E depois, com objetivo de realizar uma comparação horizontal, o ENEM é apresentado considerando duas dimensões. Por um lado, sua fundamentação teórica, por outro, sua aplicabilidade, isto é, como as competências se revelam na aplicação desse exame.

\subsection{O Programa Nacional do Livro Didático (PNLD)}

No processo de ensino-aprendizagem um dos elementos presentes é o material didático com base no qual o aluno seguirá o curso ou uma atividade específica. $O$ material didático é em geral e idealmente selecionado pelo professor.

A definição de material didático é bastante ampla, pois "esses materiais são classificados como recursos visuais, auditivos ou audiovisuais, ou seja, recursos que podem estimular o estudante por meio da percepção visual, auditiva ou ambas, simultaneamente" (BRASIL, 2007, p. 22).

Das diversas possibilidades de materiais didáticos, neste capítulo será dada atenção especialmente aos livros didáticos ou livros-texto, mais especificamente ao manual da obra, que direcionado aos professores, revela a concepção pedagógica do autor ou autores. Neste trabalho interessa analisar especificamente a maneira como o conceito de competência está presente (ou não) nas obras em questão.

No Brasil, o Programa Nacional do Livro Didático (PNLD) seleciona obras que farão parte de uma lista enviada às escolas públicas em território nacional. De acordo com o website do Fundo Nacional de Desenvolvimento da Educação (FNDE), os programas de seleção e distribuição de livros didáticos iniciaram em 1937 com a criação do Instituto Nacional do Livro, mas é em 1985 que esse processo passa a ser executado pelo PNLD (FNDE). Os professores de cada escola devem selecionar, a partir da lista disponibilizada, a obra que desejam adotar. Uma vez selecionada, exemplares da obra serão enviados para a escola, que fará a distribuição para os alunos e alunas.

Em 2017, o Ministério da Educação (MEC) investiu mais de $R \$ 1,2$ bilhão para distribuir cerca de 150 milhões de exemplares para 117.690 
escolas. Se os livros distribuídos de fato chegaram aos estudantes, foram quase 30 milhões de beneficiados (FNDE).

Para 2019, em atendimento ao edital de convocação 01/2017, foi aprovada uma lista com 97 coleções, das quais 12 são referentes à componente curricular de Física (FNDE).

Em primeiro lugar será feita uma breve caracterização do edital do PNLD de 2016, ao qual as obras aqui analisadas estão submetidas, e do edital de $2019^{22}$, que possui lista publicada. Fizemos uma busca por menções às competências que dessem direcionamento para a elaboração das obras. Depois disso foram analisados os manuais do professor em duas obras aprovadas para a lista do PNLD. As coleções aqui analisadas foram Física em Contexto cujo principal autor é Maurício Pietrocola e Física para o Ensino Médio de Kazuhito Yamamoto e Luiz Felipe Fuke. Essas obras foram escolhidas, pois, de acordo com nosso entendimento, expressam diferentes visões de competências, embora estejam sujeitas ao mesmo edital, o que deve permitir, de maneira mais rica, uma caracterização e comparação das obras.

\subsubsection{Os editais do PNLD}

Até 2017, ano de publicação do último edital do PNLD, os editais possuíam um ciclo de renovação de três anos, isto é, a cada três anos era realizada nova convocação para a qual as editoras deveriam inscrever seus títulos e uma nova lista de livros autorizados era apresentada aos professores e professoras da rede. A partir de 2019 , no entanto o ciclo de renovação será de 4 anos (MEC).

Os manuais de professor dos livros analisados atendem ao edital 2016, mas pudemos verificar também o manual do professor do título Física para o Ensino Médio, de acordo com a versão que consta na lista do edital de 2019. Não pudemos verificar nenhuma mudança entre as versões, embora o edital 2019 apresente algumas alterações consideráveis em relação ao anterior. Embora a análise comparativa possa ser ampliada, neste trabalho nos concentramos em como o conceito de competência aparece nos editais e nas

\footnotetext{
22 O edital para o PNLD 2019, foi publicado em 2017 e o edital para o PNLD 2016 foi publicado em 2014. Dessa forma o título do edital indica o ano a partir do qual a lista de livros por ele selecionada estará em vigor, mas a referência indicará o ano de sua publicação.
} 
orientações que são apresentadas sobre como este conceito deve aparecer nas obras inscritas no programa.

No edital de 2016, o termo "competência" tem 10 ocorrências, das quais, ao menos 7 vezes é utilizado no sentido de competência para o ensino ou desenvolvimento de competências nos alunos como discutimos no capítulo 2.

Com relação aos critérios eliminatórios, a matemática é destacada como componente que possui critérios específicos, além daqueles comuns a todos os componente curriculares. De acordo com o edital o livro de matemática é adequado na medida em que "favorece a aquisição, pelo aluno, de um saber matemático autônomo e significativo" (PNLD, 2014, p. 10). Destaca-se na frase anterior o uso do termo autonomia, palavra importante para a elaboração do conceito de competência e que foi abordada nesse contexto no capítulo 2.

Ainda sobre os requisitos para o livro de matemática considerado adequado, o edital afirma que o livro não deve

"[...] privilegiar apenas uma, entre as habilidades e competências que deve mobilizar e desenvolver, visto que raciocínio, cálculo mental, interpretação e expressão em matemática envolvem necessariamente várias delas" (PNLD, 2014, p. 10).

Nas outras ocorrências do termo "competências" o edital indica que seu desenvolvimento deve ser estimulado em todas as componentes curriculares.

Com relação ao item "Manual do professor" o edital indica que este deve "[explicitar] a interdisciplinaridade e a contextualização de forma clara" (PNLD, 2014, p. 10). Destacam-se também aqui os termos "interdisciplinar" e "contextualização", novamente, ideias discutidas no capítulo 2 quanto à arquitetura de uma competência.

O edital 2019 do PNLD por sua vez apresenta o termo "competência" 16 vezes, das quais 15 possuem os sentidos das competências de ensino como discutidas no capítulo 2. O conceito de competência no ensino adquire neste edital um caráter de maior importância. É explicitado, por exemplo, que "serão excluídas as obras que não contribuírem para o desenvolvimento das competências gerais e das competências específicas das áreas de conhecimento" (PNLD, 2017, p. 37). As competências a que se refere o edital e 
que os manuais didáticos devem se preocupar em desenvolver, são aquelas que constam na BNCC, apresentada no Anexo III do edital. É importante observar que o edital para o PNLD 2019 foi publicado no final de Julho de 2017, e a BNCC homologada apenas em Dezembro de 2017. Esse fato é reconhecido no próprio edital, que coloca como referência a versão da BNCC não homologada e divulgada em Abril de 2017 (PNLD, 2017).

Com relação aos termos relacionados à arquitetura de uma competência, o edital novamente indica que a coleção deve "explicitar a interdisciplinaridade e a contextualização de forma clara" (PNLD, 2017, p. 38). As obras também devem "contribuir para o desenvolvimento da autonomia de pensamento" (PNLD, 2017, p. 33).

Com relação ao manual do professor, o edital do PNLD 2019 indica que este:

deve apoiá-lo no planejamento e desenvolvimento dos projetos junto aos alunos, explicitando as habilidades e competências a serem desenvolvidas pelos alunos ao longo e ao final de cada projeto. $O$ manual do professor deve ser voltado para professores que trabalham habitualmente com aprendizagem baseada em projetos, mas também para aqueles que nunca trabalharam com essa metodologia. (PNLD, 2017, p. 42).

Dessa forma é interessante notar como, de acordo com os editais do PNLD, os livros didáticos devem trabalhar segundo a perspectiva de se desenvolver a competência dos estudantes, por meio inclusive da orientação de professores e professoras nesse sentido. Termos importantes para a arquitetura de competências, tais como: autonomia, interdisciplinaridade e contexto, são retomados nos editais.

No capítulo 2 discutimos a multiplicidade de sentidos que podem ser atribuídos ao conceito de competência, essa multiplicidade é também aplicada aos conceitos relacionados ao desenvolvimento de competências. Dessa forma, a simples utilização de palavras como autonomia ou interdisciplinaridade não necessariamente indica uma abordagem por competência nos sentidos indicados pelos autores apresentados no capítulo 2. Um exemplo disso é o termo "autonomia", que de acordo com os editais do PNLD, está muito mais relacionada a uma autonomia cognitiva. Tal concepção permite aos estudantes 
solucionar certa classe de problemas, e não necessariamente a uma autonomia de ação, que permite ao cidadão em formação, lançando mão de diversos recursos, inclusive os cognitivos, uma ação real diante de uma situação real. Essa diferença será discutida de forma mais aprofundada no capítulo 6 a respeito das visões dos professores em relação às competências.

\subsubsection{Comparando manuais do professor nos livros didáticos}

Os quadros seguintes apresentam o índice do manual de orientação ao professor em cada uma das obras. O primeiro quadro apresenta o índice do manual do professor do livro Física em Contexto.

\section{Quadro 5.1. - Índice resumido do Manual do professor, do livro Física em Contexto.}

\section{Ensino de Física e metodologia}

Por que ensinar/aprender Física hoje?

Metodologia e concepção da obra

Organização do volume

\section{Volume 1}

\section{Metodologia de trabalhos por projetos}

Projetos interdisciplinar

Exemplo de projeto: Redução de consumo de água na escola

Avaliação da atividade por projeto

Sugestão e indicações de projetos interdisciplinares no Volume 1 Referências bibliográficas

Fonte: Física em Contexto (PIETROCOLA et al., 2011).

O índice apresentado não está completo. Foram retirados os subtítulos que aparecem após "Volume 1" pois detalham o conteúdo da obra com sugestões de ação didática. Também foram retirados os detalhamentos das referências bibliográficas, pois não são interessantes para a presente discussão.

Na obra de Pietrocola (2011), é possível perceber uma grande preocupação com a metodologia utilizada no desenvolvimento dos conteúdos 
de Física. Uma discussão mais aprofundada sobre a componente curricular de Física é desenvolvida pelo autor. $\mathrm{O}$ autor da ênfase à metodologia de ensino por projetos, o que é indicado no próprio índice com exemplo de aplicação e avaliação de projetos interdisciplinares. Esta também é uma metodologia destacada no edital PNLD 2019.

$\mathrm{O}$ autor utiliza pouco os termos habilidades e competências. Um trecho importante é a discussão feita sobre a importância de um ensino que não seja meramente transmissivo, mas que possa ser construído pelo aluno de modo a ter real significado podendo ser aplicado em diversos contextos.

Tradicionalmente, o ensino de Física tem destacado os conteúdos conceituais como objetivos de aprendizagem. Mas os conceitos precisam se tornar ferramentas intelectuais para serem operacionais. Ou seja, os conceitos precisam ser incorporados à estrutura cognitiva dos alunos, de modo que os torne verdadeiros proprietários do conhecimento. Por isso, há mais recentemente um grande esforço para mostrar que os conceitos precisam ser desenvolvidos com as habilidades $e$ as competências para que sejam utilizados em diversas situações. (PIETROCOLLA, et al. 2011, p. 9)

É possível notar que o autor coloca o ensino por competências em contraposição ao ensino tradicional, de modo que este tem por objetivo o ensino dos conteúdos conceituais enquanto aquele tem esses conteúdos como ferramenta para que objetivos mais amplos possam ser alcançados em diversas situações, aplicando conhecimentos que foram realmente incorporados e não somente memorizados para um teste. Essa contraposição será retomada no capítulo 6 na discussão a respeito da visão de professores e professoras sobre o ensino por competências.

O autor utiliza novamente os termos "habilidades e competências" ao se referir à matriz Enem 2009, mas é interessante notar que são apresentadas apenas as competências e habilidades que dizem respeito à componente curricular de Física.

Embora não dê mais ênfase ao termo "competência", o desenvolvimento metodológico de Pietrocola (2011) enfatiza a problematização e a resolução de problemas por meio de situações. Embora não desenvolva profundamente a necessidade de que as situações sejam reais, ou muito próximas daquilo que o aluno enfrentaria na realidade, o autor retoma as ideias 
de Paulo Freire ao dizer que os "temas geradores [devem fazer] sentido ao educando, e por isso devem ser extraídos de seu mundo vivencial" (PIETROCOLA, 2011).

Pietrocola, baseado na obra de Delizoicov (1991 e 2001) e Delizoicov e Angotti (1992), divide o processo em "três momentos pedagógicos", a saber:

Problematização inicial, Organização do conhecimento, Aplicação do conhecimento.

A problematização inicial é o momento em que o problema em situação é apresentado para o aluno. Problema para o qual o aluno deverá apresentar uma resposta, ou solução.

$\mathrm{Na}$ Organização do conhecimento os estudantes devem ter clareza a respeito de quais são os conhecimentos necessários para a resolução do problema apresentado e é nesse momento que "se confrontam os conhecimentos que se acredita que o aluno já dispõe com os novos saberes a serem aprendidos" (PIETROCOLA, 2011, p. 13).

Por fim, é no momento da Aplicação do conhecimento que os estudantes, exercitando autonomia e atuação coletiva na trativa das situações enfrentadas, colocarão em prática os conhecimentos adquiridos fazendo uso de outras ferramentas necessárias para a resolução do problema.

A seguir é apresentado o quadro 2, que contém o índice do Manual do Professor da coleção Física para o Ensino Médio.

Quadro 5.2. - Índice resumido do Manual do professor, do ilivro Física para o Ensino Médio.

\section{Objetivos formativos}

Estatuto da Criança e do Adolescente (ECA)

Lei de Diretrizes e Bases da Educação (LDB)

Plano de Desenvolvimento da Educação (PDE)

Diretrizes Curriculares Nacionais para o Ensino Médio (DCNEM)

Parâmetros Curriculares Nacionais (PCN) - Ciências da Natureza, Matemática e suas tecnologias/Conhecimentos de Física

Orientação Educacionais Complementares aos Parâmetros Curriculares 
Nacionais $(\mathrm{PCN}+)$ - Física

Orientações Curriculares Nacionais (OCL)

Programa Ensino Médio Inovador

Sistema Nacional de Avaliação da Educação Básica (Saeb)

O Exame Nacional do Ensino Médio (Enem)

Programa Internacional de Avaliação de Estudantes (Pisa)

Projeto Político-Pedagógico da escola (PPP)

Planejamento das aulas

Síntese

\section{Conceitos refletidos na obra}

A escola

O aluno

O professor

A sala de aula

Abordagens

A avaliação

O conteúdo da Física

Materiais para suplementar a formação

Referências bibliográficas

Orientação por unidade

Fonte: Física para o Ensino Médio (YAMAMOTO, FUKE, 2010)..

Este índice também não é apresentado na íntegra. Foram excluídos os subtítulos após "Materiais indicados para suplementar a formação", pois não são relevantes para presente discussão.

O índice apresentado mostra uma diferença importante na abordagem apresentada pelos autores em relação à coleção anterior. É claramente mais detalhado e mostra uma preocupação dos autores em articular o ensino da Física com aquilo que é apresentado em documentos e currículos oficiais, pois apresenta na íntegra o conteúdo desses documentos. Também é uma 
preocupação dos autores aquilo que é esperado nos exames nacionais ou internacionais como Enem, que tem sua matriz de competências e habilidades apresentada também na íntegra, e o Pisa.

O texto de Yamamoto e Fuke (2010) se distancia bastante da abordagem de Pietrocola. Os autores fazem uma apresentação quase que integral de leis, diretrizes e programas de avaliação para depois discutir a concepção da obra, é apresentada logo no início quando tratam da relação entre aluno, conhecimento e escola e o papel do professor.

O aluno, integrante das duas realidades [a da escola e a da comunidade onde vive], conflita entre os objetivos de aprendizado que possui e os recebidos da escola, o que é minimizado ao se tomar o aprendizado como um caminho para o desenvolvimento daquilo que é significativo ao aluno, restritamente associado à cultura na qual ele se insere.

O professor tem como papel mediar a relação do aluno com o conhecimento [...] que busca auxiliar o aluno no desenvolvimento de seu aprendizado, tendo a sala de aula como um espaço catalisador desse processo de aprendizagem. Nesse processo, influem as abordagens conferidas às aulas, a avaliação realizada e o conteúdo da Física lecionado. (YAMAMOTO, FUKE, 2010, p. 26).

Ao tratar mais especificamente sobre o aluno que cursa o Ensino Médio, os autores fazem uma distinção entre a capacidade dos estudantes em obter informações, disponíveis nos mais diferentes meios, e a necessidade que a escola proveja articulação e aprofundamento desses conhecimentos.

Nosso aluno pode ver a execução de experimentos pela televisão e até entender as explicações associadas, mas dificilmente alcança um domínio que possibilite pensá-los, montá-los e executá-los. [...]”

O aluno deve adquirir uma formação que objetive, além dos resultados da ciência, o seu funcionamento, sua estrutura e que ela seja usada como meio para que os alunos desenvolvam capacidades cognitivas, motoras e construam valores e significados para orientálos e auxiliá-los no exercício da vida cidadã. (YAMAMOTO, FUKE, 2010, p. 27).

Outros pontos trabalhados são: a sala de aula, que segundo os autores é "o espaço no qual o processo de ensino aprendizado ocorre", abordagens e avaliação, que os autores trabalham em uma discussão sobre as definições de 
diferentes abordagens e tipos de avaliação. Especificamente sobre abordagem, os autores explicitam as características de sua obra, na qual

O texto apresenta os conceitos corretos de forma linearizada, característica do processo de didatização de conteúdos [...]. O texto privilegia o entendimento do conhecimento científico produzido pela Física, considerando que a linearização facilita o entendimento do aluno a respeito dos fenômenos, dos conceitos e teorias associados (YAMAMOTO, FUKE, 2010, p. 28).

\subsection{O Exame Nacional do Ensino Médio}

Em se tratando do ensino tradicional, não só a necessidade, mas as características da avaliação e de seus instrumentos são estruturadas de maneira bastante rígida. O sistema de ensino como um todo estabelece conteúdos e objetivos que devem ser atingidos pelo estudante. O professor é responsável por transmitir as informações e os procedimentos necessários. Ao estudante cabe registrar informações e treinar procedimentos de modo que seja capaz de reproduzi-los quando solicitado. Essa solicitação em geral acontece em uma prova escrita padronizada à qual os estudantes precisam responder sozinhos, e de maneira a reproduzir o mais fielmente possível o modelo a eles antes apresentado.

Em uma lógica de competências esse tipo de avaliação faz pouco sentido. Sobretudo porque desta forma não é possível observar o estudante em situação, avaliar se ele de fato mobilizou os recursos necessários para enfrentar a situação apresentada ou mesmo se ele dispõe de recursos outros que não apenas os cognitivos. A padronização de testes e a individualização das respostas é outro grande problema. As situações cotidianas poucas vezes possuem apenas uma alternativa como solução, e esta solução em geral é mais eficaz quando articulada entre diferentes pessoas, que contribuem de maneira complementar para solucionar a situação apresentada.

O principal teste do sistema de ensino brasileiro é o Exame Nacional do Ensino Médio (ENEM). Trata-se de um teste padronizado para todo o território nacional, no qual o aluno é avaliado de acordo com uma matriz de competências e habilidades. 
As competências e habilidades ganharam grande destaque por conta, principalmente, de serem apresentadas em matriz avaliativa do ENEM. Na primeira versão do exame, que vigorou de 1998 a 2008, são apresentadas 5 competências e 21 habilidades como matriz avaliativa que abrange todas as áreas de conhecimento. No novo ENEM, a partir de 2009, são apresentados 5 eixos cognitivos $^{23}$, de 6 a 9 competências e 30 habilidades para cada área de conhecimento. Desde sua criação, o ENEM tem sido um exame cada vez mais importante, concedendo aos candidatos, dentre outras coisas, a possibilidade de ingressar em universidades brasileiras e portuguesas ${ }^{24}$. Dessa forma a presença das competências e habilidades como conceitos centrais do ENEM, tem influenciado a produção de materiais didáticos, bem como 0 desenvolvimento de currículos em unidades escolares específicas. O conceito de competências está presente no texto dos PCN, que é o documento curricular na educação nacional. Após a publicação dos PCN, currículos de redes estaduais, e exames de menor abrangência como o Sistema de Avaliação de Rendimento Escolar do Estado de São Paulo (SARESP) buscaram uma organização de acordo com a lógica de competências. Contudo, a transposição do conceito de competências de um campo de conhecimento para outro, de referenciais teóricos para documentos oficiais de abrangência nacional, de documentos oficiais para práticas em sala de aula, não é tarefa simples.

A seguir apresentaremos o exame e discutiremos sobre os sentidos que nele assumem as competências. Para isso, inicialmente será necessário situar o contexto do Exame Nacional do Ensino Médio (ENEM), a partir de um breve histórico. Em seguida, e a partir de nossas análises anteriores, é possível identificar dois planos de abordagem em relação ao sentido das competências. O primeiro consiste em analisar de que forma as competências aparecem no discurso oficial, expressos na fundamentação teórica do exame. O segundo, trata de investigar de que forma as competências se concretizam nos exames propriamente ditos, ou seja, de que forma são consideradas nos itens das provas e na própria estrutura do exame.

${ }^{23}$ Os eixos cognitivos no novo ENEM são as competências apresentadas no antigo ENEM (PAIVA, 2014).

${ }_{24}$ Atualmente, são 28 as universidades portuguesas que aceitam o resultado do ENEM como forma de ingresso de brasileiros. Fonte: g1.globo.com. Acessado em 12 de mai de 2018. 


\subsubsection{Histórico e estrutura do ENEM}

O que aqui se apresenta, baseia-se em parte no que foi investigado anteriormente (PAIVA, 2014), recuperando alguns resultados, mas visando uma análise de natureza diferente da realizada naquela investigação.

O ENEM é uma avaliação pública brasileira que começou a ser aplicado em 1998, com o objetivo de avaliar a qualidade do ensino médio do sistema de ensino nacional (KIMURA, 2013) e contou, naquela época, com cerca de $157 \mathrm{mil}$ inscritos ${ }^{25}$. A prova fez parte de um primeiro conjunto de ações decorrentes da LDB/96, e objetivou utilizar os resultados do exame para dar direção às políticas públicas para a área de educação. A elaboração, aplicação e geração de dados a partir do ENEM são de responsabilidade do Instituto Nacional de Estudos e Pesquisas Anísio Teixeira (INEP).

Originalmente o ENEM era composto por 63 questões e uma redação que deveriam ser aplicadas em um único dia. Inicialmente a nota do ENEM era contabilizada de maneira clássica, ou seja, contagem do número de acertos em uma escala de 0 a 100. A nota do ENEM poderia ser utilizada para acrescentar alguma porcentagem aos pontos obtidos em vestibulares, como o da FUVEST, mas tinha como objetivo principal a avaliação individual dos concluintes do ensino médio, para que os dados gerados pudessem orientar as políticas públicas na educação.

A partir do ano de 2004 o ENEM passa a selecionar alunos para a obtenção de bolsas do Programa Universidade para Todos (PROUNI). Neste momento o ENEM inicia um processo de adição de objetivos em sua aplicação. Passa, em tese, a funcionar como prova de acesso para milhares de brasileiros ao ensino superior, embora a democratização desse acesso fosse questionável.

${ }^{25}$ Disponível em http://gestaoescolar.abril.com.br/aprendizagem/resultados-enem-muito-maisranking-avaliacao-762794. shtml?page=3 
O exame não democratiza o acesso ao Ensino Superior. Há evidências de que os alunos que têm bom desempenho no vestibular tradicional também têm no Enem. O perfil dos alunos aprovados é 0 mesmo.

Ocimar Munhoz Alavarse, professor da Universidade de São Paulo (USP)

Disponível em: http://gestaoescolar.org.br/ - Resultados do Enem: muito mais que um ranking. Acessado em: 06 Ago 2016.

O ENEM passa, então, a possuir um documento denominado Fundamentação teórico-metodológica para justificar seu modelo (BRASIL, 2005). Com base na LDB/96 e em documentos relacionados, como os Parâmetros Curriculares Nacionais para o Ensino Médio (PCN). O exame se propunha a uma avaliação de competências e habilidades, mas a fundamentação teórica do ENEM (BRASIL, 2005) apresenta, de forma mais clara e sistemática, como são definidos esses conceitos. Embora tanto a definição quanto a mensuração de competências e habilidades seja até hoje tema de discussão, a fundamentação teórica do ENEM procura sustentar tratar-se de um teste que avalia a formação de um indivíduo com uma visão mais ampla do mundo e da sociedade em que está inserido. De forma geral, buscava-se evitar a medição de conhecimento acumulado e passava-se a priorizar a capacidade de mobilização desses conhecimentos para avaliar, relacionar e propor soluções. O ENEM começa a se sagrar como o teste que valoriza o "raciocínio" ao invés da "informação decorada".

A partir do ano de 2009, passa por uma reforma significativa, passando a ser conhecido como "o Novo ENEM". Do ponto de vista de formato o exame passa a ter 180 questões e uma redação, para serem resolvidas em dois dias. A nota obtida pelo aluno passa, então, a ser estabelecida pela Teoria de Resposta ao Item (TRI). Trata-se de uma teoria estatística que leva em conta a calibração dos itens e o desempenho médio do aluno em questões do mesmo nível, em uma escala de notas que vai de zero até 1000 pontos (KIMURA, 2013). É feita inserção da avaliação de uma língua estrangeira ${ }^{26}$ e adotada uma especificidade maior dentro das áreas de conhecimento, estabelecidas na

\footnotetext{
${ }^{26}$ No ato da inscrição os candidatos devem optar se desejam responder às questões de inglês ou de espanhol.
} 
nova matriz (PEIXOTO, 2010). Também é adotada uma nova matriz de competências e habilidades que devem parametrizar a elaboração dos itens da prova.

Do ponto de vista de objetivos da prova, continuam valendo o levantamento de dados para implantação de políticas públicas e a avaliação de qualidade do Ensino Médio brasileiro. Mas, além disso, o candidato passa a poder utilizar o resultado como certificação de Educação de Jovens e Adultos (EJA) de nível médio. Mais decisivo ainda, do ponto de vista das mudanças introduzidas, é que seus resultados passam a ser considerados como forma de ingresso para as universidades federais brasileiras, através do Sistema de Seleção Unificada (SISU), além de tornar-se elemento importante para a classificação na concessão de bolsas do PROUNI ou para financiamento estudantil (FIES). A partir do ano de 2014, os candidatos podem utilizar o resultado do exame para ingresso em universidades portuguesas.

As reformas do ENEM, a partir do ano de 2009, com o uso da TRI e uma melhor definição e caracterização das competências e das habilidades esperadas, mostraram, em um primeiro momento, uma tentativa de adequação para que se pudesse avaliar o desenvolvimento de competências nos estudantes, muito embora essas novas definições tenham tornado as competências mais restritas.

\subsubsection{As competências na Fundamentação Teórico-} Metodológica do ENEM

Com base no PCN e nas DCN, a Fundamentação teórico-metodológica do ENEM (2005), apresenta parâmetros gerais que indicam a centralidade da avaliação das competências.

O Enem focaliza, especificamente, as competências e habilidades básicas desenvolvidas, transformadas e fortalecidas com a mediação da escola. (BRASIL, INEP, 2005, p. 8).

Este documento é desenvolvido por diversos autores, cada qual falando sobre alguma característica específica. Ao longo de todo o texto existe uma tentativa mais explícita de caracterizar e definir, ou ao menos esclarecer $o$ que se espera de um trabalho a partir dos conceitos de competências e 
habilidades. O trecho anterior mostra como o ENEM está organizado a partir destes conceitos. Isso exige que se adote alguma definição para o conceito, para que de maneira mais pragmática possa haver utilidade na aplicação do exame.

Competências são então definidas como o que se refere ao

julgamento ou interpretação, a partir de um conjunto de indicadores ou fatores presentes em uma determinada situação e que implicam na necessidade de uma decisão. Para isso, interessa mobilizar os recursos disponíveis para essa tomada de decisão (BRASIL, INEP, 2005).

A noção de tomada de decisão está intimamente ligada com a capacidade de enfrentamento de situações reais. Diante de uma situação real, o estudante deve ter desenvolvido a capacidade de mobilizar os recursos necessários e decidir como utilizá-los.

A centralidade da "situação" para o desenvolvimento das competências fica evidente de acordo com a definição anterior apresentada. Para Perrenoud (1999), as competências transversais, não eram indissociáveis necessariamente de determinada situação problema, mas a partir de diversas situações, seria possível extrair competências gerais que possibilitariam ao estudante solucionar situações diversificadas, em contextos outros e que exigissem o uso de determinada competência. Dessa forma, seria preciso despojar os verbos que caracterizariam uma ação, de um contexto específico, para que seu desenvolvimento geral provesse ao estudante a capacidade de aplicar tal competência em outro contexto.

Antes de 2009 a listagem de competências do ENEM era constituída por 5 competências e 21 habilidades (BRASIL, INEP, 2005). A listagem de competências do primeiro ENEM (mostrada a seguir) apresenta um caráter generalista, isto é, qualquer das competências poderia classificar questões de qualquer área do conhecimento, não havendo, portanto, divisão clara das áreas de conhecimento na organização das competências a elas atribuídas. 
Quadro 5.3. - Competências do antigo ENEM.

\begin{tabular}{|l|l|l|l|l|}
\hline Competência 1 & $\begin{array}{l}\text { Dominar a norma culta da Língua Portuguesa e fazer uso das linguagens } \\
\text { matemática, artística e científica. }\end{array}$ \\
\hline Competência 2 & $\begin{array}{l}\text { Construir e aplicar conceitos de várias áreas do conhecimento para a } \\
\text { compreensão de fenômenos naturais, de processos histórico-geográficos, da } \\
\text { produção tecnológica e das manifestações artísticas. }\end{array}$ \\
\hline Competência 3 & $\begin{array}{l}\text { Selecionar, organizar, relacionar, interpretar dados e informações representados } \\
\text { de diferentes formas, para tomar decisões e enfrentar situações problema. }\end{array}$ \\
\hline Competência 4 & $\begin{array}{l}\text { Relacionar informações, representadas de diferentes formas, e conhecimentos } \\
\text { disponíveis em situações concretas, para construir argumentos consistentes. }\end{array}$ \\
\hline Competência 5 & $\begin{array}{l}\text { Recorrer aos conhecimentos desenvolvidos na escola para elaboração de } \\
\text { propostas de intervenção solidária na realidade, respeitando os valores humanos } \\
\text { e considerando a diversidade sociocultural. }\end{array}$ \\
\hline
\end{tabular}

Fonte: INEP (BRASIL, 2005).

O documento, em sua discussão sobre interdisciplinaridade, fornece elementos que fundamentam a escolha de uma matriz generalista e que não explicita limites entre disciplinas ou áreas de conhecimento.

A insatisfação com a excessiva fragmentação a que o trabalho multidisciplinar tem conduzido é responsável pelo aparente consenso em torno da necessidade da interdisciplinaridade.

Associada a esse fato, cresce a consciência da necessidade de organização do trabalho escolar em torno de objetivos que transcendam os limites e os objetos das diferentes disciplinas, o que tem contribuído para situar no centro das atenções a idéia de transdisciplinaridade.

No mesmo sentido, consolida-se a sensação de que o conhecimento precisa estar a serviço da inteligência, e a transdisciplinaridade passa a significar o deslocamento do foco das atenções dos conteúdos disciplinares para os projetos das pessoas.

(BRASIL, INEP, 2005, p. 52)

Embora o quadro anterior apresente as competências com frases relativamente longas, existe nestas, um caráter generalista. As frases são sempre iniciadas por verbos que determinam uma ação que, a priori, poderia ser executada em qualquer contexto. Não existe relação direta entre as 
competências e um determinado contexto, ou mesmo matéria ou área de conhecimento.

É ostensivo o fato de os Parâmetros explicitarem as disciplinas, ainda que as articule dentro da área e ainda que busque compor essa última com as duas outras áreas, ao passo que o Enem não faz menção a qualquer disciplina, nem sequer a áreas de qualquer tipo.

(BRASIL, INEP, 2005, p. 64)

Embora posteriormente se discuta a importância de conhecimentos específicos relacionados às disciplinas, a frase anterior explicita a disposição do ENEM em uma apresentação geral a respeito do desenvolvimento dos saberes e da avaliação de competências.

O quadro 2, são apresentadas as competências, destacando-se os verbos que explicitam as ações relacionadas à determinada competência e o objeto ao qual as ações se referem.

\begin{tabular}{l|l|l} 
Quadro 5.4. - Competências do antigo ENEM mostrando o verbo de ação e o objeto ao qual o verbo se \\
refere.
\end{tabular}

Fonte: INEP (BRASIL, 2005).

A partir do ano de 2009, a prova foi dividida nas quatro áreas do conhecimento, a saber; Linguagens, Códigos e suas Tecnologias; Matemática e suas Tecnologias; Ciências da Natureza e suas Tecnologias; Ciências 
Humanas e suas Tecnologias. Cada área de conhecimento passa a conter de 6 a 9 competências. Será analisada de maneira mais específica a matriz relacionada à área de conhecimento de Ciências da Natureza e suas Tecnologias, que possui 8 competências e 30 habilidades.

Nessa nova fase do ENEM, é possível perceber uma maior especificidade das matrizes apresentadas. No quadro 3 são apresentadas as competências presentes na matriz do novo ENEM.

\section{Quadro 5.5. - Competências do novo ENEM}

\begin{tabular}{|c|c|}
\hline Competência 1 & $\begin{array}{l}\text { Compreender as ciências naturais e as tecnologias a elas associadas como } \\
\text { construções humanas, percebendo seus papéis nos produção e no desenvolvimento } \\
\text { econômico e social da humanidade. }\end{array}$ \\
\hline Competência 2 & $\begin{array}{l}\text { Identificar a presença e aplicar as tecnologias associadas às ciências naturais em } \\
\text { diferentes contextos. }\end{array}$ \\
\hline Competência 3 & $\begin{array}{l}\text { Associar intervenções que resultam em degradação ou conservação ambiental a } \\
\text { processos produtivos e sociais e a instrumentos ou ações científico-tecnológicos. }\end{array}$ \\
\hline Competência 4 & $\begin{array}{l}\text { Compreender interações entre organismos e ambiente, em particular aquelas } \\
\text { relacionadas à saúde humana, relacionando conhecimentos científicos, aspectos } \\
\text { culturais e características individuais. }\end{array}$ \\
\hline Competência 5 & $\begin{array}{l}\text { Entender métodos e procedimentos próprios das ciências naturais e aplicá-los em } \\
\text { diferentes contextos. }\end{array}$ \\
\hline Competência 6 & $\begin{array}{l}\text { Apropriar-se de conhecimentos da física para, em situações problema, interpretar, } \\
\text { avaliar ou planejar intervenções científico-tecnológicas. }\end{array}$ \\
\hline Competência 7 & $\begin{array}{l}\text { Apropriar-se de conhecimentos da química para, em situações problema, interpretar, } \\
\text { avaliar ou planejar intervenções científico-tecnológicas. }\end{array}$ \\
\hline Competência 8 & $\begin{array}{l}\text { Apropriar-se de conhecimentos da biologia para, em situações problema, interpretar, } \\
\text { avaliar ou planejar intervenções científico-tecnológicas. }\end{array}$ \\
\hline
\end{tabular}

Fonte: INEP (2013).

A matriz do novo ENEM revela um grau de especificidade maior do que a matriz anterior. A presença de listas diferentes para cada uma das áreas de conhecimento e o nome de disciplinas específicas na descrição das competências 6,7 e 8 , ilustram esse aumento de especificidade. 
A despeito disso, a própria associação do verbo com o objeto a que se refere revela uma menor abrangência e generalização das competências do novo ENEM, como é visto no quadro 4.

\begin{tabular}{|l|l|l|l|}
\multicolumn{2}{|c|}{ Quadro 5.6. - Competências do novo ENEM mostrando o verbo de ação e o objeto ao qual o } \\
verbo se refere.
\end{tabular}

Fonte: INEP (2013).

Em comparação com o Quadro 2, ○ Quadro 4 apresenta maior repetição de verbos específicos, tais como "Compreender" ou "Avaliar". Essa maior repetição decorre de que a compreensão se relaciona a um objeto mais específico, abarcando situações mais restritas.

Embora a matriz do novo ENEM apresente as antigas competências ao seu início, denominando-as como Eixos Cognitivos Comuns a Todas as Áreas de Conhecimento, percebe-se, entre o antigo e o novo ENEM, alterações tanto 
na noção de competência, especificando conhecimentos, quanto no conceito de interdisciplinaridade, explicitando disciplinas e restringindo a interdisciplinaridade às áreas de conhecimento.

É importante notar que, sendo o ENEM um exame em que se pretende avaliar a presença de competências, o formato dos itens apresentados nas provas do exame, procuram em certa medida obedecer os pontos apontados por Zabala e Arnau como importantes para a avaliação das competências. Um item ENEM deve ser contextualizado por meio de um texto-base, sobre o qual se faz um questionamento no enunciado sobre o qual, em geral, se espera que o aluno tome uma decisão. A decisão ${ }^{27}$ do aluno gera um indicador para os itens que vão afastá-lo ou aproximá-lo de uma determinada competência por meio da Teoria de Resposta ao Item (TRI). Ou seja, se dois sujeitos, realizando a prova, indicam respostas erradas à determinado item, um deles pode estar mais errado do que outro de acordo com os indicadores do item e das alternativas. Da mesma forma se esses sujeitos acertam um item específico, esta pode ter um peso maior ou menor em sua aproximação da competência com base no seu desempenho nos outros itens. Essa ferramenta de pontuação tenta aproximar a prova de uma espécie de variação de instrumentos ou meios de avaliação das competências.

Contudo, embora o ENEM tente se aproximar de uma avaliação por competências, o faz ignorando os limites de uma prova objetiva padronizada, que em última análise, impede a verificação das competências reais do estudante, pois este não está de fato enfrentando a situação, mas uma prova escrita.

\subsubsection{As competências na prova do ENEM}

Como dito anteriormente, procuraremos analisar a presença das competências no ENEM considerando duas dimensões. A primeira discutida na seção anterior diz respeito ao discurso Teórico-Metodológico do exame. Outra dimensão é a presença das competências na própria prova, mais especificamente em como as competências são percebidas nos itens da prova ENEM. Esta segunda análise é de natureza bem mais complexa, uma vez que

\footnotetext{
${ }^{27}$ Por se tratar de uma prova objetiva a decisão se revela pela alternativa escolhida.
} 
não há declaração explícita sobre qual competência é avaliada em cada item. Portanto, com base no que foi apresentado anteriormente neste capítulo e principalmente na discussão sobre competências do capítulo 2, procuraremos inferir a possibilidade de uma avaliação de competências nos itens da edição de 2013 do exame. Acreditamos que a prova de 2013 apresenta consolidação das alterações do novo ENEM. Dentre as quatro opções de cadernos (azul, rosa, branco e amarelo) selecionou-se o caderno amarelo da prova de ciências da natureza. Foi feita então uma seleção dos itens que se julgou que representam a disciplina de Física ${ }^{28}$. Foram selecionados 15 itens e serão numerados aqui de acordo com o número que consta no caderno amarelo do exame. A análise aqui apresentada é feita em Paiva (2015).

Até a seção anterior, nos referimos apenas ao termo competência, considerando competências mais amplas dos sujeito. Nesta seção no entanto será preciso fazer uso de outro termo importante no que diz respeito a um ensino por competências que são as "habilidades". Àquilo que Perrenoud (1999) chamou de "competências disciplinares", e que pode ser entendido como uma competência mais específica da ordem do fazer, o ENEM denomina "habilidade". Uma habilidade está sujeita a uma competência. Para a análise que seguirá, os itens serão classificados de acordo com as habilidades apresentadas na "Matriz de competências e habilidades do ENEM".

A ficha a seguir foi elaborada para classificar o item de acordo com os parâmetros que se julgou pertinentes para uma boa caracterização e classificação quanto ao conceito de competência. O modelo é apresentado com uma breve explicação sobre a função definida para cada categoria.

\footnotetext{
${ }^{28}$ Os nomes das disciplinas não aparecem para agrupar as questões, mas esse agrupamento é possível na maioria das questões com base no assunto e abordagem apresentados, tanto na contextualização quanto nas opções de resposta.
} 
Quadro 5.7.- Modelo da ficha desenvolvida para a classificação dos itens ENEM.

\begin{tabular}{|c|c|c|}
\hline \multirow[t]{9}{*}{ ENEM 2013 - QUESTÃO XX } & & \\
\hline & Tema & Temática geral do item. \\
\hline & Conteúdo 1 & Conteúdo disciplinar presente no item. \\
\hline & $\begin{array}{l}\text { Colocação da } \\
\text { pergunta }\end{array}$ & $\begin{array}{l}\text { Se a questão está clara e sem } \\
\text { dubiedades. }\end{array}$ \\
\hline & $\begin{array}{l}\text { Apresentação das } \\
\text { alternativas }\end{array}$ & $\begin{array}{l}\text { Se existe apenas uma alternativa } \\
\text { correta e se as alternativas erradas } \\
\text { não são demasiadamente atrativas. }\end{array}$ \\
\hline & Resolução & $\begin{array}{l}\text { Apresenta a resolução que se julga } \\
\text { correta para o item. }\end{array}$ \\
\hline & Avaliação & $\begin{array}{l}\text { Caracteriza a maneira que se julga que } \\
\text { o item funciona, ou que tipo de } \\
\text { resultado produz. }\end{array}$ \\
\hline & Habilidade & $\begin{array}{l}\text { Habilidade da matriz ENEM, que se } \\
\text { entende que melhor representa o } \\
\text { item. }\end{array}$ \\
\hline & Recurso & Competência geral atribuída ao item. \\
\hline
\end{tabular}

Fonte: Elaborado pelo autor.

$\mathrm{Na}$ ficha, à direita da questão estão parâmetros que caracterizam o item (tema, conteúdo, colocação da pergunta, apresentação das alternativas e resolução) ou o classificam (avaliação, habilidade e recurso).

A caracterização do item busca fornecer uma visão mais geral do formato do item. O tema diz respeito ao assunto geral do item, o conteúdo, ao conhecimento disciplinar que se percebe. Apresentação das alternativas e resolução, dizem respeito à, como se compreendeu a relevância do enunciado e a maneira mais prática e correta de se resolver a questão.

Os três últimos critérios dizem respeito à maneira como se compreendeu a função avaliativa do item, ou seja, o conhecimento ou habilidade que se julgou que o item exige para sua resolução. $O$ critério de avaliação, relaciona-se à característica principal do item, quanto ao tipo de resposta que produz. Quanto a este critério optou-se por ser classificado como: 
Tecnicista, se o item exige um domínio de conhecimentos técnicos de aplicação de fórmula ou de procedimentos próprios da disciplina de física ou da situação, e o resultado alcançado não implica necessariamente em uma atuação prática;

Interpretativa, se o candidato deve interpretar um fenômeno ou situação com base em conhecimentos disciplinares, objetivando uma explicação correta do acontecimento;

Transpositiva, se o candidato pode transferir o conhecimento de uma situação disciplinar para situações cotidianas mais abrangentes;

Prático, se o conhecimento disciplinar possibilita ao candidato a tomada de decisão sobre uma situação específica.

O critério habilidade refere-se a habilidade da nova matriz ENEM que melhor se adequa ao item. É importante salientar que o INEP não divulga a habilidade relacionada ao item, por isso a classificação apresentada não é oficial, mas particular deste trabalho.

O critério ação refere-se àquilo que se espera do candidato para a resolução do item. A escolha do termo é uma referência às definições apresentadas no capítulo 2, nas quais é necessário que em situação o sujeito realize uma ação eficaz em resposta a um problema. As categorias podem ser aproximadas de competências e foram desenvolvidas especificamente para esta classificação. Quanto aos recursos o item pode ser classificado como:

tomada de decisão, o candidato precisa, em alguma situação prática tomar uma decisão a partir do resultado obtido;

utilização de esquemas, o candidato pode utilizar esquemas disciplinares para resolver uma situação que tem aspectos semelhantes à situações clássicas, mas possui desafios e exige julgamentos específicos que resultam em uma compreensão mais adequada do fenômeno;

aplicação de fórmula, o candidato deve simplesmente recorrer à memória de modo a identificar dados e aplicar a fórmula relacionada ao conteúdo. O resultado possui um fim em si mesmo e não exige, ou não permite uma decisão posterior;

reprodução de conceitos, o candidato pode reproduzir conceitos básicos em situações canônicas, tais como assinalar o vetor força resultante em uma situação canônica. O recurso de memória é mais exigido do que uma análise crítica da situação, mas não é necessário o uso de fórmulas específicas, muitas vezes devido à natureza do problema. 
Embora todos os recursos sejam aqui tratados como competências, os dois primeiros (tomada de decisão e utilização de esquemas) serão considerados coerentes com os conceitos de competência apresentados nos fundamentos teóricos do ENEM (BRASIL, 2005). As duas últimas classificações (aplicação de fórmulas e reprodução de conceitos) serão consideradas não coerentes com os conceitos apresentados no documento (BRASIL, 2005).

É importante ressaltar também que o critério avaliação, possui comentários adicionais à classificação, que qualquer um dos critérios está sujeito a mais de uma classificação, e um determinado item nem sempre satisfaz completamente um critério a ele atribuído. A seguir é apresentado um exemplo de classificação. As fichas de classificação dos demais itens da prova de 2013 podem ser encontradas no Apêndice A. 


\section{ENEM 2013 - QUESTÃO 90}

Em um piano, o Dó central e a próxima nota Dó (Dó maior) apresentam sons parecidos, mas não idênticos. É possível utilizar programas computacionais para expressar o formato dessas ondas sonoras em cada uma das situações como apresentado nas figuras, em que estão indicados intervalos de tempo idênticos $(T)$.

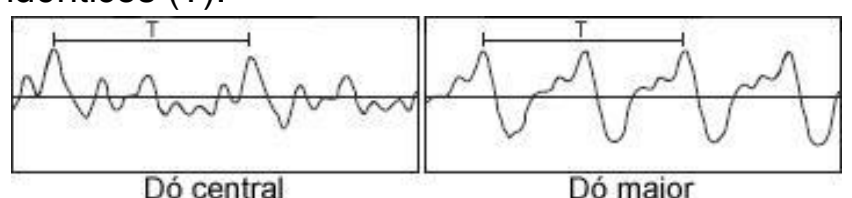

A razão entre as frequências do Dó central e do Dó maior é de:
a) $1 / 2$.
b) 2 .
c) 1 .
d) $1 / 4$.
e) 4 .

\begin{tabular}{|c|c|}
\hline Tema & Frequência de notas musicais \\
\hline Conteúdo 1 & Acústica \\
\hline Conteúdo 2 & Propriedades de ondas \\
\hline $\begin{array}{l}\text { Colocação da } \\
\text { pergunta }\end{array}$ & $\begin{array}{l}\text { A pergunta é clara, mas a construção não } \\
\text { tem gancho sintático com as alternativas. }\end{array}$ \\
\hline $\begin{array}{l}\text { Apresentação } \\
\text { das alternativas }\end{array}$ & A ordenação é por algarismo. \\
\hline Resolução & $\begin{array}{l}\text { No primeiro gráfico o intervalo de tempo } \\
\text { indicado abarca um comprimento de onda. } \\
\text { No segundo gráfico são abarcados dois } \\
\text { comprimentos de onda. Isso indica que } \\
\text { houve um aumento de duas vezes na } \\
\text { frequência do primeiro em relação ao } \\
\text { segundo gráfico. }\end{array}$ \\
\hline Avaliação & $\begin{array}{l}\text { Tecnicista. O contexto poderia ser qualquer, } \\
\text { e não é relevante para a resolução do } \\
\text { problema. Nem mesmo os eixos são } \\
\text { nomeados o que torna o foco do exercício } \\
\text { bem mais vago, podendo as oscilações } \\
\text { apresentadas referir-se a qualquer coisa. O } \\
\text { item testa apenas a capacidade do aluno de } \\
\text { reconhecer um padrão ondulatório e aplicar } \\
\text { a equação que relaciona velocidade de uma } \\
\text { onda comprimento de onda e frequência. } \\
\text { Não é relevante para o cotidiano do aluno e } \\
\text { dificilmente o faz refletir sobre sua visão de } \\
\text { mundo e de ciência. }\end{array}$ \\
\hline Habilidade & $\begin{array}{l}\text { H01- Reconhecer características ou } \\
\text { propriedades de fenômenos ondulatórios ou } \\
\text { oscilatórios, relacionando-os a seus usos em } \\
\text { diferentes contextos. }\end{array}$ \\
\hline Ação & Aplicação de fórmula \\
\hline
\end{tabular}

Fonte: Elaborado pelo autor. 


\subsubsection{Análise conjunta dos itens}

O objetivo da classificação foi selecionar os critérios que pudessem fornecer uma comparação consistente entre o conceito de competência, como apresentado na fundamentação teórica do ENEM (BRASIL, 2005), e o que se observa na prática do exame. Embora a análise dos itens pudesse ser feita de diversas maneiras, optou-se por restringir esta análise ao último critério (recurso). Entende-se que a análise deste critério fornece uma melhor base de comparação entre os conceitos de competência como se buscou fazer.

A matriz a seguir apresenta resumidamente a distribuição das habilidades contra as ações esperadas para cada item. Os números na matriz correspondem aos itens analisados. Dessa forma a posição vertical do número do item indica a habilidade a ele atribuída e sua posição horizontal indica a ação necessária para resolução.

Quadro 5.8. - Matriz de classificação dos itens em habilidades do novo ENEM e competências de avaliação. Os números da matriz referem-se ao número do item de acordo com o apresentado nas fichas acima.

\begin{tabular}{|l|c|c|c|c|}
\hline & $\begin{array}{c}\text { Tomada de } \\
\text { decisão }\end{array}$ & $\begin{array}{c}\text { Utilização de } \\
\text { esquemas }\end{array}$ & $\begin{array}{c}\text { Aplicação de } \\
\text { fórmula }\end{array}$ & $\begin{array}{c}\text { Reprodução de } \\
\text { conceitos }\end{array}$ \\
\hline $\begin{array}{l}\text { H1 Reconhecer } \\
\text { fenômenos ondulatórios }\end{array}$ & & & 53,90 & 87 \\
\hline $\begin{array}{l}\text { H3 Confrontar } \\
\text { interpretações }\end{array}$ & & 81 & & \\
\hline H5 Dimensionar circuitos & & & 84,67 & \\
\hline H6 compreender manuais & 66 & 48,79 & \\
\hline $\begin{array}{l}\text { H17 Relacionar } \\
\text { informações }\end{array}$ & & & \\
\hline $\begin{array}{l}\text { H18 Relacionar } \\
\text { propriedades }\end{array}$ & 69 & 55,60 & 65,76 \\
\hline $\begin{array}{l}\text { H21 interpretar } \\
\text { processos }\end{array}$ & & & \\
\hline
\end{tabular}

Fonte: Elaborado pelo autor.

Dos 15 itens analisados, 6 foram classificados com o recurso aplicação de fórmula, destes, quatro foram relacionados com habilidades que restringem conteúdos específicos, a saber, $\mathrm{H} 1$, que se relaciona com conteúdos de ondulatória e H5 que se relaciona com conteúdos de circuitos. 
Embora H18 seja uma habilidade mais abrangente, entende-se que a abordagem utilizada privilegia recursos de memória e exige que o candidato saiba utilizar as fórmulas relacionadas. Para ilustrar, a seguir é apresentado parte do enunciado da questão 65.

Desprezando o atrito e considerando uma aceleração gravitacional de $10 \mathrm{~m} / \mathrm{s}^{2}$, deseja-se elevar uma pessoa de $65 \mathrm{~kg}$ em uma cadeira de rodas de $15 \mathrm{~kg}$ sobre a plataforma de $20 \mathrm{~kg}$.

Qual deve ser a força exercida pelo motor da bomba sobre o fluido, para que o cadeirante seja elevado com velocidade constante?

(Questão 65, caderno amarelo, ENEM 2013)

No inicio da questão é apresentado um contexto, mas que não é necessário para a resolução que pode ser feita a partir dos valores do enunciado. A questão também não exige do candidato, qualquer tipo de reflexão, mas tão somente a obtenção de um valor de força que pode ser atribuído a diversas situações. Dessa forma entende-se que o principal objetivo do item é determinar se o candidato é capaz de selecionar os valores importantes e utilizá-los da maneira correta na fórmula adequada.

Houve também um considerável número de itens classificados com o recurso utilização de esquemas. Mesmo em habilidades com características mais disciplinares como H5 é possível desenvolver itens que exigem a utilização de esquemas constituídos. Para exemplificar, a seguir é apresentado parte do enunciado da questão 81 .

Um chuveiro projetado para funcionar em $110 \mathrm{~V}$ pode ser adaptado para funcionar em $220 \mathrm{~V}$, de modo a manter inalterada sua potência.

Uma das maneiras de fazer essa adaptação é trocar a resistência do chuveiro por outra, de mesmo material e com o(a)

(Questão 81, caderno amarelo, ENEM 2013)

É importante que o aluno utilize um esquema constituído, que é a utilização da fórmula relacionada, mas os valores apresentados não são o foco 
para a resolução do problema. A resposta trará uma noção mais completa a respeito do funcionamento do chuveiro, portanto o aluno precisa interpretar 0 comportamento do resultado a partir da fórmula, e não simplesmente aplicá-la e obter um resultado. Mas não é preciso que o aluno tome uma decisão sobre a situação, simplesmente é buscada uma explicação correta sobre o funcionamento de um aparato tecnológico, a partir de um esquema procedimental previamente constituído.

\subsection{Considerações preliminares}

Procuramos verificar a presença do conceito de competência em diversos âmbitos do sistema educacional brasileiro, buscando considerar as diferentes abordagens e sentidos atribuídos a este conceito. Desde a LDB/96, passando pelas Diretrizes, PCN e pela BNCC, até chegar ao manual didático, material com o qual o professor possivelmente terá maior contato. É importante também a presença das competências nos exames oficiais como o ENEM.

Existe, portanto, uma presença quase que universal das competências nos diversos âmbitos do sistema educacional brasileiro. Isso pode gerar uma sensação de homogeneidade e coerência nos discursos, o que não necessariamente é verdadeiro. O uso do termo "competência" não indica necessariamente que a postura de um ensino por competência está sendo assumida, assim como sua ausência não significa necessariamente 0 abandono dessa postura. Embora a última versão da BNCC se baseie fortemente nas competências, as primeiras versões deste documento não apresentavam o termo, embora o conceito estivesse presente. Por outro lado, o Manual do Professor do livro Física para o Ensino Médio apresenta o termo, em grande parte por conta da exibição integral dos textos de currículos e outros documentos oficiais, mas é difícil perceber a adoção de posturas realmente relacionadas ao ensino por competências no restante do texto.

Quando o próprio ENEM é analisado com mais cuidado, sua proposta, em alguns momentos, se aproxima mais das características de um ensino tradicional, a despeito do uso intenso do termo "competências". O fato de existir uma listagem fechada de competências, de se tratar de uma avaliação de questões objetivas apenas e de os sujeitos não serem avaliados em situação, 
contraria em diversos pontos as competências discutidas no capítulo 2. E é o ENEM que em grande medida influencia no desenvolvimento de materiais didáticos, no currículo das escolas e na prática de professores.

É possível perceber, portanto que o conceito de competência assume sentidos diversos, nos mais diferentes âmbitos do sistema de educação. Tornase mais evidente, portanto a necessidade de clarificação com relação a qual sentido se atribui às competências em âmbitos específicos. É, portanto prematuro pensar que a ocorrência do termo em diferentes âmbitos indica homogeneidade do discurso. É preciso cuidado na análise de documentos, materiais e exames, na tentativa de compreender de maneira um pouco mais precisa, o sentido que ali é atribuído às competências, e dessa forma evitar grandes discrepâncias de entendimento, discurso e ação. 


\section{AS COMPETÊNCIAS NA VISÃO DE DOCENTES}

Os capítulos anteriores trataram de características gerais do conceito de competência. De maneira mais ampla, a presença das competências em diferentes campos do conhecimento, como psicologia, ciências do trabalho, linguística e educação.

O uso desse conceito em diferentes campos de conhecimento, implica em diferentes sentidos a ele atribuídos. Contudo, ao aprofundar a pesquisa sobre o conceito de competências especificamente no campo da educação, foram verificados entendimentos diferentes dentro dessa mesma área de conhecimento, embora elementos comuns também tenham sido percebidos.

É claro que, em relação aos trabalhos teóricos, algumas características a respeito das competências recebem novos sentidos quando se analisam os documentos oficiais, os currículos, os manuais didáticos e também os instrumentos de avaliação. Outras características são suprimidas ou acrescentadas quando se verifica os sentidos das competências em diferentes âmbitos. Contudo, nenhum desses níveis da estrutura educacional é tão impactante para o ensino quanto a visão do professor. 
É a visão do professor, seu preparo e sua formação, a respeito das competências (assim como a respeito de qualquer outra visão educativa), que determinarão de fato como o processo de ensino-aprendizagem se dará em sala de aula. $O$ professor deve respeitar diversos parâmetros e exigências básicas, contudo, pode acabar por ignorar ou ressaltar determinados aspectos da teoria, das diretrizes educacionais, do currículo e sobretudo dos manuais didáticos, quando planeja sua aula e tem em mente não só a seleção daquilo que será levado aos alunos, mas também a forma como se dará esse processo, desde a proposta inicial até o momento da avaliação ${ }^{29}$.

O fato de o professor ignorar ou ressaltar determinados aspectos, especialmente do currículo, pode acontecer por algumas razões: $O$ professor pode simplesmente não conhecer o conteúdo desses materiais, entendendo (talvez por questões de praticidade) apenas o mínimo do que precisa ser cumprido. Outra possibilidade é que o professor de fato conhece os conteúdos, teorias e métodos desses materiais, mas escolhe, deliberadamente, não adotar determinadas posturas expressas no texto, pois não acredita que serão a melhor escolha para seus estudantes. Também é possível que os professores conheçam o conteúdo dos documentos oficiais, currículos, manuais e possivelmente discussões teóricas. Podem até acreditar que os conceitos e práticas recomendados seriam interessantes para seus estudantes, mas não os colocam em prática por limitações que podem ser materiais (falta de ferramentas, equipamentos e espaços adequados), de formação (não receberam formação específica sobre o tema e por isso não se sentem seguros para tentar mudanças nesse sentido) ou sociais (podem existir pressões específicas da comunidade escolar, que cobra do professor determinados resultados que podem ser de difícil obtenção caso mude suas estratégias).

Neste capítulo será apresentado um levantamento, feito por meio de questionário, e que procurou obter informações sobre qual é a visão e as práticas dos professores em relação às competências. Será feita uma caracterização da pesquisa e em seguida serão apresentados os resultados colhidos.

${ }^{29}$ Excetuando-se as avaliações oficiais, como o ENEM, já que esse tipo de avaliação não pode ser influenciada pelo professor, embora a maneira como se dá essa avaliação pode influenciar na conduta e planejamento do professor, que pode pautar suas escolhas de conteúdo e de percurso com base naquilo que acontece nos testes oficiais. 


\subsection{Contexto e desenho da pesquisa}

A pesquisa aconteceu no campus Cidade Universitária da Universidade de São Paulo em julho de 2017. Aconteceu na ocasião o 14ํㅡㄹ Encontro USP Escola, evento que oferece gratuitamente cursos de atualização para professores e professoras de diversas disciplinas do Ensino Médio ${ }^{30}$ nos meses de Janeiro e Julho desde 2007.

$\mathrm{Na}$ ocasião, além de palestras, foram oferecidos aos professores e professoras 19 cursos a respeito de diversos temas relacionados ao ensino de ciências, ministrados em diversos institutos do campus, a saber: Instituto de Física (IFUSP), Instituto de Química (IQUSP), Instituto de Ciências Biológicas (IBUSP) e Instituto de Astronomia e Geociências (IAGUSP).

A investigação feita teve como ferramenta de coleta de dados a aplicação de um questionário que procurava obter a visão dos professores e professoras a respeito do conceito de competências. Para a aplicação desse questionário, considerando o foco deste trabalho, procuramos selecionar cursos que tivessem relação com o ensino Física, para então solicitar autorização ao docente responsável para a aplicação do questionário. Todas as autorizações solicitadas foram concedidas pelos docentes fazendo com que o questionário fosse aplicado nos seguintes cursos: Relatividade Restrita, com 12 respondentes; História dos Sistemas Energéticos e Seus Impactos Ambientais, com 10 respondentes; Curso de Óptica: Teoria e Experimentos com 15 respondentes; Ensino de Química por Competências e Habilidades: do Senso Comum às Práticas ${ }^{31}$ com 28 pessoas que responderam ao questionário. É possível que as respostas obtidas apresentem variação de acordo com o curso no qual o questionário foi distribuído, contudo neste trabalho, essa especificidade não foi considerada no momento da análise.

De acordo com o pedido dos docentes, o questionário foi aplicado ao final do dia, com exceção do curso sobre Ensino de Química, no qual o questionário foi aplicado logo após o intervalo. Em todos os casos, foi

${ }^{30} \mathrm{http}: / /$ portal.if.usp.br

${ }^{31}$ Embora este curso não esteja diretamente relacionado ao ensino de Física, possui relação direta com o ensino por Competência. 
disponibilizado um tempo para explicar os objetivos da pesquisa e orientar o preenchimento do questionário.

O questionário foi estruturado em três seções. Na primeira, "EM QUE CONSISTE O ENSINO-APRENDIZAGEM POR COMPETÊNCIAS?" foram apresentadas as seguintes questões:

A. Quais elementos indicariam a ênfase em competências (e não apenas nos conteúdos) no processo de ensino-aprendizagem?

B. Os objetivos de um ensino tradicional, afinal, são os mesmos de um ensino por competências?

São questões abertas que buscavam perceber os elementos que, na visão dos professores e professoras, identificam um processo de ensinoaprendizagem por competências.

Foi também apresentada uma questão $\mathrm{C}$, que pedia aos professores que classificassem como;

[de] nenhuma importância (nível 1),

pode ser usado, mas é dispensável (nível 2),

é recomendado, mas não essencial (nível 3)

é essencial para trabalhar com competências (nível 4),

em relação à sua relevância para o ensino de competência, uma série de termos, tais como: contexto, interdisciplinaridade, provas dissertativas etc. Todos os termos apresentados, bem como as classificações dadas pelos professores, podem ser encontradas nos Apêndices B e C.

A segunda seção "IDENTIFICANDO COMPETÊNCIAS" possuía o mesmo objetivo da primeira, mas foi apresentada de modo que a visão do professor pudesse ser inferida de modo mais subjetivo a partir da classificação de um material. Foi apresentado um item, utilizada na edição 2013 do ENEM, que deveria ser classificado como capaz de avaliar competências ou não.

$\mathrm{Na}$ última seção "COMPETÊNCIAS NA ATIVIDADE DOS PROFESSORES" a tentativa foi de identificar qual a relação com o conceito de competência o professor ou professora tem em sua prática, no seu ambiente 
de atuação. Aqui a principal questão foi sobre o uso das competências no dia a dia do professor ou professora. As questões apresentadas foram

A. Em sua experiência como docente, quais contatos você já teve com coisas/situações nas quais havia elementos que apontavam para um ensino por competências?

$\square$ Em escola onde trabalhou $\square$ No livro didático que adotou

$\square$ Em material didático que usou $\square$ Outros:

$\square$ Nunca me deparei com coisas/situações do tipo.

B. Você já trabalhou por competências? As escolas em que atuou sinalizavam para um efetivo trabalho nessa direção? Já recebeu/encontrou orientação específica sobre como fazer isso? Valeria a pena? O que contribui para que professores e professoras trabalhem por competências? O que é um empecilho?

Nas análises apresentadas a seguir, são consideradas apenas as seções 1 e 3 . As respostas apresentadas às questões da segunda seção não pareceram relevantes para a discussão deste trabalho. A classificação de um item ENEM pode ser objeto de controvérsia mesmo entre especialistas. Além disso, o fato de o item apresentado ser um item de Física pode ter causado confusão para alguns docentes que não são especialistas nesta disciplina, o que não necessariamente influenciaria sua visão a respeito das competências, mas poderia influenciar seu julgamento a respeito daquele item específico.

O questionário completo pode ser encontrado no Apêndice $B$, bem como a tabulação de respostas apresentada no Apêndice C. Foram obtidas 65 respostas de professores e professoras de Biologia, Física, Química e Matemática que possuíam entre 1,5 e 33 anos de experiência em sala de aula. Quase $78 \%$ dos professores e professoras lecionavam em escolas públicas e cerca de $31 \%$ lecionavam disciplinas diferentes daquela para a qual haviam se formado. Dos 24 professores que lecionavam a disciplina de Física, apenas 12 possuíam formação específica. 


\subsection{Matriz de análise: delimitando perfis dos professores e professoras}

Aqui serão apresentadas algumas questões, e respostas obtidas, às quais julgamos significativas para análise neste trabalho. Para esta análise foi elaborada uma tabela que permite classificá-las em relação ao seu nível de proximidade do conceito de competências. A seguir, procuraremos apresentar essa tabela procurando descrever o processo para sua elaboração, assim como algumas respostas que exemplificam os critérios adotados. Depois disso retomaremos as questões apresentadas, mas com um olhar baseado nas categorias e perfis apresentados na tabela.

Considerando o resultado bastante variado, procurou-se identificar elementos comuns, que pudessem agrupar e classificar as respostas obtidas de modo a revelar a postura dos professores.

Percebeu-se que termos anteriormente apresentados neste trabalho, tiveram uma presença importante nas respostas. A ideia de interdisciplinaridade, a autonomia ou pensamento crítico, e contexto foram elementos bastante presentes nas respostas.

Embora as palavras, sejam citadas em diversas respostas, o simples uso dos termos não necessariamente revela o pensamento do professor ou da professora acerca do conceito de competências. Em verdade, assim como discutido no capítulo 1 , o próprio conceito de competência possui uma multiplicidade de sentidos, dessa forma não deve ser surpreendente que os elementos que o constituem possam assumir diferentes sentidos.

Alguns professores, por exemplo, revelavam em suas respostas uma preocupação grande com o desenvolvimento cognitivo do estudante em relação às situações escolares, outros revelavam um olhar mais cuidadoso para o desenvolvimento do pensamento crítico e da autonomia dos estudantes. Para alguns, essa autonomia se revela na capacidade de o estudantes buscar informações específicas para resolver um determinado problema, para outros a autonomia prepara o estudante para enfrentar situações no mundo real.

Dessa forma, em uma primeira aproximação das respostas, foram destacados termos que entendemos serem relevantes para a caracterização da 
visão dos professores e professoras, por estarem de alguma maneira relacionados aos elementos da arquitetura das competências discutidos no capítulo 2 deste trabalho, e que de alguma forma eram comuns nas respostas. Os termos destacados deram origem às categorias: $O$ Aluno, Saberes, Contexto, Autonomia, Experimentação, O Mundo, Interdisciplinaridade, Avaliação. Nem todos os professores citaram todos os termos Além disso, o fato de serem esses termos citados não significou uma convergência de visão dos professores e professoras. A articulação desses termos é que indicava os diferentes tipos de visão dos professores, independente de sua aprovação em relação ao ensino por competências. Dessa forma procuramos desenhar perfis que pudessem ajudar a classificar cada uma das categorias de acordo com a visão apresentada nas respostas.

Com relação ao que foi apresentado no capítulo 2, é possível constatar que as propostas de ensino por competências, em grande medida, procuram ser alternativas aos elementos do ensino tradicional. Tentamos portanto compreender se nas respostas apresentadas a visão dos professores seria de caráter mais tradicional ou mais alinhado com as competências. Com base nisso, elaboramos dois perfis opostos, sendo que o primeiro perfil, Tradicional, indica as respostas de caráter tradicional e com um olhar mais voltado para a comunidade escolar, enquanto o perfil de Competência indica as respostas que possuem um caráter mais alinhado ao conceito de competência e com o olhar voltado para o desenvolvimento geral da sociedade, segundo 0 entendimento que obtivemos a partir da discussão do capítulo 2. Embora em pequeno número, algumas respostas revelaram um caráter fortemente tradicional que de acordo com Aranha (1990) está "preocupada em transmitir a maior quantidade possível do conhecimento acumulado, apresentando-se portanto de forma predominantemente intelectualista e livresca" (ARANHA, 1990 , p. 108). Por outro lado, outras respostas pareciam bastante alinhadas com os conceitos de competências discutidos anteriormente. Ressaltamos que, não é a simples utilização de termos relacionados ou mesmo da aprovação do respondente em relação às competências que classifica sua resposta. Mas buscamos elementos mais amplos que possam caracterizar sua visão quanto ao conceito. Considerando as categorias e os perfis desenvolvidos, foi elaborado o seguinte quadro. 
Quadro 6.1. - Classificação simplificada de perfil dos professores e professoras para as categorias definidas a partir das respostas ao questionário de pesquisa.

\begin{tabular}{|c|c|c|}
\hline & Tradicional & Competência \\
\hline $\mathrm{O}$ aluno & $\begin{array}{l}\text { E capaz de reproduzir conceitos e } \\
\text { processos. }\end{array}$ & $\begin{array}{l}\text { E capaz de intervir na sociedade em } \\
\text { situações reais para promover respostas } \\
\text { eficazes. }\end{array}$ \\
\hline Saberes & $\begin{array}{l}\text { São um corpo constituído, de natureza } \\
\text { cognitiva, são fornecidos pelo professor e } \\
\text { materiais oficiais e devem ser } \\
\text { reproduzidos. }\end{array}$ & $\begin{array}{l}\text { São de naturezas múltiplas, obtidos a partir } \\
\text { de diversas fontes, dinâmicos e podem ser } \\
\text { produzidos pelo sujeito. }\end{array}$ \\
\hline Contexto & Ilustra a aplicação de um conceito. & $\begin{array}{l}\text { E essencial que seja real para o } \\
\text { desenvolvimento e manifestação das } \\
\text { competências, sendo significativo para o } \\
\text { sujeito e a comunidade. }\end{array}$ \\
\hline Autonomia & $\begin{array}{l}\text { Com as informações fornecidas o sujeito } \\
\text { é capaz de apresentar respostas aos } \\
\text { problemas propostos. }\end{array}$ & $\begin{array}{l}\text { Desenvolve no sujeito capacidade de, de } \\
\text { forma, crítica, estudar uma situação real, } \\
\text { propor uma solução e executá-la de forma } \\
\text { eficaz em seu raio de ação. }\end{array}$ \\
\hline Experimentação & $\begin{array}{l}\text { É importante para confirmar conceitos. } \\
\text { Pode servir como contexto. }\end{array}$ & $\begin{array}{l}\text { É parte do processo de resolução da } \\
\text { situação, que só é real, pois dela e nela se } \\
\text { experimenta. }\end{array}$ \\
\hline O Mundo & $\begin{array}{l}\text { É preciso, a partir da escola, ensinar o } \\
\text { sujeito a ler o mundo. }\end{array}$ & $\begin{array}{l}\text { É preciso que com a escola o sujeito leia e } \\
\text { intervenha no mundo de forma crítica. }\end{array}$ \\
\hline Interdisciplinaridade & $\begin{array}{l}\text { Uma disciplina pode referir-se a outra ou } \\
\text { tomar conhecimentos próprios de outra } \\
\text { disciplina na resolução de problemas } \\
\text { específicos. }\end{array}$ & $\begin{array}{l}\text { O mundo real é essencialmente não } \\
\text { disciplinar, por isso uma separação do } \\
\text { conhecimento por disciplinas faz pouco } \\
\text { sentido para o desenvolvimento de } \\
\text { competências. }\end{array}$ \\
\hline Avaliação & $\begin{array}{l}\text { Apresentar, em geral de forma escrita, } \\
\text { resolução de problemas aplicando } \\
\text { conceitos e procedimentos corretos. }\end{array}$ & $\begin{array}{l}\text { Solução eficaz e socialmente aceita para } \\
\text { uma situação. }\end{array}$ \\
\hline
\end{tabular}

Fonte: Elaborado pelo autor.

Uma vez elaboradas as categorias opostas, foi feita uma tentativa de classificar as respostas como de perfil Tradicional ou [de] Competência. Nessa tentativa foi possível constatar que grande parte das respostas não se enquadraria em nenhuma das duas categorias binárias ou, devido às contradições e complexidades reveladas, poderiam ser enquadrada nas duas. Foi preciso então elaborar perfis intermediários que pudessem classificar de maneira um pouco mais precisa essas respostas. 
Dessa forma, uma análise mais cuidadosa das respostas indicou a possibilidade de elaboração de mais dois perfis. O perfil TradicionalRenovado que indica uma visão ainda tradicional, mostrando grande preocupação com o desenvolvimento cognitivo do sujeito, mas da a ele alguma autonomia e possibilidade de inovação. Esta autonomia deve ser direcionada para os objetivos de aprendizado da disciplina, permitindo novas abordagens para práticas tradicionais de avaliação, como apresentar textos "contextualizadores" para questões escritas.

O perfil de Competência-Institucional indica respostas progressistas, mas ainda voltadas fortemente para o ambiente escolar. Revela um olhar do ensino sobre o mundo, mas ainda preocupado com as estruturas escolares. É cognitivo, mas admite outros saberes, como o procedimental. Procura desenvolver visão um pouco mais crítica nos sujeitos e formas diferenciadas de avaliação embora essas, ainda sejam bem marcadas.

Portanto, para classificar, agrupar, e eventualmente quantificar as categorias de competência observadas nas respostas ao questionário, foram utilizadas os perfis: Tradicional, Tradicional-Renovado, de CompetênciaInstitucional e de Competência.

O quadro 2 a seguir, apresenta as categorias e os perfis de acordo com a elaboração descrita. Nem todas as categorias de competência possuem exemplos de respostas para todos os perfis, sobretudo os perfis Tradicional e de Competência, mais extremos. Mas a classificação das respostas de acordo com essa tabela permite perceber o quão variadas podem ser as visões a respeito das competências.

Quadro 6.2. - Classificação completa de perfil dos professores e professoras para as categorias definidas a partir das respostas ao questionário de pesquisa.

\begin{tabular}{|l|l|l|l|l|}
\hline Tradicional & $\begin{array}{l}\text { Tradicional } \\
\text { Renovado }\end{array}$ & $\begin{array}{l}\text { Competência } \\
\text { Institucional }\end{array}$ & Competência \\
\hline O aluno & $\begin{array}{l}\text { É capaz de } \\
\text { reproduzir } \\
\text { conceitos e } \\
\text { processos. }\end{array}$ & $\begin{array}{l}\text { Enfrenta situações } \\
\text { escolares com } \\
\text { independência. Sabe } \\
\text { "aprender" sozinho. }\end{array}$ & $\begin{array}{l}\text { Relaciona conceitos e } \\
\text { procedimentos de } \\
\text { maneira teórica com } \\
\text { acontecimentos } \\
\text { cotidianos. }\end{array}$ & $\begin{array}{l}\text { É capaz de intervir na } \\
\text { sociede ed para promover } \\
\text { reaspostuas eficazes. }\end{array}$ \\
\hline
\end{tabular}


Quadro 6.2. - Classificação completa de perfil dos professores e professoras para as categorias definidas a partir das respostas ao questionário de pesquisa.

\begin{tabular}{|c|c|c|c|c|}
\hline & Tradicional & $\begin{array}{l}\text { Tradicional } \\
\text { Renovado }\end{array}$ & $\begin{array}{l}\text { Competência } \\
\text { Institucional }\end{array}$ & Competência \\
\hline Saberes & $\begin{array}{l}\text { São um corpo } \\
\text { constituído, de } \\
\text { natureza } \\
\text { cognitiva, são } \\
\text { fornecidos pelo } \\
\text { professor e } \\
\text { materiais oficiais } \\
\text { e devem ser } \\
\text { reproduzidos. }\end{array}$ & $\begin{array}{l}\text { São de natureza } \\
\text { cognitiva, mas se } \\
\text { desenvolvem com a } \\
\text { prática. Podem ser } \\
\text { "descobertos" pelo } \\
\text { sujeito. }\end{array}$ & $\begin{array}{l}\text { São de natureza } \\
\text { cognitiva e } \\
\text { procedimental. } \\
\text { Provém de diversas } \\
\text { fontes e auxilia o } \\
\text { sujeito em sua leitura } \\
\text { de mundo. }\end{array}$ & $\begin{array}{l}\text { São de naturezas } \\
\text { múltiplas, obtidos a partir } \\
\text { de diversas fontes, } \\
\text { dinâmicos e podem ser } \\
\text { produzidos pelo sujeito. }\end{array}$ \\
\hline Contexto & $\begin{array}{l}\text { llustra a } \\
\text { aplicação de um } \\
\text { conceito. }\end{array}$ & $\begin{array}{l}\text { Apresentado de } \\
\text { maneira escrita, mas } \\
\text { fazendo referência ao } \\
\text { mundo real, exige } \\
\text { raciocínio além da } \\
\text { aplicação de } \\
\text { conceitos. }\end{array}$ & $\begin{array}{l}\text { Simula situações } \\
\text { próximas à realidade } \\
\text { para testar a ação do } \\
\text { sujeito em ambiente } \\
\text { controlado. }\end{array}$ & $\begin{array}{l}\text { É essencial que seja real } \\
\text { para o desenvolvimento } \\
\text { e manifestação das } \\
\text { competências, sendo } \\
\text { significativo para o } \\
\text { sujeito e a comunidade. }\end{array}$ \\
\hline Autonomia & $\begin{array}{l}\text { Com as } \\
\text { informações } \\
\text { fornecidas o } \\
\text { sujeito é capaz } \\
\text { de apresentar } \\
\text { respostas aos } \\
\text { problemas } \\
\text { propostos. }\end{array}$ & $\begin{array}{l}\text { Permite que o sujeito } \\
\text { aprenda a buscar } \\
\text { informações em } \\
\text { materiais de modo a } \\
\text { aprender um conceito } \\
\text { ou procedimento com } \\
\text { auxílio do professor. }\end{array}$ & $\begin{array}{l}\text { O sujeito se propõe a } \\
\text { conhecer acerca de } \\
\text { determinado assunto } \\
\text { sendo capaz de } \\
\text { identificar problemas e } \\
\text { propor soluções sob } \\
\text { tutoria. }\end{array}$ & $\begin{array}{l}\text { Desenvolve no sujeito } \\
\text { capacidade de, de } \\
\text { forma, crítica, estudar } \\
\text { uma situação real, } \\
\text { propor uma solução e } \\
\text { executá-la de forma } \\
\text { eficaz em seu raio de } \\
\text { ação. }\end{array}$ \\
\hline Experimentação & $\begin{array}{l}\text { É importante } \\
\text { para confirmar } \\
\text { conceitos. Pode } \\
\text { servir como } \\
\text { contexto. }\end{array}$ & $\begin{array}{l}\text { Serve como } \\
\text { problematização para } \\
\text { que o sujeito levante } \\
\text { hipóteses, pesquise a } \\
\text { respeito e atinja o } \\
\text { conhecimento } \\
\text { esperado. }\end{array}$ & $\begin{array}{l}\text { Simula, de forma } \\
\text { controlada, situações } \\
\text { reais que em geral } \\
\text { fazem referência ao } \\
\text { mundo real exigindo } \\
\text { propostas de } \\
\text { resolução. }\end{array}$ & $\begin{array}{l}\text { É parte do processo de } \\
\text { resolução da situação, } \\
\text { que só é real pois dela e } \\
\text { nela se experimenta. }\end{array}$ \\
\hline O Mundo & $\begin{array}{l}\text { É preciso, a } \\
\text { partir da escola, } \\
\text { ensinar o sujeito } \\
\text { a ler o mundo. }\end{array}$ & $\begin{array}{l}\text { É preciso que, na } \\
\text { escola o sujeito } \\
\text { aprenda a ler o mundo. }\end{array}$ & $\begin{array}{l}\text { É preciso que, a partir } \\
\text { da escola, o sujeito } \\
\text { leia o mundo de forma } \\
\text { crítica. }\end{array}$ & $\begin{array}{l}\text { É preciso que com a } \\
\text { escola o sujeito leia e } \\
\text { intervenha no mundo de } \\
\text { forma crítica. }\end{array}$ \\
\hline Interdisciplinaridade & $\begin{array}{l}\text { Uma disciplina } \\
\text { pode referir-se a } \\
\text { outra ou tomar } \\
\text { conhecimentos } \\
\text { próprios de outra } \\
\text { disciplina na } \\
\text { resolução de } \\
\text { problemas } \\
\text { específicos. }\end{array}$ & $\begin{array}{l}\text { Pode-se integrar } \\
\text { disciplinas de } \\
\text { conhecimentos } \\
\text { próximos em } \\
\text { situações-problema } \\
\text { específicas que } \\
\text { contribuem para a } \\
\text { ampliação do } \\
\text { entendimento de um } \\
\text { conceito. }\end{array}$ & $\begin{array}{l}\text { As disciplinas podem } \\
\text { ser agrupadas em } \\
\text { áreas de } \\
\text { conhecimento que } \\
\text { tratam de temas e } \\
\text { situações afins. }\end{array}$ & $\begin{array}{l}\text { O mundo real e } \\
\text { essencialmente não } \\
\text { disciplinar, por isso esse } \\
\text { conceito faz pouco } \\
\text { sentido para o } \\
\text { desenvolvimento de } \\
\text { competências. }\end{array}$ \\
\hline Avaliação & $\begin{array}{l}\text { Apresentar, em } \\
\text { geral de forma }\end{array}$ & $\begin{array}{l}\text { Realizar tarefas, em } \\
\text { geral experimentais }\end{array}$ & $\begin{array}{l}\text { Atuação do sujeito em } \\
\text { projetos que simulam }\end{array}$ & $\begin{array}{l}\text { Solução eficaz e } \\
\text { socialmente aceita para }\end{array}$ \\
\hline
\end{tabular}


Quadro 6.2. - Classificação completa de perfil dos professores e professoras para as categorias definidas a partir das respostas ao questionário de pesquisa.

\begin{tabular}{|l|l|l|l|}
\hline Tradicional & $\begin{array}{l}\text { Tradicional } \\
\text { Renovado }\end{array}$ & $\begin{array}{l}\text { Competência } \\
\text { Institucional }\end{array}$ & Competência \\
\hline $\begin{array}{l}\text { escrita, } \\
\text { resolução de } \\
\text { problemas } \\
\text { aplicando } \\
\text { conceitos e } \\
\text { procedimentos } \\
\text { corretos. }\end{array}$ & $\begin{array}{l}\text { realizando } \\
\text { procedimentos de } \\
\text { maneira correta, além } \\
\text { de solucionar provas } \\
\text { escritas com questões } \\
\text { que podem ser } \\
\text { dissertativas ou que } \\
\text { exijam interpretações } \\
\text { mais avançadas. }\end{array}$ & $\begin{array}{l}\text { considerando o uso de } \\
\text { conceitos, } \\
\text { procedimentos e } \\
\text { atitudes ao longo da } \\
\text { produção. }\end{array}$ \\
\hline
\end{tabular}

Fonte: Elaborado pelo autor.

Em relação à visão dos professores sobre os elementos que indicam a ênfase de competências no processo de ensino-aprendizagem, apresentamos a seguir respostas que exemplificam cada um dos perfis sugeridos para classificar as categorias de competência, e para que a partir daí, seja possível fazer uma análise mais cuidadosa do conjunto de respostas.

Tendo em vista que desconsideramos aqui o fator relacionado ao curso realizado pelos sujeitos que responderam ao questionário, nos referiremos a eles apenas por um número, precedido pela letra "P", que indica apenas que estaremos apresentando o que escreveu o professor ou professora número 20 , indicado por P20, por exemplo. A seguir são apresentadas algumas respostas ao questionário que exemplificam cada perfil adotado.

Tradicional: Acredito que a ênfase seja dada a medida que o aluno reproduz os conhecimentos construídos. (P11)

Tradicional-Renovado: Atitude; isto é, o indivíduo adquire atitude de estudar. Ele não responde "mecanicamente", ele busca relacionar os conhecimentos as habilidades das áreas para tentar resolver uma situação problema. (P43)

de Competência-Institucional: A ação relacionada à aprendizagem, mobilizando diferentes recursos, sejam próprios ou aprendidos na escola. (P17)

de Competência: Seria um ensino que visa uma formação para a vida, em que a sua formação permita tomar decisões de acordo com o momento. (P47) 
Considerando a classificação proposta na tabela observou-se que cerca de $67 \%$ das respostas a esta questão se enquadraram no perfil Tradicional ou Tradicional -Renovado enquanto os outros 33\% puderam ser classificados entre os de Competência-Institucional ou de Competência. Esse resultado contrasta com as respostas dadas à questão sobre os objetivos do ensino tradicional e do ensino por competências, em que $87 \%$ dos professores e professoras responderam negativamente, que os objetivos dos dois modelos de ensino não são os mesmos.

É importante frisar que não pudemos classificar algumas respostas por serem muito curtas e por isso não apresentaram informações suficientes, ou apesar de não serem respostas curtas, não pudemos compreender 0 argumento apresentado para atribuir-Ihe uma classificação. Essa situação pode ser observada em "Desenvolver habilidades para chegar às competências" (P65).

\subsection{Considerações acerca das visões dos professores e professoras}

Agora, considerando o quadro 2 de perfis como critério de classificação, retomaremos a análise a respeito de algumas categorias que se destacaram nas respostas por sua constante ocorrência e por sua relevância para o entendimento das competências.

\subsubsection{Em que consiste o ensino por competências?}

Termos anteriormente apresentados neste trabalho tiveram uma presença importante nas respostas. A ideia de interdisciplinaridade ou de prover aos estudantes situações ou problemas interdisciplinares apareceu em ao menos 5 respostas. A autonomia ou pensamento crítico, foi também citada, aparecendo em 6 respostas. A ideia de contexto embora tenha aparecido nas respostas, precisa ser encarada com cuidado. Algumas respostas relacionaram diretamente o contexto com a realidade, com situações que fazem parte do cotidiano do aluno, outras apenas citam a palavra, de modo que não podemos ter certeza se o contexto a que se refere tal resposta pretende resgatar problemas que fazem parte do cotidiano imediato do estudante, e que portanto 
será para ele um problema real que exigirá uma resposta real, ou se a ideia de contexto apresentada dá conta apenas de uma aplicação para determinados conhecimentos, mesmo que não haja relação com o cotidiano do estudante, ou com a realidade. Um exemplo são questões de vestibulares que utilizam histórias em quadrinhos para contextualizar a apresentação de um enunciado, mas que não necessariamente tem relação com a realidade.

Destacaram-se duas ideias nas respostas apresentadas. A primeira foi o uso de experimentação como elemento que indica o trabalho por competência, sendo verificado em ao menos 13 respostas. Em alguns casos as respostas indicavam que o uso da experimentação deveria privilegiar o trabalho investigativo do estudante como em "realizar atividades onde os alunos podem coletar dados através de observações para ao final do processo o aluno possa elaborar conclusões" (P12). Ou em: "Utilização de experimentos onde o aluno tem que ser um pesquisador e não apenas um seguidor de roteiro" (P22). Nesses dois exemplos os professores sugerem que os estudantes devem ser mais ativos no processo de ensino-aprendizagem de modo a desenvolver suas competências.

Como apresentado no capítulo 2, as competências para Perrenoud, Jonnaert e Zabala possuem dimensões complexas de saberes que se pode resumir como: saber, saber fazer e saber ser. De acordo com esses autores, o desenvolvimento de competências se dá quando esses saberes são mobilizados para apresentar uma resposta eficaz em situação ${ }^{32}$. Com base nessa estrutura verificou-se que muitas respostas ao questionário enfatizaram o desenvolvimento de saberes conceituais, para os quais os saberes procedimentais (como a experimentação), deveriam ser um apoio, um dos fatores para o grande número de respostas classificadas como Tradicional ou Tradicional-Renovado. Verificou-se em ao menos 22 respostas uma indicação de que os professores e professoras relacionaram um ensino por competências com um desenvolvimento da capacidade cognitiva ou da assimilação de conceitos por parte dos estudantes.

32 Veja Capítulo 3 para maiores detalhes sobre as definições de competências nos quatro autores citados. 
Competência cognitiva, capacidade de aprendizagem o qual estão relacionados com o rendimento escolar (P5)

Desenvolvimento cognitivo do aluno considerando sua leitura do mundo (P8)

Pensar, aprender, autonomia, senso crítico (P9)

A interpretação do enunciado, compreender e elaborar relações das Leis da Física (P34)

A não utilização apenas de problemas de resolução de contas, exercícios de caráter objetivo apenas (P36)

Atitude; isto é, o indivíduo adquire atitude de estudar. Ele não responde "mecanicamente", ele busca relacionar os conhecimentos as habilidades das áreas para tentar resolver uma situação problema. (P44)

A resolução de problemas usando os conteúdos aprendidos na sala de aula. (P50)

Os exemplos de resposta selecionados permitem compreender que os professores e professoras que responderam ao questionário, preocupam-se em que os estudantes possam alcançar um novo patamar cognitivo abandonando reproduções mecânicas de respostas esperadas.

Dessa forma os saberes cognitivos ou conceituais devem ser enfatizados, e para isso, os saberes procedimentais devem dar suporte. Não é claro como os saberes atitudinais podem ser evidenciados, a não ser que a atitude a que se refere esteja relacionada com o desenvolvimento de saberes conceituais, como adquirir "a atitude de estudar".

6.3.2. Sobre os objetivos do ensino tradicional e por competências

Das respostas analisadas 8 foram positivas, em que os objetivos do ensino tradicional é o mesmo do ensino por competências, uma argumentou que depende do direcionamento aplicado pelo professor e 57 pessoas disseram que não, os objetivos do ensino tradicional e do ensino por competências não seriam os mesmos.

A seguir são apresentadas as respostas positivas à questão 
Os objetivos são os mesmos, porém os processos, procedimentos e as demandas para os professores, alunos, pais e gestão escolar são diferentes como, por exemplo, a interdisciplinaridade. (P17)

De certa forma SIM, pois em ambos busca-se desenvolver determinado conteúdo. No entanto, no ensino tradicional o conteúdo é um fim em si mesmo, já no ensino por competências, se busca atingir o conteúdo por meio do desenvolvimento de competências e habilidades (P22)

Entendo que alguns objetivos de um ensino tradicional estejam inseridos no ensino por competências (P.E. resolução de exercícios). (P31)

Sim, serve como parâmetro (P32)

Se for para formar um cidadão crítico sim, mas depende muito se o aluno atingiu as habilidades necessárias para sua competência (P34)

Teoricamente sim, espera que os alunos atinjam tal (P36)

Acredito que sim (P54)

Sim, pois para que se alcance o ensino tradicional o aluno precisa ser competente para tal, ou seja, as competências estão inseridas no processo (P56)

Algumas respostas, como as dadas por P36 e P54, possuem poucas informações sobre a posição do professor ou professora, e por isso torna-se muito difícil analisá-las ou mesmo classificá-las. Mas nas outras respostas, é interessante notar uma tendência a se encarar as competências como um meio para que se atinjam os objetivos estipulados pelo ensino tradicional. As competências parecem assumir, portanto, um caráter de metodologia a serviço dos objetivos estipulados desde o ensino tradicional.

De outro lado, os professores e professoras que entendem que 0 ensino por competência e o ensino tradicional não possuem o mesmo objetivo apresentaram argumentação parecida. A tensão apresentada é entre a ênfase em um objetivo mais amplo, algumas vezes relacionado à sociedade, e um aprendizado descontextualizado, memorístico e que tem fim em si mesmo. A seguir são apresentadas algumas respostas.

NÃO, pois o ensino tradicional está baseado no conteúdo, como se o aluno tivesse que "absorver" toda informação, sem necessidade de desenvolver/trabalhar as competências que estes alunos possuem. $O$ 
ensino por competência buscam desenvolver consciência e trabalhar/organizar suas ideias. (P1)

Acho que o Ensino de Competências nos dá uma oportunidade de discutir um ensino de química mais reflexivo e que discuta uma abordagem social do ensino. (P3)

NÃO. O ensino tradicional preconiza mera memorização, enquanto o ensino por competências prioriza processos cognitivos. (P10)

Não, no ensino tradicional temos a "aula bancária" onde há depósito de conteúdos sem a responsabilidade de desenvolver um aluno com competências cognitivas. (P13)

Não, o ensino tradicional não é levado em consideração a competência você padroniza as aptidões. (P42)

Não, o ensino tradicional é conteudista e o por competências vai aguçando valores e habilidades ao conhecimento do aluno. (P58)

Não, geralmente o ensino tradicional foca os conteúdos a fim da capacitação do aluno para o vestibular. (RP64)

É marcante a relação feita pelos professores entre aquilo que se entende por ensino tradicional e a ênfase nos conteúdos ou a um ensino conteudista, enquanto que um ensino por competências, mesmo que de uma maneira mais dispersa não seja relacionado a elementos específicos, parecem representar o que se opõe ao ensino tradicional. Essa questão será analisada mais detidamente adiante.

\subsubsection{Sobre o contato em formação com o conceito de competência}

Apesar de os professores possuírem algum conhecimento acerca do conceito de competências, esse fato não necessariamente indica a presença das competências na sua prática. Isso pode se dever a diversos fatores, e era o que se procurava compreender na seção III do questionário. Tendo em vista o perfil dos professores e o quadro de classificação apresentados na seção 4.2 são apresentados a seguir alguns resultados obtidos a partir das respostas ao questionário, sobre a prática e o contato dos professores e professoras em relação ao conceito de competências. 
Com relação ao contato anterior dos professores e professoras com o conceito de competência, 33 haviam tido contato com esse conceito na escola em que trabalharam, 22 adotaram livro didático que tratava de competências, 40 tiveram esse contato por meio de outros materiais utilizados em sala, 8 pessoas nunca haviam tido contato com esse conceito e 7 tiveram esse contato por meio de outras fontes como leitura de artigos, estudo do currículo ou realização de cursos.

A partir dos dados coletados com o questionário, não é possível entender qual foi a abordagem para as competências dada nos materiais, cursos ou formações recebidas. Mas é interessante notar que as competências, de alguma forma, parecem ser discutidas no ambiente escolar. Os professores e professoras têm tido contato com esse conceito, grande parte no ambiente escolar, e podem até sentir a cobrança de desenvolver as competências em aula.

6.3.4. Elementos da prática docente relacionados às competências

Aqui foram abordados aspectos que influenciam na prática docente no que diz respeito à adoção das competências. Se a instituição encoraja o trabalho por competências, se é dada a orientação para este tipo de abordagem, o que contribui e o que é empecilho para essa prática. Entendemos que esses elementos, além do que é prescrito nos documentos oficiais, e talvez de maneira mais intensa, são de grande influência na adoção ou rejeição das competências na prática dos professores e professoras.

Com relação ao trabalho por competências, muitos professores haviam conduzido atividades que apontavam ou consideravam este conceito, mas destes, alguns apontaram que o trabalho não se desenvolveu da forma como gostariam.

Sim, mas de forma precária. (P22)

As vezes, nem sempre a escola trabalha nessa direção. (P9)

Alguns professores e professoras são cobrados pela escola para que desenvolvam um trabalho com base em competências, mas não 
necessariamente fornecem os recursos necessários para isso, dessa forma é o professor e a professora que desenvolve suas próprias pesquisas sobre 0 assunto e tenta desenvolver o trabalho por competências. Outros professores e professoras procuram trabalhar com esse conceito a despeito das dificuldades enfrentadas, sobretudo quando a escola não enfatiza esse desenvolvimento.

Trabalho com sistemas de ensino e fico muito preza. As escolas que trabalhei nem sempre direcionam os trabalhos neste sentido. Nunca recebi orientações para isso é a primeira vez. (P6)

As escolas onde atuei não sinalizavam com eficiência para o trabalho por competências. Era e ainda são falhas. Poucas orientações verbais, apenas por leitura própria em recursos didáticos. (P11)

Já houve tentativa, mas o tempo necessário para planejar essa atividade nunca foi disponibilizado para os docentes. (P12)

Nas escolas há um discurso sobre a importância das competências, porém exigem do professor, mas não o auxiliam em como fazer isso. (P23)

$\mathrm{Na}$ escola onde atuo [...] existe uma preocupação e um engajamento do corpo docente, com discussões e trocas de experiências. (P31)

De certa maneira sim, pois os documentos de referência trabalham com competência mas isso também não significa o entendimento pleno sobre e nem que as aulas realmente sejam dessa natureza. (P35)

É interessante notar na resposta de P35 que se reconhece a orientação dos documentos oficiais. Se as Diretrizes, Parâmetros, Base e o Currículo falam a respeito das competências então de alguma maneira os processo de ensino-aprendizagem está subordinado a essa fala. Contudo, aponta uma distância entre o discurso dos documentos e a efetiva aplicação desse discurso em sala de aula, pois o "entendimento" do que se quer dizer com competências, pode não estar claro.

Alguns professores receberam orientação regular a respeito do trabalho por competências, como na resposta de P31, mas o que parece se repetir bastante, é que a orientação efetiva para o trabalho é precária, enquanto a exigência ou pelo menos um discurso da necessidade de se trabalhar por competências está presente, como na fala de P23. 
Sobre aquilo que contribuiria e aquilo que é um empecilho para o trabalho por competências, as respostas obtidas foram parecidas, afirmando ou negando elementos comuns. A necessidade de formação e orientação sobre competências foi bastante apontada como fator de contribuição, ao passo que a ausência desses treinamentos foi apontado como um fator de empecilho. Outros elementos apontados como empecilho para o trabalho por competências são: a falta de recurso, como materiais e tempo necessário para planejamento, necessidade de cumprir conteúdos rígidos, sobretudo quando o professor ou professora precisa seguir algum tipo de material apostilado, e falta de interesse dos próprios estudantes.

Trabalho com sistema apostilado, o que induz ao ensino tradicional. (P37)

No meu entendimento temos diversos problemas uma delas seria a falta de recursos didáticos e também a formação da gestão e docentes. (P51)

Seria necessário uma formação neste caso. (P54)

A dificuldade está nos modelos gestores tradicionais. (P55)

A dificuldade é que o aluno muitas vezes não se interessa igual por todas as matérias. (P58)

O que dificulta falta de material. (P63).

\subsection{Elementos de competências e a oposição ao ensino tradicional}

Com base no perfil apresentado pelos professores, na classificação das respostas com base na tabela 4.1 e na análise de algumas respostas é possível fazer algumas inferências sobre a relação dos professores e professoras com o conceito de competência ou de maneira mais ampla com um ensino por competências.

É possível perceber que diversos termos observados nos textos teóricos sobre competências aparecem nas respostas dos professores e professoras, o que não indica necessariamente que o entendimento a respeito desses termos é completo ou que esteja em acordo com aquilo que os teóricos propuseram, mas mostra que existe algum fluxo de informação entre os 
desenvolvimentos teórico e prático das competências. Esse fluxo é intermediado por documentos oficiais, pelos currículos e materiais didáticos. Mas é a assimilação dos professores, sua visão, sua situação de trabalho e as exigências a que devem atender que determinam como as competências serão trabalhadas no processo de ensino-aprendizagem.

Termos como aprender a aprender e contexto, são apresentados nos documentos oficiais. No caso do termo "experimentação" que foi bastante recorrente nas respostas coletadas, é importante relembrar que os professores e professoras que responderam ao questionário eram de áreas relacionadas às ciências, e portanto, o uso da experimentação faz parte de sua formação, e possivelmente de sua prática. Contudo, o uso de experimentação no ensino de ciências não necessariamente está relacionado a um ensino por competências. Escolas que adotam um ensino tradicional muitas vezes possuem laboratórios de ciências extremamente modernos e completos. Escolas técnicas ou materiais tecnicistas podem dar indicações e realizar experimentos de maneira bastante profusa, portanto, o simples uso da experimentação não necessariamente caracteriza um ensino por competências. A experimentação é uma metodologia que pode ser explorada em diversos tipos de currículo, assim como a leitura, a pesquisa, a redação ou a realização de operações matemáticas.

Algumas respostas dos professores colocam a experimentação como um apoio ao desenvolvimento cognitivo, podendo ser encarada como uma espécie de motivador ou como meio de confirmação de um conceito. Mas outros exemplos colocam o aluno e a aluna como protagonistas de sua própria aprendizagem, pois eles não devem seguir roteiros prontos (como em geral se espera que aconteça em sistemas de ensino mais tradicionais ou tecnicistas) e devem ter uma atitude científica de investigação. Considerar esse maior protagonismo dos estudantes realmente aproxima 0 ensino do desenvolvimento de competências, uma vez que requer um maior desenvolvimento de sua autonomia, mas não é capaz de, sozinho, indicar de fato o uso das competências. E isso se dá em grande parte por conta do objetivo ou do cidadão e cidadã que se busca formar com o uso da experimentação. 
Também em relação aos saberes, fica clara a preocupação dos professores e professoras com relação ao desenvolvimento dos saberes dos estudantes. Contudo, na visão de grande parte dos respondentes, esse desenvolvimento ainda é cognitivo. Os sujeitos no processo de ensinoaprendizagem devem, portanto estar preparados para questões de maior complexidade, que exijam raciocínio mais elaborado. Mas percebe-se que a ênfase parece estar em que os alunos e alunas sejam capazes de responder às demandas que a própria escola ou o sistema educacional Ihes colocará. Se a visão dos professores a respeito de competências tem sido formada pelo uso das competências na resolução de provas objetivas como o ENEM, faz sentido que os estudantes precisem aprimorar sua capacidade de "interpretar enunciados" ou até mesmo evitar "responder mecanicamente" a determinadas questões, dada a natureza das questões do ENEM. Dessa forma algumas respostas classificadas como Tradicional-Renovada, podem estar revelando uma tentativa de adequação a exigências dos exames em lugar de uma real assimilação das competências.

São reveladas, portanto, contradições e talvez confusões com relação aquilo que se entende por ensino tradicional, por competências e os objetivos e elementos relacionados a estes modelos de ensino. Com relação à questão $B$ da primeira seção outras duas respostas que chamam atenção são as dadas por P34 e P56.

Se for para formar um cidadão crítico sim, mas depende muito se o aluno atingiu as habilidades necessárias para sua competência. (P34)

Sim, pois para que se alcance o ensino tradicional o aluno precisa ser competente para tal, ou seja, as competências estão inseridas no processo. (P56)

Nesses casos os professores ou professoras entendem que o objetivo é dado desde o ensino tradicional, mas para que o estudante atinja os objetivos propostos, ele ou ela deve ser uma pessoa competente ou as habilidades da competência precisam ser "atingidas". Dessa forma, parece ser necessário haver uma listagem de habilidades e competências que devem ser atingidas ou desenvolvidas pelos estudantes, o que de acordo com Jonnaert et al. (2010) causa um embaraço, pois as competências devem se desenvolver em 
situação, portanto uma listagem fechada de competências se aproximaria de uma listagem fechada de objetivos ou conteúdos que é característica do ensino tradicional. Esse argumento aproxima as competências da noção de desempenho trabalhada por Jonnaert ${ }^{33}$. Tal posicionamento pode ser reforçado pelo fato dos exames oficiais possuírem uma matriz de competências e habilidades, segundo a qual os estudantes serão classificados e que ajuda na elaboração de cursos e materiais didáticos.

Outro dado é que, embora a prova do ENEM seja organizada em sessões de Linguagens, Ciências Humanas, Ciências da Natureza e Matemática, existe uma razoável facilidade na classificação das questões por disciplina correspondente. Ou seja, na prova de Ciências da Natureza, por exemplo, é possível diferenciar questões de Física das questões de Química ou Biologia (com raras exceções em que a questão pode ser classificada em duas disciplinas ou em nenhuma delas especificamente), e isso é feito identificando-se os conteúdos de que trata cada questão (PAIVA, 2014). Portanto, parece haver uma confusão entre o desenvolvimento de competências e a melhoria do desempenho dos estudantes em situação de exame, confusão que pode ser reforçada pelos textos dos documentos e pela estrutura dos exames oficiais.

A ênfase das respostas apresentadas como exemplo, de muitas outras que não foram apresentadas, é a de que o ensino tradicional é mais voltado para a transmissão de conteúdo enquanto o ensino por competências é relacionado a um ensino mais reflexivo, que tem impactos na sociedade $\mathrm{e}$ permite a resolução de problemas. Destaca-se a resposta de P13 "não, no ensino tradicional temos a 'aula bancária' onde há depósito de conteúdos sem a responsabilidade de desenvolver um aluno com competências cognitivas" que faz referência ao conceito de educação bancária trabalhada em Freire (1996).

Embora essa associação seja comum, precisam ser tomadas com cuidado. Os críticos das competências por vezes acusam certa negligência em relação aos conteúdos disciplinares em favor dos processos. É importante destacar que, como discutido no capítulo 2 , nenhum dos autores apresentados

\footnotetext{
${ }^{33}$ Essa noção de desempenho é apresentada no Capítulo 2.
} 
defende a abolição dos conteúdos ou das disciplinas, ao contrário, atribuem a eles papel importantíssimo no desenvolvimento das competências. Contudo é discutida a abordagem e relevância do conteúdo abordado, assim como a tentação de acreditar que absorver e replicar determinado conteúdo, fora de situação, é suficiente para formar uma pessoa plena.

Outro ponto importante a destacar é que Zabala e Arnau (2010) chamam a atenção para o perigo de uma associação tão polarizada entre o Ensino Tradicional e o Ensino por Competências. Embora existam metodologias, como a aula expositiva, que são características de um ensino tradicional e mecanizado devido ao seu uso quase que monotônico, essas metodologias, assim como os conteúdos disciplinares, não devem ser abandonadas, mas devem ter seu valor resignificado, pois podem ser úteis para situações ou estudantes de perfil específico. 


\section{OS SENTIDOS DE COMPETÊNCIAS}

Ao longo deste trabalho, foi possível verificar diferentes sentidos assumidos pelo conceito de competências em diferentes níveis de discussão. Por vezes, dentro de um mesmo nível, é possível verificar sentidos diversos em âmbitos ou autores distintos.

No nível teórico as competências podem ser desenvolvidas em diferentes campos de conhecimento. Dos linguistas ao mundo do trabalho e à educação. Concentrando nossa investigação do campo da educação, mas sem ignorar o uso do conceito em outros campos, foi possível constatar que apenas nessa área de conhecimento, as competências podem assumir diversos sentidos e definições. Reconhecemos, no entanto, que existem diversas outras linhas e abordagens, que podem inclusive apresentar maior divergência em relação àquelas aqui discutidas, e que podem ser aprofundadas em uma investigação mais específica.

Nos autores apresentados, contudo, foi possível perceber alguma diferença de abordagem, embora características mais gerais possam ser verificadas em todos eles. 
Algumas dessas características puderam ser identificadas na investigação de outros níveis hierárquicos no sistema de ensino. Competência, Autonomia e Interdisciplinaridade são elementos relacionados ao desenvolvimento teórico das competências, mas que aparecem novamente ao longo de toda a investigação.

\subsection{Os sentidos de competências e suas transformações}

Ao se analisar os sentidos atribuídos às competências nos diferentes âmbitos e níveis em que o conceito é utilizado, nosso entendimento é o de que as competências assumem sentidos distintos. Por esta razão, para debates mais frutíferos, é preciso clareza a respeito do contexto no qual o conceito esta inserido.

Os teóricos apresentam as competências como uma ferramenta de organização de ensino, como alternativa a um ensino tradicional e desconectado da realidade. Nesse nível de discussão as competências possuem um caráter bastante amplo. Em princípio, estes teóricos não descrevem, necessariamente, as competências, na maneira como devem ser tratadas no ambiente escolar. Sua visão, embora concentrada na educação, é de sociedade. Os autores reconhecem a importância de uma reestruturação escolar para que o desenvolvimento das competências possa permitir a formação de jovens mais preparados para a vida adulta, considerando as características específicas de nossa sociedade. Os teóricos, não se apresentam contra as disciplinas, mas criticam uma visão puramente disciplinar, mencionam a junção de algumas das disciplinas clássicas ou o surgimento de outras disciplinas mais adequadas ao tratamento de situações cotidianas, mas não pretendem estabelecer critérios, estruturas, receitas ou programas sobre como trabalhar com essas disciplinas a partir de uma lógica de competências. De acordo com a perspectiva de Perrenoud (2012), uma estruturação deste tipo seria impossível ou sem sentido para esse nível da discussão.

Se houvesse uma conceitualização científica única das competências, poderíamos tentar compará-la de forma metódica, com as definições utilizadas nos programas escolares que pretendem fazer com que elas constituam os principais objetivos da 
educação básica. Infelizmente, essa referência a uma teoria consensual não é possível e, mesmo que fosse, não teria nenhuma legitimidades específica. (PERRENOUD, 2012, p. 41).

Uma das razões para a impossibilidade apresentada por Perrenoud, é que teorias educacionais (assim como outras) não precisam restringir-se ao país ou região em que foi desenvolvida. Teorias educacionais russas, americanas, brasileiras ou francesas espalham-se por todo o mundo, contudo as especificidades locais e circunstanciais precisam ser consideradas quando da adoção de uma determinada teoria. Sobre isso Perrenoud ainda afirma que:

Os conceitos que organizam a educação estão sempre ligados a uma história e a uma cultura nacional, as quais, por sua vez, fazem parte de um espaço linguístico em que as palavras utilizadas para dar nome à ação educativa, às aprendizagens e aos objetivos não tem, precisamente, o mesmo sentido em outros espaços linguísticos. As noções de competência, de habilidade, de aptidão, de capacidade e de faculdade mental são difíceis de serem traduzidas com exatidão. (PERRENOUD, 2013, p.40).

Dessa forma, quando a discussão sobre competências passa para o nível de documentação oficial, podemos perceber a mudança nos sentidos atribuídos as competências, o que, de acordo com Perrenoud, é esperado. A LDB/96 introduz, na educação brasileira, a ideia de competência, possibilitando um pensar educacional que fosse além da listagem de conteúdo, ou seja, que permitia alguma contraposição à estrutura educacional anterior. Contudo, o tratamento dado às competências pela LDB/96 é ainda muito amplo.

O uso do conceito fica muito mais evidente nas DCN e nos PCN. A amplitude do sentido atribuído às competências pelos teóricos aparece mais restringido nas DCN que especificam espaço e tempo de ensino, oferecimento, estrutura de níveis e categorias de ensino. Uma restrição um pouco maior é observada no desenvolvimento dos PCN que adotam as terminologias de competências, mas as organiza de maneira ainda disciplinar clássica, isto é, as disciplinas que apareciam anteriormente no currículo brasileiro ainda eram apresentadas nos PCN e novas disciplinas não foram apresentadas.

É verdade que se pretende uma maior ampliação dos sentidos das competências a partir da proposta em discussão para a BNCC, que não se organiza por disciplinas, mas sim por áreas de conhecimento. Contudo, mesmo 
essa especificação do conhecimento por áreas, que na BNCC ainda não é final, apresenta uma maior restrição com relação à visão dos teóricos.

O próximo passo é a organização dos conteúdos que se dá nos livros didáticos, com base no que é estipulado nos documentos curriculares. Embora o sentido das competências nos documentos seja menos amplo do que nos teóricos, estes documentos são válidos para todo o território nacional o que contribuí para uma considerável amplitude do sentido que o documento atribui às competências. Mas é no nível do livro didático que o número de bifurcações aumenta consideravelmente e assim a restrição imposta ao conceito. Cada autor atribuirá, de acordo com o seu entendimento, um sentido às competências. Considerando a visão dos teóricos de apresentar as competências como alternativas ao ensino tradicional, é possível perceber em algumas obras um movimento de tentativa de renovação, propondo não só uma discussão mais aprofundada das competências, mas metodologias e sequências que possibilitem um trabalho mais adequado nesse sentido. Em outros casos, as competências são apenas listadas como os novos objetivos do sistema educacional vigente, mas que não necessitam de grande atenção, pois é a estruturação e linearidade dos conteúdos que importam para o ensino de qualidade. Nesse sentido, as competências perdem a característica de alternativa ao ensino tradicional e se fundem a ele. É importante frisar que a própria noção de um livro didático que ajuda a nortear um curso de Física por exemplo, por mais alinhado que esteja com a proposta de ensino por competências, restringe em muito a visão dos teóricos para que quem as situações deveriam partir da realidade e então serem resolvidas, não apresentadas a partir de um manual que dificilmente considera as especificidades de todas as unidades escolares, sobretudo em um país com as dimensões e diversidades brasileiras.

Mas é na sala de aula que o conceito de competência deve mostrar-se. Nas respostas ao questionário, apresentadas no capítulo 6, é possível perceber professores ou professoras que, em poucos casos tem contato com os autores teóricos das competências, por meio de um curso ou palestra específica. Como discutido anteriormente, a existência desses cursos mostram a presença de algum nível de discussão sobre competências nas escolas, mas na perspectiva 
aqui apresentada, é importante notar que o sentido das competências deve ter sofrido alterações até chegar neste nível de formação.

Também de acordo com as respostas ao questionário, e considerando a estrutura geral do ensino brasileiro, o contato do professor ou professora é mais direto com o livro didático, em que o sentido dado ao conceito de competência também sofreu muitas alterações em comparação com o seu desenvolvimento teórico. Além disso, o professor ou professora, caso elabore seu plano de aula a partir do livro didático, precisará utilizar o seu próprio entendimento e atribuir um sentido próprio às competências e à maneira como devem ser trabalhadas.

Cada um dos níveis anteriores apresentava uma maior restrição à amplitude dada às competências pelos teóricos devido às contingências, estruturas e restrições com as quais precisa lidar. Os professores e professoras representam, o nível em que essas contingências exigem maior grau de adaptação. Os docentes precisam considerar a cultura escolar na qual estão inseridos, o número de estudantes em sala, os prazos, a necessidade de avaliar as competências, muitas vezes exigindo-se que se faça isso por meio de provas e simulados. É compreensível, portanto, que se adapte os sentidos dados às competências e dessa forma, diversos entendimentos são atribuídos ao conceito, como foi possível constatar no capítulo 6 .

De maneira geral, foi possível constatar um movimento "antitradicionalista" (no que diz respeito ao modelo de ensino) por parte dos professores e professoras que responderam ao questionário. Muitos docentes reconhecem o valor das competências e parecem querer adotar este conceito em sua prática. Por vezes, eles e elas atribuem à adoção de determinada atividade a resposta para 0 uso das competências, mesmo que involuntariamente reproduzindo lógicas ainda alinhadas com um ensino de característica mais tradicional, resultando nas mais diversas visões a respeito das competências ou das práticas a elas relacionadas a elas.

Um último nível não explorado neste trabalho, mas que pode ser uma interessante linha de investigação é compreender o sentido com que as competências são absorvidas pelos estudantes. Estudantes formados no ensino médio conseguem fazer uma boa caracterização da escola com base 
em disciplinas. Devem conseguir diferenciar quais conteúdos estão no domínio da química ou da filosofia, em geral conseguem julgar se aprenderam ou não determinado conteúdo, mas seriam os estudantes capazes de diferenciar competências aprendidas? Seriam capazes de reconhecer, no cotidiano 'adulto', quando utilizam uma competência desenvolvida na escola? Essa percepção dependeria dos sentidos que os próprios estudantes atribuem às competências?

\subsection{A avaliação de competências}

A avaliação em um sistema baseado em competências também precisa ser discutida, sobretudo no que diz respeito aos sentidos das competências que se deseja avaliar.

De acordo com o que foi discutido no início deste capítulo, uma competência se manifesta muito mais no processo do que no resultado apresentado a uma situação, dependendo do sentido que se the atribui. Se forem os sentidos discutidos pelos teóricos então a análise do processo toma muito mais valor, mas quando as competências são estruturadas como objetos curriculares, é a resposta eficaz que tem maior peso.

É preciso pensar em como exames padronizados como o ENEM podem ser capazes de inferir o desenvolvimento de competências, dado que não consideram o processo, mas apenas a resposta eficaz. Considerando a BNCC, com a parte comum e a parte diversificada, como deve se reorganizar o ENEM? O exame levará em conta também as especificidades de cada região brasileira?

A relação com as competências de elementos como autonomia, aprender a aprender, ação na sociedade e outros indica que elas devem ser importantes para a vida do sujeito.

Pode ser que essa importância seja restrita a vida profissional, ou mais ampla, no sentido de formação para a cidadania, mas um dos pontos centrais é que o sujeito deve ter a capacidade de tomada de decisão. Compreender uma situação, discernir o problema enfrentado, considerar impactos e tomar uma decisão, parece ser um processo comum no que diz respeito ao ensino de competências. 
O ENEM se propõe desde sua criação a avaliar essas competências. $O$ exame presente ser uma "prova de raciocínio" com itens que levam o aluno a "tomadas de decisão". Contudo, como foi discutido no capítulo 5 , embora 0 discurso do ENEM seja baseado em grande parte no desenvolvimento dos teóricos das competências, a aplicação do exame nem sempre se aproximam deste ideal. Com a homologação da BNCC desde o Berçário até o Ensino Fundamental II e com a sua iminente aprovação definitiva para o Ensino Médio, a necessidade de se estabelecer como acontecerá a avaliação das competências ali estabelecidas se torna evidente. Não só a avaliação, mas, sobretudo o ensino de acordo com uma lógica de competências deve ser trabalhado.

\subsection{O ensino de competências}

Grande parte dos professores em atividade hoje em dia, foi formada segundo uma lógica disciplinar. A ideia de professor especialista não só estrutura o ensino nas escolas, como dá nome e estrutura os cursos de formação.

Como a pesquisa detalhada no capítulo 6 revela, poucos dos professores entrevistados tiveram orientação específica a respeito das competências, muitos têm conhecimentos a respeito desse conceito por conta de sua própria pesquisa. Muitas vezes as escolas abrem espaço para discussão e formação nesse sentido, mas sua estrutura continua de acordo com uma lógica disciplinar, dando aos professores poucos recursos, ou mesmo pouco tempo, para desenvolver um trabalho por competências.

A elaboração de projetos que sejam interdisciplinares, simulem a realidade e sejam capazes de promover o desenvolvimento e avaliação dessas competências, demanda dos professores, tempo investido em pesquisa e preparação, individual e conjunta, mas sobretudo uma mentalidade integrada que permita o desenvolvimento e avaliação dessas competências.

Não basta impor aos professores a necessidade de trabalhar as competências. Muitas vezes, inclusive pelo tempo escasso, os professores buscam orientação nas fontes mais práticas. Um exemplo seriam os manuais didáticos, que como discutido no capítulo 5 podem até apresentar as definições 
e o que se espera do trabalho por competência de acordo com o encontrado nas leis e textos oficiais. Mas muitas vezes, esses mesmos manuais didáticos não incorporam em seu texto o pensar por competências. Na prática, citam as competências quase que por uma necessidade protocolar, sem alterar sua estrutura organizacional, com índices estruturados como os dos materiais da década de 1980 ou anteriores ${ }^{34}$.

Outra fonte de informação para professores e escola pode ser o próprio ENEM. Por se tratar de um importante exame em âmbito nacional, e que pode significar para os jovens o ingresso em uma universidade pública, a atenção de escolas, cursinhos e materiais didáticos volta-se para como essa prova se organiza e aquilo que é "cobrado". Da mesma forma que os materiais didáticos, - ENEM possui um discurso teórico-metedológico de competências, que nem sempre se verifica na execução do exame. Provas padronizadas, apenas com itens de múltipla escolha e que por vezes exigem simples aplicações de fórmulas causam confusão com relação aquilo que se entende por competência.

O resultado da pesquisa realizada com os professores e professoras, mostrou que grande parte dessas pessoas, ao mesmo tempo em que veem as competências como algo que promoverá maior autonomia e pensamento crítico dos estudantes e acham que seria importante o desenvolvimento de trabalhos por competência, concentram, em sua visão sobre esse conceito, o desenvolvimento cognitivo.

Capacidade de raciocinar, de relacionar leis e teorias, de interpretar textos, de resolver diferentes tipos de exercícios, são algumas características desenvolvidas por um aluno competente, de acordo com os entrevistados. Existe uma evidente ênfase nos saberes conceituais e nas capacidades cognitivas dos estudantes, enquanto que enfrentar situações que simulem realidade, tomar decisões éticas, trabalhar em grupo, considerar ações que impactem a sociedade, são menos citadas.

${ }^{34}$ O manual do Projeto de Ensino de Física (PEF) de 1980 pode ser consultado em http://fep.if.usp.br/ profis/projetos/PEF/PEF Guia.pdf onde se percebe que a organização de conteúdos para o curso de Física é bastante parecida com a estrutura de grande parte dos materiais didáticos disponíveis no mercado editorial atual. 
Essa ênfase nas capacidades cognitivas dos estudantes e na realização de processos direcionados à resolução de problemas escolares, parece um reflexo da estrutura apresentada no ENEM e nos manuais didáticos. Ou seja, embora o discurso a respeito das competências leve em consideração o pensamento crítico, na prática, o pensamento crítico do estudante parece se limitar à resolução de um tipo específico de exercícios de múltipla escolha. Nenhuma pessoa entrevistada, por exemplo, citou a possibilidade de os estudantes promoverem ações de melhoria em seus bairros, ou mesmo de saberem como funcionam os canais de exigência para que o poder público 0 faça, ou mesmo identificar esses problemas em situações reais e não em um enunciado específico ou em uma atividade de laboratório. 


\section{CONSIDERAÇÕES FINAIS}

Ao longo dessa investigação, foi possível perceber a complexidade de nosso objetivo inicial, na medida em que mais e diversificadas dimensões e sentidos para as competências foram sendo identificados.

Por isso mesmo, os resultados obtidos podem ser considerados como preliminares, sinalizando algumas questões importantes a serem aprofundadas. Ao mesmo tempo, a polissemia que foi encontrada para os sentidos das competências pode ser também compreendida como uma abertura intrínseca em sua concepção.

Assim, não se trata de buscar identificar ou delimitar formas para trabalhá-las, mas desdobrar um leque de possibilidades que podem vir a ser contempladas, em diferentes graus e espaços. Isso impõe, então, a necessidade de definições dos sentidos desejados pelos docentes, em cada situação e contexto dado.

Considerando a questão central investigada nesse trabalho, a saber: como se mantêm ou são alterados os sentidos atribuídos às competências quando se investiga seus sentidos em níveis de diferentes abrangências no campo da educação? Acreditamos ter sido possível verificar que; apesar de 
elementos básicos como as ideias de: situação, autonomia e interdisciplinaridade estarem presentes em quase todos os contextos em que se pretende adotar um ensino por competências, ocorrem alterações no sentido adotado quando é feita a comparação vertical das competências.

O fato de termos específicos se repetirem desde o desenvolvimento teórico até a fala específica dos professores, quando esses se referem às competências, indica que pode haver uma estrutura geral do conceito que parece capaz de manter-se em diferentes níveis de abrangência, o que pode ser importante para caracterizar de maneira mais clara o quanto, determinada ação ou proposta, está alinhada com as competências.

Ao mesmo tempo, a mudança de níveis de abrangência parece exigir que os sentidos atribuídos às competências sofram algumas alterações. Alguns teóricos caracterizam as competências como objetos "pouco curriculares" (JONNAERT et al., 2010) ou problematizam a o estabelecimento de uma listagem de competências "a priori" (PERRENOUD, 2009). No entanto, os currículos brasileiros, a proposta da BNCC e a matriz de competências e habilidades do ENEM, estabelecem listagens de competências com base nas quais os cursos serão elaborados e os estudantes avaliados. Além disso, embora considerado um objeto pouco curricular pelos teóricos, discute-se, em diversos países, a elaboração de currículos baseados em competências, o que pressupõe, portanto, adaptações nos sentidos atribuídos ao conceito.

Além da comparação vertical, procuramos fazer uma comparação horizontalmente dos sentidos das competências, isto é, como mudam os sentidos das competências em um mesmo nível de abrangência. As mudanças de sentido mostraram-se maiores ou menores a depender do nível de abrangência em que a análise foi feita. No Nível Teórico, embora tenhamos investigado quatro diferentes autores, os sentidos atribuídos às competências foram muito convergentes. A divergência pareceu aumentar conforme se mudava de nível de abrangência. No Nível de Regulamentação foi possível perceber algumas alterações quando se compararam as DCN-1998 e DCN2012 ou na comparação entre os PCN e a proposta da BNCC. No Nível de Orientação Didática a divergência se mostrou ainda maior. Na comparação entre os manuais de professor dos livros didáticos analisados, as competências 
apareciam como recursos de valor e que deveriam ser consideradas no ensino ou como termos que precisavam ser citados mantendo-se uma proposta mais tradicional para a organização do conteúdo. Por fim, no Nível de Aplicação, a análise das respostas dos professores e professoras, mostraram, na comparação horizontal, a maior divergência. Pudemos verificar exemplos de práticas e perspectivas bastante tradicionais em contraste com outras bastante progressistas, embora a disposição inicial com relação às competências fosse positiva. Isto é, alguns docentes, embora concordassem que as competências eram importantes para o ensino e tivessem boa disposição em relação a elas, pareciam ter uma visão bastante tradicional do conceito.

Dessa forma, fica evidente a importância de que o currículo seja claro quanto ao trabalho por competências. Uma vez que se opte por um currículo baseado em competências, é necessário considerar que não basta apenas utilizar o termo na elaboração do texto, mas estruturas mais fundamentais precisam ser repensadas. A ideia de listagem de conteúdos ou até mesmo de competências, de avaliação padronizada ou de problemas estritamente escolares, é pouco adequada a uma visão mais ampla de desenvolvimento de competências. Para que este trabalho seja efetivo é preciso dimensionar as transformações necessárias, dialogando e formando os docentes.

Embora, como discutido no capítulo 1, seja inerente ao conceito de competências a multiplicidade de sentidos, é importante haver coerência no sentido adotado pelo currículo em comparação a outros documentos, manuais, exames até a ação docente, sem, contudo, pretender homogeneizar as ações, o que também contrariaria uma lógica de competências.

A importância do currículo se dá na medida em que, possuindo uma grande abrangência, tem condições de articular de maneira coerente as visões das instâncias inferiores, menos abrangentes e mais efetivas nas ações educacionais pontuais. Um currículo claro no que diz respeito às competências, e que dialoga com professores e professoras para compreender as expectativas e promover formação, pode contribuir para evitar grandes alterações nos sentidos das competências conforme se faça um deslocamento vertical na análise das competências em diferentes instâncias como 
apresentado na Figura 1.1. O que garante também, maior coerência nas comparações horizontais em cada nível de análise.

Em relação à disciplina de Física, pudemos verificar a relevância da discussão sobre competências. Tanto os materiais didáticos quanto os exemplos específicos dos itens ENEM envolviam conhecimento de Física. Em especial, grande parte dos docentes que responderam ao questionário ministravam a disciplina de Física. Nesse contexto as competências se mostram de grande relevância, sobretudo no que diz respeito a simular a realidade por meio de situações que exijam uma resposta do sujeito. A ideia de atribuir significado real, e ainda mais, relevância social para os conhecimentos Físicos é pouco explorada no ensino tradicional, mas de grande relevância para o ensino por competências.

\section{Eficácia, valores e competências}

A discussão teórica das competências também se apoiou em elementos que aparecem em quase todas as definições apresentadas. Um elemento importante é o conceito de "eficácia". Tanto Perrenoud (1999) quanto Jonnaert et al. (2010) e Zabala e Arnau (2009) utilizam esse termo para se referir à maneira como a resposta à situação apresentada deve ser apresentada. É preciso, no entanto, discutir o que se espera quando se fala em uma "resposta eficaz".

De acordo com o dicionário Aurélio online, eficácia é o que "produz determinado efeito; que efetua o que promete ou o que se espera; que causa o resultado inicialmente pretendido" ${ }^{35}$. Portanto, no sentido estrito da palavra, um sujeito competente deve mobilizar os recursos, de diversas naturezas, a ele disponibilizados de modo a não só apresentar uma resposta à situação apresentada, mas uma resposta que solucione o problema enfrentado. Essa abordagem suscita diversas dificuldades. Perrenoud (2013) problematiza esta questão.

Poderíamos, ou deveríamos, considerar como recursos 'disposições' como a coragem, a empatia, o sangue frio, o rigor, a tolerância, a lucidez, a sinceridade, a má-fé, a preguiça, a perseverança, a humildade, a autoestima, o respeito pelo próximo, o ardil ou a

\footnotetext{
${ }^{35}$ Disponível em: https://dicionariodoaurelio.com/eficaz. Acessado: 19 mai 2018.
} 
dissimulação, a arte de mentir, o equilíbrio, a paciência ou a impaciência? Percebemos que algumas dessas disposições não são unanimemente valorizadas. Porém, se focarmos a ação eficaz, nada obriga a valorizar apenas os recursos moral ou politicamente corretos. (PERRENOUD, 2013, p. 50)

Em princípio, um sujeito pode mobilizar de maneira articulada todos os recursos que lhe são disponíveis e ainda assim não ser capaz de produzir o efeito desejado ou prometido como resposta à situação enfrentada. Um médico pode tratar uma doença grave de seu paciente mobilizando recursos cognitivos e articulando-os com recursos materiais de tratamentos e medicamentos dos mais avançados. Ele pode convencer o paciente a seguir os passos do tratamento e, ainda assim, não alcançar a cura esperada, ou seja, a resposta apresentada foi ineficaz. A partir disso poderia concluir-se que o médico em questão não seja um profissional competente de modo geral? Ou que mesmo nessa situação não tenha sido competente?

Fato é que, mesmo quando a mobilização articulada dos recursos é feita da maneira mais correta possível, a eficácia da resposta depende de fatores que não podem ser controlados pelo sujeito em questão. Mas como saber se os recursos foram mobilizados da melhor maneira possível se o resultado alcançado foi ineficaz?

Mas, alcançar um resultado positivo, de maneira circunstancial, pode dizer menos sobre o desenvolvimento de uma competência do que a análise do processo de construção de resposta à situação apresentada. O fracasso inclusive pode ser um poderoso agente de desenvolvimento de competências.

Perguntas a serem feitas são se o resultado positivo foi obtido como resposta direto das ações do sujeito ou independente delas? O paciente apresentou melhora em seu estado por conta da ação competente do médico ou por se tratar de uma doença viral que seria combatida naturalmente pelo sistema imunológico do paciente?

Da mesma forma o fracasso. A piora do paciente foi resultado da ação incompetente ou negligente do médico, ou por conta de complicações na saúde do paciente que fugiam ao controle do profissional.

Pensar em uma avaliação das competências obriga que se acompanhe o processo de enfrentamento da situação e não que apenas se compare o 
resultado apresentado com um padrão ou modelo estabelecido a priori. É no enfrentamento da situação, no levantamento de possibilidades, no momento de mobilizar os recursos que a competência se manifesta e isso esta de acordo com o que foi apresentado no capítulo 2, a respeito da visão de competência dos teóricos. Questiona-se, portanto, a escolha do termo "resposta eficaz" nas definições de competências apresentadas no capítulo 2. Claro que, no campo profissional, nenhum paciente quer contribuir através do fracasso para 0 desenvolvimento da competência de seu médico sendo o exemplo de resposta ineficaz das ações desse médico, ou de qualquer outro profissional. Mas em educação, é preciso um olhar mais cuidadoso para as respostas ineficazes ou aquilo que se considera uma falha.

\section{Ética e competências}

Outro ponto delicado das definições teóricas de competências aparece mais claramente em Jonnaert et al. (2010). Este autor diz que as respostas às situações devem ser socialmente aceitáveis. Por um lado, é interessante notar como as competências devem levar em conta o contexto social no qual o sujeito está envolvido, ou seja, a resposta apresentada à situação não deve ser pensada como indiferente, mas como uma ação que potencialmente afeta a sociedade na qual o sujeito se insere. É também importante destacar a dimensão ética das competências, uma vez que a resposta não pode ser eficaz a qualquer custo, como discutimos no capítulo 2. Por outro lado, é importante a discussão sobre a sociedade em que o sujeito está inserido, suas nuanças e contradições, seus grupos e subgrupos. No Brasil, por exemplo, a resposta apresentada a uma situação pode ser aceitável para um setor da sociedade, mas não para outro. Do ponto de vista mundial a situação é muito mais complexa, pois uma resposta aceitável em sociedades ocidentais pode ser considerada absurda em sociedades orientais.

O que fica claro, portanto é a necessidade de que se discuta a sociedade, a filosofia, a ética, a estética etc. $O$ desenvolvimento de competências deve ser intrinsecamente associado a discussões dessa natureza. 
Da mesma forma sobre o "saber ser" e os "valores", termos mais presentes no texto de Zabala e Arnau (2010), é preciso perguntar qual é o conjunto de valores que se pretende desenvolver com as competências. De quem são esses valores? A partir dos interesses de qual grupo se definirão quais são os valores apropriados para o ensino? $O$ que se percebe é a necessidade de que se discuta a sociedade e suas interações.

Novamente, pensar na discussão de valores profissionais, embora não seja simples, é menos complexo do que no campo educacional. Empresas diferentes possuem valores diferentes, os profissionais podem, ou não, identificar-se com esses valores. A possibilidade de que, no campo da educação, escolas diferentes possam eleger diferentes valores e os alunos e as famílias possam identificar-se ou não com eles, deve ser evitada. Essa postura promoveria uma cultura de segregação e afastamento, intensificando desigualdades e não contribuindo para eliminá-las. É preciso, portanto discutir sobre, que tipo de sociedade se quer? Que tipo de cidadãos se deseja formar para compor esta sociedade? Quais são os valores básicos e comuns que a educação deve procurar promover junto a estes estudantes. E mais uma vez discussões de natureza social e filosófica mostram sua importância para o real desenvolvimento de uma educação por competências.

Nesse sentido, destaca-se a potencialidade das competências de desenvolverem o pensamento crítico dos sujeitos. O processo de ensino tradicional, baseado em reprodução, procedimento e desempenho, não só não precisa, mas tem seu processo comprometido, caso questões como as colocadas anteriormente sejam apresentadas para discussão.

Trazer à tona a necessidade dessas discussões é de grande importância, pois se percebe que as competências tem tido presença importante no cenário nacional de educação. Como se apresentou no capítulo 4 , diretrizes, documentos e propostas curriculares e os exames de avaliação de ensino, tem se baseado no conceito de competência. Contudo, se o termo é utilizado, mas a ele são atribuídos diferentes sentidos, a comunicação entre os diferentes âmbitos é prejudicada. Dessa forma, também é preciso cuidado ao se analisar as críticas às competências. Algumas dessas críticas referem-se às competências como apresentadas nos documentos oficiais, que não 
necessariamente carregam 0 mesmo sentido daquelas discutidas pelos teóricos. É importante lembrar que para os próprios teóricos, mais claramente em Jonnaert et al (2010), as competências são um conceito pouco curricular. Então, os documentos curriculares precisam, nessa transposição, adaptar sentidos para ser possível o trabalho a partir deste conceito. Da mesma forma, os materiais didáticos e os próprios professores precisam transpor os sentidos do conceito para que se adapte as situações em que será aplicado.

\section{Quando não se fala em competência}

Queremos aqui, fazer alguns paralelos entre características específicas das competências e o trabalho de Paulo Freire. Sabemos que tal comparação é frágil em diversos aspectos, sobretudo por que Freire não desenvolveu o conceito de competência e aqueles que o fizeram, não necessariamente o fizeram baseados nele. Mas entendemos que um ensino baseado em competências possui potencialidades para desenvolver alguns princípios encontrados na obra de Paulo Freire.

Freire (2011) afirma que

Quando o homem compreende sua realidade, pode levantar hipóteses sobre o desafio dessa realidade e procurar soluções. Assim, pode transformá-la e com seu trabalho pode criar um mundo próprio: seu eu e suas circunstâncias. (FREIRE, 2011, p.16).

O autor atribui ao sujeito a capacidade de alterar sua realidade. Mas para que isso aconteça, é preciso ser capaz de compreender essa realidade e considerar suas circunstâncias.

As competências trazem também consigo, um discurso de superação do conteúdo pelo conteúdo. Como Perrenoud (2009) chama a atenção, não se trata de negar conteúdos, mas de dar a eles significado no cotidiano e na vida do estudante, sem o que ele se torna um saber inútil. Sobre isso, Freire (2001) afirma que

Em outras palavras: por mais fundamentais que sejam os conteúdos, a sua importância efetiva não reside apenas neles, mas na maneira como sejam apreendidos pelos educandos e incorporados à sua prática. Ensinar conteúdos, por isso, é algo mais sério e complexo do que fazer discursos sobre seu perfil. (FREIRE, 2001, p.42). 
Assim como Freire, a lógica de competências procura se contrapor a um ensino tradicional, memorístico e desconectado da realidade. A este tipo de ensino Freire (1987) chama de "educação bancária" cuja

tarefa indeclinável é 'encher' os educandos dos conteúdos de sua narração. Conteúdos que são retalhos da realidade, desconectados da totalidade em que se engendram e em cuja visão ganhariam significação. (FREIRE, 1987, p. 33).

Entendemos que existem outros paralelos possíveis entre a pedagogia de Paulo Freire e o conceito de competência, mas estes exemplos são suficientes para compreender a potencialidade desse conceito.

\section{Uma outra perspectiva}

Considerando o exposto ao longo deste trabalho e em especial as discussões do presente capítulo, entendemos que a discussão e o aprofundamento teórico e metodológico em relação às competências são de extrema importância para o avanço, com qualidade, das reformas que se propõe na educação. Para tanto, e considerando a característica polissêmica das competências, gostaríamos de apresentar uma proposta de definição que acreditamos considerar alguns dos pontos aqui discutidos.

As competências se manifestam e se desenvolvem no enfrentamento de uma situação, ou de uma família de situações, que exige a articulação de recursos de natureza cognitiva, material, social, emocional ou qualquer outra adequada ao tratamento da situação, considerando as consequências sociais e éticas das ações empregadas na tentativa de solução. (Elaborado pelo autor)

Essa definição não se pretende definitiva, nem mesmo completa. Mas contem alguns dos entendimentos adquiridos por meio da elaboração deste trabalho.

Acreditamos que as discussões a respeito das competências merecem aprofundamento e ampliação de pesquisa, sobretudo no que diz respeito às metodologias que podem ser úteis, tanto no desenvolvimento quanto na avaliação das competências desenvolvidas. Pietrocola (2011) apresenta a metodologia de Aprendizagem Baseada em Projetos. Sua apresentação não especifica como esse tipo de metodologia se articularia com o desenvolvimento 
de competências, mas é possível perceber nessa proposta a potencialidade de apresentar aos alunos, situações que simulem a realidade, condição básica para que se desenvolvam competências de acordo com os teóricos. Outras discussões a este respeito têm sido feitas como em

Segundo Penuel (1999), o modelo de aprendizagem baseada em projetos, em conjunto com a utilização de novas tecnologias, traz um novo sentido para a aprendizagem, pois ajuda os estudantes a desenvolverem habilidades e competências para a vida numa sociedade baseada no conhecimento e altamente tecnológica. (TOYOHARA et al., 2010, p.3)

No artigo, os autores destacam a importância da metodologia de Aprendizagem Baseada em Projetos para o desenvolvimento de competências e habilidades de acordo com o trabalho de Perrenoud.

Considerando as mudanças anunciadas pelas reformas educacionais e pela BNCC, é imprescindível que a pesquisa na área de educação se desenvolva no sentido de prover maior entendimento a respeito das competências, contribuindo também para a formação de novos professores e professoras, e para a formação continuada daqueles e daquelas que desenvolvem seu trabalho. 


\section{REFERÊNCIAS}

AMADIO, M. A rapid assessment of curricula for general education focusing on cross-curricular themes and generic competences or skills. AFA: Teaching and learning: Achieving quality for all, Unesco, Paris, 2013.

ARANHA, M. L. A. Filosofia da Educação. $1^{\text {a }}$ ed. Ed Moderna. São Paulo, 1990.

ARRUDA, M. C. C. Qualificação versus Competência. Boletim Técnico do SENAC, Rio de Janeiro, v.26, n.2, maio/ago., p.19-27, 2000.

BASSO, M. Exames padronizados, como o Enem, podem atrapalhar mais do que ajudar. Gazeta do Povo, jul. 2017.

BLIKSTEIN, I. Kaspar Hauser ou a fabricação da realidade. Cultrix, São Paulo, 2009.

BRASIL. Base Nacional Comum Curricular - Texto preliminar. MEC, Brasília, 2018.

. Decreto-Lei no 93, de 21 de dezembro de 1937, Cria o instituto nacional do livro. Diário oficial, Brasília, DF, 27 de Dez de 1937. Seção 1, p. 25586.

Edital de convocação 01/2014 - CGPLI Edital de convocação para o processo de inscrição e avaliação de obras didáticas para o Programa Nacional do Livro didático PNLD 2016. MEC, Brasília, 2014.

Edital de convocação 01/2017 - CGPLI Edital de convocação para o processo de inscrição e avaliação de obras didáticas para o Programa Nacional do Livro didático PNLD 2019. MEC, Brasília, 2017.

Programa Nacional do livro didático: Histórico. $<$ http://www.fnde.gov.br/programas/programas-do-livro/livrodidatico/historico>. Acesso: 04 de jan 2018.

Programa Nacional do livro didático: Dados estatísticos. <http://www.fnde.gov.br/programas/programas-do-livro/livrodidatico/dados-estatisticos>. Acessado em 06 de jan de 2018.

Escolha dos livros aprovados pelo PNLD 2018 começa dia 21. $<$ http://portal.mec.gov.br/component/tags/tag/31952>. Acessado em 06 de jan de 2018.

Guia digital: PNLD 2018. <http://www.fnde.gov.br/pnld-2018/>. Acessado em 06 jan de 2018.

Diretrizes curriculares nacionais para o ensino médio. MEC, Brasília, 2001. 
Diretrizes curriculares nacionais para o ensino médio. MEC, Brasília, 2012.

Equipamentos e materiais didáticos. Brasília, UnB, 2007.

Exame Nacional do Ensino Médio (ENEM): Fundamentação Teórico-Metodológica. MEC, Brasília, 2005.

. Parâmetros Curriculares Nacionais (PCN). MEC, Brasília, 1998.

. Parâmetros Curriculares Nacionais: Complementos (PCN+). MEC, Brasília, 2000.

BARDIN, L. Análise de Conteúdo. Lisboa, Portugal; Edições 70, LDA, 2009.

BRICCIA, V., CARVALHO, A. M. P. Complexidade e competências docentes na inovação curricular. ENPEC, Campinas, 2012.

DIAS, I. S. Competências e educação: conceito e significado pedagógico. Revista Semestral da Associação Brasileira de Psicologia Escolar e Educacional, SP. Volume 14, Número 1, Janeiro/Junho de 2010: 7378.

FLEURY, M. T. L, FLEURY, A. Construindo o conceito de competência. Revista de administração contemporânea, Edição Especial, 2001.

FREIRE, P. Educação e Mudança. 12ª ed., Paz e Terra, São Paulo, 2011.

FREIRE, P. Pedagogia do Oprimido. 17ª ed., Paz e Terra, São Paulo, 1996.

FREIRE, P. Política e Educação. 5ª ed., Cortez Editora, São Paulo, 2001.

GALIAN, C. V. A. Os PCN e a elaboração de propostas curriculares no Brasil. Cadernos de Pesquisa. V. 44, n. 153, jul./set 2014, p.648-669.

JONNAERT, P. Competências e socioconstrutivismo: um quadro teórico. Porto Alegre, Instituto Piaget, 2009.

JONNAERT, P., ETTAYEBI, M., DEFISE, R. Currículo e Competências. Artmed, Porto Alegre, 2010.

KIMURA, I. F. L. A teoria de resposta ao Item aplicada ao contexto de avaliações padronizadas no Brasil. Instituto Tecnológico de Aeronáutica. São Carlos. 2013.

KRASILCHIK, M. As relações pessoais na escola e a avaliação. Thomson Learning. São Paulo. 2001.

LANCRIN, S. Teaching, assessing and learning creative and critical thinking skills in education. OCDE. Disponível em: http://www.oecd.org/education/ceri/assessingprogressionincreativeandcritic althinkingskillsineducation.htm. Acessado em: 20 fev 2018. 
LIBÂNEO, J.C., OLIVEIRA, J.F. e TOSCHI, M.S., Educação Escolar: políticas, estrutura e organização. São Paulo, Cortez Editora, 2012.

LOPES, A. C. Políticas de integração curricular. Rio de Janeiro, Ed. UERJ, 2008.

LOPES, A. C., MACEDO, E. Teorias de currículo. Cortez Editora. São Paulo, 2011.

LUCKESI, C. C. 0 que é mesmo o ato de avaliar a aprendizagem? Pátio. Porto alegre: ARTMED. Ano 3, n. 12 fev./abr. 2000. MACEDO, L. Competências na educação. 2008.

MOEHLECKE, S. O ensino médio e as novas diretrizes curriculares nacionais: entre recorrências e novas inquietações. Revista Brasileira de Educação, v.17, n. 49, jan-abr 2012.

MORAES, R. e GALIAZZI, M.C. Análise Textual Discursiva. ljuí, Ed. Unijuí, 2007.

MOREIRA, A. F., ARROYO, M. G., BEAUCHAMP, J., PAGEL, S. D., NASCIMENTO, A. R. Currículo, Conhecimento e Cultura. MEC, Brasília, 2007.

MONTEIRO, R. A. C.; GONZÁLEZ, L. M.; GARCIA, A. Barreta. Lei de Diretrizes e Bases da Educação Nacional: o porquê e seu contexto histórico. Revista Eletrônica de Educação - UFSCar, v.5, n.2, jun./dez. 2011. p. $82-95$.

OCDE, Teaching and learning: achieving quality for all; EFA global monitoring report, 2013-2014; 2014.

PAIVA, S. A presença do conceito de competências no ENEM, da fundamentação teórico-metodológica à aplicação dos exames. 55 folhas. Monografia, Licenciatura em Física, Instituto de Física da Universidade de São Paulo, São Paulo, 2014.

PEIXOTO, K. C. Q. C. Novo ENEM: o que mudou? Uma investigação dos conceitos de Física abordados no exame. XII Encontro de Pesquisa em Ensino de Física. Águas de Lindóia, 2010.

PERRENOUD, P. Construir as competências desde a escola. Artmed, Porto Alegre, 1999.

PERRENOUD, P. De uma metáfora a outra: Transferir ou mobilizar conhecimentos. Em O enigma da competência em educação, p. 47 a 63. Artmed, Porto Alegre, 2004.

PERRENOUD, P. Desenvolver competências ou ensinar saberes? A escola que prepara para a vida. Penso, Porto Alegre, 2013. 
PERRENOUD, P. Formação Continuada e Obrigatoriedade de Competências na Profissão de Professor. Faculdade de Psicologia e Ciências da Educação, Universidade de Genebra 1998.

PRIMI, R., SANTOS, A., VENDRAMINI, C. M., TAXA, F., MULLER, F. A., LUKJANEKO, M. F., SAMPAIO, I. S. Competências e Habilidades Cognitivas: Diferentes Definições do Mesmo Construto. Psicologia: Teoria e Pesquisa, vol. 17, no. 2, Brasília, 2001.

PIETROCOLA, M.; POGIBIN, A.; ANDRADE, R.; ROMERO, T. R.; Física em contexto. Manual do Professor. Ed. FRD, São Paulo, 2011.

RICARDO, E. C. Competências, interdisciplinaridade e contextualização: dos Parâmetros Curriculares Nacionais a uma compreensão para o ensino das ciências. Tese - UFSC, Florianópolis, 2005.

RICARDO, E. C. CUSTÓDIO, J. F. REZENDE, M. F. Comentários sobre as Orientações Curriculares de 2006 para o ensino da física. Revista Brasileira de Ensino de Física, v. 30, n. 2, 2401, 2008.

ROPÉ, F., TANGUY, L. (orgs.). Saberes e Competências: o uso de tais noções na escola e na empresa. Tradução Patrícia Chittoni Ramos e equipe do ILA-PUC/RS. Campinas-SP: Papirus, 1997.

RAMOS, M. N. A Pedagogia das Competências e a Psicologização das Questões Sociais. Boletim Técnico do SENAC, v.27, n.3, p. 27-35, $2001 b$.

SILVA, E. R. Uma reflexão sobre a ideia de competência e seu significado educacional. Tese - FEUSP, São Paulo, 2010.

SILVA, M. R. Currículo Numa abordagem por competências: Transferência e mobilização de saberes. São Paulo, Cortez Editora, 2008.

TOYOHARA, D. Q. K., SENA, G. J., ARAÚJO, A. M., AKAMATSU, J. I. Aprendizagem Baseada em Projetos - uma nova Estratégia de Ensino para o Desenvolvimento de Projetos. PBL - Congresso Internacional. São Paulo, 2010.

UNESCO. Educação para a cidadania global: preparando alunos para os desafios do século XXI. Brasília, 2015.

UNESCO. Teaching and learning: achieving quality for all. AFA Global Monitoring Report, Paris, 2014.

YAMAMOTO, K.; FUKE, L. F. Física para o ensino médio. Manual do Professor. São Paulo, Ed. Saraiva, 2010.

ZABALA, A., ARNAU, L. Como aprender e ensinar competências. Tradução Carlos Henrique Lucas Lima. Porto Alegre, Artmed, 2010. 


\section{APÊNDICE A - ITENS ENEM 2013}

\section{ENEM 2013 - QUESTÃO 53}

Uma manifestação comum das torcidas em estádios de futebol é a ola mexicana. Os espectadores de uma linha, sem sair do lugar e sem se deslocarem lateralmente, ficam de pé e se sentam, sincronizados com os da linha adjacente. O efeito coletivo se propaga pelos espectadores do estádio, formando uma onda progressiva, conforme ilustração.

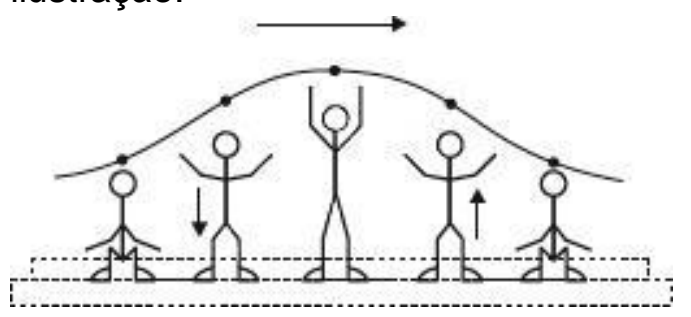

Calcula-se que a velocidade de propagação dessa "onda humana" é $45 \mathrm{~km} / \mathrm{h}$ e que cada período de oscilação contém 16 pessoas, que se levantam e sentam organizadamente distanciadas entre si por $80 \mathrm{~cm}$.

Nessa ola mexicana, a frequência da onda, em hertz, é um valor mais próximo de
a) 0,3 .
b) 0,5 .
c) 1,0 .
d) 1,9 .
e) 3,7 .

\begin{tabular}{|c|c|}
\hline Tema & Frequência de propagação de uma onda. \\
\hline Conteúdo 1 & Equação fundamental da onda \\
\hline $\begin{array}{l}\text { Colocação da } \\
\text { pergunta }\end{array}$ & $\begin{array}{l}\text { A pergunta é clara e se relaciona com o } \\
\text { texto base. Contudo o conceito de "onda" } \\
\text { utilizado não está de acordo com o } \\
\text { encontrado em livros de nível médio, uma } \\
\text { vez que ondas são apresentadas como } \\
\text { transmissão de energia e na Ola existe } \\
\text { transmissão de informação. }\end{array}$ \\
\hline $\begin{array}{l}\text { Apresentação das } \\
\text { alternativas }\end{array}$ & $\begin{array}{l}\text { Bem apresentadas, em ordem crescente, } \\
\text { respeitando paralelismos. }\end{array}$ \\
\hline Resolução & $\begin{array}{l}\text { O aluno deve converter a unidade de } \mathrm{Km} / \mathrm{h} \\
\text { para } \mathrm{m} / \mathrm{s} \text { obtendo a velocidade de } 12,5 \mathrm{~m} / \mathrm{s} \\
\text { e determina o comprimento da onda } \\
\text { calculando } 16.0,8=12,8 \mathrm{~m} \text {. Aplicando v= } \lambda . f \\
\text { obtem } 12,5=12,8 . f \text { dessa forma } \mathrm{f} \sim 1,00 \text {. É } \\
\text { importante notar que o exercício fornece a } \\
\text { distância entre as pessoas como sendo de } \\
80 \mathrm{~cm} \text {, parecendo considerar as pessoas } \\
\text { como objetos pontuais, contudo uma pessoa } \\
\text { de porte médio tem ocupa uma largura } \\
\text { muito próxima de } 80 \mathrm{~cm} \text {, se pessoas que o } \\
\text { ocupam } 80 \mathrm{~cm} \text { distanciam-se } 80 \text { cm o } \\
\text { comprimento da onda seria ao menos o } \\
\text { dobro, mas não acredito que isso altere a } \\
\text { frequência porque "metade" do comprimento } \\
\text { de onda se ergue a cada vez, o que causa } \\
\text { nova estranheza com relação à definição de } \\
\text { onda. }\end{array}$ \\
\hline Avaliação & $\begin{array}{l}\text { Tecnicista. A situação é possivelmente } \\
\text { conhecida e cotidiana para grande parte dos } \\
\text { alunos, mas a abordagem torna a questão } \\
\text { tecnicista servindo de pretexto para } \\
\text { aplicação de uma fórmula. Dificilmente } \\
\text { alguém nessa situação se preocuparia em } \\
\text { calcular a frequência da Ola ou teria alguma } \\
\text { ação a partir dessa informação, saber o } \\
\text { tempo que a Ola demora para dar uma volta } \\
\text { de modo que possa levantar e continuar a } \\
\text { brincadeira parece uma informação mais } \\
\text { útil. }\end{array}$ \\
\hline Habilidade & $\begin{array}{l}\text { H1 - Reconhecer características ou } \\
\text { propriedades de fenômenos ondulatórios ou } \\
\text { oscilatórios, relacionando-os a seus usos } \\
\text { em diferentes contextos. }\end{array}$ \\
\hline Ação & Aplicação de Fórmula \\
\hline
\end{tabular}




\section{ENEM 2013 - QUESTÃO 55}

Em viagens de avião, é solicitado aos passageiros o desligamento de todos os aparelhos cujo funcionamento envolva a emissão ou a recepção de ondas eletromagnéticas. O procedimento é utilizado para eliminar fontes de radiação que possam interferir nas comunicações via rádio dos pilotos com a torre de controle.

A propriedade das ondas emitidas que justifica 0 procedimento adotado é o fato de
a) terem fases opostas.
b) serem ambas audíveis.
c) terem intensidades inversas.
d) serem de mesma amplitude.
e) terem frequências próximas.

\begin{tabular}{|c|c|}
\hline Tema & $\begin{array}{l}\text { Interferência de ondas em comunicações } \\
\text { via rádio }\end{array}$ \\
\hline Conteúdo 1 & Ondulatória \\
\hline Conteúdo 2 & Radiação eletromagnética \\
\hline $\begin{array}{l}\text { Colocação da } \\
\text { pergunta }\end{array}$ & $\begin{array}{l}\text { Não é claro a quais ondas se refere. As de } \\
\text { comunicação entre avião e torre? As de } \\
\text { interferência? Ondas no geral? No caso da } \\
\text { terceira alternativa ondas de frequência } \\
\text { próxima não precisam interferir } \\
\text { necessariamente. }\end{array}$ \\
\hline $\begin{array}{l}\text { Apresentação das } \\
\text { alternativas }\end{array}$ & $\begin{array}{l}\text { Ordenadas por extensão. Paralelismo } \\
\text { semântico e sintático presentes. }\end{array}$ \\
\hline Resolução & $\begin{array}{l}\text { Ondas de frequência parecida devem } \\
\text { interferir umas com as outras, como no caso } \\
\text { de ondas emitidas por rádios piratas que } \\
\text { interferem nas comunicações de aeronaves. }\end{array}$ \\
\hline Avaliação & $\begin{array}{l}\text { Interpretativa. Este conhecimento auxilia o } \\
\text { estudante a interpretar um fenômeno e } \\
\text { compreender o procedimento de segurança } \\
\text { adotado por companhias aéreas. Também o } \\
\text { auxilia a compreender os limites do } \\
\text { procedimento uma vez que aparelhos que } \\
\text { trabalham em frequências distantes } \\
\text { daquelas utilizadas pelos aparelhos de } \\
\text { comunicação da aeronave não devem } \\
\text { interferir nessa comunicação. Embora } \\
\text { apresente alguns problemas de formulação } \\
\text { a abordagem da pergunta usa a Física para } \\
\text { interpretar o cotidiano, uma característica } \\
\text { das intenções do ENEM. }\end{array}$ \\
\hline Habilidade & $\begin{array}{l}\text { H21 - Reconhecer em textos de diferentes } \\
\text { gêneros, recursos verbais e não-verbais } \\
\text { utilizados com a finalidade de criar e mudar } \\
\text { comportamentos e hábitos. }\end{array}$ \\
\hline Ação & Utilização de esquemas \\
\hline
\end{tabular}




\section{ENEM 2013 - QUESTÃO 60}

Em um experimento, foram utilizadas duas garrafas PET, uma pintada de branco e a outra de preto, acopladas cada uma a um termômetro. No ponto médio da distância entre as garrafas, foi mantida acesa, durante alguns minutos, uma lâmpada incandescente. Em seguida, a lâmpada foi desligada. Durante o experimento, foram monitoradas as temperaturas das garrafas: a) enquanto a lâmpada permaneceu acesa e b) após a lâmpada ser desligada e atingirem equilíbrio térmico com o ambiente.

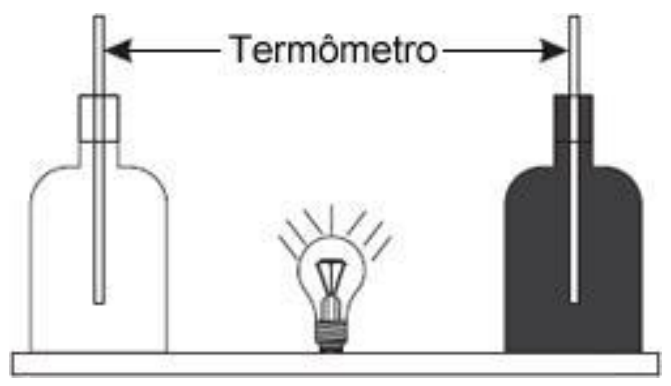

A taxa de variação da temperatura da garrafa preta, em comparação à da branca, durante todo experimento, foi

a) igual no aquecimento e igual no resfriamento.

b) maior no aquecimento e igual no resfriamento.

c) menor no aquecimento e igual no resfriamento.

d) maior no aquecimento e menor no resfriamento.

e) maior no aquecimento e maior no resfriamento.

\begin{tabular}{|c|c|}
\hline Tema & Variação de temperatura \\
\hline Conteúdo 1 & Calorimetria \\
\hline Conteúdo 2 & Radiação térmica \\
\hline $\begin{array}{l}\text { Colocação da } \\
\text { pergunta }\end{array}$ & É pertinente e dialoga com o texto base. \\
\hline $\begin{array}{l}\text { Apresentação das } \\
\text { alternativas }\end{array}$ & $\begin{array}{l}\text { Ordenadas por extensão. Paralelismo } \\
\text { semântico e sintático presentes. }\end{array}$ \\
\hline Resolução & $\begin{array}{l}\text { A absorção de calor pela garrafa preta é } \\
\text { maior do que pela garrafa branca, isso faz } \\
\text { com que essa garrafa atinja uma maior } \\
\text { temperatura, portanto no aquecimento a } \\
\text { taxa de variação de sua temperatura é } \\
\text { maior do que da garrafa branca. Como após } \\
\text { desligar a lâmpada as garrafas atingem o } \\
\text { equilíbrio térmico com o ambiente a } \\
\text { variação da temperatura da garrafa preta } \\
\text { também é maior já que no resfriamento sua } \\
\text { temperatura inicial é maior. O fato de um } \\
\text { corpo preto ter taxa de absorção igual à taxa } \\
\text { de irradiação é além do esperado para os } \\
\text { conhecimentos de ensino médio, mas se a } \\
\text { análise puder ser feita tendo em vista a } \\
\text { garrafa que atinge a maior temperatura o } \\
\text { exercício pode ser considerado adequado. } \\
\text { *ainda tenho dúvidas quanto a esta questão, } \\
\text { taxa de variação depende necessariamente } \\
\text { do tempo? }\end{array}$ \\
\hline Avaliação & $\begin{array}{l}\text { Interpretativa/transpositiva. Apesar de o } \\
\text { aparato ser exclusivo para a análise de um } \\
\text { fenômeno físico sua interpretação é geral e } \\
\text { pode ser estendida para diversas situações } \\
\text { no dia a dia do aluno, sendo um } \\
\text { conhecimento físico que permite interpretar } \\
\text { situações cotidianas. }\end{array}$ \\
\hline Habilidade & $\begin{array}{l}\text { H21 - Utilizar leis físicas e (ou) químicas } \\
\text { para interpretar processos naturais ou } \\
\text { tecnológicos inseridos no contexto da } \\
\text { termodinâmica e(ou) do eletromagnetismo. }\end{array}$ \\
\hline Ação & Utilização de esquema \\
\hline
\end{tabular}




\section{ENEM 2013 - QUESTÃO 69}

Para serrar os ossos e carnes congeladas, um açougueiro utiliza uma serra de fita que possui três polias e um motor. O equipamento pode ser montado de duas formas diferentes, $\mathrm{P}$ e Q. Por questão de segurança, é necessário que a serra possua menor velocidade linear.

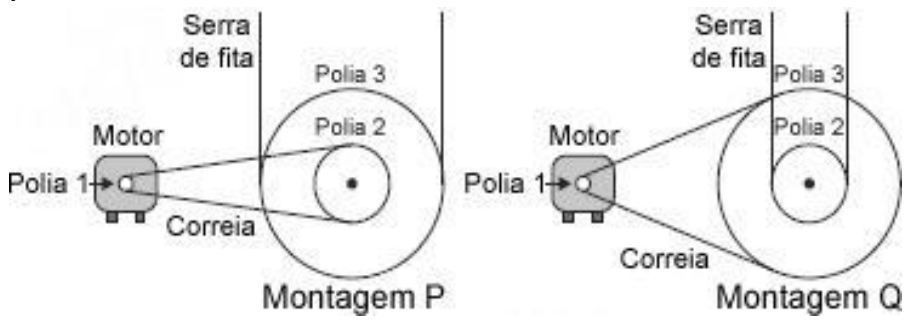

Por qual montagem o açougueiro deve optar e qual a justificativa desta opção?

\section{a) Q, pois as polias 1 e 3 giram com velocidades lineares iguais em pontos periféricos e a que tiver maior raio terá menor frequência.}

b) $Q$, pois as polias 1 e 3 giram com frequência iguais e a que tiver maior raio terá menor velocidade linear em um ponto periférico.

c) $P$, pois as polias 2 e 3 giram com frequências diferentes e a que tiver maior raio terá menor velocidade linear em um ponto periférico.

d) $P$, pois as polias 1 e 2 giram com diferentes velocidades lineares em pontos periféricos e a que tiver menor raio terá maior frequência.

e) Q, pois as polias 2 e 3 giram com diferentes velocidades lineares em pontos periféricos e a que tiver maior raio terá menor frequência.

\begin{tabular}{|c|c|}
\hline Tema & $\begin{array}{l}\text { Configuração para ajuste de velocidade } \\
\text { angular }\end{array}$ \\
\hline Conteúdo 1 & Polias e correias \\
\hline $\begin{array}{l}\text { Colocação da } \\
\text { pergunta }\end{array}$ & Clara, relacionada à situação, univoca. \\
\hline $\begin{array}{l}\text { Apresentação das } \\
\text { alternativas }\end{array}$ & $\begin{array}{l}\text { As alternativas são bem apresentadas. } \\
\text { Respeitam paralelismos, embora as } \\
\text { justificativas obriguem o aluno a ler algumas } \\
\text { alternativas para selecionar a correta, isso } \\
\text { parece justificado. }\end{array}$ \\
\hline Resolução & $\begin{array}{l}\text { Polias ligadas por uma correia possuem } \\
\text { mesma velocidade tangencial e, nesse } \\
\text { caso, a frequência depende do raio da polia. } \\
\text { Polias que giram no mesmo eixo possuem } \\
\text { mesma velocidade angular e a velocidade } \\
\text { tangencial depende do raio. A polia do } \\
\text { motor é a menor e quando ligada a polia } 3 \\
\text { fará com que ela tenha a mesma velocidade } \\
\text { tangencial portanto sua velocidade angular } \\
\text { será menor, dessa forma a velocidade } \\
\text { angular de } 2 \text { será igual à de } 3 \text { produzindo } \\
\text { uma velocidade tangencia da serra a menor } \\
\text { possível. }\end{array}$ \\
\hline Avaliação & $\begin{array}{l}\text { A situação é cotidiana, mas muito específica } \\
\text { para um profissional da área. A abordagem } \\
\text { é técnicista/interpretativa por que a partir } \\
\text { de conceitos de cinemática angular o } \\
\text { estudante pode interpretar os esquemas de } \\
\text { montagem e prever o que deve acontecer } \\
\text { ao sistema, mas não deve se esperar que o } \\
\text { estudante tenha alguma ação prática nesse } \\
\text { tipo de situação. }\end{array}$ \\
\hline Habilidade & $\begin{array}{l}\text { H18 - Relacionar propriedades físicas, } \\
\text { químicas ou biológicas de produtos, } \\
\text { sistemas ou procedimentos tecnológicos às } \\
\text { finalidades a que se destinam. }\end{array}$ \\
\hline Ação & Tomada de decisão \\
\hline
\end{tabular}




\section{ENEM 2013 - QUESTÃO 65}

Para oferecer acessibilidade aos portadores de dificuldades de locomoção, é utilizado, em ônibus e automóveis, o elevador hidráulico. Nesse dispositivo é usada uma bomba elétrica, para forçar um fluido a passar de uma tubulação estreita para outra mais larga, e dessa forma acionar um pistão que movimenta a plataforma. Considere um elevador hidráulico cuja área da cabeça do pistão seja cinco vezes maior do que a área da tubulação que sai da bomba. Desprezando o atrito e considerando uma aceleração gravitacional de $10 \mathrm{~m} / \mathrm{s}^{2}$, deseja-se elevar uma pessoa de $65 \mathrm{~kg}$ em uma cadeira de rodas de $15 \mathrm{~kg}$ sobre a plataforma de $20 \mathrm{~kg}$. Qual deve ser a força exercida pelo motor da bomba sobre o fluido, para que o cadeirante seja elevado com velocidade constante?
a) $20 \mathrm{~N}$.
b) $100 \mathrm{~N}$.
c) $200 \mathrm{~N}$.
d) $1000 \mathrm{~N}$.
e) $5000 \mathrm{~N}$.

\begin{tabular}{|c|c|}
\hline Tema & Força transmitida por fluidos \\
\hline Conteúdo 1 & Princípio de Pascal \\
\hline Contexto & Elevador hidráulico. \\
\hline $\begin{array}{l}\text { Colocação da } \\
\text { pergunta }\end{array}$ & $\begin{array}{l}\text { Clara, relacionada à situação, mas não } \\
\text { restrita a ela, poderia ser aplicada a } \\
\text { qualquer sistema. }\end{array}$ \\
\hline $\begin{array}{l}\text { Apresentação das } \\
\text { alternativas }\end{array}$ & $\begin{array}{l}\text { Apresentadas em ordem crescente, a } \\
\text { unidade poderia ser incorporada ao } \\
\text { enunciado. }\end{array}$ \\
\hline Resolução & $\begin{array}{l}\text { A força exercída sobre o pistão é } \\
\mathrm{F} 2=(65+15+20) .10=1000 \mathrm{~N} \text {, que é o peso } \\
\text { da massa que deve ser suspensa pelo } \\
\text { elevador. A área do cabeçote do pistão em } \\
\text { relação à área da tubulação é dada por } \\
\mathrm{A} 2=5 . \mathrm{A} 1 . \text { Aplicando } \mathrm{F} 1 / \mathrm{A} 1=\mathrm{F} 2 / \mathrm{A} 2 \text { temos } \\
\mathrm{F} 1 / \mathrm{A} 1=1000 / 5 . \mathrm{A} 1=200 \mathrm{~N} \text {. }\end{array}$ \\
\hline Avaliação & $\begin{array}{l}\text { Tecnicista. A situação é cotidiana é } \\
\text { importante de ser avaliada, contudo a } \\
\text { abordagem a torna a questão tecnicista uma } \\
\text { vez que o calculo da força exercida por um } \\
\text { elevador não é uma informação prática } \\
\text { neste caso, salvo se houvessem dois } \\
\text { elevadores com diferentes capacidades e o } \\
\text { usuário desejasse saber se poderia utilizar } \\
\text { qualquer um dos dois, mas mesmo assim a } \\
\text { força aplicada pelo motor não é uma } \\
\text { informação importante, mas sim a força } \\
\text { exercida pelo pistão. Neste caso uma } \\
\text { informação sobre o tempo necessário para } \\
\text { erguer o cadeirante também seria uma } \\
\text { informação prática que permitiria ao usuário } \\
\text { algum tipo de ação ou decisão. De forma } \\
\text { muito estrita poderia se dizer que a } \\
\text { informação pedida é importante para um } \\
\text { técnico responsável pela manutenção do } \\
\text { elevador, mas nesse caso a situação } \\
\text { problema deveria ser alterada. }\end{array}$ \\
\hline Habilidade & $\begin{array}{l}\text { H18 - Relacionar propriedades físicas, } \\
\text { químicas ou biológicas de produtos, } \\
\text { sistemas ou procedimentos tecnológicos às } \\
\text { finalidades a que se destinam. }\end{array}$ \\
\hline Ação & Aplicação de fórmula \\
\hline
\end{tabular}




\section{ENEM 2013 - QUESTÃO 66}

Um eletricista analisa o diagrama de uma instalação elétrica residencial para planejar medições de tensão e corrente em uma cozinha. Nesse ambiente existem uma geladeira $(G)$, uma tomada $(T)$ e uma lâmpada (L), conforme a figura. O eletricista deseja medir a tensão elétrica aplicada à geladeira, a corrente total e a corrente na lâmpada. Para isso, ele dispõe de um voltímetro (V) e dois amperímetros (A).

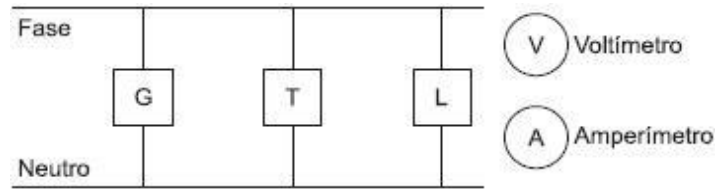

Para realizar essas medidas, o esquema da ligação dessas instrumentos está representado em:

a) Neutro
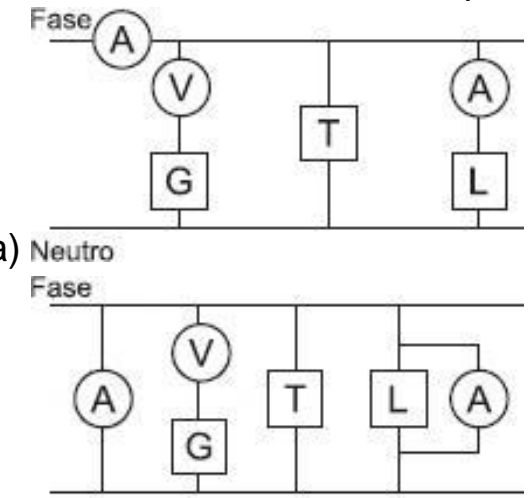

b) Neutro

$$
\text { Fase }
$$

C) Neutro

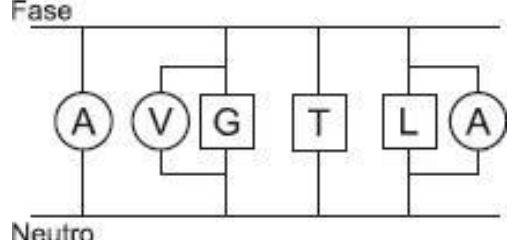

Fase

d) Neutro

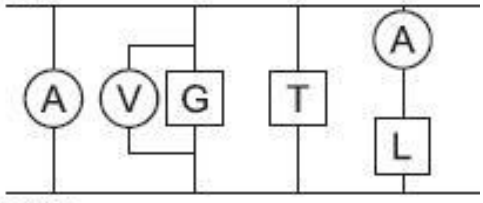

Fase

e) Neutro

\begin{tabular}{|c|c|}
\hline Tema & Modelo de circuito \\
\hline Conteúdo 1 & Ligações mistas \\
\hline Conteúdo 2 & Medidores ideias \\
\hline $\begin{array}{l}\text { Colocação da } \\
\text { pergunta }\end{array}$ & Clara, relacionada à situação, univoca. \\
\hline $\begin{array}{l}\text { Apresentação das } \\
\text { alternativas }\end{array}$ & $\begin{array}{l}\text { As alternativas apresentam esquemas } \\
\text { gráficos. O aluno deve consultá-los afim de } \\
\text { selecionar o mais adequado, mas a análise } \\
\text { deve ser rápida. }\end{array}$ \\
\hline Resolução & $\begin{array}{l}\text { Para saber a tensão de um componente do } \\
\text { circuito o voltímetro deve ser ligado em } \\
\text { paralelo com este, para saber a corrente de } \\
\text { um componente ou do circuito o } \\
\text { amperímetro deve ser ligado em serie com } \\
\text { cada um destes respectivamente, o } \\
\text { esquema E é o que apresenta as ligações } \\
\text { adequadas. }\end{array}$ \\
\hline Avaliação & $\begin{array}{l}\text { Prático. O conhecimento do conceito e a } \\
\text { interpretação do esquema fornecem } \\
\text { ferramenta para que o estudante tome } \\
\text { atitude prática na resolução de um } \\
\text { problema, no caso determinar a tensão e a } \\
\text { corrente de componentes de um circuito. } \\
\text { Embora a contextualização seja feita com } \\
\text { um profissional da área esse tipo de } \\
\text { situação e corriqueira e pode ser enfrentada } \\
\text { por leigos no assunto, o domínio de } \\
\text { conceitos básicos ajuda a evitar acidentes. }\end{array}$ \\
\hline Habilidade & $\begin{array}{l}\text { H6 - Relacionar informações para } \\
\text { compreender manuais de instalação ou } \\
\text { utilização de aparelhos, ou sistemas } \\
\text { tecnológicos de uso comum. H17 }\end{array}$ \\
\hline Ação & Tomada de decisão \\
\hline
\end{tabular}




\section{ENEM 2013 - QUESTÃO 67}

Desenvolve-se um dispositivo para abrir automaticamente uma porta no qual um botão, quando acionado, faz com que uma corrente elétrica $i=6$ A percorra uma barra condutora de comprimento $L=5 \mathrm{~cm}$, cujo ponto médio está preso a uma mola de constante elástica $\mathrm{k}=5 \times 10^{-2} \mathrm{~N} / \mathrm{cm}$. O sistema mola-condutor está imerso em um campo magnético uniforme perpendicular ao plano. Quando acionado o botão, a barra sairá da posição de equilíbrio a uma velocidade média de $5 \mathrm{~m} / \mathrm{s}$ e atingirá a catraca em 6 milisegundos, abrindo a porta.

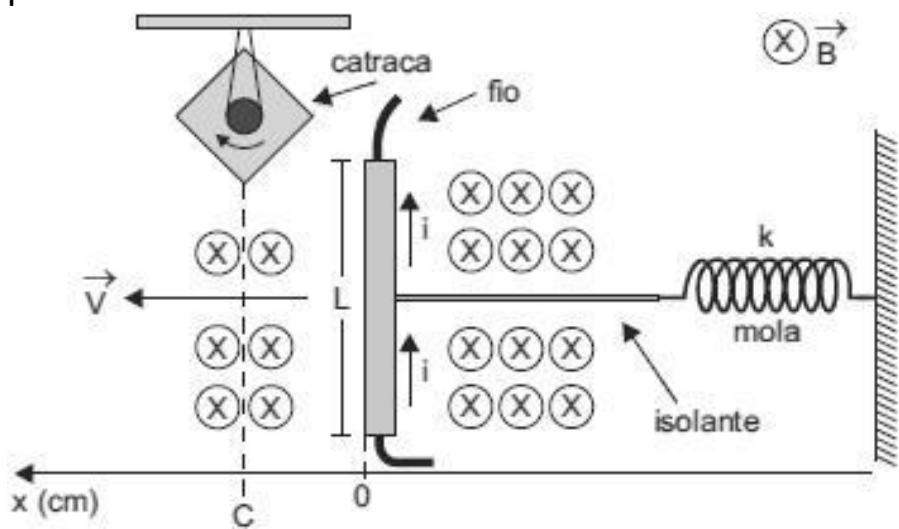

A intensidade do campo magnético, para que o dispositivo funcione corretamente, é de
a) $5 \times 10^{-1} \mathrm{~T}$.
b) $5 \times 10^{-2} \mathrm{~T}$.
c) $5 \times 10^{1} \mathrm{~T}$.
d) $2 \times 10^{-2} \mathrm{~T}$.
e) $2 \times 10^{0} \mathrm{~T}$.

\begin{tabular}{|c|c|}
\hline Tema & Força sobre condutor \\
\hline Conteúdo 1 & Força magnética \\
\hline $\begin{array}{l}\text { Colocação da } \\
\text { pergunta }\end{array}$ & Clara e relacionada ao contexto. \\
\hline $\begin{array}{l}\text { Apresentação das } \\
\text { alternativas }\end{array}$ & $\begin{array}{l}\text { A unidade poderia ter sido incorporada ao } \\
\text { enunciado. }\end{array}$ \\
\hline Resolução & $\begin{array}{l}\text { Determina a força magnética necessária } \\
\text { para abertura do portão. }\end{array}$ \\
\hline Avaliação & $\begin{array}{l}\text { Tecnicista. Determinar a intensidade do } \\
\text { campo elétrico não gera ação prática do } \\
\text { estudante, nem necessariamente o ajuda a } \\
\text { interpretar o fenômeno. Claro que deve } \\
\text { haver grande habilidade para a } \\
\text { interpretação da situação, mas o seu } \\
\text { resultado não gera ação, é um pretexto para } \\
\text { um cálculo complicado. Portanto o recurso } \\
\text { mobilizado envolve a aplicação de uma } \\
\text { formulação clássica de Física para a } \\
\text { determinação do campo magnético. }\end{array}$ \\
\hline Habilidade & $\begin{array}{l}\text { H5 - Dimensionar circuitos ou dispositivos } \\
\text { elétricos de uso cotidiano. }\end{array}$ \\
\hline Ação & Aplicação de fórmula \\
\hline
\end{tabular}




\section{ENEM 2013 - QUESTÃO 76}

Aquecedores solares usados em residências têm o objetivo de elevar a temperatura da água até $70{ }^{\circ} \mathrm{C}$. No entanto, a temperatura ideal da água para um banho é de $30^{\circ} \mathrm{C}$. Por isso, deve-se misturar a água aquecida com a água à temperatura ambiente de um outro reservatório, que se encontra a $25^{\circ} \mathrm{C}$. Qual a razão entre a massa de água quente e a massa de água fria na mistura para um banho à temperatura ideal?
a) 0,111 .
b) 0,125 .
c) 0,357 .
d) 0,428 .
e) 0,833 .

\begin{tabular}{|c|c|}
\hline Tema & $\begin{array}{l}\text { Relação entre massas aquecidas por } \\
\text { aquecedores solares. }\end{array}$ \\
\hline Conteúdo 1 & Equilíbrio térmico. \\
\hline $\begin{array}{l}\text { Colocação da } \\
\text { pergunta }\end{array}$ & Clara e relacionada ao contexto, unívoca. \\
\hline $\begin{array}{l}\text { Apresentação das } \\
\text { alternativas }\end{array}$ & $\begin{array}{l}\text { Organizadas em ordem crescente, } \\
\text { respeitando paralelismos. }\end{array}$ \\
\hline Resolução & $\begin{array}{l}Q_{1}+Q_{2}=0 \\
m_{1} \cdot c \cdot(30-70)=m_{2} \cdot c \cdot(30-25) \\
m_{1} / m_{2}=1 / 8 \\
m_{1} / m_{2}=0,125\end{array}$ \\
\hline Avaliação & $\begin{array}{l}\text { Tecnicista. Aplicação da fórmula e cálculo } \\
\text { de um valor que não ajuda o estudante a } \\
\text { tomar uma ação sobre o problema. Talvez a } \\
\text { quantidade de baldes necessária para ter } \\
\text { um banho à temperatura ideal fosse uma } \\
\text { informação mais útil para o cotidiano do } \\
\text { aluno. }\end{array}$ \\
\hline Habilidade & $\begin{array}{l}\text { H18 - Relacionar propriedades físicas, } \\
\text { químicas ou biológicas de produtos, } \\
\text { sistemas ou procedimentos tecnológicos às } \\
\text { finalidades a que se destinam. }\end{array}$ \\
\hline Ação & Aplicação de fórmula \\
\hline
\end{tabular}




\section{ENEM 2013 - QUESTÃO 79}

Em um dia sem vento, ao saltar de um avião, um paraquedista cai verticalmente até atingir a velocidade limite. No instante em que o paraquedas é aberto (instante TA), ocorre a diminuição de sua velocidade de queda. Algum tempo após a abertura do paraquedas, ele passa a ter velocidade de queda constante, que possibilita sua aterrissagem em segurança.

Que gráfico representa a força resultante sobre o paraquedista, durante o seu movimento de queda?

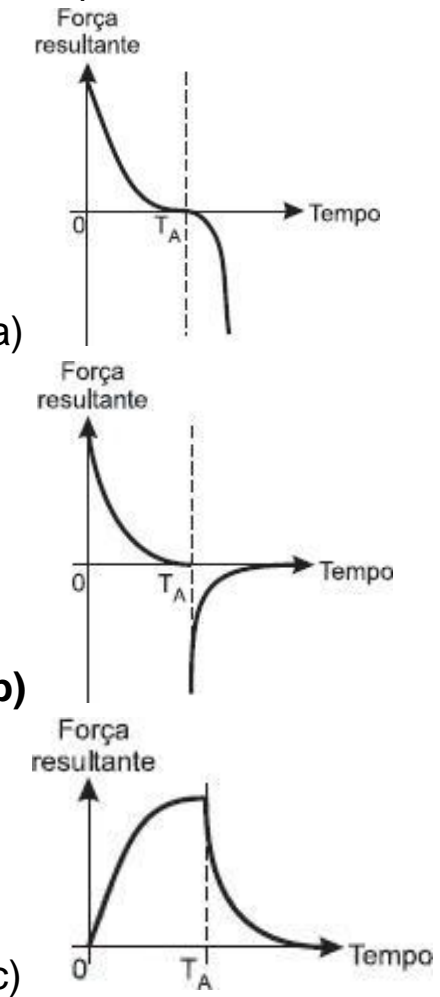

C)

$$
\text { Força }
$$

resultante

d)

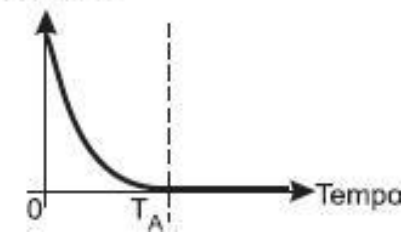

Força

resultante

e)

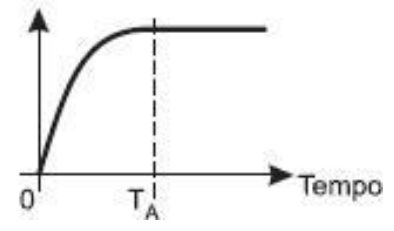

\begin{tabular}{|c|c|}
\hline Tema & $\begin{array}{l}\text { Determinar comportamento de um corpo em } \\
\text { queda na atmosfera }\end{array}$ \\
\hline Conteúdo 1 & Segunda lei de Newton \\
\hline $\begin{array}{l}\text { Colocação da } \\
\text { pergunta }\end{array}$ & Clara e relacionada ao contexto. \\
\hline Resolução & $\begin{array}{l}\text { Quando o paraquedista salta a força peso é } \\
\text { maior do que a força de resistência de forma } \\
\text { que a resultante acelera seu corpo para } \\
\text { baixo. Com o aumento da velocidade a força } \\
\text { de resistência cresce até se igualar com a } \\
\text { força peso fazendo com que a resultante se } \\
\text { anule e o paraquedista atinja a velocidade } \\
\text { máxima possível ou velocidade terminal. } \\
\text { Dessa forma a primeira parte do gráfico é } \\
\text { uma curva decrescente. Ao abrir o } \\
\text { paraquedas a área de contato com o ar } \\
\text { aumenta subtamente, como a força de } \\
\text { resistência depende também da área de } \\
\text { contato o módulo dessa força aumenta } \\
\text { também subtamente freando o } \\
\text { paraquedista. Ao diminuir a velocidade de } \\
\text { queda também reduz o módulo da força de } \\
\text { resistência até que ela novamente se iguale } \\
\text { ao peso e o paraquedista desce sem } \\
\text { aceleração, mas com velocidade reduzida. } \\
\text { Dessa forma a segunda parte do gráfico é } \\
\text { uma curva crescente do negativo até zero. }\end{array}$ \\
\hline Avaliação & $\begin{array}{l}\text { Interpretativa. O estudante deve utilizar os } \\
\text { conceitos das leis de Newton (em especial a } \\
\text { segunda lei) para interpretar a situação e os } \\
\text { gráficos selecionando a alternativa } \\
\text { adequada e que forneça uma interpretação } \\
\text { correta para a situação. }\end{array}$ \\
\hline Habilidade & $\begin{array}{l}\text { H17 - Relacionar informações apresentadas } \\
\text { em diferentes formas de linguagem e } \\
\text { representação usadas nas ciências físicas, } \\
\text { químicas ou biológicas, como texto } \\
\text { discursivo, gráficos, tabelas, relações } \\
\text { matemáticas ou linguagem simbólica. }\end{array}$ \\
\hline Ação & Utilização de esquema \\
\hline
\end{tabular}




\section{ENEM 2013 - QUESTÃO 81}

O chuveiro elétrico é um dispositivo capaz de transformar energia elétrica em energia térmica, o que possibilita a elevação da temperatura da água. Um chuveiro projetado para funcionar em $110 \mathrm{~V}$ pode ser adaptado para funcionar em $220 \mathrm{~V}$, de modo a manter inalterada sua potência.

Uma das maneiras de fazer essa adaptação é trocar a resistência do chuveiro por outra, de mesmo material e com o(a)

a) dobro do comprimento do fio.

b) metade do comprimento do fio.

c) metade da área da seção reta do fio.

d) quádruplo da área da seção reta do fio.

e) quarta parte da área da seção reta do fio.

\begin{tabular}{|c|c|}
\hline Tema & Adaptação em circuito \\
\hline Conteúdo 1 & Resistores \\
\hline Conteúdo 2 & Potencia elétrica \\
\hline $\begin{array}{l}\text { Colocação da } \\
\text { pergunta }\end{array}$ & Clara, relacionada à situação, unívoca. \\
\hline $\begin{array}{l}\text { Apresentação das } \\
\text { alternativas }\end{array}$ & $\begin{array}{l}\text { Obedecem ordenação por extensão. } \\
\text { Poderiam ter artigo incorporado. }\end{array}$ \\
\hline Resolução & $\begin{array}{l}\text { A partir da expressão } \mathrm{P}=\mathrm{U}^{2} / \mathrm{R} \text {. } \mathrm{O} \text { aluno deve } \\
\text { perceber que ao dobrar a tensão, para } \\
\text { manter a mesma potencia deve-se } \\
\text { quadrubplicar a resistência, a partir de } \\
\mathrm{R}=\rho \mathrm{L} / \mathrm{A}\end{array}$ \\
\hline Avaliação & $\begin{array}{l}\text { Tecnicista/Prática. O aluno deve fazer uso } \\
\text { correto das fórmulas que definem a relação } \\
\text { entre os resistores do chuveiro, contudo no } \\
\text { contexto, o resultado pode gerar uma ação } \\
\text { prática como a decisão de qual fio utilizar } \\
\text { para a substituição do resistor. }\end{array}$ \\
\hline Habilidade & $\begin{array}{l}\text { H5 - Dimensionar circuitos ou dispositivos } \\
\text { elétricos de uso cotidiano. }\end{array}$ \\
\hline Ação & Utilização de esquemas \\
\hline
\end{tabular}




\section{ENEM 2013 - QUESTÃO 82}

Uma pessoa necessita da força de atrito em seus pés para se deslocar sobre uma superfície. Logo, uma pessoa que sobe uma rampa em linha reta será auxiliada pela força de atrito exercida pelo chão em seus pés.

Em relação ao movimento dessa pessoa, quais são a direção e o sentido da força de atrito mencionada no texto?

a) Perpendicular ao plano e no mesmo sentido do movimento.

b) Paralelo ao plano e no sentido contrário ao movimento.

c) Paralelo ao plano e no mesmo sentido do movimento.

d) Horizontal e no mesmo sentido do movimento.

e) Vertical e sentido para cima.

\begin{tabular}{|c|c|}
\hline Tema & Movimento de corpo com atrito \\
\hline Conteúdo 1 & Força de atrito \\
\hline Conteúdo 2 & Plano inclinado \\
\hline $\begin{array}{l}\text { Colocação da } \\
\text { pergunta }\end{array}$ & Clara, relacionada à situação, unívoca. \\
\hline $\begin{array}{l}\text { Apresentação das } \\
\text { alternativas }\end{array}$ & $\begin{array}{l}\text { Obedecem ordenação decrescente por } \\
\text { extensão. Apresentam paralelismos. }\end{array}$ \\
\hline Resolução & $\begin{array}{l}\text { A força de atrito deve agir paralelamente ao } \\
\text { plano e fazendo com que o homem suba a } \\
\text { rampa, portanto no mesmo sentido do } \\
\text { movimento. }\end{array}$ \\
\hline Avaliação & $\begin{array}{l}\text { Interpretativo/tecnicista. Embora o } \\
\text { exercício pareça destacar a interpretação do } \\
\text { movimento, faz uso de um problema } \\
\text { canônico que basicamente recorre à } \\
\text { memória do estudante, não na utilização de } \\
\text { fórmulas, mas na aplicação do vetor força. } \\
\text { Estimula a interpretação de fenômenos de } \\
\text { forma científica, mas o faz com o uso de } \\
\text { problema clássico que não exige grande } \\
\text { raciocínio. }\end{array}$ \\
\hline Habilidade & $\begin{array}{l}\text { H17 - Relacionar informações apresentadas } \\
\text { em diferentes formas de linguagem e } \\
\text { representação usadas nas ciências físicas, } \\
\text { químicas ou biológicas, como texto } \\
\text { discursivo, gráficos, tabelas, relações } \\
\text { matemáticas ou linguagem simbólica. }\end{array}$ \\
\hline Ação & Reprodução de conceito \\
\hline
\end{tabular}




\section{ENEM 2013 - QUESTÃO 84}

Medir temperatura é fundamental em muitas aplicações, e apresentar a leitura em mostradores digitais é bastante prático. O seu funcionamento é baseado na correspondência entre valores de temperatura e de diferença de potencial elétrico. Por exemplo, podemos usar o circuito elétrico apresentado, no qual o elemento sensor de temperatura ocupa um dos braços do circuito (RS) e a dependência da resistência com a temperatura é conhecida.

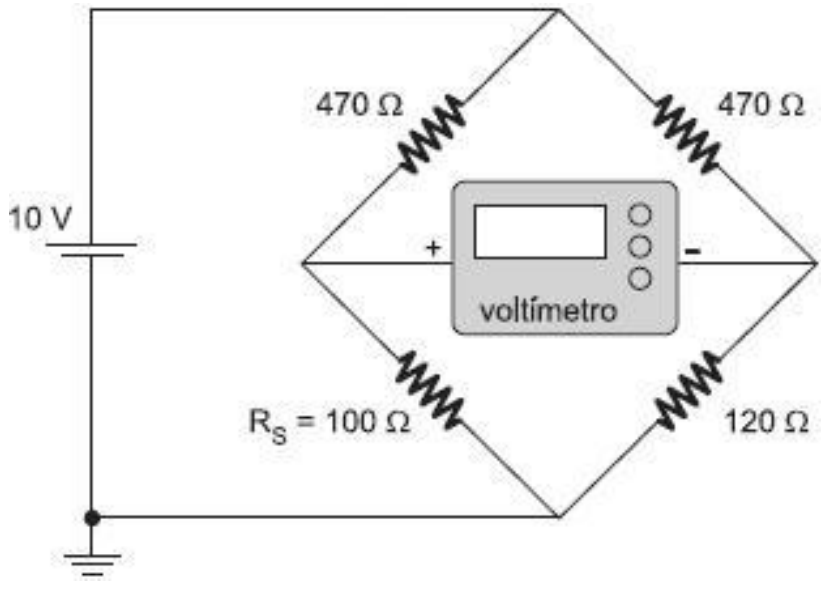

Para um valor de temperatura em que $\mathrm{RS}=100$ $\Omega$, a leitura apresentada pelo voltímetro será de
a) $+6,2 \mathrm{~V}$.
b) $+1,7 \mathrm{~V}$.
c) $+0,3 \mathrm{~V}$.
d) $-0,3 \mathrm{~V}$
e) $-6,2 \mathrm{~V}$.

\begin{tabular}{|l|l|}
\hline Tema & Controle elétrico de temperatura \\
\hline Conteúdo 1 & Ligações de circuitos \\
\hline Conteúdo 2 & Lei de ohm \\
\hline $\begin{array}{l}\text { Colocação da } \\
\text { pergunta }\end{array}$ & $\begin{array}{l}\text { A temperatura aparece como pretexto para } \\
\text { o cálculo de um circuito complicado. }\end{array}$ \\
\hline $\begin{array}{l}\text { Apresentação das } \\
\text { alternativas }\end{array}$ & $\begin{array}{l}\text { Ordem decrescente. Alternativas com } \\
\text { pegadinhas. }\end{array}$ \\
\hline Resolução & $\begin{array}{l}\text { O ramo da direta é o da esquerda estão } \\
\text { com tensão 10V. O ramo da direita tem } \\
\text { resistência equivalente de 590 ohm e pela } \\
\text { lei de ohm ali passa uma corrente de } \\
\text { 0,016A. O ramo da esquerda tem } \\
\text { resistência equivalente de 570 ohm e por ali } \\
\text { passa uma corrente de 0,0017A. Em cada } \\
\text { um dos ramos o primeiro resistor tem valor } \\
\text { de 470ohm para determinar a queda de } \\
\text { tensão em cada um deles utiliza-se a lei de } \\
\text { ohm em cada resistor como a tensão e a } \\
\text { resistência de cada um deles é igual, mas a } \\
\text { corrente é diferente a queda de tensão é } \\
\text { diferente em cada um deles e essa } \\
\text { diferença de -0,3V registrada pelo voltímetro } \\
\text { ligado ao circuito. }\end{array}$ \\
\hline Avabilidade & $\begin{array}{l}\text { Tecnicista. O exercício não tem aplicação } \\
\text { cotidiana, talvez o tenha para algum técnico } \\
\text { especialista, contudo a apresentação do } \\
\text { problema é confusa, já que a medição de } \\
\text { temperatura a partir da voltagem não é nem } \\
\text { propriamente explicada no exercício e nem } \\
\text { necessária na resolução. A função do } \\
\text { elemento sensor R(s) também não é } \\
\text { explicada. O exercício exige que o aluno } \\
\text { saiba aplicar a lei de ohm em um circuito } \\
\text { complexo, mas não contribui para aprimorar } \\
\text { a visão do aluno a respeito do mundo e da } \\
\text { ciência. Existe uma suposta aplicação } \\
\text { cotidiana em relação à medição de } \\
\text { temperatura, mas a resolução do exercício e } \\
\text { a resposta encontrada não fazem parte do } \\
\text { cotidiano da maioria dos alunos. }\end{array}$ \\
\hline $\begin{array}{l}\text { H5 - Dimensionar circuitos ou dispositivos } \\
\text { elétricos de uso cotidiano. }\end{array}$ \\
Aplicação de fórmula \\
\hline Avano
\end{tabular}




\section{ENEM 2013 - QUESTÃO 87}

Um circuito em série é formado por uma pilha, uma lâmpada incandescente e uma chave interruptora. Ao se ligar a chave, a lâmpada acende quase instantaneamente, irradiando calor e luz.

Popularmente, associa-se o fenômeno da irradiação de energia a um desgaste da corrente elétrica, ao atravessar o filamento da lâmpada, e à rapidez com que a lâmpada começa a brilhar. Essa explicação está em desacordo com o modelo clássico de corrente.

De acordo com o modelo mencionado, o fato de a lâmpada acender quase instantaneamente está relacionado à rapidez com que

a) o fluido elétrico se desloca no circuito.

b) as cargas negativas móveis atravessam o circuito.

c) a bateria libera cargas móveis para o filamento da lâmpada.

d) o campo elétrico se estabelece em todos os pontos do circuito.

e) as cargas positivas e negativas se chocam no filamento da lâmpada.

\begin{tabular}{|c|c|}
\hline Tema & $\begin{array}{l}\text { Estabelecimento de campo elétrico em um } \\
\text { circuito. }\end{array}$ \\
\hline Conteúdo 1 & Circuito simples. \\
\hline Conteúdo 2 & Campo elétrico. \\
\hline $\begin{array}{l}\text { Colocação da } \\
\text { pergunta }\end{array}$ & $\begin{array}{l}\text { São apresentados dois modelos, não é } \\
\text { possível ter certeza sobre qual deles o } \\
\text { exercício se refere embora seja possível } \\
\text { deduzir que refere-se ao modelo clássico, já } \\
\text { que é ao único que se refere como modelo. }\end{array}$ \\
\hline $\begin{array}{l}\text { Apresentação das } \\
\text { alternativas }\end{array}$ & $\begin{array}{l}\text { Não obedece ordenação. Pequena quebra } \\
\text { de paralelismo sintático alternativa c. }\end{array}$ \\
\hline Resolução & $\begin{array}{l}\text { Ao ligar o interruptor, estabelece-se entre as } \\
\text { extremidades do fio uma diferença de } \\
\text { potencial que gera um campo elétrico que } \\
\text { vai agir sobre todas as cargas ao longo do } \\
\text { fio. Dessa forma, não é preciso que cargas } \\
\text { saiam do interruptor e sigam até a lâmpada, } \\
\text { mas as cargas que já estão na lâmpada } \\
\text { assumem descolamento ordenado devido } \\
\text { ao campo elétrico agindo também ali, por } \\
\text { isso a impressão de acendimento } \\
\text { instantâneo da lâmpada. }\end{array}$ \\
\hline Avaliação & $\begin{array}{l}\text { Técnico/interpretativa. O aluno deve } \\
\text { compreender o modelo científico do campo } \\
\text { elétrico em circuitos. Contudo essa } \\
\text { interpretação não trás elementos práticos } \\
\text { que permitam que o aluno, ou mesmo um } \\
\text { especialista tome decisões práticas, } \\
\text { somente para ter uma explicação } \\
\text { cientificamente adequada do fenômeno. }\end{array}$ \\
\hline Habilidade & $\begin{array}{l}\text { H3 - Confrontar interpretações científicas } \\
\text { com interpretações baseadas no senso } \\
\text { comum, ao longo do tempo ou em diferentes } \\
\text { culturas. }\end{array}$ \\
\hline Ação & Reprodução de conceitos \\
\hline
\end{tabular}




\section{ENEM 2013 - QUESTÃO 90}

Em um piano, o Dó central e a próxima nota Dó (Dó maior) apresentam sons parecidos, mas não

idênticos. É possível utilizar programas computacionais para expressar o formato dessas ondas sonoras em cada uma das situações como apresentado nas figuras, em que estão indicados intervalos de tempo idênticos $(T)$.

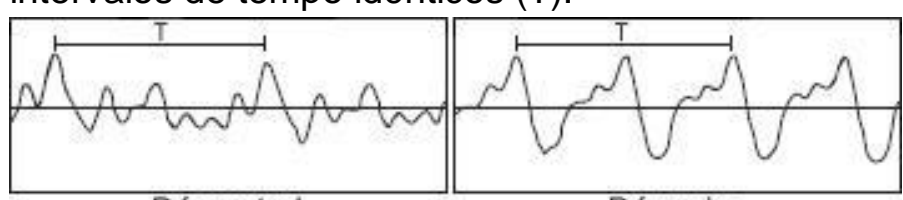

Dó central

Dó maior

\section{A razão entre as frequências do Dó central e do}

Dó maior é de:
a) $1 / 2$.
b) 2 .
c) 1 .
d) $1 / 4$
e) 4 .

\begin{tabular}{|c|c|}
\hline Tema & Frequência de notas musicais \\
\hline Conteúdo 1 & Acústica \\
\hline Conteúdo 2 & Propriedades de ondas \\
\hline $\begin{array}{l}\text { Colocação da } \\
\text { pergunta }\end{array}$ & $\begin{array}{l}\text { A pergunta é clara, mas a construção não } \\
\text { tem gancho sintático com as alternativas. }\end{array}$ \\
\hline $\begin{array}{l}\text { Apresentação das } \\
\text { alternativas }\end{array}$ & A ordenação é por algarismo. \\
\hline Resolução & $\begin{array}{l}\text { No primeiro gráfico o intervalo de tempo } \\
\text { indicado abarca um comprimento de onda. } \\
\text { No segundo gráfico são abarcados dois } \\
\text { comprimentos de onda. Isso indica que } \\
\text { houve um aumento de duas vezes na } \\
\text { frequência do primeiro em relação ao } \\
\text { segundo gráfico. }\end{array}$ \\
\hline Avaliação & $\begin{array}{l}\text { Tecnicista. O contexto poderia ser } \\
\text { qualquer, e não é relevante para a } \\
\text { resolução do problema. Nem mesmo os } \\
\text { eixos são nomeados o que torna o foco do } \\
\text { exercício bem mais vago, podendo as } \\
\text { oscilações apresentadas referir-se a } \\
\text { qualquer coisa. O item testa apenas a } \\
\text { capacidade do aluno de reconhecer um } \\
\text { padrão ondulatório e aplicar a equação que } \\
\text { relaciona velocidade de uma onda } \\
\text { comprimento de onda e frequência. Não é } \\
\text { relevante para o cotidiano do aluno e } \\
\text { dificilmente o faz refletir sobre sua visão de } \\
\text { mundo e de ciência. }\end{array}$ \\
\hline Habilidade & $\begin{array}{l}\text { H01- Reconhecer características ou } \\
\text { propriedades de fenômenos ondulatórios ou } \\
\text { oscilatórios, relacionando-os a seus usos } \\
\text { em diferentes contextos. }\end{array}$ \\
\hline Ação & Aplicação de fórmula \\
\hline
\end{tabular}




\section{APÊNDICE B - QUESTIONÁRIO UTILIZADO \\ O Ensino e o desenvolvimento de competências}

Em pesquisa que está sendo realizada junto ao Programa de Pós Graduação Interunidades em Ensino de Ciências, estamos investigando a relação de professores e professoras com a atuação por competências. Embora essa seja uma orientação

presente na legislação, tudo indica que há muitos problemas para sua efetiva implementação em sala de aula. Gostaríamos de pedir sua colaboração, respondendo às perguntas a seguir.

Obrigado!

Em qual(is) disciplina(s) possui formação?

$\square$ Biologia $\square$ Química $\square$ Física $\square$

Matemática

Qual(is) disciplina(s) leciona atualmente?

$\square$ Biologia $\square$ Química $\square$ Física $\square$

Matemática

Há quanto tempo leciona a(s) disciplina(s) mencionada(s) na questão acima?

Em qual tipo de escola leciona? $\square$ Pública $\square$ Particular $\square$ As duas $\square$ Outra:

\section{I - EM QUE CONSISTE O ENSINO-APRENDIZAGEM POR COMPETÊNCIAS?}

A. Quais elementos indicariam a ênfase em competências (e não apenas nos conteúdos) no processo de ensino-aprendizagem?

B. Os objetivos de um ensino tradicional, afinal, são os mesmos de um ensino por competências? 
C. Abaixo são apresentados alguns elementos a respeito do processo de ensinoaprendizagem. Circule o número que classifica cada elemento de acordo com sua importância para o desenvolvimento de competências, sendo que:

1- Nenhuma importância; 2- Pode ser usado, mas é dispensável;

3- É recomendado, mas não essencial; 4- É essencial para trabalhar com competências.

\begin{tabular}{|llll|l|}
\hline 1 & 2 & 3 & 4 & Experimentação. \\
\hline 1 & 2 & 3 & 4 & Contexto \\
\hline 1 & 2 & 3 & 4 & Interdisciplinaridade. \\
\hline 1 & 2 & 3 & 4 & Provas dissertativas. \\
\hline 1 & 2 & 3 & 4 & Aprender a aprender \\
\hline 1 & 2 & 3 & 4 & Debates \\
\hline 1 & 2 & 3 & 4 & Mobilizar recursos para resolver um problema. \\
\hline 1 & 2 & 3 & 4 & Projetos \\
\hline 1 & 2 & 3 & 4 & Seminários em grupo \\
\hline 1 & 2 & 3 & 4 & Relevância social. \\
\hline 1 & 2 & 3 & 4 & Outros: \\
\hline
\end{tabular}

\section{II - IDENTIFICANDO COMPETÊNCIAS}

Diante de intenções de uma avaliação por competências, analise a questão apresentada abaixo, (não é preciso resolvê-la)

O chuveiro elétrico é um dispositivo capaz de transformar energia elétrica em energia térmica, o que possibilita a elevação da temperatura da água. Um chuveiro projetado para funcionar em $110 \mathrm{~V}$ pode ser adaptado para funcionar em $220 \mathrm{~V}$, de modo a manter inalterada sua potência.

Uma das maneiras de fazer essa adaptação é trocar a resistência do chuveiro por outra, de mesmo material e com o(a)

a) dobro do comprimento do fio.

b) metade do comprimento do fio.

c) metade da área da seção reta do fio.

d) quádruplo da área da seção reta do fio.

e) quarta parte da área da seção reta do fio.

Você considera que essa questão avalia o aluno do ponto de vista de competências? Qual(is) elemento(s) justifica(m) sua resposta? 


\section{COMPETÊNCIAS NA ATIVIDADE DOS PROFESSORES}

A. Em sua experiência como docente, quais contatos você já teve com coisas/situações nas quais havia elementos que apontavam para um ensino por competências?

$\square$ Em escola onde trabalhou $\square$ No livro didático que adotou $\square$ Em material didático que usou $\square$ Outros:

$\square$ Nunca me deparei com coisas/situações

do tipo.

B. Você já trabalhou por competências? As escolas em que atuou sinalizavam para um efetivo trabalho nessa direção? Já recebeu/encontrou orientação específica sobre como fazer isso? Valeria a pena? O que contribui para que professores e professoras trabalhem por competências? O que é um empecilho?

\section{OUTROS COMENTÁRIOS OU OBSERVAÇÕES SOBRE ESSE ASSUNTO}

Se quiser entrar em contato ou tiver interesse nos resultados dessa pesquisa, envie um e-mail para samuel.paiva@usp.br com o assunto PESQUISA SOBRE COMPETÉNCIAS. Teremos prazer em conversar e/ou compartilhar. 


\section{APÊNDICE C - TABULAÇÃO DAS PRINCIPAIS RESPOSTAS \\ Os professores e o desenvolvimento de competências - Julho 2017 - USP/Escola}

\section{I - EM QUE CONSISTE O ENSINO-APRENDIZAGEM POR COMPETÊNCIAS?}

A. Quais elementos indicariam a ênfase em competências (e não apenas nos conteúdos) no processo de ensino-aprendizagem?

B. Os objetivos de um ensino tradicional, afinal, são os mesmos de um ensino por competências?

\begin{tabular}{|c|c|c|c|}
\hline Curso & Anos & A & B \\
\hline Q1 & 3 & $\begin{array}{l}\text { Fazer o aluno interpretar dados, indo } \\
\text { além do conteúdo, buscando } \\
\text { interdisciplinaridade, transitar entre } \\
\text { informações, raciocínio. }\end{array}$ & $\begin{array}{l}\text { NÃO, pois o ensino tradicional está } \\
\text { baseado no conteúdo, como se o } \\
\text { aluno tivesse que "absorver" toda } \\
\text { informação, sem necessidade de } \\
\text { desenvolver/trabalhar as } \\
\text { competências que estes alunos } \\
\text { possuem. O ensino por competência } \\
\text { buscam desenvolver consciência e } \\
\text { trabalhar/organizar suas ideias. }\end{array}$ \\
\hline Q2 & 33 & $\begin{array}{l}\text { - desenvolvimento cognitivo. } \\
\text { - desenvolvimento da autonomia. }\end{array}$ & $\begin{array}{l}\text { NÃO, no tradicional passavam } \\
\text { conteúdos, por competências iremos } \\
\text { desenvolver habilidades para } \\
\text { resolucão de problemas. }\end{array}$ \\
\hline Q3 & 5 & & $\begin{array}{l}\text { Acho que o Ensino de Competências } \\
\text { nos dá uma oportunidade de discutir } \\
\text { um ensino de química mais reflexivo } \\
\text { e que discuta uma abordagem social } \\
\text { do ensino. }\end{array}$ \\
\hline $\mathrm{Q} 4$ & 16 & $\begin{array}{l}\text { Atividades que possibilitem o } \\
\text { desenvolvimento do pensamento crítico, } \\
\text { autonomia, extrapolação do raciocínio. }\end{array}$ & $\begin{array}{l}\text { NÂO, pois deixam a cargo do } \\
\text { estudante o desenvolvimento de } \\
\text { competências }\end{array}$ \\
\hline Q5 & 10 & $\begin{array}{l}\text { Competência cognitiva, capacidade de } \\
\text { aprendizagem o qual estão relacionados } \\
\text { com o rendimento escolar. }\end{array}$ & $\begin{array}{l}\text { NÃO. No ensino tradicional o } \\
\text { conteúdo já vem pronto. Cabe ao } \\
\text { aluno memorizar o que foi proposto. } \\
\text { Já o ensino por competência tem } \\
\text { como por objetivo analisar o } \\
\text { processo, o qual contribui de forma } \\
\text { significativa para a formação integral } \\
\text { do aluno em todas suas dimensões. }\end{array}$ \\
\hline Q6 & 25 & $\begin{array}{l}\text { ao pensamento do aluno, percepção, } \\
\text { raciocínio, interação. }\end{array}$ & $\begin{array}{l}\text { NÃO são os mesmos. No ensino } \\
\text { tradicional o conteúdo já vem pronto } \\
\text { o aluno não participa do processo } \\
\text { ensino-aprendizagem de maneira } \\
\text { efetiva. }\end{array}$ \\
\hline Q7 & 10 & $\begin{array}{l}\text { Identificar, relacionar, pensamento e } \\
\text { conhecimento prévio e raciocínio. }\end{array}$ & $\begin{array}{l}\text { NÃO. O tradicional está relacionado } \\
\text { com a memorização. }\end{array}$ \\
\hline $\mathrm{Q} 8$ & 16 & $\begin{array}{l}\text { Desenvolvimento cognitivo do aluno } \\
\text { considerando sua leitura do mundo. }\end{array}$ & $\begin{array}{l}\text { NÂO, o ensino tradicional é } \\
\text { conteudista. }\end{array}$ \\
\hline Q9 & 7 & $\begin{array}{l}\text { Pensar, aprender, autonomia, senso } \\
\text { crítico }\end{array}$ & $\begin{array}{l}\text { NÃO. O foco é desenvolver } \\
\text { habilidades cognitivas. }\end{array}$ \\
\hline Q10 & 2,5 & $\begin{array}{l}\text { Processos cognitivos, relações de } \\
\text { causa e efeito. }\end{array}$ & $\begin{array}{l}\text { NÃO. O ensino tradicional preconiza } \\
\text { mera memorização, enquanto o } \\
\text { ensino por competências prioriza } \\
\text { processos cognitivos. }\end{array}$ \\
\hline Q11 & 5 & $\begin{array}{l}\text { Acredito que a ênfase seja dada a } \\
\text { medida que o aluno reproduz os }\end{array}$ & $\begin{array}{l}\text { NÃO, pois tanto no ensino } \\
\text { tradicional quanto no ensino por }\end{array}$ \\
\hline
\end{tabular}




\begin{tabular}{|c|c|c|c|}
\hline & & conhecimentos construídos. & $\begin{array}{l}\text { competências, o professor deve } \\
\text { adaptar sua forma de abordagem } \\
\text { conforme as necessidades das } \\
\text { turmas trabalhadas. }\end{array}$ \\
\hline Q12 & 25 & $\begin{array}{l}\text { Planejar a atividade pedagógica. } \\
\text { Realizar atividades onde os alunos } \\
\text { podem coletar dados através de } \\
\text { observações para ao final do processo o } \\
\text { aluno possa elaborar conclusões. }\end{array}$ & Não. \\
\hline Q13 & 15 & $\begin{array}{l}\text { O ensino em competências permite um } \\
\text { planejamento e um replanejamento } \\
\text { baseado na realidade ou seja, você } \\
\text { consegue desenvolver um aluno mais } \\
\text { reflexivo, autônomo, consciente do seu } \\
\text { papel na sociedade. }\end{array}$ & $\begin{array}{l}\text { Não, no ensino tradicional temos a } \\
\text { "aula bancária" onde há depósito de } \\
\text { conteúdos sem a responsabilidade } \\
\text { de desenvolver um aluno com } \\
\text { competências cognitivas. }\end{array}$ \\
\hline Q14 & 2 & $\begin{array}{l}\text { Observação, descrição, compreensão, } \\
\text { são elementos fundamentais na busca } \\
\text { pelo conhecimento. }\end{array}$ & $\begin{array}{l}\text { Os objetivos do ensino tradicional } \\
\text { auxiliam no ensino por } \\
\text { competências. }\end{array}$ \\
\hline Q15 & 15 & Planejamento das aulas. & Não. \\
\hline Q16 & 15 & $\begin{array}{l}\text { Competência visual (observar). } \\
\text { Estabelecer relações. comparação. }\end{array}$ & $\begin{array}{l}\mathrm{NÃO} \text {, o ensino tradicional o } \\
\text { professor era o detentor do } \\
\text { conhecimento e não permitia } \\
\text { discussão com o aluno. }\end{array}$ \\
\hline Q17 & 6 & $\begin{array}{l}\text { A ação relacionada à aprendizagem, } \\
\text { mobilizando diferentes recursos, sejam } \\
\text { próprios ou aprendidos na escola. }\end{array}$ & $\begin{array}{l}\text { Os objetivos são os mesmos, porém } \\
\text { os processos, procedimentos e as } \\
\text { demandas para os professores, } \\
\text { alunos, pais e gestão escolar são } \\
\text { diferentes como, por exemplo, a } \\
\text { interdisciplinaridade. }\end{array}$ \\
\hline Q18 & 12 & $\begin{array}{l}\text { Atividades experimentais, uso de } \\
\text { aplicativos, observações de situações } \\
\text { cotidianas. }\end{array}$ & $\begin{array}{l}\mathrm{NÃO} \text {, pois o aluno precisa aprender } \\
\text { a fazer associações relacionando } \\
\text { teorias. }\end{array}$ \\
\hline Q19 & 7 & $\begin{array}{l}\text { O ensino centrado no desenvolvimento } \\
\text { do aluno pleno, protagonista, ou seja, } \\
\text { que não prioriza a aprendizagem de } \\
\text { conteúdos isolados. }\end{array}$ & $\begin{array}{l}\text { Não, o tradicional valoriza a } \\
\text { memorização de conteúdos apenas. }\end{array}$ \\
\hline Q20 & 24 & $\begin{array}{l}\text { Acho que torna o aluno um pensador, } \\
\text { ele se torna o protagonista do ensino } \\
\text { aprendizagem. O aluno tem que } \\
\text { pensar/analisar/contextualizar/criar } \\
\text { hipótese/ resolver questões. }\end{array}$ & $\begin{array}{l}\text { NÃO. O ensino tradicional é } \\
\text { conteudista. }\end{array}$ \\
\hline Q21 & 0,5 & $\begin{array}{l}\text { Desenvolvimento do pensamento } \\
\text { crítico, autônomo, raciocínio lógico. }\end{array}$ & $\begin{array}{l}\text { Considero que NÃO. O ensino } \\
\text { tradicional possui como ênfase o } \\
\text { desenvolvimento de determinados } \\
\text { conteúdos considerados pertinentes } \\
\text { e tais conteúdos delimitaram as } \\
\text { atividades que são trabalhadas em } \\
\text { aula. Já no ensino por competência } \\
\text { têm-se a definição das } \\
\text { competências e habilidades que se } \\
\text { deseja trabalhar, e a partir daí } \\
\text { determina-se os conteúdos que } \\
\text { possam desenvolver tais } \\
\text { competências. }\end{array}$ \\
\hline Q22 & 15 & $\begin{array}{l}\text { Preocupação com desenvolvimento do } \\
\text { aluno, desenvolvimento de atividades } \\
\text { que sejam desenvolvidas em sua maior } \\
\text { parte pelos aluno com a orientação e } \\
\text { direcionamento do professor. }\end{array}$ & $\begin{array}{l}\text { De certa forma SIM, pois em ambos } \\
\text { busca-se desenvolver determinado } \\
\text { conteúdo. No entanto, no ensino } \\
\text { tradicional o conteúdo é um fim em } \\
\text { si mesmo, já no ensino por } \\
\text { competências, se busca atingir o }\end{array}$ \\
\hline
\end{tabular}




\begin{tabular}{|l|c|l|l|}
\hline & & & $\begin{array}{l}\text { conteúdo por meio do } \\
\text { desenvolvimento de competências e } \\
\text { habilidades. }\end{array}$ \\
\hline Q23 & 7 & $\begin{array}{l}\text { Utilização de experimentos onde o } \\
\text { aluno tem que ser um pesquisador e } \\
\text { não apenas um seguidor de roteiro, } \\
\text { perguntas abertas com justificativas que } \\
\text { exijam raciocínio e conhecimento fora. }\end{array}$ & $\begin{array}{l}\text { Um objetivo do ensino tradicional é } \\
\text { aprendizagem do conteúdo pelo } \\
\text { conteúdo onde nem sempre se leva } \\
\text { em consideração habilidades e } \\
\text { competências. }\end{array}$ \\
\hline Q24 & 8 & $\begin{array}{l}\text { - Leituras de gráficos e tabelas. } \\
\text { - resolução de exercícios }\end{array}$ & NÃO. \\
\hline Q25 & 1,5 & & $\begin{array}{l}\text { Acredito que NÃO, pois no ensino } \\
\text { tradicional ainda é valorizada a } \\
\text { aprendizagem dos conteúdos e não } \\
\text { há uma valorização do } \\
\text { questionamento/resolução de } \\
\text { problemas. }\end{array}$ \\
\hline Q26 & 20 & $\begin{array}{l}\text { Ensino que faz sentido para o aluno. } \\
\text { fazer previsões e elaborar hipóteses } \\
\text { sobre determinado assunto. }\end{array}$ & $\begin{array}{l}\text { Não, O ensino tradicional é passar o } \\
\text { maior número de informações, não } \\
\text { significa se competente. }\end{array}$ \\
\hline Q27 & 2 & $\begin{array}{l}\text { A construção de um raciocínio } \\
\text { independente de intervenções. }\end{array}$ & Acho que NÂO. \\
\hline Q28 & 20 & $\begin{array}{l}\text { Planejamento/Forma de avaliar. } \\
\text { Naño. }\end{array}$ & NÂO. \\
\hline
\end{tabular}

\begin{tabular}{|c|c|c|c|}
\hline Curso & Anos & A & B \\
\hline RR1 & 20 & $\begin{array}{l}\text { Interpretação do resultado, } \\
\text { interpretação das situações-problema } \\
\text { apresentadas, aplicação do } \\
\text { conhecimento /da competência } \\
\text { adquirido(a), expressão oral/escrita } \\
\text { compreensível do conhecimento } \\
\text { adquirido, interpretação de situações } \\
\text { experimentais e seus resultados } \\
\text { expressão oral/escrita compreensível } \\
\text { de atividades experimentais. }\end{array}$ & NÃO. \\
\hline RR2 & 30 & $\begin{array}{l}\text { Competências são, na realidade, aquilo } \\
\text { que o aluno aprende com determinadas } \\
\text { situações de aprendizagem prática }\end{array}$ & $\begin{array}{l}\text { As competências tem (possuem) os } \\
\text { igredientes do cotidiano, dos hábitos } \\
\text { de vida ou mesmo cultura. }\end{array}$ \\
\hline RR3 & 18 & $\begin{array}{l}\text { O conhecimento de fenômenos naturais } \\
\text { e saber relacionar leis e teorias a estes } \\
\text { fenômenos. }\end{array}$ & $\begin{array}{l}\text { Entendo que alguns objetivos de um } \\
\text { ensino tradicional estejam inseridos } \\
\text { no ensino por competências (P.E. } \\
\text { resolução de exercícios) }\end{array}$ \\
\hline RR4 & & Pesquisa; leitura e Contextualização & Sim, serve como parâmetro. \\
\hline RR5 & 13 & $\begin{array}{l}\text { Atividades em grupo, projetos de } \\
\text { pesquisa experiências }\end{array}$ & Não \\
\hline RR6 & 8 & $\begin{array}{l}\text { A interpretação do enunciado, } \\
\text { compreender e elaborar relações das } \\
\text { Leis da Física. }\end{array}$ & $\begin{array}{l}\text { Se for para formar um cidadão crítico } \\
\text { sim, mas depende muito se o aluno } \\
\text { atingiu as habilidades necessárias } \\
\text { para sua competência. }\end{array}$ \\
\hline RR7 & 7 & $\begin{array}{l}\text { A não utilização apenas de problemas } \\
\text { de resolução de contas, exercícios de } \\
\text { caráter objetivo apenas. }\end{array}$ & $\begin{array}{l}\text { Ambos querem ensinar Física, pelo } \\
\text { menos se propõe a isso, contudo a } \\
\text { formação final é completamente } \\
\text { diferente. }\end{array}$ \\
\hline RR8 & 3 & $\begin{array}{l}\text { Resolução organização de informações } \\
\text { e tomadas de decisões. }\end{array}$ & $\begin{array}{l}\text { Teoricamente sim, espera que os } \\
\text { alunos atinjam tal. }\end{array}$ \\
\hline RR9 & 16 & $\begin{array}{l}\text { Deixar o aluno concluir e construir os } \\
\text { conceitos baseados na sua realidade } \\
\text { de mundo. }\end{array}$ & $\begin{array}{l}\text { Não, os objetivos do ensino } \\
\text { tradicional vai além das } \\
\text { competências, além de ser muito } \\
\text { extenso e muitos conteúdos. }\end{array}$ \\
\hline
\end{tabular}




\begin{tabular}{|l|c|l|l|}
\hline RR10 & 3 & $\begin{array}{l}\text { Uso de métodos diferenciados ex.: } \\
\text { experiências }\end{array}$ & Não \\
\hline RR11 & 10 & $\begin{array}{l}\text { Ensinar algo através de uma } \\
\text { competência. }\end{array}$ & $\begin{array}{l}\text { Não, o ensino por competências está } \\
\text { relacionado com a maneira de } \\
\text { abordagem. }\end{array}$ \\
\hline RR12 & 3 & $\begin{array}{l}\text { Relações com cotidiano e a vivência do } \\
\text { aluno. Unir conhecimento e prática. }\end{array}$ & Não. \\
\hline
\end{tabular}

\begin{tabular}{|c|c|c|c|}
\hline Curso & Anos & A & B \\
\hline HE1 & 13 & $\begin{array}{l}\text { Desenvolvimento cognitivo para } \\
\text { resolver problemas interdisciplinares e } \\
\text { cotidianos }\end{array}$ & $\begin{array}{l}\text { Não, pois o desenvolvimento de } \\
\text { competências são de aplicação } \\
\text { geral. }\end{array}$ \\
\hline HE2 & 22 & $\begin{array}{l}\text { Utilizar de recursos didáticos e } \\
\text { parcerias voltadas as competências do } \\
\text { aluno. Como a competência a arte a } \\
\text { linguagem e a ciência. }\end{array}$ & $\begin{array}{l}\text { Não, o ensino tradicional não é } \\
\text { levado em consideração a } \\
\text { competência você padroniza as } \\
\text { aptidões. }\end{array}$ \\
\hline HE3 & 3 & $\begin{array}{l}\text { Leitura científica, interpretação } \\
\text { (dados/tabelas/gráficos), investigação } \\
\text { em situações problema. }\end{array}$ & $\begin{array}{l}\text { Os objetivos de um ensino por } \\
\text { competências difere no que diz } \\
\text { respeito a transposição do } \\
\text { conhecimento adquirido para } \\
\text { solução de situações cotidianas. }\end{array}$ \\
\hline HE4 & 10 & $\begin{array}{l}\text { Atitude; isto é, o indivíduo adquire } \\
\text { atitude de estudar. Ele não responde } \\
\text { "mecanicamente", ele busca relacionar } \\
\text { os conhecimentos as habilidades das } \\
\text { áreas para tentar resolver uma situação } \\
\text { problema. }\end{array}$ & $\begin{array}{l}\text { Não. No ensino tradicional o aluno é } \\
\text { avaliado isoladamente dentro de } \\
\text { uma disciplina. Não é considerado } \\
\text { ou aproveitado a interdisciplinaridade } \\
\text { e ou a contextualização do } \\
\text { conhecimento. }\end{array}$ \\
\hline HE5 & 5 & $\begin{array}{l}\text { Capacidade de distinguir fatores, } \\
\text { interpretação e desenvolvimento do } \\
\text { assunto. }\end{array}$ & $\begin{array}{l}\text { Não, no tradicional tínhamos (temos) } \\
\text { uma informação a ser registrada } \\
\text { como importante ou relevante. } \\
\text { Por competência temos que } \\
\text { aprimorar o raciocínio, e integrar o } \\
\text { aluno em um contexto até } \\
\text { interdisciplinar. Procurando } \\
\text { contextualizar o assunto para um } \\
\text { entendimento mais amplo - não } \\
\text { apenas decorar uma fórmula. }\end{array}$ \\
\hline HE6 & 16 & $\begin{array}{l}\text { Conceito abordado - aplicação } \\
\text { estendida (interdisciplinar) }\end{array}$ & $\begin{array}{l}\text { Não - Ensino tradicional -> voltado } \\
\text { para uma finalidade. } \\
\text { Ensino competência -> voltado para } \\
\text { uma formação. }\end{array}$ \\
\hline HE7 & 8 & $\begin{array}{l}\text { Seria um ensino que visa uma } \\
\text { formação para a vida, em que a sua } \\
\text { formação permita tomar decisões de } \\
\text { acordo com o momento. }\end{array}$ & $\begin{array}{l}\text { Acredito que não. Não ensino } \\
\text { tradicional busca atender o currículo } \\
\text { ou um projeto específico. }\end{array}$ \\
\hline HE8 & 8 & $\begin{array}{l}\text { Experimentação. Contextualização. } \\
\text { Interdisciplinaridade. Resolução de } \\
\text { situações-problema. }\end{array}$ & $\begin{array}{l}\text { Os mesmos não. O ensino } \\
\text { tradicional busca mais a } \\
\text { memorização e fixação de } \\
\text { conteúdos. O ensino por } \\
\text { competências exige mais, pois além } \\
\text { do domínio do conteúdo, é cobrado a } \\
\text { aplicação destes na resolução de } \\
\text { problemas. }\end{array}$ \\
\hline HE9 & & $\begin{array}{l}\text { Na capacidade de resolver problemas, } \\
\text { habilidades em algumas matérias, } \\
\text { aptidão. }\end{array}$ & Não \\
\hline HE10 & & $\begin{array}{l}\text { A resolução de problemas usando os } \\
\text { conteúdos aprendidos na sala de aula. }\end{array}$ & $\begin{array}{l}\text { Não, o tradicional vai saturar o aluno } \\
\text { com conteúdos sem uma clara } \\
\text { noção ou experimentação desses }\end{array}$ \\
\hline
\end{tabular}




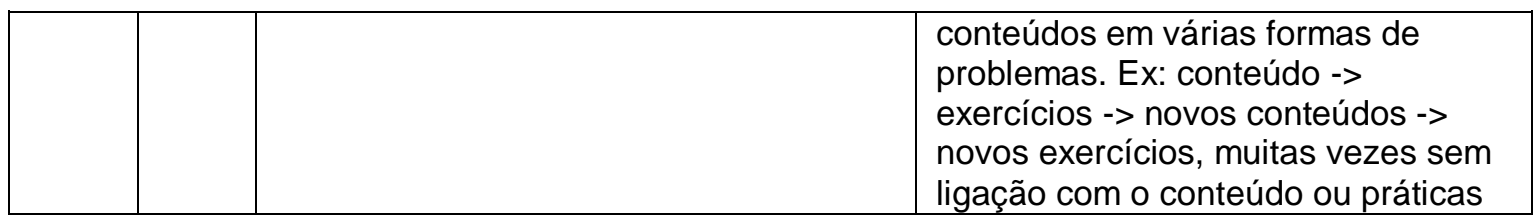

\begin{tabular}{|c|c|c|c|}
\hline Curso & Anos & A & B \\
\hline EXP1 & 10 & & $\begin{array}{l}\text { Não. No ensino tradicional é } \\
\text { conteudista, o professor tem a } \\
\text { preocupação em depositar o } \\
\text { conteúdo sem observar se o aluno } \\
\text { aprender. Por competência o ensino } \\
\text { desenvolve as habilidades do aluno } \\
\text { para enfrentar situações em que ele } \\
\text { consiga resolver. }\end{array}$ \\
\hline EXP2 & 20 & $\begin{array}{l}\text { Competências leitora, escritora, } \\
\text { raciocínio lógico e atitudinais de } \\
\text { convivência e observação. }\end{array}$ & $\begin{array}{l}\text { Depende do direcionamento que o } \\
\text { professor aplica nas aulas e do } \\
\text { planejamento didático. }\end{array}$ \\
\hline EXP3 & 6 & $\begin{array}{l}\text { As habilidades que estão envolvidas } \\
\text { nas competências. }\end{array}$ & $\begin{array}{l}\text { Não o tradicional está gerando } \\
\text { somente conteúdo }\end{array}$ \\
\hline EXP4 & 5 & & Acredito que sim. \\
\hline EXP5 & 8 & $\begin{array}{l}\text { As habilidades envolvidas em cada } \\
\text { uma das competências }\end{array}$ & $\begin{array}{l}\text { Não, o ensino tradicional usa } \\
\text { somente agregar conteúdos. }\end{array}$ \\
\hline EXP6 & 2 & $\begin{array}{l}\text { - Leitura de textos e imagens; } \\
\text { - Elaboração de relatório e respostas. } \\
\text { - Interpretação. } \\
\text { - Experimentos. }\end{array}$ & $\begin{array}{l}\text { Sim, pois para que se alcance o } \\
\text { ensino tradicional o aluno precisa ser } \\
\text { competente para tal, ou seja, as } \\
\text { competências estão inseridas no } \\
\text { processo. }\end{array}$ \\
\hline EXP7 & 3 & $\begin{array}{l}\text { Habilidades envolvidas nas } \\
\text { competências }\end{array}$ & $\begin{array}{l}\text { Não, ensino tradicional é } \\
\text { conteudista. }\end{array}$ \\
\hline EXP8 & 6 & $\begin{array}{l}\text { As habilidades que cada aluno } \\
\text { desenvolve }\end{array}$ & $\begin{array}{l}\text { Não, o ensino tradicional é } \\
\text { conteudista e o por competências vai } \\
\text { aguçando valores e habilidades ao } \\
\text { conhecimento do aluno. }\end{array}$ \\
\hline EXP9 & & $\begin{array}{l}\text { Conhecimento, habilidade e atitude por } \\
\text { meio da experimentação, } \\
\text { interdisciplinaridade, debates etc. }\end{array}$ & $\begin{array}{l}\text { Não, pois o ensino por competências } \\
\text { objetiva não apenas obter } \\
\text { informações e conhecimento, mas } \\
\text { também desenvolver ideias, como } \\
\text { enfrentar problemas e superá-los. }\end{array}$ \\
\hline EXP10 & 33 & Leitura interpretativa & Não \\
\hline EXP11 & 25 & & \\
\hline EXP12 & 10 & & \\
\hline EXP13 & & $\begin{array}{l}\text { Ter competência é aprender algo. } \\
\text { Fazer algo com aquilo que aprendeu é } \\
\text { habilidade. }\end{array}$ & Não \\
\hline EZP14 & 4 & $\begin{array}{l}\text { Competências leitoras e escritora: } \\
\text { interpretação de textos, gráficos, } \\
\text { esquemas, imagens. }\end{array}$ & $\begin{array}{l}\text { Não, geralmente o ensino tradicional } \\
\text { foca os conteúdos a fim da } \\
\text { capacitação do aluno para o } \\
\text { vestibular. }\end{array}$ \\
\hline EXP15 & 10 & $\begin{array}{l}\text { Desenvolver habilidades para chegar } \\
\text { às competências. }\end{array}$ & Não, tradicional trabalhar conteúdos. \\
\hline
\end{tabular}

